




\section{THE}

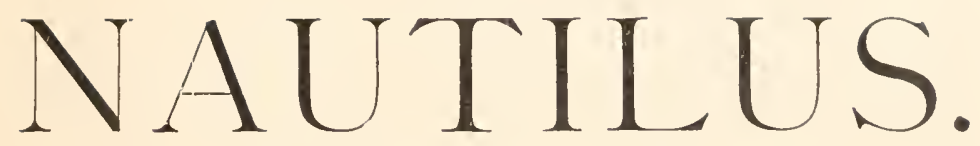

A MONTHLY JOURNAL

DEVOTED TO THE INTERESTS OF

CONCHOLOGISTS.

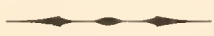

VOL. XI.

MAY, 1897, to APRIL, 1898.

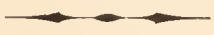

PHILADELPHIA :

Published by II. A. PILSBRY and C. IV. JOHNSON. 



\section{INDEX}

TO

\section{THE NAUTILUS, VOL. XI.}

\section{INDEX TO TITLES AND SPECIES DESCRIBED.}

Achatina Crawfordi Melv. viviparous . . . . . . . 69

Actieon Traskii Stearns, n. sp. . . . . . . . . . . . 14

Ariolimax californicus . . . . . . . . . . . . . . . 76

Ariolimax costaricensis . . . . . . . . . . . . . . 77

Agriolimax, notes on (illustrated) . . . . . . . . . 15

Amphidromus Eudeli Ancey, n. sp. . . . . . . . . . 63

Amphidromus Fultoni Ancey, n. sp. . . . . . . . . . 62

Ampullaria, sinistral . . . . . . . . . . . . . 33

Anomia navicelloides Aldrich, n. sp. (Eocene) . . . . . 87

Bothriopupa Pils. . . . . . . . . . . . . . . . 119

Bolinas, California; The conchologists paradise . . . . 49

Breeding sinistral Helices .. . . . . . . . . . . . 70

"Bulimi" from the Hebrides, on two so-called . . . . . 26

Bullia buccinoitles Merriam, n. sp. (M. Eocene) . . . . 64

Bullia Uruguayensis Pilsbry, n. sp. . . . . . . . . . 6

Callista varians in Florida. . . . . . . . . . . . . 33

Cancellaria annosa Aldrich, n. sp. (Eocene). . . . . . 97

Cancellaria graciloides Aldrich, n. sp. (Eocene) . . . . 98

Cancellaria graciloides var. bella Aldrich, n. var. (Eocene) 98

Cancellaria lanceolata Aldrich, n. sp. (Eocene) . . . . 27

Catalogue of American land shells with localities, 45, 59,

Cathaica Funki Ancey, n. sp. . . . . . . . . . . . 16

Colocentrum astrophorea Dall, n. sp. . . . . . . . 62

Collecting at Ballast Point . . . . . . . . . . . . . 67

Collecting in Monterey Bay . . . . . . . . . . . . 23

Collection of Mollusks from Grand Tower, Illinois . . . 28

Conchological notes from Louisiana . . . . . . . . 3

Coralliophaga, a new subgenus of . . . . . . . . 135 
Cypreidæ, Hawaiian . . . . . . . . . . . . 123

Cyptherea Newcombei Merriam, n. sp. (MI. Neocene). . 64

Cyptherea vancouverensis Merriam, n. sp. (M. Neocene) 64

Diplomorpha ruga and Bernieri . . . . . . . . . . . 26

Editorial correspondence . . . . . . . . . . . 66

Epiphragmophora califoruiensis var. coutracoste. . . . 54

Eucalodium hippocastaneum Dall, n. sp. . . . . . . . 61

Floriıla shells . . . . . . . . . . . . 31

Fresh water shells in the northeast of Maine . . . . . 9

Ga-trodonta collisella pereallosa Pilsbry, n. var. . . . 134

Gastrudonta (Taxeorlonta) lamellidens Pilsbry, n. sp. . . 134

Halistylus circumstriatus Pilsbry, ı. sp. . . . . . . . 7

Haplopupa Pils. . . . . . . . . . . . . . . . . . 119

Helices, description of three new Eulotæ from Central Asii . . . . . . . . . . 16

Helicina I)ysoni . . . . . . . . . . . . . . . . . 13

Helicina Funcki Ancey . . . . . . . . . . . . . . 87

Helicina Rabei Pilsbry, n. sp. : . . . . . . . . . . 34, 87

Helix devia var. Clappi Hemphill, n. var. . . . . . . . 74

Helix (Lysinœ) queretaroana Dall, n. sp. . . . . . . . 73

Helix (Lysinœ) sebastiana Dall, n. sp. . . . . . . . . 73

Helix, note on a califurnian . . . . . . . . . . . 54

Helix plectotropis var. uniformis Ancey . . . . . . . 17

Hemphillia camelus Pilsbry \& Vanatta, n. sp. . . . . . 44

Holospira (Haplostemma) Cockerelli Dall, n. sp. . . . . 61

Holospira (Haplostemma) Hamiltoni Dall, n. sp. . . . 38

Isaac Lea Chapter of the Agassiz Association, 9, 23, 30,

$42,57,67,80,89,104$

Lanishells from Malay Peninsula, note on . . . . . . 37

Littorina littorea, variations of, . . . . . . . . . . 137

Margaritana marginata var. truncata B. H. Wright, n. var. . . . . . . . . . . . 124

Melania yokohamensis Hartman, n. sp. . . . . . . . . 4 41

Modiola plicatula Lamarck, an extinet locality . . . . 102

Mollusca contemporaneous with the Mastodon . . . . . 121

Mollusks collected in Maldonado Bay, Uruguay by Dr.

Wm. H. Rush . . . . . . . . . . . . . . . 6

Nanina (Macrochlamys?) diadema Dall, n. sp. . . . . $\quad 37$

Nassa Newcombei Merriam, 11: sp. . . . . . . . . . 65

Nautilus pompilius in Southern New South Wales . . . 43 
New species of Tertiary Mollusca fron Vancouver Island

Notes and news.

Notes on Quebec Pupidie and other sliells. . . . . . 110

Notes on slugs . . . . . . . . . . . . . . . . 75

Odontostomia matthewsensis Aldrich, n. sp. (Eocene) . 87

Ommastreplies Bartramii . . . . . . . . . . . . 6

Oryctomya, a new subgenus of Coralliophaga . . . . . 135

Oryctomya claiborneusis Dall, n. sp. (Eocene) . . . . 135

Oxychona unmasked . . . . . . . . . . . . . 87

Paravitrea Pils. . . . . . . . . . . . . . . 130

Partula, notes and corrections . . . . . . . . . . . . 44

Patella geometrica Merriam, n. sp. (M. Miocene) . . . 65

Pecten Davidson Dall, n. sp. . . . . . . . . . . 86

Pecten Palmeri Dall, n. sp. . . . . . . . . . . . 85

Pecten Randolphi Dall, n. sp. . . . . . . . . . . . $86^{2}$

Pinnidie of the United States and West Indies, Synopsis of . . . . . . . . . . . . . . . . . . 25

Pisidium abyssorum (Stimpson) Sterki, n. sp. . . . . . 124

Pisidium pauperculum var. Nylanderi Sterki, n. var. . . 125

Pisidium Singleyi Sterki, n. sp. . . . . . . . . . . . 112

Pisidium splendidulum Sterki, и. sp. . . . . . . . . . 113, 124

Pleas, Elwood (Obituary) . . . . . . . . . . . . 114

Polygyra Ferrissi Pilshry, n. sp. . . . . . . . . . . 92

Polygyra Mearnsii Dall in New Mexico . . . . . . . 69

Polygyra Nelsoni Dall, 1. sp. . . . . . . . . . . . . 74

Polygyra rhyssa Dall, n. sp. . . . . . . . . . . . . 2

Prophysaon Andersoni .. . . . . . . . . . . . 79

Proplıysaon fasciatum . . . . . . . . . . . . . . 79

Prophysaon foliolatum . . . . . . . . . . . . . . . 78

Prophysaon Hemphilli . . . . . . . . . . . . . 78

Prophysaon humile . . . . . . . . . . . . . 79

Proposed census of Michigan Mollusca . . . . . . . . 98

Pseudiberus anisopleurus Ancey, n. sp. . . . . . . . . 17

Pseudiberus uniformis Aucey, 1. sp. . . . . . . . . . 17

Publications received . . . . . . . 34, 44, 69, 115, 126

Punctum californicum Pilsbry, n. sp. . . . . . . . . 134

Punctum Clappi Pilsbry, n. sp. . . . . . . . . . . 133

Pupa ingersolli Anc. . . . . . . . . . . . . . 136

Pupa montanella Ckll. . . . . . . . . . . . . 136 
Pupa sublubrica Anc. . . . . . . . . . . . . 136

Purpura lapillus . . . . . . . . . . . . . 5 . 5

Quarter-decks and jingles [Crepidula and Anomia] . . $\quad 38$

Schazicheila Hidalgoana Dall, n. sp. . . . . . . . . . 62

Sigaretus Oldroydii Dall, n. sp. . . . . . . . . . . $\quad 85$

Sterkia Pils. . . . . . . . . . . . . . . 119

Taxeodonta Pils. . . . . . . . . . . . 132

Teletremata Pils. . . . . . . . . . . . 144

Turritella diversilineata Merriam, n. sp. (Miocene) . . 65

Unio Buxtoni B. H. Wright, n. sp. . . . . . . . . . 40

Unio Diazensis S. H. Wright, n. sp. . . . . . . . . . 5

Unio gibbosa var. armathwaitensis B. H. Wright, n. var. 123

Unio (Lampsilis) amphichrnus Frierson, 1. sp . . . . . 109

Unio Pinei B. H. Wright, n. sp. .... . . . . . . . . 40

Unio reclusus B. H. Wright, 1. sp. . . . . . . . . . 111

Unio Suttoni B. H. Wright, n. sp. . . . . . . . . . . 58

Unio Swordianus S. H. Wright, 1. sp. . . . . . . . . 4

Unio triumphans B. H. Wriglıt, n. sp. . . . . . . . . 101

Unio Walkeri B. H. Wright, n. sp. . . . . . . . . . 91

Unios, notes on the classification of . . . . . . . . 18

Uvanilla regina, a new locality . . . . . . . . . 1

Vallonia parvula and Pupa Holzingeri at Put-in-Bay, Lake Erie . . . . . . . . . . . . . . . . . 82

Vitrea Raderi Dall, n. sp. . . . . . . . . . . 100 


\section{INDEX TO CONTRIBUTORS.}

Aldrich, T. H. 27,97

Ancey, C. F. $16,26,62,66,87$

Baker, Frank C.

Baldwin, D. D. .

Beck, Mrs. M. L. . . . . . . . . . . . . . . . . . 89

Clapp, Geo. H.

Cockerell, T. D. A.

$15,69,75,136$

Cox, Dr. J. C.

Dall, Wm. H.

$2,25,37,61,73,85,100,135$

Ferriss, Jas. H.

Frierson, Lorraine, S.

Hanham, A. IV.

Hartman, Wr. D.

Hemphill, Henry

Johnson, C. WV.

King, Mrs. E. H.

Lawrence, Mrs. E. A.

Letson, Jennie E. .

Lowe, H.

Merriam, John C.

Nylander, Olof O.

Pilsbry, Henry A.

$6,34,45,54,87,92,133$

Simpson, Charles $\mathrm{T}$.

13,18

Stearns, R. E. C.

$1,14,38,102$

Sterki, Dr. V.

112,124

Vanatta, E. G.

Walker, Bryant

Wentworth, Mrs. D. J.

White. J. J.

Williamson, Mrs. M. Burton

Wood, Williard M.

Wright, Berlin $\mathrm{H}$.

$40,55,91,101,111,123$

W right, S. Hart 



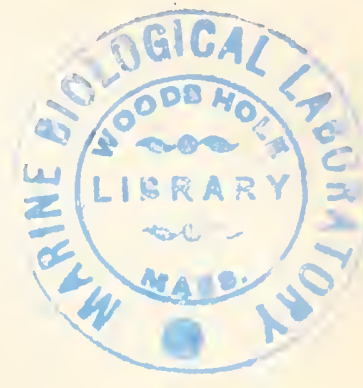

\section{The Nautilus.}

VOI. XI.

MAY, 1897.

No. 1.

UVANILLA REGINA, A NEW LOCALITY.

BY ROBT. E. C. STEARNS.

A few days since, Mr. Charles H. Lawrence, who resides on Boyle Heights in this city, submitted to me for identification a specimen of this fine species which be collected about Christmas, 1895, on San Clemente Island, latitude $32^{\circ} 55^{\prime}$ N., longitude $118^{\circ} 30^{\prime} \mathrm{W}$. This find of Mr. Lawrence's carries the species so far to the north as to include it in the faunal list of California proper. The preliminary description of $U$. regina was published in the ThE NaUtilus for December, 1892, and was subsequently described more fully in the Proc. U. S. Nat. Museum, Vol. XVI, 1893, pp. 350-51, from a specimen collected by Capt. J. D. Porter, of San Diego, Cal., on Guadaloupe Island off the coast of Lower California in latitude $29^{\circ}$ N., longitude $118^{\circ} \mathrm{W}$.

As this easily recognizable species is exceedingly rare at this date, it may be well to note that examples are contained in the collections of the National Museum (No. 125314), of Henry Hemphill and Miss Cooke, San Diego, and of Mr. Lawrence, above-named. The Hemphill and Cooke specimens are part of the lot collected by Capt. Porter.

In my paper on "The Shells of the Tres Marias and Other Localities along the Shores of Lower California and the Gulf of California," this form is listed, as the island of Guadaloupe belongs to Mexico.

In Dr. J. G. Cooper's "Catalogue of Marine Shells collected chiefly on the eastern shore of Lower California," etc., published in 
the Proc. Cal. Acad. Sciences (Series 2, Vol. V, p. 36), he makes the following remarks concerning my "Tres Marias, etc.," list: "Out of 294 in the catalogue, about 200 occur in the Gulf and several others on the west coast. It is not, therefore, as complete a list of Gulf shells as we might expect from collections made by the U.S. Fish Commission Steamer 'Albatross,' with its facilities for dredging and collecting otlierwise." As my paper does not purport to be a list of the "Albatross" collections in the regions under consideration, but only includes incidentally such species as were collected by the "Albatross" naturalists at a few points only, viz., "Baelenas and Pichelinque Bays, etc., so far as the same have been worked up at this date," as is distinctly stated, further comment is unnecessary.

Los Angeles, Cal., A pril 5, 1897.

\section{ON A NEW FORM OF POLYGYRA FROM NEW MEXICO.}

BY W. H. DALL.

Polygyra rhyssa Dall, n. sp.

Shell of six rounded whorls, dark yellowish-brown, the suture rather deep and the spire low but not flattened; nuclear whorls nearly snooth, the rest of the sliell ratler coarsely obliquely striated, the last fourth of the last whorl with rather sharp elevated riblets with wider interspaces and a marked constriction behind the reflected peristome; umbilicus small, deep; peripliery above the middle of the whorl rounded, the entire surface more or less distinctly finely spirally striate; aperture subcircular, oblique, with a reflected and rather solid peristome with a small obscure thickening on its basal part, a light wash of callus over the body, and slightly within the aperture a small oblique elongated parietal denticle. Major diameter 17, minor diameter 14; height $9 \mathrm{~mm}$.

White Mountains of New Mexico, Ashmun.

This species is about the size of $P$. chiricahnana Dall, from which it differs by its strong sculpture, sonewhat larger umbilicus, more distinct suture and oral armature. The form of the moutl resembles that of $P$. pseudodonta Dall, but the basal thickening of the lip is not notched and the slell is decidedly larger, more coarsely sculptured and somewhat darker in color. It forms another illustration of the effect of insulation on the mountain peaks by arid lowlands 
in producing differentiation in a single type of shell. P. levettei, chiricahuana, ashmuni, pseudodonta and rhyssa are obviously offshoots of a common stock.

\section{CONCHOLOGICAL NOTES FROM LOUISIANA.}

BY LORRAINE S. FRIERSON.

Being, so far as I know, the only student of conchology in Louisiana, perhaps a few notes may be of interest.

My station consists of an arm of Red River (Bayou Pierre), a lake and numerous creeks.

In these waters occur about 50 species of Mollusca, of which 30 are Unionidæ. An interesting fact, and one which $I$ have never seen mentioned, is the sharp line of separation between the forms found in the creeks and those growing in the Red River waters.

In the creeks are found 5 Unios and 2 Anodontas. While in the Red River waters are found 25 Unionidæ. No creek shell grows in Red River waters (with but two exceptions noted below) and no species living in Red River waters are ever found in the creeks.

At the junction of a creek with the river occurs a zone where no mollusca can be found. The exceptions noted are $U$.texasensis Lea, which, while pre-eminently a creek shell, is found sparingly in Red River waters. Another possible exception is in the case of $U$. declivis Say. This shell is found abundantly in the creeks, and grows to a large size. A rather rare shell is found in the Red River waters which is said by our authorities to be a form of $U$. declivis Say known as tetralasmus Say or geometricus Lea.

Declivis proper never occurs in the Red River waters, nor does tetralasmus ever grow in creek waters. Perhaps this fact will help show that these shells are really distinct species and not synonyms.

The most variable and, perhaps, the most abundant Unio is $U$. multiplicatus Lea. West of the Mississippi drainage this shell merges into $U$. eightsii Lea, and here, at the middle ground, a mixture of types is seen. An interesting shell is sparingly found here, close to its extreme southern limit, probably. It is a dwarfed, almost "ruu out" form of $U$. donaciformis Lea. Another "Yankee down south" is a very small but brilliantly colored Anodonta suborbiculata. Say. It is found in the soft, deep mud of Edwards' Lake, and disputes its territory with Anodonta virens Lea. A. imbecilis 
also grows with these, but does not live in the mud, but escapes this by growing in the fissures of the cypress trees, a prisower for life, by choice.

Thus far my researches have been productive of one new species, $U$. friersoni Wright, and the extending of habitat of three shells. But I hope to accomplish much more in the future, which, if successful, will be given to the readers of The Nautilus.

Frierson Mill, De Soto Parrish, Louisiana.

\section{CONTRIBUTION TO A KNOWLEDGE OF UNITED STATES UNIONID无.}

BY S. HART WRIGHT.

\section{(Concluded.)}

Unio Swordianus sp. nov.

Shell oval, massive, very inequilateral, rounded before, highly arched above and rounded at base, very bluntly pointed behind. Sides flattish, constricted slightly or not at all, and the umbonal ridge usually obsolete. Epidermis brownish or somewhat horncolored, rayless, and the surface roughened with close growth-lines. Ligament darkened, heavy, short and much elevated. Beaks pointed, small and very low. Beak cavity shallow, extending slightly under both cardinal and lateral teeth, thus making it very broad and with obtusely rounded sides. Cardinal teeth double in the left valve, single in the right and smoothish, or crested and short. Lateral teeth heary, slightly curved, wide apart, arising from a thick dorsal plate. The cardinal of right valve with an oblong groove at its base. Cicatrices distinct; dorsal cicatrices confluent into an oblong groove under the dorsum. Pallial impression deep and denticulate. Nacre usually pure white, often more or less with waxy discolorations or mottlings or even dirty white. Width 4 inches, length 2 , diameter $1 \frac{5}{8}$.

Habitat: Powell's Creek, Lee Co., Va.

Remarks: Affinity, U. bursapastoris B. H. Wright and U. abacus Hald. Our shell differs from the first in luaving a lighter epidermis, an arched dorsum, shell cavity greater, beak cavity very much less, being nearly extinct, and the posterior dorsal area narrower and very abrupt in its descent. From $U$. abacus it differs in the beak cavity, and is much more inequilateral. Ten specimens were obtained from the collector, Mr. T. F. Sword, for whom it is named. 
Unio Diazensis sp. nov.

Shell small, oval, thin, bluntly or truncately pointed behind, and biangulated there; rounded obliquely in front, the curve meeting the dorsal line with a distinct angle. Epidermis reddish-brown, lighter above on the first growth, finely and obscurely striate with minute scales, more apparent near the base. Lines of growth distant, about two. Rays nearly obsolete, or, if present, seen faintly on the anterior end, or on the first growtl. Umbonal ridge well-defined, rather narrow. Posterior slope rather broad and raised into a keel. Dorsal line nearly straight. Umbos small, broad and not raised. Beaks with a double series of granular undulations. Dorsal plate thin. Shell cavity rather deep and broad. Beak cavities slight. Cardinal teeth very small and light, more or less compressed. Lateral teeth very narrow, slim and nearly straight. Anterior cicatrices distinct; posterior confluent. Cardinal of right valve single. Dorsal scars under the plate. Nacre salmon or coppery. Width $1 \frac{1}{2}$ inches, length $\frac{7}{8}$, diameter $\frac{1}{2}$.

Habitat: Lake Diaz, Volusia Co., Florida.

Remarks: In 1887 we gathered about 2,000 of these little thin shells in Lake Diaz, no otlier Unio being found in that lake, except $U$. amygdalum Lea. They were always in white sand, with clear and rather shallow water, and nearly all of one size. Affinity, $U$. fuscatus Lea, from which our shell differs in being smaller, less transverse, more inflated, having a much higher umbonal ridge well marked, while in $U$. fuscatus the ridge is nearly or quite obsolete. From $U$. coruscus Gould the Diaz shell differs in having always thin lateral teeth, a thin dorsum and smaller cardinals and a high keel, and is always a thinner shell. It differs from $U$. fryanus B. H. Wright in being much less polished, lighter, less solid, fewer rayed, greater umbonal ridge and more attenuated in front. In a "Check List of N. A. Unionidae," published in 1888, a species of Unio was listed as "U. diasensis," but was never published, and therefore does not preoccupy the similar name now given above.

Note.-Types of all the above species will be sent to the National Museum and duplicates of the types to the Academy of Natural Sciences of Philadelphia.

Errata.-In The Nautilus, X, No. 12, page 136, first line, for " triangular, clavate," read "triangular-clavate." Eighth line, for "narrower," read "narrow." Page 137, ninth line above the bottom, for "groove in the," read " groove under the." 
THE NAUTILUS.

LIST OF MOLLUSKS COLLECTED IN MALDONADO BAY, URUGUAY, BY DR. WM. H. RUSH, U. S. N.

BY HENRY A. PILSBRY.

In the Naurilus for September, 1896, a list may be found of the non-marine mollusca collected in Uruguay and Argentine Republic by Dr. Rush. Descriptions of the new species mentioned in that paper have been published in subsequent numbers, and in the Proceedings of the Academy of Natural Sciences of Philadelphia for 1896, pp. 360-365, and plates 26, 27, and Manual of Conchology, 2 d ser., Vol. XI.

The marine shells obtained by him while with the South Atlantic Squadron were nearly all taken in Maldonado Bay, dredged in from three to six fathoms of water, the limpets, etc., from the shore excepted. The few forms collected elsewhere than at Maldonado and vicinity have the localities indicated below. In this connection it may be mentioned that the squids which jumped aboard the Yantic, as described by Dr. Rush in Nautilus, VI, p. 82, turn out to be Ommastrephes Bartramii. Among the forms enumerated below and in the several published lists of shells from this general region, it is somewhat remarkable that some groups usually rather numerous, such as Rissoido, are not represented. The occurrence of a number of northern species is also noteworthy. There are also in the series collected about a dozen forms found only in poor condition and not yet identified. The descriptions of new species will shortly appear, with figures, in Proc. Acad. Nat. Sci. Phila.

\section{Gastropod.}

Acmeca onychina Gould. Gorritti Island, Maldonado Bay. This bay was the type locality of Patella mülleri Dkr., a synonym of Gould's species.

Bittium sp.

Bullia cochlidium Kien.

Bullia globulosa Kien. Maldonado Bay. Very heavily calloused fossil specimens occurred in the wall of fort at the Mus. La Plata, Argentine Republic.

Bullia Uruguayensis n. sp. Shell somewhat like B. globulosa Kn., but more slender, the spire much longer. Surface smooth except for two to four spiral impressed lines separated by convex low cords, just below the impressed suture, and fine spiral striæ on the 
base; growth-lines fine and slight. Light flesh colored. Whorls about $6 \frac{1}{2}$, the first globose, the second and third with rather coarse longitudinal folds, which persist longer at the upper part of the whorl ; remaining whorls convex, foldless; the last whorl oval, regularly con . vex, contracted below, with a wide arcuately striate siphonal fasciole bounded above by a strong narrow spiral rib. Aperture a little over half the alt. of shell. Columella broadly concave above, having a strongly twisted fold below, which projects at the junction of the short basal canal with the cavity of the aperture, sloping strongly to the left below the projecting fold; anterior notch wide. Parietal callus rather thin, spreading far forward.

Length $22 \cdot 5$, diam. $12 \mathrm{~mm}$.

Maldonado Bay. This species is certainly not the young of $B$. cochlidium, although in nry opinion d'Orbigny's fig. 25 of plate 61 of the Voy. Am. Mérid. was drawn from a specimen of the form here described. The characters of columella and sculpture also incline me to consider the present species distinct from $B$. Lamarckii Kiener (Iconogr., pl. 3, figs. 6, 6).

Chlorostoma (Omphalius) corrugatum Koch. Irochus patagonicus Orb. is a synonym.

Columbella avara Say.

Columbella obesa var. decipiens C. B. Ad.

Columbella sertulariarum d'Orb.

Crepidula aculeata Gmel.

Cylichnella bidentata Orb.

Fissuridea patagmica d'Orb.

Halistylus columna Dall.

Halistylus circumstriatus n. sp. Similar to H. columna in size and contour, but the whorls are encircled by numerous impressed brown lines. H. pupoideus (Cpr.) Dall, of California, (Proc. U. S. Nat. Mus., xv, 1892, pl. 19, f. 2) is a third species of this interesting group. It is spirally sculptured like circumstriatus, but has very convex whorls, and there are other differences.

Natica Isabelleana d'Orb.

Natica maroceana Dillw. (?). Worn young shells.

Ocinebra cala n. sp.

Olivancillaria auricularia Lam. Maldonado Bay; also fossil specimens in the Fort wall at La Plata Museum.

Olivella Puelchana d'Orb.

Scala elegans d'Orb. (probably). 
Scala tenuistriata d'Orb.

Siphonaria Lessoni Blainv. Gorritti Island, Maldonado Bay. Triforis sp.

Turbonilla iutermpta Totten.

Turbonilla sp. Specimens worn.

Turbonilla dispar $\mathrm{n}$. sp.

Turbonilla uruguayensis $\mathrm{n}$. sp.

Urosalpinx Rushii n. sp.

\section{POLYPLACOPHORA.}

Chcetopleura Isabellei d'Orb. Maldonado Bay, with the following.

Chcetopleura Teluelcha d'Orb. Maldonado Bay. Carpenter's Ch. armillata (Man. Conch., xiv, p. 39) described from Gorritti Island, is a synonym.

\section{Pelecy poda.}

Azara labiata Maton. Pond near Maldonado.

Azara labiata var. nimbosa Sowb. Pond near Maldonado ; brackish or nearly fresh water.

Corbula cariboen d'Orb.

Corbula Iheringiana n. sp.

Corbula Lyoni n. sp.

Corbula patagonica d'Orb.

Crassatella (Eriphyla) lunulata Con.

Crassatella (Eriphyla) maldonadoensis n. sp.

Cytherea rostrata Koch.

Diplodonta semiaspera Phil. (Lucina semireticulata Orb.).

Donax hanleyanus Phil.

Lyorsia hyalina Conrad.

Lyonsia sp. A nearly equilateral species, new to me.

Lucina squamosa Lam.

Mactra isabelleana d'Orb.

Mulinia near lateralis Say.

${ }^{1}$ Carlos Maria de Pena has called attention to the fact that padre Dámaso A. Larrañaga, a naturalist of Montevideo, in his "Memoria Geologica sobre la formacion del Rio de La Plata, deducida de sus conchas fosiles," written in 1819 (? published in 1821), created the genus Matonia for Mya labiata of Maton, thus antedating d'Orbigny's name Azara. I have not seen the work, and would decline to make a change until the proper publication and date of Matonia is made positive. See Anales del Mus. Nac. de Monterideo, I, 1894, p. 1. 
There were also worn valves of several other Lactride collected. Mesodesma arechavalettoi (Ihering MS.) Pilsbry. Maldonado Bay, Uruguay (young); Mar del Plata, Argentina.

Mytilus darwinianes Orb.

Mytilus edulis L. (? platensis Orb.).

Mytilus canaliculus Hanl.

Nucula puelcha d'Orb. N. uruguayensis E. A. Smith does not seem to differ materially from this species.

Ostrcea puelchana d'Orb.

Pecten nucleus Born, var.?

Pecten sp. undet.

Pectunculus longior Sowb.

Petricola like pholadiformis, but less strongly sculptered. One valve.

Plicatula ramosa Lam.

Semele (Abra?) uruguayensis 11. sp.

Tagelus gibbus Speugl. (platensis Orb.).

Tellina uruguayensis E. A. Smith.

Thracia Rushii n. sp.

\section{ISAAC LEA DEPARTMENT.}

[Conducted in the interest of the Isaac Lea Conchological Chapter of the Agassiz Association by its General Secretary, Mrs. M. Burton Williamson.]

The name of Miss Zeola Downing, Long Beach, California, is added to the membership roll of our Chapter.

When last heard from Miss Anna Goodsell of San Diego, California, was in Cairo, Egypt, after having visited many countries in the Orient.

FRESH WATER SHELLS IN TIIE NORTHEAST OF MAINE.

[From the report of Mr. Olof O. Nylander. From the Transactions of the Isaac Lea Conchological Chapter for 1896$]$.

This article is devoted to the fresh water shells found in the Fish River Lakes and Aroostook River, northeast of Maine. After securing a good supply of provisions, tent, boat and apparatus needed for a long collecting trip in the forest region, a man was employed to accompany us through the journey, and a man with a team to haul me the distance of 25 miles to Cross Lake on the Fish River. 
Arriving at Cross Lake my work was immediately to collect and my companion's duty throughout the journey to prepare the tent, cut wood and cook, and other duties connected with camp life in the woods.

At the Cross Lake inlet the following were collected: Unio complanatus, Margaritana undulata, Anodonta fragilis, Splucrium sulcatum, Pisidium compressum, $P$. variabile, $P$. n. sp., Planorbis campanulatus $P$. bicarinatus, $P$. deflectus, Limuca emarginata, L. desidiosa, Ponatiopsis cincinnatiensis, etc.

The second place visited was on the west side about 2 miles south from the inlet. Planorbis trivolvis was obtained in a place that appeared to be covered with water only in the Spring. Ancylus parallehus was found in large numbers, and a lot of good large specimens of Limnca emarginata in two feet of water. They seemed to feed on vegetation on the rocks. A little further down on the west side was a small stream in which a lot of Sphoria and Pisidia were obtained. Unio complanatus Sol., Margaritana undulata Say and Anodonta fragilis Lam., are found all over the Fish River Lake, and need not be referred to as of especial interest to any locality.

On the east side where some large hills rise from the lake a small lot was obtained by dredging; nearest the shore Pomatiopsis cincinnatiensis were plentiful in 15 feet of water; Campeloma decisum, of small size, Pisidium variabile and $P$. compressum were found from the shore to 25 feet, showing some variation in forms. On the shore Succinea ovalis, and, near by, in the woods under rocks, $S$. avara were found. Also Conulus fulvus, Strobila labyrinthica, Zonites exiguus, Carychium exiguum and fragments of Pupa or Vertigo.

The south end of Cross Lake afforded the best dredging ground, and some time was spent here. Pomatiopsis cincinnatiensis Lea, was very plentiful, and Valvata tricarinata Say, V. sincera Say, were collected from 5 to 20 feet. Planorbis trivolvis, $P$. companulatus, $P$. bicarinatus, $P$. deflectus and $P$. hirsutus were not plentiful.

One of the most interesting collecting grounds is Square Lake, which is the largest and handsomest lake in Aroostook Co. At the inlet from Cross Lake the bottom is covered with large and fine specimens of Limnoe emarginata and the var. Mighelsi. Planorbis parvus (?) Say, Planorbis sp.?, a peculiar specimen, $P$. campanulatus, a form of small size, $P$. bicarinatus, Physa ancillaria Say, are plentiful in this place, but nowhere else in this region to iny knowledge. The shore is covered with dead shells of the above named species. 
From the inlet at the northeast of Square Lake, the east side was followed to the south, a distance of about 8 miles. The wind blowing prevented us from doing any dredging, and the bottom is generally stone.

In the south end of the lake the bottom is covered with fine sand and afforded very fine dredging ground for 2 or 3 square miles. From the shore to 10 feet deep Pomatiopsis cincinnatiensis was very common, and a few specimens of Pisidium were found from 10 to 25 feet. Valvata tricarinata and $V$. sincera were found, but beyond the depth of 25 feet all the shells seemed to disappear, and the dredge was filled with nothing to collect. The western shore of the lake is rocky and the only place visited is Limekiln Point, where I have spent a good deal of time in past years. This very interesting locality of the Upper Silurian limestone of the Lower Helderberg group, contains many fine specimens of fossils, many of them peculiar to this locality. A very fine collection has been found at this place. *** From Limekihn Point to Eagle Lake every part was carefully surveyed, yet nothing of special interest appeared. Eagle Lake is the longest of Aroostook Lakes, being about 18 miles long and 1 wide. In one place I could not reach bottom with a 100 foot line.

Along the north shore I obtained the same species as I found in Cross and Square Lakes, and from the deep water I obtained only rocks and gravel, and not a fragment of a shell. Where the south branch of Fish River enters Eagle Lake, in a sand bar, a lot of fine living specimens of Sphrerium striatinum Lamk., and Margaritana undulata were collected. Throughout the thoroughfare to Portage Lake Sphcerium striatinum is plentiful. * * * * Nothing new was added. A good deal of hard work was done dragging the boat through the rapids and over rocks and ledges to Portage Lake.

Portage Lake is in parts surrounded by high hills and a very attractive place for tourists. 'The western part is a good finding place for mollusks. Pomatiopsis cincinnatiensis Lea, is obtained somewhat larger in size as it approaches deep water; Planorbis companulatus and $P$. bicarinatus are also of large size, and the angles of the whorls in bicarinatus are very sharp. Planorbis deflectus is found at the bend of the lake, very large, from 8 to $9 \mathrm{~mm}$.; Valvata tricarinata and $V$. sincera are also of good size.

Near the south and east corner of the lake a colony of good, large specimens of Campeloma decisum in 6 inches of water were found. This 
was the first place I had any opportunity to see them in any number in the north of Maine. From this place I had intended to go to Big Fish Lake, about 20 miles west from Portage Lake, but some of my provisions were spoiled by hot and rainy weather and I was not able to obtain any from the farmers, therefore at the south of the lake I engaged a team to transport us to Aroostook River, a distance of 10 miles, over a good road.

A roostook River is rapid and rocky the whole distance from Ashland to Caribou, and shells are seldom found. Margaritana margaritifera Lin., are found among the rocks in from 5 to 6 feet of water; a dozen living specimens were obtained in the distance of 40 miles. Anodonta fragilis lives in the small streams which empty into the river. Planorbis bicarinatus and Physa heterostropha are sometimes plentiful. Sphcrinm truncatum and a few Pisidia have been found. Campeloma decisum were collected in two places, and Ancylus tardus Say, was found on rocks in a place near Caribou in the summer of 1895 .

After three weeks have been spent in the woods it is pleasant to arrive at home again. The specimens collected during this trip have not all been identified.

In past years I have received valuable assistance from Professor H. A. Pilsbry. Mr. Bryant Walker, of Mich., sent me a dredge which has been of great value, and Dr. V. Sterki has kindly determined Pupidce, Tertigos and Pisidia. My thanks are due to these gentlemen.

TO SUBSCRIBERS.

We wish to impress upon our readers that subscriptions to THE Nautilus are payable in advance, and that we do not discontinue until notified. Were it not that some subscribers forget to pay at the end of the year it would not be necessary to thus emphasize the terms of subscription. What is a small matter to each individual reader, becomes in the aggregate a large one to us. Our deficit in publishing Vol. $\mathrm{X}$ has been somewhat less than in the previous year, but is still more than we can afford to lose. Our screed upon this topic in Jamuary seems to have been misunderstood by some cautious persons we have heard from, who for fear The Navtilus would be discontinued, kept their dollars! With this kind of support we could not have continued another month ; but stalwart friends of the cause in Massachusetts, Michigan and California said "The NAUtilus shall not stop; we will stand by if needed." With this assurance we enter upon another volume.

All who are in arrears are requested to "pay up" this month. 


\section{The Nautilus.}

VoI.. XI.

JUNE, 1897.

No. 2.

HELICINA DYSONI.

BY CHARLES T. SIMPSON.

While collecting shells in the Island of Utilla, on the north coast of Honduras, I frequently visited a Brickly Thatch palm grove which lay on the south shore. The Brickly Thatch is a curious, small palm, with straight, slender stems, a little larger than one's wrist, and about twenty feet in lieight, surmounted by a crown of shining, fan-shaped leaves. The bases of these trees are slightly enlarged, and they stand on a cone of stilted roots, which, with the soil and rubbish among them, fill the conical space almost solid. They grow thickly to the exclusion of all other vegetation, and the curious bunches of roots completely fill the space on the ground and make it quite difficult and awkward to get around. Under the alnost twilight of this dense copse I found excellent collecting, and I there discovered Colobostylus andrewse, Cylindrella bourguignatiana and several other new species. Among other shells I kept finding specimens of the pretty little Helicina dysoni, but always dead and generally faded. An enterprising collector is never satisfied with dead shells, and I searched everywhere to find this mollusk aliveunder the dead, fallen palm leaves, in what rubbish lay around, on the stems of the palms, and among their tough, matted roots-but in vain, and I finally concluded that the colony, of which these were remnants, had either died out or migrated.

One day I visited a part of the grove that I had not seen before, a spot at its edge, and here I found a single living tree which had

1 Thrinax radiata. 
fallen over. I was interested in the crown of it from a botanical standpoint, and on examining the flowers and leaves I found a half a dozen or more of the snails I so much wanted on the under side of the latter. Then I looked up over head and saw, to my astonishment, that there were thousands of them. I had been walking day by day under a firmament of palms that was literally star-spangled with the pretty Helicina dysoni. It was like the story of the navigators who were perishing with thirst while sailing in the fresh water off the mouth of the Amazon.

But finding the Helicinas was one thing and getting them was quite another. I tried to shake the trees, but so thickly did they stand that their tops touched each other everywhere, and I might as well have tried to shake the post of a piazza. Then I started to climb one of them, but the hard, sharp fibres of the wood filled my hands and tore my clothes, and I gave that up. I looked for a pole but there was none to be had. The mangrove scrub between me and the sea was all short and crooked, and I found nothing snitable in the heavy tropical forest north of me, so I went home to the ship that night with the dozen or so I had captured, and a few dead shells. The next day I came by way of some clumps of a curious little palm, with slender stens an inch or more in diameter, growing in low ground and crowned with feathery leaves. I found a straight one among these, some 15 or 16 feet long, cut it and trimmed it with my pocket-knife, and when I reached the palm grove I soon had a shower of Helicinas falling around me. One soon tires of collecting anything that is very abundant, and in a little while I had all I cared for.

The moral of this little sketch, if it has any, is that in collecting it is necessary to look everywhere, even in the most unlikely places, and my experience has been that the collector who never allows anything to escape his eyes is, as a rule, the most successful.

DESCRIPTION OF A NEW SPECIES OF ACTAEON FROM THE QUATER-
NARY BLUFFS OF SPANISH BIGHT, SAN DIEGO, CALIFORNIA.

BY ROBERT E. C. STEARNS.

\section{Actaeon Traskii.}

Shell small, conical above, rounded below, rather solid, glossy; sculptured by numerous fine impressed lines or grooves which be- 
come wider toward the base of the body whorl, making the sculpture of this part of the shell lirate; the lire sometimes slightly grooved; otherwise sculptured by sharp, close set incremental threads, these are subordinate to the spiral sculpture. Color dull cream-white with two obscure rufous bands on the body whorl. Spire short, obtusely conical; whorls six ; sutures distinct, narrowly channelled ; aperture about two-thirds the length of the shell, sharply angulated above, rounded and effuse below, finely lirate and glossy within, with a thin glazing on the body whorl. Outer lip simple. Columella short, with a fold curving around to and thickening the edge of the lip below, which is moderately produced.

Length of shell 11 millimetres.

Length of body whorl 9 millimetres.

Breadth 6 millimetres.

The foregoing description is based on a single example in the collection of Mr. Homer Hamlin, of Los Angeles, Cal. The above form was collected by me in the same locality in the fall of 1887 the specimens are now in the U. S. National Museum.

It is a more robust and solid shell than the related species punctocclatus Cpr., which occurs in the same locality, and which is found living in many localities along the shore from Monterey, southerly. I have named the above for the late Dr. John B. Trask, one of the founders of the California Academy of Science, and a pioneer in natural history investigations on the West Coast.

Los Angeles, Cal., March 15, 1897.

\section{NOTES ON AGRIOLIMAX.}

BY T. D. A. COCKERELL.

The accompanying figures were drawn by the writer several years ago, and sent to Mr. W. G. Binney, who kindly had them engraved along with others which were published in the Supplements to Terr. Moll., vol. V. These three, however, were not published, and it is thought well to present them at this time.

Fig. 1 represents the liead and anterior part of the mantle of a specimen of Agriolimax agrestis (L.) collected by Mr. Pilsbry in Philadelphia in 1889. The mantle is FIG. 1. bilobed in front, and the specimen represents the monstrosity bilobatus Férussac. 
Fig 2 represents the jaw of a specimen of Agriolimax campestris var. hyperboreus (Westerlund), collected by Prof. H. F. Wickham at Soda Spring, Yakima Co., FiG. 2. Wash., in 1889.

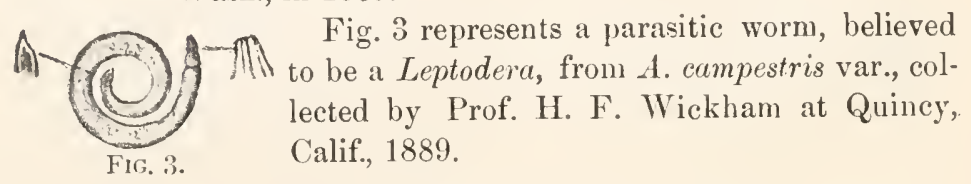

\section{DESCRIPTIONS OF THREE NEW EULOTE (HELICES) FROM CENTRAL ASIA.}

\section{BY C. F. ANCEY.}

\section{Cathaica Funki n. sp.}

Shell much depressed, openly and rather widely umbilicated, of a somewhat solid substance, opaque, bluish-white, paler beneath and also above the periphery, more or less spotted with a few punctiform and pellucid dots beneath, a little shining, but not much so above. Spire greatly flattened, generally scarcely raised, barely convex, apex obtuse, corneous or dark colored. Whorls 5, convex, regularly increasing, furnished with oblique smooth lines of growth, somewhat irregular; the last whorl barely and gently deflected in front, subdepressed above, more or less roundly angled above the middle, the angle being very obtuse and obsolete towards the aperture; more convex around the umbilicus. Aperture oblique, well rounded, scarcely lunate, ample, margins not remote. Peristome simple, widened, briefly expanded, chiefly at the columellar edge, moderately thickened at the base and columella, not reflected.

Greater diam. 16-17; lesser $13 \frac{1}{2}-14$; height $7 \frac{3}{4}-8$; of aperture $6 \frac{3}{4}-$ $7 \frac{1}{2}$ mill.

Karghalik, Central Asia (teste E. Funk).

Some years ago, I received this new species under the unpublished name of Helix Funki "Böttg.", and do not think it was ever described since. In form it is like Helix obvia Hartm., but the shell is of the same type and has the same characters of aperture as Helix stoliczkana Nevill, of Yarkand; it, however, lacks the two straight brown bands of that species, in which they are a constant feature, and is more shining and less rugose. The style of color is quite similar to that of Helix rubens, although paler, at least as regards the three specimens now before me. 
From the same source and locality (Karghalik), I also obtained the form I have described as Bul. kuschukewitzi, var. Funki.

II. Pseudiberus uniformis n. sp. $=$ Helix plemtetropsis (in parte) von Mart. et al $=H$. plectutropsis var. uniformix, Ane. olim.

This is the so-called variety that I had formerly looked upon (Le Naturaliste, 1887, p. 167) as a variety of Martens' Helix plectotropis. At that time I had a single specimen of the latter, but I now have more of the typical form (from Lake Tssyk-Kul and Karghalik) for comparison, so that I consider uniformis a very distinct, although allied form. Altogether it comes from a different district (Arassan Culak) and appears to be very constant. The characteristic features having already been described by myself in the paper I alluded to, I shall simply say that uniformis is a paler and more depressed shell than plectotropis, with a wider umbilicus and much more acute keel.

\section{Pseudiberus anisopleurus n. $;$.}

Shell rather thin, of a greenish-horn color, coarsely sculptured, somewhat shining, closely related in form, size and shell claracters to Nevill's mataianensis, found in the Dras Valley, region of Ladak, but of different and uniform color. Spire convex, not much elevated, obtuse. Whorls 5, convex, furnished with broad, distant and irregular ribs, closer and more regular on the under side, but never obsolete. Suture furnished with an appressed keel, canaliculate above. Body whorl briefly, but not abruptly falling in front, convex above the inserted keel, more so below, the keel somewhat irregular, margined on both sides, especially above where the impressed line is very conspicuous. Unbilicus medium-sized. Aperture oblique, transversely oval, livid within, scarcely angular internally, barely lunate. Peristome white, moderately thickened, expanded, reflected below, chiefly towards the umbilicus. Margins not remote, connected by a thin shining callosity.

Great. diam. $14 \frac{1}{2}$, less. $12 \frac{1}{2}$; height 8 , of aperture $6 \frac{1}{2}$ mill.

Locality unknown, but judging from its very well marked affinities, this fine liew species for which I am indebted to my friend Dr. A. Vayssiere, is undoubtedly from Central Asia. At a glance, I had mistaken it for mataianensis, which is known to me from the description and figure only, but am now satisfied it is very distinct. The color, sculpture and characters of the suture are not the same. In the latter respect the present Pseudiberus is more like the true $I$. plectotropis, but the color is equally different, the size smaller and the ribs larger and much less numerous and regular. 


\section{NOTES ON THE CLASSIFICATION OF THE UNIOS.}

BI CIIAS. T. SIMPSON.

In 1834, Dr. Jared P. Kirtland published the statement that the sexes of the North American Unios were distinct, and that the shell of the female was characterized by a swelling in the post-basal region, which was wanting in that of the male. ${ }^{1}$ He seems to have thought at that time that all the American species were thus distinguished, but in a later publication he stated that he believed that about two-thirds of the American species have differentiated shells. ${ }^{2}$

This was corroborated by Dr. Isaac Lea, ${ }^{3}$ who showed that this enlargement of the shell of the female was for the purpose of holding the charged oviducts, which, in such forms, were found in the posterior part of the outer branchiæ. Lea, at various times, described the soft parts of some 250 species of Naiades, mostly North American Unios, and in a considerable number of these he found that the embryos occupied the entire outer branchix, while in four species-Unio multiplicatus Lea, U. rubiginosus Lea, U. subrotundus Lea and $U$. kleinianus Lea-they filled all four leaves of the branchice.

In a statement made before the Boston Society of Natural History ${ }^{4}$ Agassiz proposed to divide up the Naiades into genera founded on the differences of structure of the animal as well as the characters of the shell, and to include under one genus a number of species of Unios, some of which (including $U$. alatus Say, the first one in the list) have the post-basal inflation of the female shell, and others in which it is lacking. Subsequently he used the name Lampsilis, of Rafinesque, with $L$. cardium Raf. as a type, and he gives in his list under this genus a number of species, all of which have the differentiated shells, and carry the young in the posterior part of the outer branchise. ${ }^{5}$

In Trie Nautilus, for December, 1895, Dr. V. Sterki published the results of his observations on American Unios, and gives some

${ }^{1}$ Observations on the Sexual Characters of the Animals belonging to Lamarck's family of Naiades. Am. Jl. Sci. and Arts, XX Y I, 1834, p. 117-120.

${ }^{2}$ Remarks on the Fexes and Habits of some of the Acephalons Bivalve Mollusca. Proc. Am. Assn. Adv. Sci., 1851, p. 85.

${ }^{3}$ Description of New Freshwater and Land thells. Tr. Im. Phil. Foc.

'Proc. Bost. Soc. Nat. Hist., III, 1S4S-51, p. 356.

${ }^{5}$ Ueber die Gattungen unter den Nordamericanischen Najaden. Irch. für Naturg., 1852, pp. 41-52. 
very interesting statements regarding their anatomy. He places those species in which the young are carried in the posterior part of the outer branchire, and the female shell is inflated in the post-basal region, in a group designated as $\mathrm{A}$, which he states, as a rule, have bright shells, and are gravid from late summer to winter. In group $\mathrm{B}$ all four branchia are charged throughout their length; the shells are generally dull colored, and do not show marked differences between male and fenrale.

In my eartier attempts at classifying the Naiades, I based ny arrangement almost wholly on shell characters. I did this because in the splendid collections of the National Museum we liad either the types or authentic specimens of a very large proportion of the known, valid species, and because I was anxious to see whether a classification could be based on the shells alone that would be supported by the evidence of the anatomy. I have since then examined the soft parts of a large number of species, and carefully tabulated the results of the work of Lea and others, and I am exceedingly gratified in being able to say that in almost every case the characters of the animal and shell seem to essentially agree. In a few instances, the evidence of the former has thrown important light on relationships which conld not be determined with certainty from shell characters alone, and vice versa. In some cases, where there at first seemed to be a contradiction, more careful study has shown essential agreement.

There are certainly two great groups of North American Unios. In the first the shell is generally, though not always, covered witl a hard, smooth, bright epidermis, which is often rayed or marked with patterns of attractive color. It is rarely sculptured with anything beyond slight concentric ridges, and in only a few instances has it any ridge on the posterior slope, and, with possibly one or two exceptions, the outline is never arcuate, even in old agre. The female shell is usually decidedly swollen in the posterior basal region to accommodate that part of the outer branchia which contains the embryos. The beak sculpture is generally delicate, consisting, for the most part, of close, fine, paralled ridges, which have a tendency to fall into an anterior and posterior loop, tlie latter sharp pointed below.

The embryos are contained in the posterior part of the outer branchia. The ovisacks are distinct, being separated by a suture, and the whole marsupium is rounded below, projecting generally, 
especially when filled with young, below the inner gill. A slight fold commonly runs around it near the base, and parallel with it, which is often seen even when the whole is distended with young. The specialized marsupiun of this group may be easily detected, even when it is empty, and when full it is a most beautiful object, the bases of the ovisacks being often rounded and colored. There are three or four, perhaps more, groups of this great division; one typified by such oblong, smooth forms as Unio anodontoides, luteolus, cariosus and lavissimus; another in which the inflated part of the shell is of different texture from the rest, is often distinctly marked out, and sculptured with radiating ridges ending in teeth at the edge, including Unio pcrplexus, sulcatus, brevidens and the like; a third containing short forms with a distinct posterior ridge and remarkably painted epidermis, such as Unio securis, donaciformis and, perhaps, caperatus and dromus.

This great group is certainly entitled to generic rank, and the divisions I have indicated may perhaps be made into subgenera. I believe that the name Lampsilis, proposed by Rafinesque, and afterwards used by Agassiz, may be applied to this genus.

The second great group contains forms in which there does not appear to be any special differentiation in shells due to sexual characters, and which are true Unios. In fact I consider the question as to the distinction or separation of the sexes in the true Unios and Auodontas far from being settled, although it is one which has been fought over since the time of Leuwenhock until the present. A number of excellent authorities have declared, after making many careful dissections, that the sexes of these forms were separate; others equally capable have concluded that they were united, others that the earlier stage was that of a male and later on a fenale, while still others claim to have found the sexes united in some individuals and separated in others.

The shells of this great group are usually rather dull in color externally, they often have a decided posterior ridge, and generally become arcuate in outline in old age. The beak sculpture, as a rule, is rather coarse and irregular, in most cases consisting of a few nearly straight bars, which are thickened where they pass over the posterior slope. At the extreme anteriur and posterior dorsal portions of the young shell there are often found fine, radiating ridges, which sometimes pass below in to the heavy, horizontal undulations. The embryos are distributed throughout the whole length of the 
gills, the branchire when distended with them being perfectly smooth outside, and looking like pads. There seem to be two great groups of these forms, one characterized by simple, oval or oblong shells destitute of any strong sculpture, and probably carrying the young, as a rule, only in the outer branchire, and this includes in the United States such forms as Unio gibbosus Bar., U. tetralusmus Say, $U$. buckleyi Lea, $U$. crassidens Lam. and U. complanatus Sol., and these are probably closely related to the European species. The other group has short, rather solid, often inflated shells, with a wide, heavy hinge plate, and it includes nearly all the pustulous, and all the plicate sculptured forms. Lea found the inner and outer gills filled with embryos in four of these species: U. multiplicatus Lea, subrotundus Lea, kleinianus Lea, and rubiginosus Lea, and it is probable that, under favorable conditions, all or most of these species carry young to some extent, in the imner as well as the outer gill, though so far as I have observed the inner gill is never so compactly filled as the outer, and it is quite probable that with unfuvorable conditions the former may not be used as a marsupium.

Besides these there are a few aberrant forms which may be, as Wetherby has suggested, "geological remnants," such as Unio phaseolus Hild., U. irroratus Lea, and $U$. cormutus Bar., having remarkable modifications of the branchial uterus or marsupium. These three species will probably have to stand as the types of as many genera.

But little is known concerning the anatomy of the foreign Unios. The soft parts of all the European species have been examined, I believe, and descriptions which go into the minutire, so far as color and trifling peculiarities of form are concernerl, have been published, but which give no idea of vital characters or structure. From all that I can learn the anatomy of the European forms is very much like that of the circumboreal Unio maryaritiferus, which is nuch like that of Unio gibbosus, crassidens, tetralasmus and the like. Of the Oriental and African forms I know almost nothing. I have examined the soft parts of gravid specimens of Unio gabonensis Kuster from Tropical West Africa, and found that in them the embryos filled the inner branchix alone.

It has been surmised that there was a close relationship between the Australasian Unios and those of South America. The shells of the species of the two faunas agree very closely in all characters; in being destitute of rays, and having a uniform olive-green epider- 
mis and a slightly concentrically sculptured surface, simple outlines, rather dull, bluish-white nacre, compressed cardinals and imperfectly radial beak sculpture. Lea examined gravid specimens of Unio peculiaris Lea, and firmus Lea from South America, and found that only the inner gill was filled with embryos. Suter reported the same thing from an examination of Unio menziezi Gray from New Zealand. I recently received some fine alcoholıc specimens of that species from him, and on examining them found, to my astonishment, that they agreed with Lea's descriptions of the soft parts of the South American forms as exactly as if they were the very animals that he had described. In all three species the outer gill is greatly produced below in the middle, the anal opening is destitute of papillæ, and there is no super anal opening at all, characters which are conspicuous in the South American species. I had previously placed these Australasian and South American Unios in a subgenus by themselves, for which I used the name Liplodon, applied by Spix to some Brazilian forms, ${ }^{6}$ but I am satisfied that they are entitled to generic rank, and Spix's name may be used for the group. I do not believe that they belong to the same phylum with the Unio gabonensis which, from conchological characters, seems much more closely related to the forms of Soutliern India. This seems to add another link to the chain of evidence which goes to prove a relationship between the faunas of Australasia and South America, and it is a question whether this relation came about on account of migration, by way of an Antaretic land way from one continent to another, or whether the two faunas are remnants of an earlier and generally distributed northern faun that was driven south and superceded by more modern forms. The Unios of South America and Australasia are simple forms, both anatomically and conchologically. Long ago Ihering predicted that the earliest Unios would be found to have radial beak sculpture; and two of the fossil species recently described by the writer from what are supposed to be the Triassic freshwater beds of Texas have that which is strictly radial. In the Australasian and South American forms the beak sculpture is imperfectly radial, the central rays curve together and generally coalesce, and in some

${ }^{6}$ The Classification and Geographical Distribution of the Pearly Freshwater Mussels. Proc. U. S. Nat. Museum, XVIII, 1896, p. 302.

${ }^{7}$ Description of Four New Triassic I'nios from the Staked Plains of Texas. Proc. U. S. Nat. Museum, XVIII, 1896, pp. 381--385. 
cases they are slightly broken. In some of the Indian and African forms this sculpture becomes irregularly rayed and zig-zagged; in the European forms it becomes somewhat concentric and often broken, while in Lampsilis we have the farthest departure from the simply radial, that is, the rays are all looped and joined in the center, where they are drawn up towards the beak. 'This genus lias without doubt the most highly developed animal of any of the Unios, and is, in all probability, the most modern. I have seen no extinct forms which certainly belong to it, and it was probably developed in North American waters, to which it is still confined.

\section{ISAAC LEA DEPARTMENT.}

[Conducted in the interest of the Isaac Lea Conclological Chapter of the Agassiz Association by its General Secretary, Mrs. M. Burton Williamson.]

COLLECTING IN MONTEREY BAY.

(Extract from the report of Mrs. E. H. King. From the Transactions of the Isaac Lea Chapter for I896.)

In the month of September I spent two weeks at Monterey Bay, and collected shells on about three miles of shore-line, rocky headlands and sandy beaches. Along the shore I found many patches of soil literally packed with fossil shells. In the black soil they are soft and crumple easily, but in the sand hills near the light house they are quite firm. Haliotis rufescens Swains, is the most abundant, but there are also great numbers of $H$. cracherodii Leach, and a variety of limpets; also Chlorostoma funebrale $\mathrm{A}$. Ad. I found in the sand hills a large perfect shell of Purpura canaliculata Duclos, much larger than any of the live shells I have seen.

We go down on the rocks as the tide goes out, take our lunch with us, and work until the tide rises and compels us to return. The first shells we find are the Littorinas, so very plentiful that large spaces and crevices are full of them. Two species abound L. planaxis and L. scutulata. There also the limpet appears, Acmec spectrum is the highest, but is also found low down, and larger near low water. Next were Acmoca patina Esch., and A. scabra Nutt., then appears $A$. persona and $A$. pelta Esch. Lottia gigantea Gray, is very near low water mark, and a few large specimens of nearly all the others, the lower on the rocks they were the larger were their thin shells. Here also I found a few shells of Gadinia reticulata Sby. 
Ácmcea asmi was numerous on Chlorostomas. A. mitra Esch. and A. rosacea $\mathrm{Cpr}$. were found on the sandy beaches.

Monoceros lapilloides Conr., are quite abundant in the crevices of rocks constantly washed by the tide, and in the same localities a few M. engonatum Conr. Here also in the roaming breakers were large quantities of Purpura saxicola Val. There seem to be three well defined varieties, white with many large varices, almost black with small varices, and smooth with bands of brown. Among the rocks and in little pools of water were large quantities of Chlorostoma funebrale A. Ad. They seem to be of two varieties, one plain and smooth and the other with a crinkled band around the body-whorl. The latter most abundant and largest in size. Chlorostoma brunneum Phil., is in the same locality but not nearly so numerous. Many of the C. brunneum are dead shells inhabited by the hermit crabs. In the same pools were Calliostoma costatum Mart. but numbers of them dead and the hermit crab in possession of the premises. A few $C$. canaliculatum Mart. and C. ammulatum, were also found but they were not such fine shells, as those washed upon the shore by the storms of winter. Low down on the rocks in the roaring waves were found some Haliotis cracherodii and some fine sea urchins. With the Haliotis we found a large beautiful Rupellaric lamellifera Conr. The mussels are very abundant in some places, literally darkening the rock. I think I found four species; Modiola modiolus I., $\boldsymbol{M}$. recta, Mytilus edulis and Mr. californianus Conr. Crepidula adunca Sby., was very abundant on the shells of Chlorostoma and C. navicelloides Nutt. in the apertures of dead shells. I found a number of Chitons but have not yet been able to classify them.

On the beaches I found many species of shells that I have never found alive, Olivella biplicata Sby., Conus californianus Hds., Nassa mendica Gld., Amphissa corrugata Rve., Astyris gausapata Gld., Marginella jervettii Cpr., Lacuna unifasciata Cpr., Bittium quadrifilatum Gld., and many others.

On the large beach at Monterey I found many rocks containing dead shells of borers, Parapholas californica and Pholadidea penita. In deep quiet pools at Point Pinas I found beautiful starfish. Some of a deep orange color, others dark red, some dark purple, others pale yellow. I saw some beautiful Anemones differing from any I had seen, they were eight or ten inches in diameter, and beautifully iridescent, the play of colors resembling a great opal with greenish lights. The holidays ended, and reluctantly I said good-bye to the beautiful bay. 


\title{
The Nautilus.
}

VoI.. XI.

JULY, 1897.

No. 3.

\section{SYNOPSIS OF THE PINNIDE OF THE UNITED STATES AND WEST INDIES.}

\author{
BY WM. H. DALL.
}

In revising the Tertiary Pinnide it became necessary to examine the recent species and their synonymy. As certain changes in the accepted nomenclature appear necessary, the following synopsis may be useful.

Family PINNID E.

Genus Pinva Linné, 1758.

Valves medially sulcate.

Pinna rudis (Linné) Chemn., ( + pernula Reeve non Chemn.); Bermuda, Bahamas.

Pinna carnea Gmelin, ( + pernula Chemn. non Reeve; + degenera Link, 1807; + fabellum (Lam.) Reeve, 1858; + varicosa (Lam.) Orb., 1853 ; + ? bullata (Swains.) Reeve, 1858).

Florida Keys, north to near Hatteras and south to Trinidad; also in the Red Sea.

\section{Genus Atroina Gray, 1847.}

Valves entire.

Atrina rigida Dillwyn apud Solander, 1817, $(+$ pectinata Born non Linné; + seminuda Lam., 1819, non Reeve; + altu Sby., 1835; + subviridis Reeve, 1858; + dorbiguyi Hanley, 1858; + carolinensis Hanley, 1858; + ramulosa Reeve, 1858; + seminudu Holmes, 1859 ; + muricuta of Anerican authors, but not of Linné or Reeve). 
Cape Fear, North Carolina, to the northern shores of South Anerica.

Atrina serrata Sowerby, 1825, ( + squamosissima Phil., 1849; + seminuda Reere, non Lam.; + muricatu Holmes, non Linné or Reeve; + seminuda of American authors, not Lam.).

Cape Hatteras, North Carolina, to Guadeloupe, West Indies.

The type of serrata was a very young shell with finely dereloped sculpture. The true Pinna muricata (L.) Reere, is probably an Oriental species, it is not at present known from America.

\section{ON TWO SO-CALLED "BULIMI" FROM THE NEW HEBRIDES.}

BY C. F. ANCEY.

Several years ago, Dr. Wm. D. Hartman described and figured two very interesting land shells from Segon Island, New Hebrides Archipelago, under the names of "Bulimus" ruga and "Bulimus" Bernieri. The English diagnoses and illustrations of these appeared in the Proceedings of the Academy of Natural Sciences of Philadelphia, 1890, page 284, plate III, figs. 1 and 2 . These shells were until quite recently known to me from the figures and descriptions quoted above, but I succeeded when in Paris in December, 1896, in procuring specimens. My opinion was they were not at all "Bulini" as suggested by Dr. Hartman, but modified forms of the Diplomorpha type. I now think there can be but little doubt they belong to the latter genus. The texture of shell, outline and external characters are not dissimilar, and in the best preserved specimens of Diplomorpha ruga and bernieri both have the throat tinged with blood-red color as in the typical $D$. layardi, although the describer mentioned the fuct in une of them only. No epidermis remains on the shells, not very numerous indeed, observed by me, but it nua be rery deciduous, and its absence gives the shells a rough and uneven appearance. I am indebted to $\mathrm{Mr}$. $\mathrm{Ph}$. Dautzenberg for a nice example of bernieri, and the shell is somewhat strawcolored like ruga. Of the latter, I procured two specimens, ne much larger than the type, the other, on the contrary, considerably snaller. The parietal denticle is wanting in the species under consideration, as well as in Diplomorpha delatouri.

Segon Island, the locality where rnga and Bermieri were found, is, I believe, in the Espiritu Santo group, that is, in the northern 
portion of the Archipelago, but is not on the maps accessible to me.

Mr. Crosse, in his recent paper on the New Caledonia land and freshwater shells published in the "Journal de Conchyliologie," said that "Helix" singularis and its allies, represent in that fauna the New Hebrides Diplomorpha, but I fail to detect so great an analogy. It is right to observe, by the by, that singularis is really found on Aneitum, one of the New Hebrides; Mr. E. L. Layard sent me two specimens from there, much snialler than any one I ever saw from New Caledonia, but otherwise quite the same. I must add that the true Pseudopartula (ty pe Helix galericulum Mousson), has nothing to do with this Melanesian group, and are evidently related to Amphidromus. Montrouzier's name Draparnaudia should be applied to singularis and sinistrorsa. The affinities of the genus are difficult to state until the soft parts are examined.

I avail myself of the opportunity of adding three species to the list of New Caledonian species of Mr. Crosse who certainly overlooked them, viz., Helicina neloueensis, bourailensis and saxoniana, all of Hartman.

\section{A NEW CANCELLARIA FROM THE ALABAMA EOCENE.}

\section{BY 'T. H. ALDRICH.}

Cancellaria lanceolata n. sp.

Shell elongated, whorls seven, first three nuclear and smooth, the others cancellated and having three strong revolving lines, the mid-

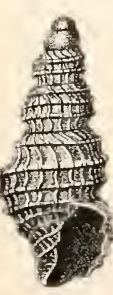
dle one much the larger, the costæ numerous and fine. Whorls are shouldered, suture deeply marked; body whorl with seven or eight revolving raised lines. Aperture oblong, outer lip serrated by the raised lines, nearly smooth within. Columella lip without callus, bearing two or more folds, part of the raised lines passing into the aperture to form them ; canal short, oblique, slightly twisted, no umbilicus. Length $7 \frac{1}{2}$, diam. $3 \frac{3}{4} \mathrm{~mm}$.

Locality.-Choctaw Corner, Ala. Woods Bluff horizon.

This little shell has some resemblance to C. pulcherima H. C. Lea, but Mr. C. W. Johnson, of the Wagner Free Institute of Science, has compared the two and finds the above distinct. The 
specimens are not fully matured. One of the two specimens has been presented to the "Lea Collection," in the Academy of Natural Sciences of Philadelphia.

\section{ON A COLLECTION OF MOLLUSKS FROM GRAND TOWER, ILLINOIS.}

BY FRANK C. BAKER.

During the latter part of April and first part of May, Mr. Frank M. Woodruff spent two weeks collecting birds in Jackson and Union Counties, Illinois, and incidentally picked up a number of mollusks, and the general conditions of the locality, and the small number of shells collected seem to warrant a few notes. This locality is situated on the Mississippi River, north of Big Muddy River, in the southwestern part of the State.

Of the localites visited Mr. Woodruff says: "The shells were found in a rocky glen or cleft in the center of the chain of high precipices known by the names of Fountain Bluff, Devil's Bake Oven and Backbone. This cleft or ravine begins about three-quarters of a mile from the face of the cliff and gradually descends in a northwesterly direction until the bottom is reached, and one nay stand upon a broad shelf of rock ten feet from the ground, with high overhanging cliffs of bare rock on both sides. A strean of clear spring water flows down this ravine and falling over the higl shelves of rock has formed numerous round pools or basins. I was surprised to find no shells in the stream, and could only collect a few specimens of Limnca humilis, which I found clinging to the wet moss under the falls. The balance of the shells were found under the moss and old logs at the base of the cliff. Fountain Bluff is tive miles from the town of Grand Tower, and is three miles long from north to south and about one and a half miles wide. According to Worthen's Geology of Illinois, the Backbone or ridge is formed by an uplift of Devonian strata which is tilted to an angle of about $25^{\circ}$, and dips to the northeast. The bluffs consist of Chester limestone and sandstone overlaid by conglomerate. 'The top of the bluff is covered with a rich growth of timber, among which are Willow, Sweet Gum, Qupelo tree, Sycamore, Cottonwood, Honey Locust, Hock Berry, Box Alder, Red Birch, White Ash, Black Ash, Red Oak, Mulberry, Persimnon, White and Black Oak, etc., are the most common." 
Thirteen species were obtained, and may be noted as follows:

1. 'Circinaria concava Say. A number of large and typical specimens of this species were collected and kept alive for a long time on the writer's desk. On May 18th two individuals were noted in coitu, the coitus lasting from 8 o'clock A. M. to 6 o'clock P. M. During this time both animals were perfectly quiet, the eye peduncles and tentacles drawn into the head and the foot contracted to form a rounded oval. During the coitus the heart, which normally beats about 75 times per minute, was reduced to 19 rery slow and long beats. The foot of the snail taking the active part was partly covered by the passive snail, and the former's head was slightly lifted. The specimens measured about 15 mill. in greatest diameter.

2. Vitrea arborea Say. A few specimens of this species rere obtained under and in rotting logs. All were perfectly typical.

3. Omphalina fuligrosa Griffith. The specimens obtained were rather dark in color and about half grown, the umbilicus wide and deep.

4. Polygrra (Mesodon) albolabris Say. But a single specimen of this species was obtained alire, and that was very large, measuring $34 \mathrm{mill}$. in greatest diameter. 'The animal was kept in captivity for several weeks, and was more active than any of the other species of Mesodon that the writer has studied. It wasstarted at the bottom of a book case door four feet long and reached the top in about half an hour. The examination of the lingual membrane gave $45-1-44$ teeth with ten perfect laterals. In this meinbrane the 38 th tooth was abnormal in having three well formed cusps of equal size, instead of a bifid inner cusp.

5. Polygred (Mesodon) exoleta Binney. Several typical specimens of this species were collected, among which there was one without the parietal tooth. The lingual membrane of one specimen gave 47-1-47 teeth with eight perfect laterals. The marginals were very variable, some being with and some without side cusps. It is probable that several teeth were torn away from this menbrane, although there could not have been the normal number given by Biuney, 60-1-60.

6. Polygira (Mesonon) thriroides Say. All specimens were of the nornal form.

${ }^{1}$ For the change in names of several of the genera and species here listed, see Pilsbry, Proc. Phila. Acad., 1894--97, where adequate reasons are given. 
7. Polygyra (Triodopsis) tridentata fraudulenta Pilsbry. A single specimen of this subspecies was collected by $\mathrm{Mr}$. Woodruff. Its radula differed considerably from that given in Binney's Manual of American Land Shells (p. 292), where 40-1-40 teeth with 12 perfect laterals is given. The present specimen had 27-1-27 teeth with 11 perfect laterals. The 17 th tooth had a bifid inner cutting point, but all before it were simple. The 13 th tooth showed a decided modification. The jaw was as usual, with 12 rather stout ribs.

8. Polygyra (Triodopsis) inflecta Say. The specimens collected were of the usual form.

9. Polygira (Stenotrema) yonodon fraterna Say. The specimens examined had 31-1-31 teeth on the lingual membrane with 10 perfect laterals, and the 13 th tooth had a bifid inner cutting point.

10. Polygyra (Stenotrema) hinsutum Say. The specimens obtained were of the normal form. One specimen measured $8 \frac{1}{2}$ mill. in greatest diameter. The radula was as given by Binney, 22-1-22 teeth with 10 perfect laterals, and the jaw had eight ribs.

11. Pyramidua alternata Say. The specimens collected are rather coarsely striated (or ribbed) and approach var. mordax Shuttl., but the ribbing is not quite as strong as in that variety.

12. Pyramidula perspectiva Say. Among the specimens obtained was one measuring 10 mill. in greatest diameter.

13. Limnea humilis Say. A number of specimens were collected in the moss under a waterfall. Mr. Woodruff reports finding all the speciniens out of the water.

It was remarkable that so few species of mollusks were found, and also that the species were so few in individuals. Mr. Woodruff says that a part of the region is made up of sandstone and conglomerate, and this may account for the great paucity of molluscan life. Mr. Woodruff searched diligently many times, particularly for the smaller forms, and states that at no time did he find more than one shell at one time, all seeming to live solitary lives.

\section{ISAAC LEA DEPARTMENT.}

[Conducted in the interest of the Isaac Lea Conchological Chapter of the Agassiz Association by its General Secretary, Mrs. M. Burton Williamson.]

Through the courtesy of Mr. Herbert Lowe, the writer had the pleasure of meeting our former member, Mr. Edward W. Roper of 
Revere, Mass. Mr. Roper is now in Pasadena, Cal. He was one of the founders of our chapter. One of his contributions to the Transactions of the chapter in its early days was an interesting paper on "Studies in the Genera Sphrerium and Pisidium," in 1889.

Mr. J. J. White, of Rockledge, Florida, has gone to Frankfort, Mich. for the summer months. The Vol. of Transactions should be sent to him at the latter address.

One of our valued members, in a letter, tells of a unique way in which devilffish are cauglt by some foreigners. The following is an extract from the letter, written from San Diego County, Cal.; " We met two men and a woman, apparently Portuguese and from La Playa, who were making a collection of deril-fish. One of the men carried a pail of lime water, and when they came to a devil-fish residence, he would pour half a pint or so of the lime water into the hole, and await developments. And they would come every time, too. It would be a very short time till the devil-fish would come squirming out of his hole, to get away from the lime, and be picked up by the men, thrown down on the rocks two or three times, until he was partially stumned, and then put with his fellows in a pail carried for the purpose. We watched the proceedings two or three times, and G. asked what they were going to do with them; 'eat them, they are fine,' was the astounding answer. It sounded like the biggest kind of a joke, but the people did not look or act so." As the Chinese are said to eat these mollusks there is no doubt they were in earnest. How they could locate the Octopus in each lole, is, to the writer, a mystery.

FLORIDA SHELLS.

[Extract from the report of Mr. J. J. White. From the Transactions of the Isaac Lea Conchological Chapter for I896.]

Business calling me to Miami and Palm Beach in July, I deternimed not to let so fine an opportunity for collecting pass without improving it. After concluding my business at Miami and Cocoanut Grove, I started out to hunt for the beautiful Orthalicus undatus Brug. and Liguus fasciatus Müll., but much to my regret was soon compelled to stop my search on account of the myriads of mosquitoes which infested the dense hummocks in which I was searching. I only succeeded in finding three live Orthalicus and one dead Liguus and some live Helix varians. Hoping for 
better success I started out on the waters of Bay Biscayne, and was well repaid for doing so by discovering a colony of seventeen Pyrula papyratia. They were all moving along, a compact body, to the northward, and it was one of the finest sights I have ever seen while collecting. The animals were beautifully marked with crimson and brown spots. Their eyes were large and black, and their long, flat heads and necks were light gray. It seemed hard to have to take then from their native element and kill then for their shells.

Four very fine Cyprcea exanthema were found clinging to some mangrove roots, while close by on some rocks, several feet above the water, was a colony of hundreds of Tectarins muricalns and among them a handful of small Nerita versicolor. Already having a good supply of Tectarius at home, I only collected a few of the largest, and the Neritas. Littorina lineata covered the rocks everywhere, but I did not molest them. One very fine Arca noae was soon added to those already in the basket. Some fine Arca ponderosa were also found. Fulgur perversum, F. carica, $F$. pyrum were quite plentiful, but they were only small ones, so only a few of each were taken.

My time being limited, I had to get back to Miami to take the train for Palm Beach, on Lake Worth-Lake Worth being my old and favorite collecting place. It would be difficult to find a hetter collecting place, for its size, than the flats around Lake Worth Inlet. Lake Worth is a fine body of salt water lying parallel with the Atlantic Ocean, and separated from it by a narrow strip of land which, in some places, is only a very few rods in width. It is twenty-two miles long and averages from one-haif to three-quarters of a mile in width. The sands washing in from the ocean have formed a large flat inside the lake at the inlet, and it is there we do our collecting. I have spent many days there very profitably. In the two days, spent there in July I collected about three hundred Strombus pugilis in all stages of growth; Strombus accipitrimes, S. bituberculatus and $S$. gigas to lie had for the taking. I also found, in lim. ited numbers, Lucina tigrina, L. pennsylvamica and L. divaricata, Dosinia elegans, Dolium galea, Cassis canaliculatus, C. testiculns, Cardinm magnum and $C$. isocardia, while on every hand Nussu vibex, Cerithium minimum, C.muscarum, C. literatum, C. floridanum, Neritina virginea and Iphigenie brasiliana were found by the thousands.

On the rocks on the north side of the inlet were found numbers of Purpura hemastoma and $P$. hemastoma var. unclata. The rocks 
there are literally covered with Siphonaria lineolato and Littorint lineata. One thing was very noticeable to me while collecting there, and that was the great numbers of Strombus pugilis. While living on the lake for seven years, I only found six living ones in the lake, and now there are thousands. The largest, $S$. gigas, are fast disappearing.

While on the flats at the old inlet, one mile below the present inlet, I discovered a colony of Cerithium minimum which attracter my attention by their distorted growth, and I at once collected half a pint of them. The spot where they were located was somewhat higher than the main flat, and at low tide would be exposed for several hours at a time. Whether this exposure caused this strange growth, or some other condition of immediate surroundings, I am at a loss to determine. I took especial pains to examine those at the present inlet, and I failed to find the distorted ones there, although they, at times, are exposed to the sun at low tides.

I found some Calistas on the mud flats east of Pitt's Island, a mile north of the inlet, which were new to me. On sending then to Professor Pilsbry they proved to be Calista varians, and are said to be the first reported from Florida. Suites of these have been sent to the Academy of Natural Sciences at Philadelphia and to the Smithsonian Institution and to some members of the Chapter, and so the list was soon disposed of. I also found a nice suit of Venus cribraria, which was also given to the Smithsonian Institution. I came away from Lake Worth well pleased with the results of two days' collecting.

During the past year I have made thirty-seven exchanges with persons in all sections of the country, and have added four hundred and twenty different varieties to my collection. My correspondence with the members of the Chapter has been pleasant, and all the exchanges very satisfactory. (Mr. White's generous offer to send shells to the nembers of our Chapter was published in ThE N.AU. Tilus for February: By this time the stock would be exhausterl).

\section{NOTES AND NEWS.}

Sinistral Aipullaria.-It may be of interest to readers of the Nautilus to know that in the collection of Ampullaria of the Academy of Natural Sciences of Philadelphia, numbering about an hun- 
dred species, hut one sinistral individual was found, of the species A. conica Wood. It is a clearly defined Ampullaria, and could not be confounded with the genus Lanistes.-Jennie E. Letson.

Helicina Rabei, n. sp. Shell lenticular, acutely carinated lowconic above; yellowish-or fleshy-white or red variously banded and figured; surface finely sulcate spirally. Whorls $3 \frac{x}{2}$, flat above, the last convex below the acute peripheral keel. Aperture subtriangular, oblique, dark red within, at least in part; peristome well expanded, white; axial callous heavy, rugose, varying from dark reddish-brown to translucent white in color. Alt. 6.3 , greatest dian. 11, lesser $8.7 \mathrm{~mm}$. Another specimen measures, alt. 5\%2, diameters 9 and $7.5 \mathrm{~mm}$. Pelew Is. (Dr. Rabe). This acutely keeled and spirally lirate species is remarkably variable in coloration. Types, no. 68,854 coll. A. N. S. P., presented by Mr. John Ford.-H. A. Pilibry.

\section{RECENT PUBLICATIONS RECEIVED.}

Professor Wm. H. Dall's Report on the Mollusks collected by the Interuational Boundary Commission of the United States and Mexico, 1892-1894 (Proc. U. S. Nat. Mus., 1896, issued in 1897), is one of the most important documents yet published upon the inland mollusk fauna of the southwest. It treats of a region rarely visited by snail collectors, and consequently but little known, and places the conchology of the region on a solid basis. The region north of Mexico, between the Rio Grande and the Colorado, seems to be a prolongation northward of the fauna of the mountains of northern Mexico, rather than a southern extension of that of the Great Basin west of the Rocky Mountains. It presents features due to contributions from the Californian and Mexican regions, the latter predominating, with a few stragglers from the north. The plains are almost uniformly arid and frequently alkaline, and nearly all the Pulmonates were collected at the upper levels of the various mountain ranges near the boundary. Epiphagmophora extends into the region, being represented in Arizona and New Mexico by four species, of which two, arizonensis and hachitana are new. The Polygyra levettei groups proves to be prolific in species, five, of which four are described by Dall, being found. The classification of $\mathrm{H}_{0} \mathrm{lo}_{0}$ spira proposed in the last volume of The Nautilus is fully set forth 
and new species figured. Cionella lubricu and Pyramidulu strigosu are among the northern species occurring in the Boundary region. The discussion of the Boundary fauna is followed by an extended treatment of the Lower Californian Bulimuli, in which a number of obscure matters are righted. In conclusion is given a list of marine mollusks from the termination of the international boundary and from San.Clemente Island.

Evidence is adduced indicating that within comparatively recent geologic time, probably Post-Pliocene, Mexico has been almost insulated from the Continent north of it.

The Journal de Conchyliologie for April, 1896 (issuer about April 7,1897), contains an important article on Pleurobranchus and related genera, by Prof. A. Vayssière, of Marseilles.

Dr. R. Ellsworth Call has added a valuable paper to the scant literature of American cave faunas in his Notes on the Flora and Fauna of Mammoth Cave, Ky. (American Naturalist, May, 1897). The only mollusk found by him in the cave is a Carychium, considerably like C.exiguum, which he describes as $C:$ stygium. About 150 examples were collected in "Mammoth Dome," on the wet surfaces of old bridge timbers, which have been lying undisturbed for forty or fifty years.

Dr. Heinrich Simroth gives a preliminary communication upon Russian slugs, ${ }^{1}$ based upon the study of materials in the Zoological Museum of the Imperial Academy and the Senckenberg Musenm at Frankfurt. The Caucasus Mountain region is the district of greatest peculiarity, having a number of special types. Simroth truly says that for the satisfactory working out of the species and their inter-relationships, the investigation of the genitalia and intestinal tract suffice; but for the nnclerstanding of the genera and their phylogeny, the other organs, especially the heart, pallial region, kidney and lung must be examined, a condition very rarely fulfilled. The Testacellide and Arionidce are briefly commented on, and the following genera of Limacide noted: Agriolimax, Paralimax, Lytopelta, Gigantolimax, Metalimax, Monochroma, Parmacellu. Metalimax and Monochroma are new, the former near Puralimax, but differing in the male genitalia; the latter is near Limax, but the eye-retractor does not pass between brauches of genitalia,

${ }^{1}$ Annuaire du Mus. Zool. de l'. Lead. Imp. des Sci. de St. Petersburg, 1896. 
etc. It is hoped that nothing will hinder the timely completion of this important work.

Another thorough anatomical paper, "Beitrage zur Kenntniss der Coniden," by Dr. R. Bergh, has appeared (Nova Acta der K. Leop.Carol. Deutchen Akad. der Naturforscher, LXV, No. 2). It is a well illustrated work on the soft anatomy of one of the most prominent families of marine Gastropods, the Conida, which, like many other groups, has long been well known conchologically, but only slightly anatomically. C. Pealii is the only United States species investigated.

In their " Diagnoses d'Esp. Nouv. de Pélécypodes et de Gastéropodes" (Bull. Soc. Zool. France, 1897), by Ph. Dautzenberg and H. Fischer, a good many species from the eastern Atlantic dredged by the "Hirondelle" and "Princesse Alice," are described but not figured. Amphirissoa, Basilissopsis and Aliceia are new genera. Species of Turcicula, Cocculina, Cetoconcha and other interesting genera are included. Mons. H. Fischer seems to be following in the footsteps of his distinguished father. In M. Datutzenberg he has an experienced and able collaborator.

Mr. Charles Hedley has recently described and figured a second fine species of Thersites from New Gninea, T. septentrionalis. It is more elevated than T. broxdbenti, more like the Queensland $T$. etheridgei (Rec. Austr. Museum, III, No. 1). In conjunction with Dr. Arthur Willey, the same author describes a new Astralium of the subgenus Guildfordia, from New Britain. It is some $45 \mathrm{~mm}$. in diam., and resembles the well-known A. triumphans from Japan.

Messrs. Melvill and Ponsonby have contributed to the Annals and Magazine of Natural History for June, 1897, another article upon Land and Fresh Water Mollusca from South Africa. New species of Achatimu, Ennea, Pupa and other genera are described, and also a species of Hapalus, a Bulimoid group not hitherto found so fur south.

An interesting paper by Mr. Harold Heath (Proc. Acad. Nat. Sci. Phila.) demonstrates the possession of small but well developed tegmenta upon the valves of young Californian Cryptochiton Stelleri. There are also small "sutural tufts," homologous with those of Acanthochites. A good plate illustrates these and other features. 


\section{The Nautilus.}

NOTE ON LANDSHELLS FROM THE MALAY PENINSULA.

BY W. H. DALL.

The National Museum las received an interesting small lot of landshells from Dr. W. L. Abbott, collected in the vicinity of Prang, on the Malay Peninsula. One of them appears to be new, and particularly elegant. The others have been identified by the aid of Mr. Charles T. Simpson and Professor H. A. Pilsbry. The list is as follows:

Ariophanta retrorsa Gould.

Planispira hardouini De Morgan.

Hemiplecta Leechi De Morgan.

Macrochlamys resplendens Phil.

Macrochlamys diadema Dall, n. sp.

Helicarion lineolatus von Martens.

Amphidromus sinensis Benson, small var.?

Amphidromus xiengensis L. Morelet.

Amphidromus sp. indet. (immature).

Cyclophorus Nevillei von Martens.

Cyclophorus Pfeifferi Sowerby.

Cyclophorus Cantori Benson.

Leptopoma vitreum Lesson.

Vivipara quadrata Benson.

Nanina (Macrochlamys ?) diadema n. sp.

Shell translucent yellow-brown, polished, depressed, with six and a half whorls, of which the apical two and a half are pale and smooth, the remainder show a deeply channeled suture outside of 
which the whorl rises abruptly, its rounded crest cut into rounded nodules like the joints of a millipede by deeply incised lines in harmony with the lines of growth; there are about 38 of these divisions on the last whorl ; the incisions override the crest and extend nearly to the periphery, becoming gradually fainter; periplery and base marked only by incremental lines, rounded, witl a minute perforate umbilicus, over which a small portion of the inner lip is bent; peristome thin, sharp, the body slowing hardly any callus; max. diam. 16 , min. diam. 13 , alt. $10 \mathrm{~mm}$.

This elegantly sculptured species seems to differ much from any yet described. Its nearest relatives are $\boldsymbol{M}$. complurialis Blanf., and 11. convallata Benson, which have a channelled suture, but do not have the transverse sculpture cutting the crest of the enclosing whorls. The types are in the National Museum.

\section{ON A NEW HOLOSPIRA FROM TEXAS.}

BY W. H. DALL.

Holospira (Haplostemma) Hamiltoni n, sp.

Shell slender, polished, spindle-shaped, pinkish-white, with a darker livid apex, and about 13 whorls; nucleus blunt, smooth, later three whorls delicately obliquely striated, central whorls smooth, last whorl with delicate oblique riblets with wider interspaces; aperture projected, rounded, subangular at the right posterior corner, the lip entire, reflected, the pillar rather wide; the last whorl flattened and attenuated. Lon. 19, max. diam. $5 \mathrm{~mm}$.

Collected in the Rio Grande Mis., Brewster Co., Texas, at a height of 3,500 feet, living on Selaginella lepidophylla Spring, by Mr. James M. Hamilton, and presented to the National Museum through Dr. R. W. Shufeldt.

This species is very much like $H$. (Metastoma) semistriata Stearns, externally, differing in its smaller and more slender shell and finer and more delicate sculpture of the later whorls near the aperture.

\section{QUARTER-DECKS AND JINGLES.}

BY ROBERT E. C. STEARNS.

Several years ago, in the course of a conversation with Captain J. IV. Collins, of the U.S. Fish Commission, relating to the various 
materials used by the oyster planters for collecting the spat or forming spawning-beds, certain shells were mentioned by him that were systenatically collected and sold to the oystermen. These shells were locally known by the names given in the above title. On looking into the matter, the "Quarter-decks" proved to be Crepidula fornicata Linné, and the "Jingles" a species of Anomia, presumably $A$. simplex Orbigny. As popular names go, these are not so bal, for there is a peculiar jingle produced by Anomia valves when many are shaken together, and the septum in Crepidula considered in connection with the boat-like shape of the species, $C$. fornicatu, suggests a partially decked vessel.

The abundance of these forms in the region referred to, is indicated by the following data kindly furnished (July, 1889) by Dr. H. II. Smith, of the Fish Commission, on "The Fertilization of Certain Shell-fish at Greenport, N. Y., locally known as 'Jingles' and "Quarter-decks.'”

Since 1880, these shells have been extensively used for the purpose of forming spawning-beds for oysters, the idea of so employing them having originated with Captain James Mousell, of Greemport. The shells are taken with dredges between the first of October and the first of July, and are sold by the fishermen to dealers at the rate of four cents a bushel. At times they bring more, according to the demand. A law prohibiting the taking of them between the first of July and the first of October went into effect in 1888. The shells lie on the docks until July, when they are taken to the planting grounds and sold to the oystermen. Unlike the scallops used for the same purpose, the jingles and quarter-decks are not opened when caught.

The Crepidulus or quarter-decks being gastropods (univalves), no opening is possible, and the two pieces or parts of the bivalve Anomias or jingles, readily separate when dead and dry. The scallop or Pecten shells ( $P$. irradians Lam.) are opened in order to extract the meats, the sales of which yielded the men engaged in the scallop-fishery of Massachusetts, Rhode Island and Connecticut, principally the two first States, in the year $1892, \$ 114,695$, the product of 137,284 bushels of this species of Pecten. The emptied shells, a residual product, are utilized as before indicated.

"Investigations by an agent of the U. S. Fish Commission show that in 1887 there were taken 130,000 bushels of 'quarter-decks' and 'jingles' valued at $\$ 5,200$. In 1888 the output of the fishery 
was 110,000 bushels, valued at $\$ 4,400$, while the catch in 1889 , up to and including the 19 th of June, was 75,000 bushels, valued at $\$ 3,000 . "$

The marvellous abundance in certain localities of the various species above named, is, aside from the economic value of the fishery, of exceeding interest to the naturalist. What proportion of the total quantity, 315,000 bushels of jingles and quarter-decks, belong to the latter species, Crepidula, is not stated; probably much less than half, and quite likely not more than a quarter; presumably the quarter-decks are attached to, or are adherent upon, the jingle or Anomia shells, domiciliares upon the valves of the latter species, the same as the West American species.

Crepidula rugosa is a domiciliare on the shells of Pecten cequisul. catus Cpr., the Californian analogue of $P$. irradians. It is not at all infrequent to find from three to six individuals of the West Coast Crepidula on a single specimen of the Pecten.

Beside the use of oyster, clam, scallop, quarter-deck and jingle shells for forming spawning-beds, the oystermen in some instances and in some places, are utilizing old tin cans as catchment objects for the spat to fasten upon. What with the packing of adult oysters at the canneries and the entrapping of the innocent unsophisticated fry on old tin pots and cans, the situation may be said to look to an old man in a balloon, or a young wan "up a tall tree," like canning the oysters at both ends.

Los Angeles, Cal., June, 1897.

\section{NEW UNIOS.}

BY BERLIN H. WRIGHT.

Unio Pinei sp. nov.

Shell wide or oblong, moderately and uniformly thin, dorsal and ventral margins usually parallel, subtruncate or obliquely rounded before, biangular and truncated behind. Epidermis reddish-brown; olive above, polished and thickly covered with unequal rays. Beaks scarely elevated above the dorsum, and surrounded by four or five fine concentric, undulating ridges. Ligament thin, reddish, long and depressed. Greatest diameter in the centre of the shell. Beak cavities slight. Cavity of the valves ample and tray-shaped. Nacre 
brilliant and copper-colored, very iridescent and remarkably coruscated; the upper third being stained darker. Lateral teeth equal, long, slender, slightly curved and extending fully to the cardinals. Cardinal teeth inclined to be double in both valves, compressed, oblique and serrulate. Cicatrices well impressed, showing the prismatic layers, the anterior ones being roughened in the posterior portion and widely distinct, and the posterior ones confluent. Pallial lines obscure. Dorsal notch long and shallow. Width 3 inches, length 1.5 inches, diameter 1 inch.

Habitat.-An unnamed lake in Witthacoochee River region of Hernando Co., Florida.

Type in National Museum.

Remarks.-It is difficult to assign a place to this shell, partaking as it does of the features of several members of the Buckleyi group. It has the subtruncate anterior of $U$. coruscus Gould, and approaches that species in nacre, which in our shell is of a deeper and richer tint, and is not so pointed behind, is more inflated, straighter dorsum, lighter teeth, more rayed and has a red instead of a blackirh epidermis, and attains a much greater size. From U. Hinkleyi B. H. W., it differs in the abrupt anterior, sides more rounded, darker nacre, and in the reddish, instead of black epidermis. It is in every way more gracile than $U$. Buckieyi Lea, and is not so pointed behind. Nor has it the ponderous umbos, arched dorsum and rounded base of that species.

Sixty specimens of all ages have been observed, showing a remarkably perfect uniformity of characters. It is named for the discoverer, Mr. George Pine, of Aripeka, Hernando Co., Florida.

(To be Continued.)

MELANIA YOKOHAMENSIS, N. SP.

BY W. D. HARTMAN.

Shell elongate, conic, gradually tapering to an acute apex. Whorls 7, suture lightly impressed; surface smooth, with obscure spiral lines, color yellowish-green; aperture white, opercle brown, oval and corneous. Length 35 mill., width 13 mill.; width of aperture 6 mill., length of aperture 10 mill.

Locality.-Yokohama, Japan, B. Schmacker collector. 
This shell was giren me by Mr. Schmacker sereral years ago. Some sent Dr. Brot, of Genera, were pronounced new at the time.

\section{ISAAC LEA DEPARTMENT.}

FConducted in the interest of the Isaac Lea Conchological Chapter of the Agassiz Associaion by its General secretary, Mrs. M. Burton Wrilliamson.]

May 28th, the volume of Transactions was forwarded from San Diego east. Since that date the General Secretary has received no word regarding it.

SEEING EYES.

[From the report of Mrs. E. A. Lawrence. From the Transactions of the Isaac Lea Chapter for 1896$]$.

Lowell says, "Eyes are not so common as people think, or poets would be plentier," and, what he has said of poets, could be said with equal truth of naturalists. Nature, to ninety-nine per cent. of the human family, is a closed book, not because she is not willing to have ber pages opened, but because people have no eyes to see with. Thoreau could find in his back-door yard, or, on the shore of Waldon Pond, the material for printed volumes. It was not because these places had more of interest in them than similar places elsewhere, but it was becanse Thoreau had trained his eyes to see. How many people, of all those who yearly visit our sea-shore, have seeing eyes? They will tell us of the beauty of the foam-capped waves, or the brilliant tints of the water at sunset; but they will pass with unseeing eyes on careless feet over myriads of living creatures, creatures so wonderful in their mechanism, so beautiful in their form and coloring, and so cumning in their instincts, that they show to the observer the perfect workmanship of the great master, Nature.

A bout two years ago, I began to view the sea-side world through open eyes, and in that time I have collected over two hundred species of mollusea in the vicinity of San Pedro Bay. This past year I found beneath shelving rocks the little Megetabennus bimaculatus Dall, and nestling in hollows in the rough rocks I found a number of Gadinia reticulata Cpr.; the latter are so nearly the color of the 
rocks that it takes sharp eyes to discern them. Upon goose barnacles I found a small Acmac which I hoped might be a new species, but I found my eyes were not very wide open even after a year's experience in the opening process, for I sent the Acmoa to Dr. Dall and he said they were only a small variety of the $A$. pelta. But in classifying my shells I have made two varieties of them, as I think there is enough difference in them to warrant such division.

Going down on the sand one day at low tide, I saw a small uphearal of the sand, and since I have been travelling the world with seeing eyes, I always investigate these tiny mounds, and, this time, I was rewarded by finding a Tornatina culcitella, and a diligent search soon revealed several of these cunning little creatures. With these are $T$. inculta and $T$. carinatu. While out in a boat among the kelp I found a number of Lacuna unifasciata and some $L$, porrecta, these latter were three-eighths of an inch long. Among the tiny shells, seeing eyes are called into requisition, and I find the aid of a strong lens often necessary to bring out their distinctive features. The tiny Marginella (Volvarina) varia is more beautiful than a Cyprea spadicea, and yet the blind world never finds them hidden away under stones, and covered with their thin tents, which are quite a protection for them, as it hides their shining surface and makes them much less conspicuous. The Turbonillas, the Odostomias, the Mitromorphas and many others have en riched my cabinet, and opened my eyes to the wonders and beauty of small things this past year.

When I began to classify, I had many a struggle with the different autlorities, and many a dispairing appeal I sent to our General Secretary, who never failed to come to my relief, and I have much to thank her for, inasmuch as she has given me light where before I dwelt in darkness. * * * * To sum up the year's work, no greater gain has come to me than luas come by the opening of my eyes, and the knowledge I have gained by seeing. The earth has taken on new beauty and the sea has opened some of its wonderful storehouse and bidden me enter, and all nature beckons me with kindly finger to further discoveries by the aid of seeing eyes.

\section{NOTES AND NEWS.}

Nautilus pompilius ix Southern New South Wates. - What surprised me most was to find large numbers of rather brokell speci- 
mens of Nautilus pompilius thrown up in Eden Bay. It is difficult to conceive how they get there; it is an enormous expanse to be drifted away from any of the Pacific Isles. Can it be possible that they are eaten by whales and that the shells is extruded as excrement? I make this suggestion because great schools of whales come in there, it is said, to rub themselves on the coarse gravel bottom of the bay.-Di..J. C. Cox, in letter to Editor.

Partula: Notes and Correctrons.-Partula eximia Hartm. $=P$. macgillivrayi.

P. Brazieri Pse. is a good species.

The type example of Partula neweenitiarum was lost with the vessel on its return to Mr. Garritt at Tahiti.-W. D. Hartman.

A New Species of Hempribla, - In examining the slugs referred to Hemphillia glandulosa in the collection of the Academy of Natural Sciences, we found that two species have hitherto borne this name. The true $H$. glandulosa is a small slug, with distinctly papillose mantle; the pedal line hardly rises at the tail, and the caudal gland is surmounted by a conspicuous horn. The other form, which we call $H$. comelus, is much larger, the mantle is not papillose, and the pedal groove rises abruptly and conspicuously at the tail, and there is no noticeable hom there. Types from Old Mission, Idaho, collected by Hemphill. The species are easily separated by external characters, but the internal anatomy shows even more important differences, which will be described and figured in the second installment of our "Revision of American Slugs," now in preparation.-H. A. Pilsbry \& E. G. Vanatta.

\section{RECENT PUBLICATIONS RECEIVED.}

An apparently very thorough monograph of the Cephalopoda of the Gulf of Naples, by Guiseppe Jatta, has appeared in the "Fauna and Flora des Golfes von Neapel" (23d monograph). The illustrations are incomparably magnificent.

Mr. Felix Bernard ${ }^{1}$ has detected a stage of shell-growth in bivalves earlier than the prodissoconch, which he proposes to call protostracum. He finds the protostracum on the summit of the prodissoconch. The Glochidium stage in Unionide is its equivalent.

${ }^{1}$ Compt. Rend. Acad. Sci. Paris, Vol. 124, p. 1165 ; Natural Science, July, 1897 , p. 10. 


\section{A CLASSIFIED CATALOGUE OF AMERICAN LAND SHELLS, WITH LOCALITIES.}

BY HENRY A. PILSBRY.

Almost a decade has elapsed since the publication of the "Check List of American Land Shells" (Proc. Acad. N. S. Phila., 1889), and the frequent calls for copies of that list since the reprint edition was exhausted, as well as the progress of the science during that period, have induced the editors of The Nautilus to offer a new list covering the same ground.

In the nomenclature of this list we have admitted changes shown to be necessary; and in the classification have frequently forsaken the old roads for paths lately "blazed out," and as yet not much travelled.

Additions and corrections of any kind will be gratefully received.

$$
\begin{aligned}
& \text { Class GASTROPODA. } \\
& \text { Subclass Streptoneura. } \\
& \text { Order Prosobranchiata. } \\
& \text { Suborder Trnioglossa. }
\end{aligned}
$$

\section{Family CYCLOSTOMATID不.}

Genus CHOANOPOMA Pfeiffer, 1847.

Subgenus Ctenopoma Shuttleworth, Pfr., 1856.

1. Choanopoma bahamense Shuttl. Key West, Fla. (Dr. W. H. Rush). Also Bahamas.

Genus CHONDROPOMA Pfeiffer, $18 \pm 7$.

2. Chondropoma dentatum (Say). Key West and Naples, near Gordon's Pass, Fla. Also Cuba.

Family TRUNCATELLID丑.

Genus TRUNCATELLA Rišo, 1826.

3. Truncatella Caribæensis 'Sowb.' Rve. Key Largo and Anclote Key, Fla. Also West Indies.

4. Truncatella caribeensis pulchella Pfr. Marco and Cedar Keys, Fla. Also Bermuda, Cuba, Yucatan, etc. 
5. Truncatella bilabiata Pfr. Key West, Key Largo, Biscayne Bay, Micco, Indian River, Furguson's Pass, Marco, Cedar Keys, Fla. Also Bermuda, Cuba, etc.

6. Truncatella stmpsoni Stearns. False Bay, near San Diego, California.

7. Truncatella californica Pfr. San Diego, California.

[Note.-T. subcylindrica "Gray" has been reported from Florida. The identity of the species is doubtful, and the occurrence in Florida of the form so-called by Pfeiffer, equally so].

Suborder Rhipidoglossa.

Family HELICINID床.

Genus HELICINA Lamarck, 1801.

8. Helicina chrsocheila Binney. Texas, near mouth of the Rio Grande. Also State of Tamaulipas, Mexico.

9. Helicina orbictlata Say. St. Simon's I., Ga., Chattanooga, Tenn., Eureka Springs, Ark., Stone Co., Mo., southward to southern Florida, and southwest to the Rio Grande; type locality near mouth of the St. John's River, Florida. [H. Hanleyana Pfr. is a syno$11 \mathrm{ym}]$.

9a. Helicina orbiculata tropica 'Jan' Pfr. Texas, mainly south and southwest. An ill defined race.

10. Helicina occulta Say. Western Pa. to Minn., south to Tenn. Distribution markedly discontinuous and local. Allegheny Co., Pa.; Athens, Ill.; near Iowa City and Eldora, Iowa; Winona, Minu.; Sheboygan, Whitefish Bay near Milraukee, and near Du Pere, Tis.; Lexington and at Natural Bridge. Va.; Harriman and South Pittsburg, Tenn. An abundant fossil of the Post-Pliocene Loess formation in eastern and ceutral Iowa, the adjacent parts of Ill., western Ia. and E. Neb.; also fossil at New Harmony, Ind., the type locality.

[Note.-H. subglobulosa Poey, a Cuban species introduced into United States works on the evidence of specimens found at Key Biscayne and Fort Dallas, Fla., many years ago, has not yet been shown to be actually living in Florida].

Subclass Euthyneura.

Order Pulmonata.

Suborder Stylommatophora. 
THE NAUTILUS.

(Superfamily HOLOPOD.1).

Family HELICID压.

Subfamily Helicinæ (vel Belogma).

(Belogona Siphonadenia).

Genus HELIX Linné, 175 s.

Section Helicogena Férussac.

11. Helix Aspersa Müll. Charleston, S. C.; New Orleans; Santa Barbara, Santa Clara and San Jose, Cal. Imported from Europe.

$$
\text { Section Tachea 'Leach,' Turton, } 1831 .
$$

12. Helix nemoralis Limn. Burlington, N. J.; Lexington, Va.; ? Baraboo, Sauk Co., Wis. Imported from northern Europe.

13. Helix hortensis Müll. Labrador; Anticosti I.; Barachois, Gaspé region; Nova Scotia ; Casco Bay, MIe. : Eagle, House, Kettle, and Nantucket Is., Mass. ; also New Bedford, Marblehead, Manchester and Magnolia, Mass.

Genus HYGROMIA Risso, 1826.

Section Fruticicola Held, 1837.

14. Hygronid hispida (L.). Halifax, N. S.; Montreal. A species of uorthern Europe, imported.

15. Hygromia Rufescens (Penn.). Quebec and Levis, Quebec, Canada. A species of northern Europe, imported.

Genu: HELICELLA Férussac.

Section Trochula Schlüter, 1838.

16. Helicella terrestris (Penn.). Charleston, S. C. A native of southern Europe.

\section{Subgenus Cochlicella Risso, 1826.}

17. Helicella vevtricosa (Drap.). Sullivan's I., S. C. Imported from Europe.

Subgenus Theba Risso, 1826.

18. Helicela cantiaxa (Montagu). Quebec. A native of northern and central Europe. 
(Belogona Euadenia).

Genue GLYPTOSTOMA Bland \& Binney, 1s73.

19. Glyptostoma newberryanum (IT. G. Binn.). Los Angeles, Cal., to Todos Santos Bay, Lower Cal., and about 40 miles inland.

Genu: LYSINOE H. \& A. Adams, 1855.

20. Lysinoe humboldtiana (Val.). Altuda, Texas. Also Mexico.

Genus EPIPHRAGMOPHORA Doring, 1875.

Subgenus Monadenia Pilsbry, 1895.

21. Epiphragmophora fidelis (Gray). Humboldt and Shasta Co., C'al., to Vancouver I.

21a. Epiphragmophora fidelis, f. flava Hemph.

21b. Epiphragmophora fidelis $f$. minor.

21c. Epiphragmophora fidelis subcarinata Hemph. Humboldt Co., Cal. This is directly intermediate between fidelis and infumata.

21d. Epiphragmophora fidelis infumata (Gld.). Coast counties of (al. from Siskiyou to Alameda.

22. Eprphragmophora mormonum (Pfr.) Shasta Co. to Tulare and Santa Barbara Co., Cal.

23. Eptphragiophora hillebrand (Newc.) Calaveras, Tuolumne and Mariposa Cos., Cal.

24. Epiphragmophora circumcarinata (Stearns). Near Turloch, Stanilaus Co., Cal.

Subgenus Helminthoglypta Ancey.

25. Epiphragmophora dupetithouari (Desh.). Monterey, Cal.

26. Epiphragiophora sequoicola (Coop.). Santa Cruz Co., Cal.

27. Epiphragmophora a yresiana (Newc.). Santa Cruz, San Miguel, San Clemente and Santa Rosa Islands.

28. Epiphragmophora traski (Newc.). Los Angeles to Ft. Tejon and to San Luis Obispo, Cal.

28a. Epiphragiophora traski proles Hemphill. Fraser's Mills, Tulare Co., Cal.

(To be Continued.) 


\section{The Nautilus.}

BOLINAS, CALIFORNIA; THE CONCHOLOGISTS PARADISE.

BY WIMLIARD M. WOOD.

Aqui estoy otravez!

Once more I have reached the rocky shores of dear old historic Bolinas. I could never tear myself from this antique Spanish town by the Ocean. How I love to hear the mighty waves beat wildly against the solid rocks, and see the lofty yellow bluffs which rise so majestically from Neptune's euchanting liome.

Annually, during the summer months, I find that I am-like the proverbial Snail, wending my way, through exquisite redwood forests and inhaling the salubrious mountain air. The point of destination is alway Bolinas. Bolinas, thou art and ever shall be my Mecca.

This year, Mr. George E. Townsend and the writer concluded to pitch tent and camp upon one of the smaller bluffs, by the side of a delightful rippling creek, within a stone's throw of the beach which is used for bathing purposes, in lieu of making the hotel our headquarters during our stay. We also decided to "tramp it," and as each possessed a good pair of strong limbs, the start was made from San Anselmo Station, Marin County. The distance from the station to Bolinas is estimated at about twenty miles. Ten miles of this number is entirely devoted to up hill climbing, and so steep, that in portions where there is no shelter from the sun as it sends forth its penetrating rays, one becomes quite exhausted, especially when one is principally confined in a down town office, pondering over innumerable books and papers, and not used to mountain climbing. 
While going toward the "Summit," how truly beautiful were the rustic wooden bridges over which we passed, and the cool-looking, shaded, rainbow-tinted and trout ladened streams. How the saucy big blue.jays scolded when we ventured too close to their nesting places! Then there were numerous tiny golden-breasted wild canaries; how beautifully they did sing! The peacock-green throated humming-birds were busy flying hither and thither, abstracting the honey from the delicately scented flowers. Cotton-tails would occasionally be seen rumning frantically across the broad road and hiding among the heavy brush, so that they would unt fall victims to the many hawks and red-necked buzzards which appear at all times to hover overhead.

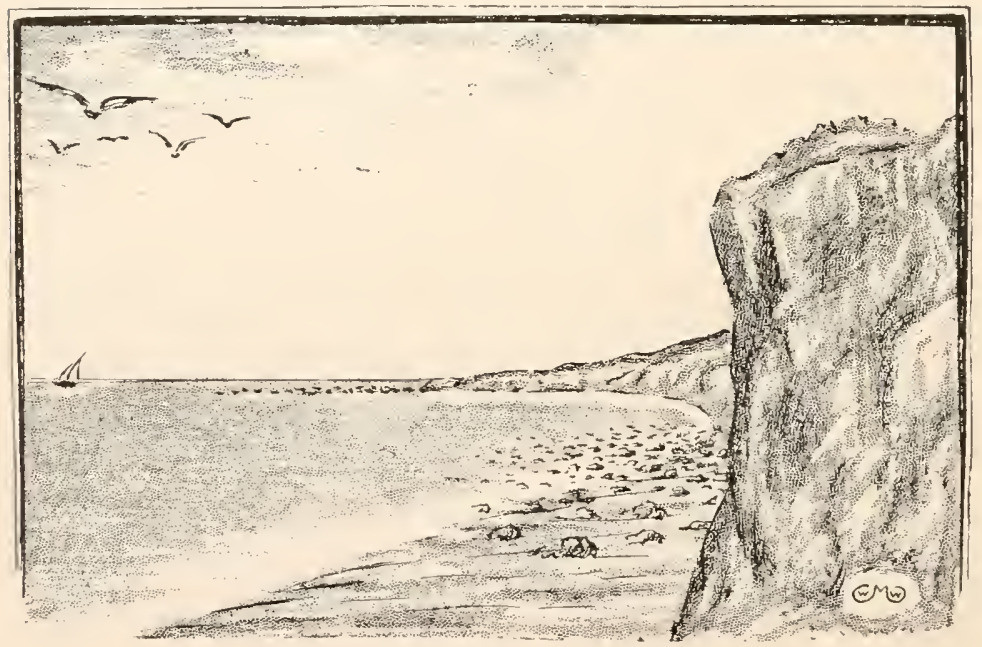

The beach, bluffs and Duxbury Reef.

Several times we came across a flock of mountain quail. The minute we were observed by them, they would take to the wing. The noise caused by their flying resembled greatly an immense buzz saw revolving with great rapidity and cutting through heavy timber.

When we reached "the ridge," we were rewarded by a superb view of the surrounding country. Not a particle of fog was within sight. The atmosphere was as clear as crystal. The view covered an expanse of scenery which could not be emulated for picturesque variety. Mountains, forests, lakes, valleys, rocks, straits and capes, cities, towns and villages spread themselves in a magnificent panorama. 
The ten mile descent of the mountain on its western side was comparatively easy as the road was in excellent condition. The weather has been delightful since we have been here and trust that it will continue so throughout our stay.

Although the ground on the mountain's side was quite dry, careful searching with the aid of a short limb of a tree, raking deeply among the fallen leaves, revealed to us, quantities of the following Helicies, all with the living animal within.

Helix arrosa, nicliliniana, Polygyra armigera and Selenites vancouverensis. No fresh-water shells were found in the streams and poots on the way over. In fact, I do not believe there are any in the vicinity of this place, for I have been unable to secure a single specimen during the past six years.

The tides so far, have been very good and several species have been added to my collection, which are entirely new to me.

The beach from the bluffs near the chamel (entrance to the Bay of Bolinas) out to the dangerous reef-Duxbury reef-is at intervals composed of billions of particles of shells, ground so fine that the casual observer would naturally suppose they were grains of sand. Certain spots I have seen on the beach are almost wholly composed of these diminutive bits to a depth of about five or six inches.

The reef upon which I had formerly seen attached thousands of immense Chlorostoma funebrale and fairly good sized Chrysodomus dirus are now almost destitute of the above named species. The reason of their disappearance is unknown to me. The species observed attached to the rocks and the blue clay at the present date are Monoceros engonatum and Litorina scutulata. M. engonatum predominating. Of Chlorostoma bruneum, I have gathered hundreds at previous visits, from a point just a short distance from the reef in a north-westerly direction. Not one in a living state have I found since arriving.

Strolling up the sandy beach in the early morniug, (4.30) until we reached the stretch of mossy rocks which had been left bare by the retreating tide, we secured dozens of the common edible clam, Tapes staminea, which is sold by the sackful in the markets of San Francisco. These were brought back to our camp and served at breakfast.

The Bay of Bolinas, which at one time was quite commodious, is now ahmost completely filled with sand and mud. The channel, no 
doubt will soon be closed and not even the smallest boat will be able to enter this once beautifully situated bay.

When low tide occurs in the bay, the "necks" of thousands of Schizothcerus Nuttalli may be seen projecting an inch or so out of the gray mud. Although the shells themselves are buried quite deeply under the surface, it is with difficulty that these hugh specimens may be obtained. Think of gathering clams almost the size of dinner plates. We managed to secure several splendid specimens. The "necks" when fully extended are about three feet long. It requires several persons with rubber boots, shovels and pails to "catch" one, as they will withdraw their " necks" quickly and bury themselves out of view and reach, if disturbed. The strength of one person is required to hold the neck on the surface while another person digs around it and bails out the fast in-coming mud and water. It is indeed hard work to capture one of then, but well worth the trouble and time spent over them.

The Bay also produces thousands of dead, yet fresh-looking specimens of Hacoma secta. These are found either upon the surface or an inch or two below, imbedded in the soft mud. Hundreds were secured and after having given them a thorough washing, they were packed away carefully in cotton batting.

Living Cryptomya californica in considerable numbers seem to be washed upon the mud flats. They range in size from a pin head to a quarter of a dollar.

When low tide occurs at the reef, one may dig in the clay for horers and be rewarded with several species. The clay is fairly alive with them.

Occasionally I have found cast up on the beach by the waters, fine examples of that immense "rock oyster" Hinnites giganteus. Several contained the living animal. One specimen picked up measures almost ten inches in diameter. Who says we do not have large oysters! The beach is covered with great numbers of worn valves. The young shells are easily mistaken for Pecten hastatus and I have often been fooled in this respect. Fresh, full grown specimens are very hard to obtain.

What do you suppose to-day-the glorious fourth of Julybrought forth? Two most interesting species that I have found up to date. I had not searched for these and they were entirely a surprise to me. Doubly welcome are my new friends on this day. We were sitting lazily upon the pebbly beach watching the waves as 
they washed upon the shore. Suddenly a larger wave than those which I had been accustomed to see, rushed forward and with a mighty splash, broke within a few feet of us. The water and foam crept so quickly in our direction that my shoes were soon filled with the cold sea-water. With a quick spring, I was upon my feet and hurrying from the scene of the unfortunate event. When returming to the spot where we had left a stick half buried in the sand, I came across unexpectedly two valves of Semele mbrolincatu and a most delicate and perfect fresh-looking specimen of Mytilimeria Nuttalli Conr.

How truly patriotic were the little shells to cone and cast themselves at my very feet, upon this eventful day. The rose colored radiations on the Semele were beautiful and looked like many skyrockets going heavenward.

Among the species collected which are not mentioned above, are as follows:

Acmoca asmi, mitra, patina, pelta, persona, spectrum, incessa, instabilis, Adula fulcata, stylina, Amphissa corrugata, Amycla carinata, Bittium filosum, Calliostoma costatum, Cardium corbis, Cerostoma foliatum, Chama pellucida, (valves only) Chlorostoma montereyi, Pfeifferi,? Crepidula adunca, navicelloides, Entodesmor saxicola, Lithophagus phumula, Fissuridea aspera, Haliotis fulgens, (large but poor specimens, washed ashore) Hipponyx tumens, Kellia Laperousii, var. Chironii, Lacuna mifasciata, Lazoria subquadrata, (valves), Litorina planaxis. Lunatia Lewisii, (half a foot in length) Lyonsia Californica, Macoma nasuta, inquinata, Siliqua patula, Mytilus Califomianus, Nassa fossata, Cooperi, Margarita pupilla, Ocinebra luridu, interfossa, Olivella biplicata, Petricolu carditoides, Pecten hastatns, (valves) Pholadidea penita, parva, Platyodon cancellatus, Parapholas californica, Placunanomia macroschisma, (valves) Purpura crispata, lima, saxicola, ostrina, Saxicava arctica, Saxidomus aratus, Tapes staminea, tenerrima, ruderata, Tellina Bodegensis, (valves) Zirphaca crispata, Cryptochiton Stelleri, (seven inches long) Ischnochiton Cooperi, Mopalia Hindsii and muscosa.

I have not gone carefully over the species collected-doubtless many others might be included in this list-but the above will serve to show the rich molluscan fauna of this certainly delightful peninsula. The territory worked over by me cannot be more than four miles square. The specimens collected alrealy number many thousands and the rate at which they are being gathered, who knows but 
it shall require the chartering of the small schooner now lying in the channel, to carry them down to the City!

Deseo que el lugar que ha sicto tan atractivo y productivo en lo pasado para el que se suscribe para siempre permanetea inmutable.

Bolinas, Cal., July tth.

\section{NOTE ON A CALIFORNIAN HELIX.}

BI HENRY A. PILSBRY.

In the "Manual of American Land Shells" Mr. Binney figured a shell from San Pablo as a form of "Arionta californiensis var. ramentosa Gld." It would seem that the same form has been subsequently described by both Dall and myself, although until recently collating materials for the new catalogue of U.S. land shells, I had entirely forgotten that I had ever noticed the form in question. The published references are as follows:

1885.- " A smaller form of this variety [i.e. ramentosa] from San Pablo," IV. G. Binney, Man. Amer. L. Sh., Bull. 28 U.S. Nat. Mus., p. 133, f. 108 (no description).

1895, Feb. 2.-Epiphragmophora californiensis v. contracoste Pilsbry, Guide to the Study of Helices, Man. Conclı. (2), IX, p. 199 (a nude name).

1895, Oct. 1.-Epip,hragmophore californiensis var. contracosto Pilsbry, Nautilus IX, p. 72 (description).

1896, A pr. 23.-Epiphragmophora Aruheimi Dall, Proc. U. S. Nat. Nat. Mus. XVIII, p. 6 (no description; refers to Binney's figures).

1897, Jan.-Epiphragmophora Amheimi Dall, Proc. U. S. N. M. XIX, p. 375 (full description).

As will be seen from the above, the form was recognized by myself in 1894 when reviewing the Helices for the "Guide" but the number in which the name appears although printed in 1894, was not issuerl until February, 1895, and it was in no way defined at that time; the brief diagnosis then prepared being overlooked for some months, finally appearing in October, 1895. I do not know when the form was first recognized by my friend in Washington, but from the notorious tardiness of the Proceedings of the Nat. Mus., and the fact that a partial abstract of Dall's article appeared in Naurius for Sept., 1895 , and was furnished by him a month or two 
earlier, it is likely that Prof. Dall recognized the form after the publication of the nude name in Man. Conch., hut before it was scantily clothed with a description in the October Nautuus.

Dall's first notice of the form referred merely to Binney's figures; but lately he has given an account of it which leaves nothing to be desired save an equally good notice of the soft anatomy.

\section{NEW UNIOS.}

\section{BY BERLIN H. WRIGHT.}

\section{Unio Buxtoni -l. nov.}

Shell very transverse or wide, subcylindrical, moderately and uniformly inflated, subsolid, bluntly pointed and attenuated behind, obliquely rounded in front and straight on the dorsum. Epidermis olive-black and obscurely rayed throughout. Growth lines obscure. Umbos depressed. Beaks pointed and very small, with two or three distant, nodose undulations. Umbonal ridge rounded or subangular. Beak cavities slight; cavity of valves ample. Lateral teeth straight, slender, thin and long, the inner one thicker and higher, and both extending to the cardinals, which are erect, short, with many curved ridgelets on the upper faces, double in the left and single in the right valves. Cicatrices slightly impressed but well defined, the anterior ones distinct, the smaller ones being crescentshaped, which divides occasionally into two separate pits; posterior ones confluent and much elongater ; dorsal ones well impressed and in the beak cavity. Pallial line distinct, at which the coruscations end. Nacre uniform and of a brilliant copper tint. Width $2 \frac{1}{2}$ inches, lengtlı $\frac{3}{4}$ inch, diameter $\frac{5}{8}$ inch.

Habitat.-Lakelets of Marion Co., Florida.

Type in National Museum.

Remarks.-Affinity, U. Wultoni B. H. Wright, and $U$. nasutulus Lea. From the former it differs in being smaller, more solid, cylindrical, rarker colored, more prominent umbonal ridge, not subemarginate at hase, and in having a more prolonged dorsal line behiud. Behind, and in size and structure, it reminds one of U. nasutulus, which never has an upturned keel in frout as in our shell, and has a livid nacre.

Whe have great pleasure in naming this species for our good friend and naturalist, Mr. William W. Buxton, of Milo Centre, N. Y., whose company has so often enlivened our collecting excursions. 
Unio Suttoni sp. nov.

Shell oblong, roughened by growth lines and solid, sides dilated almost to the extremities, and slightly constricter near the middle of the base. Base slightly convex or subemarginate, bluntly pointer behind and very abruptly rounded or subtruncate before and slightly arched above. Epidermis reddish or pale olive, with very obscure rays or rayless, slightly wrinkled on the posterior dorsal area or smooth. Beaks depressed and umbos fiattened or slightly rounded. Umbonal ridge obtusely rounded and elevated from beak to base. Cavity of the shell ample and quite uniform; cavity of beaks slight. Nacre heavy, and varying from satin white to dark copper color, and slightly thinner hehind. Cardinal teeth erect, somewhat compressed and bluntly notched. Lateral teeth long and slightly curved, rather slender and compresser. Width $2 \frac{1}{4}$ inches, length $1 \frac{1}{8}$ inches, diameter $\frac{3}{4}$ inch.

Habitat.-Iake near Candler, Marion Co., Florida.

Type and forms in National Museum.

Remarks. - This is an exceedingly variable species like the type of the group to which it belongs, $U$. Buckleyi Lea, It may always be distingurisher from that species by the greater fullness in the posterior portion, and has a slight constriction where that is usually enlarged. It may be distinguished from $U$. Ferrissii Marsh, by its greater and more uniform inflation, straighter base, more obtuse umbonal angle, and is in every way a more massive shell. Fifty specimens have been received from Mr. B. Sutton, of Candler, Marion Co., Florida, for whom we name the species.

\section{ISAAC LEA DEPARTMENT.}

[Conducted in the interest of the Isaae Lea Concbological Chapter of the Agassiz Association by its General secretary, Mrs. M. Burton Williamson.]

After the General Secretary har forwarded the MS. for THE Nautiuus for August, she received a letter from Mr. A. H. Gardner notifying her in re the vol. of 'Transactions. Mr. J. J. White, and Mr. M. Leon $\mathbf{W}$ alker have also reported. At this writing Aug. 10 the vol. is in Mass. 'The Secretary appreciates the notification when the book has been forwaried.

It is not too early to canvass for our next General Secretary. 'The present one would nominate Dr. IV. S. Strode, Lewiston, Ill. for General Secretary for 1898. Dr. Strode has been a valued member for years. 
(Extract from the report of Mrs. D. J. Wentworth. From the Transactions of the Isaac Lea Chapter for isg6.)

No shell is more common on our New England shores than Purpurc lapillus Linné, and yet, no shell of this region has to me, at least, so much of interest connected with it.

Purpuru lapillus is an humble but most worthy descendant of the aristocratic Muricida, and surely the Murex is an aristocrat among shells, with its beautiful forms, dainty sculpturing, delicate coloring, and its long traditions of usefulness and importance.

Plain in its general aspect, as it certainly is, Purpura lapillus has nevertheless, much in common with its more highly favored relations. It is an old member of an ancient race, fossil remains of Purpura lapillus are found in the Red Crag deposits of Europe.

This species is remarkable for its variation in solidity of shell, form, sculpture size, coloring and habitat. It varies in thickness from three-sixteenths of an inch to a shell so thin one could easily perforate the outer lip with a pin. In form they vary from a short broad shell with obtuse spire and flattened whorls to a long shell with acute spire and convex whorls,

In some the coarse revolving ridges are barely discernable, while in others they are very prominent. The faint lines of growth which intersect the revolving ridges of this shell are, in some specinens, brought into marked prominence by rows of ruffles or scallops, and this sculpturing undoubtedly gave Lamarck reason for naming this variety Purpura umbilicata. Many of the solid shells have rows of nodules or teeth within the aperture on the outer lip,

These solid shells are usually grayish-white or white outside, with reddish-purple, yellow or white apertures; but the thinner shells are often brown, orange or lavender, and these colors are frequently banded with white. I have never seen two specimens banded just alike. The orange and white combinations are especially pretty. The variety called by Lamarck $P$. umbilicata, so far as I have observed, are always a greyish-white on the outside, with a reddishpurple aperture. This variety I have found only in a brackish river where they are often seen crawling about in the mud, and their color is so nearly the color of the mud on which they are found that it undoubtedly serves to protect them from the ravages of their enemy. Associated in this river with Purpura lapillus, and much resembling it in size, color and general shape, is the Urosalpin.: cinereu. 'The usual habitat of the Purpura is in the nooks and crevices of rocks. Why do these river shells choose the mud? 
Purpura lapillus is an arctic species and ranges from Norway to New York. It is found on the coast of Europe, where, according to Sowerby, it grows much larger than on our own coast.

This species confines his daily rambles to that part of the shores left bare. by the tides, seldom venturing below low water mark. There on the rocks or other hard substances he finds his favorite food, the succulent barnacle, sometimes varying his diet with a choice bit of Mytilus edulis, to obtain which he will bore through the shell. Finally the mussel becomes so weakened that its valves fly open, when the Purpura promptly accepts the more favorable opening and proceeds to gorge himself with the delicious morsel, after which he will lie inactive waiting for a return of appetite. Limpets, Littorinas. clams, mussels, etc., are said to find a place on his menu.

From time to time throughout the year the Purpura deposits its eggs enclosed in little vase like capsules. These capsules may be found in clusters attached to the undersides of rocks. In confinement it takes about four months for these eggs to mature and then the young do not immediately leave the capsule, seemingly preferring to try their strength a little before venturing on the broad ocean. The young hatched in captivity instinctively leave the water every day, remaining out about the time it takes for the tide to ebb and flow.

A few years ago while fishing I had occasion to crack some Purpura for bait. After cracking their shells I placed the snails in my handkerchief to keep them safely until needed. I soon found that the snails had stained my handkerchief with bright purple spots which repeated washings only served to render more brilliant. Thus I was reminded of the 'Tyrian purple of the ancients, and led to fancy that perhaps in a somewhat similar manner, the dye was discovered. In later years this dye was manufactured in Ireland but so little was obtained from each animal, and other cheaper dyes being discovered, our humble shell-fish were left to die a natural death, and are now useful only to amateur fishermen and so-called "queer people," or "cranks" who go around collecting shells and studying them.

Purpura lapillus commonly called " dog winkle" by the English, has many scientific names, among which are Buccinum lapillus, Tritonium lapillus, etc. But what is a name? The Purpure lapillus under whatever name he has crawled or sailed has a long, interesting honorable history; has during his day and generation been useful and ornamental in the world, doing his duty faithfully according to the light given him and making no pretentions to superiority, and who of us can do better than that? 
28b. Epiphragiophora traski cuyamacensis Hemp. Cuyamaca Mt., San Diego Co.

28c. Epiphragmophora traski tularexsis Pilsbry. Fraser's Mills, 'Tulare Co.

29. Epiphragmopiora carpenteri (Newc.). Coronado Is., and vicinity of San Diego, Cal. Prubably a subsuecies of E. traski. Original locality, "Tulare Valley," perhaps erroneous.

30. Epiphragmophora indonnsis (Yates). Indio, Riverside Co., Cal.

31. Emiphraghophora rowelli (Newc.). Fort Grant, Arizona.

32. Epiphragmopiora arizonexsis Dall. Banks of Santa Cruz River, Tucson, Arizona.

33. Epiphragiopiora magdalenensis (Stearns). Johnson (anyon, near the Panamint Valley, and near Resting Springs, Southern California. Also State of Sonora, Mexico.

34. Epiphragmophora hachitana Dall. Fort Huachuca, Huachuca Mts. and 'Tucson, Arizona; below San Quentin, Lower California ; Peloncello Mts., top of Hachita Grande Mt., Grant Co., near Carrizollilo Springs, New Mexico; and at some adjacent localities south of the international boundary.

35. Epiphragmophora coloradoexsis (Stearns). Grand Canyon of the Colorado River, Arizona, opposite the Kaibab plateau, elevation 3,500 feet; also Inyo and San Diego Cos., Cal.

36. Epiparagmophora arrosa (Gld.). Coast counties from Humboldt to Santa Cruz.

36a. Epiphramophora arrosa f. holderiana Cooper. E. side San Francisco Bay.

36h. Epiphragiophora arrosa f. stiversiana Cooper. Marin Co.

36c. Epipiragmophora arrosa f. marinensis Pils. Marin Co. 36d. Epiphragiophora arrosa expansilabris Pils. Humboldt Co., near Eureka.

37. Epiphragmophora exarata (Pfr.). Santa Cruz Co. to Marin Co., Cal. Probably intergrades completely with the preceding.

38. Epiphragmophora contracostæ Pilsbry. Byron Hot Springs, San Pablo, and Pt. Isabel, Contra Costa Co.; Nachoguero Valley. (Epiphragmophora Arnheimi Dall is the same).

39. Epiphragmophora californiensis (Lea). Monterey, Cal. 39a. Epiphragmophora californiensis nickliniana (Lea). Santa Cruz Co., north (? to Mendocino Co.). 
39b. Eplitiragmophora californiensis anachoreta (W. G. B.).

39c. Epitiragmophora californiexsis ramentosa (GId.). Napa Co. to Santa Clara Co. .

39d. Epiphraguopiora californiensis bridgesi (Newc.). Sin Pablo.

39e. Eipipiragmophora Californingsis diablomsis (J. G. Coop.). San Francisco to Yolo Co.

40. Epiphragmopiora tudiculata (Bimn.). Tulare Co., (typical form).

40a. Epipinagiophora tudiculata cypreopilla (Newc.). Calaveras, Tuolumne, Merced, Tulare and Los Angeles Cos.

40b. Epipinagmophora tudiculata subdolus Hemph. San Jacinto Valley, San Diego Co.

40c. Epipinaghophora tumellata umbilicata Pils. San Luis Obispo Co.

40d. Epipiraghophora tudiculata tularensis Hemph. Fraser's Mills, Tulare Co.

Subgenus Micrarionta Ancey, 1880.

41. Epipinagiopiora gambi (Newc.). San Clemente Island.

41 a. Epiphragiophola gabi facta (Newc.). Santa Barbara and San Nicholas Is.

42. Epipinagmopilora ruficincta (Newe.). Santa Catalina Island.

43. Epiphragiophora intercisa (IV. G. B.). San Clemente and Santa Cruz Is. Forms minor, elegans, nepos and albida Hemph. and callojunctis Pils. have been named.

43a. Epiphragiophora intercisa redimta (IV. G. B.). San Clemente Is. Color varieties castanea and hybrida Hemph. have been named.

44. Epiphragmopiora kelletti (Forbes). Santa Catalina Island. Color forms castanea, nitida, multilineata, frater, californicu, forbesi, bicolor, tricolor, albida Hemph. have been named.

44a. Epiphragmophora kellettil stearnsiana (Gabb.). San Diego, southward, on the mainland.

45. Epiphragmophora tryoni (Newc.). Santa Barbara and San Nicholas Is. Color varieties varius, nebulosa, fasciata, californica and albida Hemphill.

45a. Epipinagiophora tryoni subcarinata Hemphill. Santa Barbara I. ; fossil. 


\section{The Nautilus.}

OCTOBER, 1897.

No. 6.

NEW LAND SHELLS FROM MEXICO AND NEW MEXICO.

BX W. H. DALL.

Holospira (Haplostemma) Cockerelli n. sp.

Shell small, pupiform, blunt-tipped, with two smooth nuclear and about a dozen subsequent whorls; those following the nucleus are rather strongly obliquely ribbed with close set fine riblets which become fainter over the main body of the spire and reappear again on the last whorl; aperture entire, simple, rounded, but a little angular at the posterior nuter corner; the umbilicus closed, the spire gradually enlarging to the eleventh whorl, then slightly attenuated. Alt. $12 \cdot 5$, max. diam. $3 \cdot 2 \mathrm{~mm}$.

Found in the débris of the Rio Grande at Mesilla, New Mexico, by Prof. Cockerell.

This is the second species of Haplostemma, and one of the smallest, if not the smallest, Holospira yet recorded. It forms an addition to the fauna of the United States.

Eucalodium hippocastaneum n. sp.

Shell of moderate size, with 8 (decollate) whorls, the penultimate the largest, thence gently tapering to the decollate apex; surface very dark chestnut brown covered with fine, slightly wavy, close set riblets accompanied by fine axial wrinkles near the sutures, a few irregular spiral threads occasionally appear, suture distinct, umbilicus closed, a faint keel below the periphery of the last whorl, aperture simple, rounded, the peristome slightly thickened, not reflected. Alt. 32 , max. diam. $9 \cdot 2$, aperture $8 \mathrm{~mm}$. 
The species is near E. Boucardii Sallé from Cordova, but differs by smaller size, darker color, less sharp sculpture and the presence of spiral lines.

From San Sebastian, Jalisco, Mex., E. W. Nelson.

Coelocentrum astrophorea n. sp.

Shell pale yellow brown, decollate, with 15 remaining whorls, the first six of which taper, while the rest are subequal; suture distinct wninutely channelled, or with a sharp edged thread on each side of it, surface polished with concavely flexuous small ribs with wider interspaces, on which is visible obscure spiral striation; last whorl keeled below, projecting, aperture rounded triangular, slightly reflected, simple; axis large, pervious except at the base; within the whorl with a medial keel on each side of which it is excavated and vertically ribbed, while from the junction of keel and ribs small spines like the rays of a star project into the lumen of the whorl. Alt. 30, max. diam. 7, aperture $4.7 \mathrm{~mm}$.

From Encarnacion, Hidalgo, Mex., E. W. Nelson.

Though the spines are obviously merely an evolution from the usual nodes, they are remarkable and hitherto unrecorded in any species.

\section{Schazicheila hidalgoana n. sp.}

Shell trochoid depressed with a rather pointed spire and nearly five whorls; white with extremely fine close-set rounded riblets in harmony with the lines of growth; uucleus rounded, smooth; suture very distinct, slope of the spire flattened a little, periphery obscurely keeled; aperture rounded-triangular, outer lip reflected with a shallow sinus at its posterior extremity, rounded below with a thick body callus (on which is a keel for the edge of the operculum) uniting the lips; umbilicus covered by a thin callus, base moderately rounded; operculum (lost)? Alt. 85, mag. diam. 12, min. diam. $9 \cdot 5$, aperture $6 \mathrm{~mm}$.

Found at Encarnacion, Hidalgo, Mex., by Nelson.

This species is obviously distinct from any of those heretofore described in this very limited genus.

\section{ON TWO NEW SPECIES OF AMPHIDROMUS.}

BY C. F. ANCEY.

Amphidromus Fultoni Anc.

Shell sinistral, short, ovate-conic, minutely perforate, thin, obliquely striate, subangulate at the periphery, chiefly at the begin- 
ning of the last whorl. Spire rather briefly conic, apex dark brown; whorls 6 , the first ones distinctly, the last barely, convex; apical whorls white, lower of a pale lemon color; the third ornamented with two faint series of pale brownish and very swall spots; the last with a narrow yellow zone below the suture, circumseribed by an indistinct, broad, white band, and furnished with two fine brown revolving lines more or less evanescent towards the aperture, the upper one at the periphery, the other around the yellow umbilical area. Aperture oblique; columella straight, thin, expanded, white. Lip thin, white, slightly expanded.

Length $23 \frac{1}{2}$, diam. 14, length of aperture $11 \mathrm{mill}$.

Locality: Cochinchina.

This, as well as the following, are members of the group of $A$. flaves Pfeiffer, according to $\mathbf{M r}$. Hugh Fulton, who kindly examined the specimens and declared them to be new species. From the former it differs in being shorter, in having 6 whorls only, a dark colored apex, two narrow revolving bands on the last whorl, and other particulars. Named in honor of Mr. Fulton, who has very thoroughly and carefully monographed this diffieult genus.

\section{Amphidromus Eudeli Ane.}

Shell sinistral, rather solid, oblong-conic, obliquely striate, narrowly rimate; spire conie, apex dark brown; whorls $\overline{7}$, convex, the first ones dull white, the fourth and lower ones cream, with oblique bluish-gray stripes, interrupted at the middle on the penultimate and preceding whorls, and evanescent at the suture; last half whorl bluish-gray, with a cream-yeilow band and umbilical area of the same tinge; a narrow infra-sutural line of a reddish-brown color on the last and penultimate whorls. Aperture small, oblique, expanded, interior grayish. Columella thick, reflected, paler at the upper part. Lip thickened, dark brown externally, purple inside, particularly so near the umbilicus.

Length 28, diam. 14, length of aperture 11 mill.

Locality: near Binh-Dinh, Annam, in forests (E. Eudel).

This is allied to A. zebrinus Pfeiffer, from Siam, but is apparently larger and more solid, and differs in having a purple peristome; externally black-brown, and several striking characters. 
NEW SPECIES OF TERTIARY MOLLUSCA FROM VANCOUVER ISLAND.

BI JOHN C. MERRIAM.

The species here described have already been mentioned by the author as being new forms in a short paper ${ }^{1}$ on the age and general character of two Tertiary faunas from the southern coast of Vancouver Island.

These faunas were referred to two horizons occurring at different localities, one at Carmanah Point at the entrance to the Strait of Fuca, the other near Muir and Coal Creeks in the Sooke district. The horizon at the first-named locality was temporarily designated as the Carmanal Point beds, and is correlated with Conrad's Astoria Miocene, excluding the lower portion of his series which has been supposed to be Eocene. The second horizon was named the Sooke beds, and is, as nearly as can be determined from the study of the known fauna, of Middle Neocene age.

The material on which the descriptions are based was collected by Dr. C. F. Newcombe, of Victoria, B. C., who has kindly permitted the author to study the extensive collections which he has made at both of the above-mentioned localities.

Cytherea Newcombei n. sp.

Shell subquadrate to oval, high, moderately thick, truncated anteriorly. Beaks not prominent. Lunule faintly marked. Surface ornamented with numerous, irregularly placed growth lines and ridges. On some well-preserved specimens a large number of very faint radial lines are visible. Length of large specimen $70 \mathrm{~mm}$., breadth $55 \mathrm{~mm}$. Hinge of right valve with three cardinal teeth and a short pit for the anterior lateral tooth of the opposite valve. This pit for the reception of the anterior lateral tooth is shallower and inuch shorter than in the following species.

Locality: Sooke beds, Vancouver Island.

Cytherea vancouverensis n. sp.

Shell oval, narrowly rounded anteriorly. Beaks prominent. Lunule well marked. The somewhat weathered surface of the shells ornamented by numerous, irregularly placed growth ridges. Length of type specimen 62 ? mm., breadth $48 \mathrm{~mm}$. Hinge of right

${ }^{1}$ Note on Two Tertiary Faunas from the Rocks of the Southern Coast of Vancouver Island. Bull. Geol. Dept. Univ, of Calif., Vol. 2, No. 3. 
valve with three cardinal teeth and a long, deep tooth pit for the reception of the anterior lateral tooth of the left valve. Pit between the two anterior cardinal teetl of right valve ordinarily narrower and deeper than in C. Newcombei.

Locality: Sooke beds, Vancouver Island.

\section{Patella geometrica n. sp.}

Shell large and heavy, up to $50 \mathrm{~mm}$. or more in length, suborbicular. A pex elevated, well forward. Surface ornamented by about twenty broad, strong, radial ribs, which are much wider than the interspaces. Radial ribs crossed by numerous, prominent, narrow, sometimes leafy, transverse ridges.

Locality: Sooke beds, Vancouver Island.

Turritella diversilineata n. sp.

Shell medium size. The imperfect type specimen shows seven flattened whorls, which are strongly bevelled below. Flattened sides ornamented by five revolving ribs of which the lowest, standing on the angle of the whorl, is much stronger than the others. On some of the whorls there are indications of revolving sculpture on the bevelled surface betweel the lowest rib and the suture.

Locality : Carmanah Point, Vancouver Island.

\section{Nassa Newcombei n. sp.}

Shell between 25 and $30 \mathrm{~mm}$. in length. Whorls five, with a well marked shoulder, ornamented by numerous longitudinal and transverse ribs which give the middle portion of the whorls a tesselated appearance. The upper revolving rib, which forms the angle of the shoulder, is stronger than the others and is usually separated from them by a distinct groove. On the last whorl the transverse ribs (about 25) are dominant on the upper portion, excepting the shoulder, and are latticed by the less conspicuous revolving sculpture. On the lower portion of the whorl the transverse ribs disappear, leaving the well-defined revolving ribs uninterrupted.

\section{Bullia buccinoides n. sp.}

Shell ovate, whorls five. Spire short. Suture partially or elltirely covered. Aperture with strong anterior notch. Outer lip thin, sharp; inner lip with broad callus. Length 25-30 mm.

Locality: Sooke beds, Vancouver Island.

University of California, August, 1897. 


\section{EDITORIAL CORRESPONDENCE.}

\section{Marshfield, Oregon (Coos Bay), Aug. 23, 1897.}

My Dear Pilsbry:-Though I have had good success as far as fossits are concerned, it has been the wrong season for land shells in southern Oregon. Everything is three inches deep in impalpable dry dust, and even the trees are dusty. Barring a few Helix fidelis and vancouverensis in aestivation and an occasional Ariolimax, I have seen nothing in the woods, and the rare brooks here are curiously bare of insect or molluscan life.

Since coming to the sea coast I have been too busy to do more than note the commoner species on the beaches, and observe a few items of distribution. The eastern clam, Myn arenaria, has become acclimated, and is one of the best and most abundant bivalves. It was introduced unintentionally with seed oysters from the East. The Pacific oyster, O. lurida, is not now found living in the bay, but specimens (which may have been brought here from other places) occur sparingly in the Indian shell heaps. Unexpected was the presence of Nassa fossuta in numbers, I think not before reported so far north. A rarity of the rocks at Cape Arago is the black abalone, Haliotis cracherodii, of which this must be nearly, if not quite, the northern limit. Among rubbish on the beach were a dead specimen of Mitra maura, and a valve, also dead and worn, of Tivela crassatelloides. These I suspect to be ballast specimens. The beaches offer a poor collecting ground, even Littorinas are scarce. I noted the following species of shells near the entrance of the bay, though winter collecting would doubtless afford a longer list:-

Acmaea patina, pelta, persona and mitra; Olivella biplicata and batica; Purpura crispata, decemeostata and ostrina; Litorina scutulata, Priene oregonensis, Nassa fossatu, Fissuridea aspera, Cryptochiton stelleri, Katherina tunicata and Mopalia muscosa; Mya arenaria, Entodesma saxicola, Cardium unttalli, Saxidomus squalidus, Tresns unttallii, Tapes rigida, Petricola carditoides, Saxicava arctica, Macoma masuta and inconspicna (pink and white varieties), Siliqua patula, Hinnites giganteus; a fragment of Pecten caurinus, and in holes in the sandstones Pholadidea penita, Parapholas californica, Zirphea crispata, Adula stylina and Kellia laperousei.

$$
\text { Yours very truly, }
$$


THE NAUTILUS.

ISAAC LEA DEPARTMENT.

[Conducted in the interest of the Isaac Lea Conchological Chapter of the Agassiz Association by its General Secretary, Mrs. M. Burton Williamson.]

The annual reports will be due in December. Promptness in sending reports will be appreciated by the General Secretary. The annual dues are due in December. The election of President and General Secretary is held in the same month.

Our President, Prof. Josiah Keep, conducted a class in conchology at Pacific Grove this last summer.

COLLECTING AT BALLAST POINT.

(Extract from the report of Mrs. I, T. From the Transactions of the Isaac Lea Chapter for 1896 .)

On Thursday, Dec. 31, 1896, at 8 A. M., our family started out to finish up the year by collecting shells on that day. We went to San Diego-a ten minutes' trip by rail-and then took a naptha launch for somewhere, we were not sure where, until we could take our bearings, and see what places were possible to us.

Out past the ships from England and Australia we made our way, and could soon see the row of little settlements, if such they may be called, along the north end of the bay. Farthest to the east is Roseville, then La Playa, Quarantine, Ballast Point, and farthest to the west, Pt. Loma, a promontory, five hundred feet high, surmounted by its lighthouse.

As we studied our geography lesson, it was decided that our boat should drop us at Quarantine and call for us at 3.30 P. M., at Ballast Point, a distance one and one-lialf miles if you ride, and two miles or more if you walk.

About 10.30 we set our foot on the beach at Quarantine, and, a few minutes later, having eaten our lunch to get it out of the way, we began to work. At high tide the walk we contemplated would have been impossible, as the water comes quite up to the bank, which, much of the way, is a high and precipitous cliff. But the tide was going out rapidly, and not only making a pathray, but uncovering for us what we had come to see. Mr. T., with his Zoology class in mind, walked along at the water's edge, watching closely for all kinds of animal life.

I walked up on the just uncovered beach, seeing what I might capture. My first prize proved to be a "giant key-hole," Lucapina 
crenulata, animal and shell still in partnership. As this was the first one I had seen alive, I was more delighted than if I should have been over the discovery of a continent. I have all the continents I want, but an always ready for another giant key-hole.

Having all paid our respects to our new acquaintance, and recovered somewhat from the shock of finding something we really wanted, we gently put him to rest in the pail of sea water carried by the "zoologist," and we proceeded on our way to other " finds." Not many minutes later another Lucapina met my delighted gaze, and with fewer demonstrations than before, he was seized and sent at once to join his brother.

By this time we had come to the bed of mussels, clams and oysters which had begun to be exposed to view. We had reason to look for rock oysters, Hinnites giganteus, in that section of the country. but as collecting them had never been much in our line before, it took us some time to learn how to find them. They were so muddy and looked so much like other things for which we had no use, that we could'nt always be sure of what we were getting, till afterward. While Mr. T. wrestled with that problem, I amused myself by springing pleasant surprises on cup and saucer limpets, Crucibulum spinosum, and transferring them to my basket trom their happy homes on stones, old shells, broken glass, etc. As this was a new kind of limpet for me to collect alive in any quantity, and of good size, I laid in a good supply. Occasionally specimens of Lutricola alta, Semele decisa, Sanguinolaria Nuttallii, Psammobia rubro-radiata, Bulla nebulosa and Haminea virescens were found along here.

A little further on we began to find quantities of Heterodonax bimaculatus, of a larger size than we had found in San Pedro Bay, of various colors, purple, salmon, white and striped, every one too beautiful to leave!

A few minutes before time for our return boat, our most exciting capture was made, that of a devil fish, presumably 18 inches or more from tip to tip (he would'nt lie still to have his measure taken). He was ruthlessly torn from the hole under a stone where he was domiciled, and, in spite of his writhes and wriggles, was consigned to the sea water pail, which by this time was filled to overflowing with star-fish, sea-cucumbers and the not to be overlooked giant key-holes. Now the star-fish were respectfully invited to take a back seat in some of the numerous bags, etc., which we have learned to carry for just such emergencies, that his majesty, the devil fish, 
might have their room. Aslamed of himself, as he well might be (or was it only a becoming modesty which impelled him?) he immediately began to squirm his way to the very bottom of the pail, and there he remained for the home trip.

Then with heavy loads but light hearts, we found our way to the light house on Ballast Point, where our launch soon called for us. As we went down to the water to step on board, Mr. T., who led the way, saw directly in his path, as if waiting for him, our third Lucapina. Back to San Diego, six miles, we went, and by six o'clock were at home, and preparing to put in formalin "pickle" for future use, the finds of the day.

\section{GENERAL NOTES.}

A few months ago I received from $H$. Rolle, Berlin, two specimens of Achatina crawfordi Melv. One of the shells was broken when received, and noticing that there appeared to be something loose inside, I investigated, and got out three embryonic shells about $8 \mathrm{~mm}$. in diameter. As the Achatinidae are said to be oviparous, this was quite a surprise to me, and I thought a note of it might be of interest to you. As there was no sign of a "calcareous shell," it would appear that this species, at least, is viviparous.

- Geo. H. Clapp.

Polygira mearnsi Dall, has been found by Prof. J. D. Tinsley in the Organ Mts., New Mexico, high up in Filmore Cañon, one dead shell. I am responsible for the identification.

\section{T. D. A. Cockerell.}

Dr. Lorenzo Yates, of Santa Barbara, Cal., has a short article on the shells of Santa Barbara Channel in the August number of the "Overland Monthly."

\section{PUBLICATIONS RECEIVED.}

Messrs Ph. Dautzenberg and H. Fischer have issued their final report on mollusks obtained by the dredgings made by the "Hirondelle" and the "Princesse Alice," 1888-1896. A useful table of the stations precedes the report on species. The operations were nearly all conducted around the Azores Is. New species are de-

I Mém. de la Soc. Zool. de France, X, 1897. 
scribed of the genera Pleurotoma (sensu latissimo), Cerithiella, Amphirissoa (a new Rissoid genus with continuous, reflexed peristome), Basilissopis (a new genus resembling Basilissa, but not pearly, etc.), Eulima, Niso, Turbonilla, Turcicula, Cyclostrema, Cocculina, Puncturella, Acmea, Aliceia (name preoceupied), Isomonia (new group of Anomiide), Chlamys, Amussium, Myrina, Arca, Leda, Malletia, Cardium, Axinus, Diplodonta, Cuspidaria, Verticordia, Thracia and Poromya. All the new forms are figured, but the phototypes are not so clear in detail as we could desire, being decidedly inferior to those illustrating "Les Mollusques Marins du Roussillon," for example. Otherwise the work seems well done in every respect.

In treating the Scalide and the genus Mathilda obtained by the same expedition, ${ }^{2}$ Mr. Dautzenberg has the able assistance of Mr. E. de Boury, well known for his studies on Scalide. Thirteen species are recorded, of which seven are new.

Breeding Sinistral Helices.-Arnold Lang, in Vierteljahrschr. Naturf. Ges. Zürich, XLI, 1896, Jubelband, p. 448, gives the results of two experiments to ascertain whether as a rule sinistral individuals of normally dextral snails produced sinistral or dextral young. The experiments were conducted two consecutive years, once with seven, another time with nine individuals of Helix pomatia. They were completely isolated; and the result was only dextral young. No less than 241 young were obtained from the lot of seven.

Edwin Grant Conklin, Professor of Comparative Embryology in the University of Pennsylvania, has published in the Journal of Morphology for April, 1897, an elaborate work on the Embryology of Crepidula, with especial reference to the "cleavage of the ovum, the formation of the germinal layers and definitive organs, and the axial relations of the ovum to the larval and adult axes." The work is too extensive for abstract here, being, in fact, one of the most thoroughly worked out studies in "cell lineage" yet produced in America, and especially valuable for the attention given to the later stages with the object of tracing the individual blastomeres of the cleaving egg onward to the germ layers. The interesting observations upon the natural history of Crepidula forming part of the prefatory portion of Prof. Conklin's memoir, we hope to reprint later.

2 Same volume. 
Genus CEPOLIS Montfort, 1810.

Section Hemitrochus Swainson, 1840.

46. ('epolis varians (Menke). Key West; Lower and Upper Matacumba Keys; Biscayne Bay. Also New Providence, Inagua, etc., Bahamas.

Genus ACANTHINULA Beck, 1846.

The systematic position of this genus and of Vallonia is unknown.

Section Zoögenites Morse, 1864.

47. Acanthinula harpa (Say). Northern tier of States from Maine to Minnesota; Canada ; Bering Island (Tega); also Sweden, Kamchatka, etc.

Genus VALLONIA Risso, 1826.

48. Vallonia pulchella (Müll.). Montana eastward, from Canada to, or nearly to, the Gulf of Mexico. Europe.

49. Vallonia excentrica Sterki. Quebec and Maine to Maryland, west of Ohio; also Europe.

50. Vallonia costata (Müll.). Quebec to Washington, west to Colorado, Europe.

50a. Vallonia costata montaxa Sterki. Rocky Mits.

51. Tallonia albula Sterki. Quebec, Manitoba, British Columbia.

52. Vallonia Parvula Sterki. Illinois to Nebraska, south to Indian Territory ( $\boldsymbol{V}$. americana Ancey is the same).

53. Vallonia gracilicosta Reinh. Mingusville, Mont.; Fort Berthold, Dakota.

54. Vallonia cyclophorella Ancey. Washington to Montana, south to New Mexico.

55. Vallonia perspectiva Sterki. Northern Alabama and Tennesee to Iowa; Mingusville, Montana.

\section{Subfamily POLYGYRIN虚 (vel Protogona).}

Genus PRATICOLELLA v. Martens, 1892.

56. Praticolella berlaxdieriana (Moricand). 'Texas, Anderson and Bosque Counties southward: also Mexico.

57. Praticolella griseola (Pfr.). Southern-central Texas; also and mainly Mexico, as far south as Vera Cruz. 
Genus POLYGYRA Say, 1818.

(Typical Section).

58. Polygyra cereolus (Mühlf.). Florida Keys and the adjacent mainland.

58a. Polyeyra cereolus carpenteriana (Bld.). Florida, mainly on the west coast.

59. Polygyra septemvolva Say. Central and northeastern Florida.

59a. Polygyra septemvolva sanctijohannis Pils. Valley of the St. John's River.

59b. Polygyra septemyolva yolvoxis (Pfr.). St. Simon's I., Georgia, to Florida and west to New Orleans, La., and Galveston, Texas. (Poly. febigeri Bld. is a synonym).

59c. Polygyra septemyolva floridana Hemphill. Oyster Bay, Florida.

60. Polygyra auriculata Say. Indian River region and St. John's valley to Cedar Keys.

60a. Polygyra auriculata mitroforis Dall. Johnson's Sink, Alachua Co., Fla.

61. Polygyra uvulifera (Shuttl.). Florida, Key West and Cape Sable north to Tampa Bay ; Lake Apopka.

62. Polygyra auriformis (Bld.). Comal, Bexar and Burleson Counties, Texas, east to Uniontown, Ala. and Georgia.

63. Polygyra espiloca ("Rav." Bld.). Sullivan's I., S. C. and St. Simon I., Ga., west to New Orleans, La. and Indianola, Texas.

64. Polygira postelliana (Bld.). Coast counties of Georgia to Baldwin, Florida.

65. Polygyra araka Say. Valley of the St. John's River, Florida.

66. Polygyra pustula (Fér.). South Carolina and Lee Co., Ga., south to St. Augustine and Cedar Keys, Florida.

67. Polygyra pustuloides (Bld.). St. Simon I., Ga., west to eastern Tennessee and Jackson Co., Ala.

68. Polygyra leporina (Gld.). Henry Co., Indiana, through Ky. and Tenn. to Ga. ; Cape Girardeau and Barry Counties, Mo., south and southwest to Ft. Gibson, Ind. Terr., and Anderson, Lee, Washington, and Ft. Bend Counties, Texas. The only typical Polygyra extending north of the Ohio River. 


\section{The Nautilus.}

\section{NEW SPECIES OF MEXICAN LAND SHELLS.}

BY W. H. DALL.

Helix (Lysinoe) Queretaroana n. sp.

Shell large, rugose, with a pale yellow-brown periostracum over a livid whitish, finely granular surface; whorls five, sloping above, with a well marked suture, to a rather elevated narrow apex; below rounded; nuclear whorl and a half smooth, perhaps with microscopic punctuations when unworn; the rest of the surface rugose from irregular iucremental lines and densely covered with minute rounded pustules; apex with a few darker flecks on the whitish ground, but otherwise the shell is destitute of color pattern and entirely without banding; aperture ample, oblique, outer lip simple, not reflected, internally somewhat thickened by a livid rose-colored callus; inner lip rose color, reflected, nearly covering a small perforate umbilicus; throat brownish, deeper just below the suture on the body whorl, a thin callus connecting the somewhat incurved outer lip with the pillar; base turgid, rounded. Alt. 37, max. diam. 39 , min. diam. $32 \mathrm{~mm}$.

Pinal de Amoles, Queretaro, Mexico, E. WV. Nelson.

This fine species is related to $H$. Humboldtiana, from which it is easily distinguished by its color, more pointed spire and less depressed apex. The rose color of the interior becomes less bright witl time.

Helix (Lysinoe) sebastiana n. sp.

Shell large, moderately depressed, of four and a half whorls, with a well marked suture; nepionic whorls two, smooth, plum colored; 
subsequent whorls obliquely flattened above, full and rounded below; surface marked only with incremental lines and irregular minute vermiculations in general harmony therewith; color a dark plum hue, which where covered by the brownish epidermis appears nearly black; at the periphery a narrow white or yellowish band, above it two narrower, nearly equidistant smaller ones, that nearer the suture more or less obscure on the last whorl; the whitish bands are visible inside the aperture, the rest of the shell is dark; aperture ample, produced above, the lip slightly thickened, the pillar broadly reflected over a moderate umbilicus. Alt. 30, max. diam. 40, min. diam. $32 \mathrm{~mm}$.

This species is more depressed than $H$. eximia, and has one less whorl, a darker base and less reflection of the peristome. The granulation is rather sparse and very irregular.

Near San Sebastian, Jalisco, Mexico, Nelson.

Polygyra Nelsoni n. sp.

Shell dark brown, of five and a half rather depressed whorls; suture distinct, surface with well-marked even riblets, separated by wider interspaces, except on the nepionic shell which is smooth, and of two whorls; periphery above the middle of the whorl, base rounded with a deep subcylindrical umbilicus; aperture depressed above, with a wide, reflected, white peristome; basal lip with two well developed teeth and wide callus on the inner edge of the peristome outside of the outer tooth; body with a long sigmoid or nearly $\mathrm{V}$.shaped tooth nearly parallel with the basal lip. Alt. 7·2, maj. diam. $14 \cdot 5$, min. diam. $12 \cdot 0 \mathrm{~mm}$.

With the last. This species differs from $P$. matermontana Pils. (from Colima) by its coarser ribbing, larger size and smaller umbilicus, the peristome is also more oblong. P. plagioglossa Pfr. is smaller with a rounder aperture. A smaller relatively more elevated variety, collisella, alt. 7 , maj. diam. 11, min. diam. $9 \cdot 5$ mm., was found at San Sebastian and La Laguna, Jalisco, by Nelson. The latter is on the Sierra de Guanocatlan.

DESCRIPTION OF A NEW VARIETY OF LAND SHELL FROM IDAHO.

BY HENRY HEMPHILI.

Helix devia variety Clappi IIemphill.

Shell very much depressed; light horn-color; striæ of growth very fine with occasional coarser ones at irregular intervals on some 
of the specimens; epidermis thin, a little brownish in color, and appearing very minutely hirsute in some shades of light under a strong pocket lens; whorls about five, the last flatly convex not descending at its termination, or very little in the largest specimens; spire depressed, very little elevated above the plane of the shell; suture distinct and well defined; aperture transversely lunar, a little flattened beneath; peristome reflected, moderately thickened, with a faint, long lamellar basal deposit on its inner edge, sometimes absent; parietal wall bearing a small white rather sharp-pointed denticle just within the aperture and near the termination of the upper lip, rarely absent; lower surface of the shell flatly convex, with a deep broad umbilicus showing a portion of the penultimate whorl.

Greater diam. of the largest specimen, 15 , lesser $12 \mathrm{~mm}$.

Greater diam. of the smallest specimen, 11, lesser $9 \mathrm{~mm}$.

Height of the largest specimen, $5 \mathrm{~mm}$.

Height of the smallest specimen, $3 \mathrm{~mm}$.

Habitat, Salmon River Mts., Idaho.

This interesting form belongs to a large and very variable, but closely related group of shells that has a wide geographical range, some of its members inhabiting every state and territory of the United States, and even passing beyond its limits. The west coast forms of this group revolve around Helix devius Gld., as a common centre, and radiate from it in every direction, greatly but gradually diminishing in size, increasing, decreasing, diminishing and varying in the number, size and form of the apertural denticles, and with all the imtermediate stages of a broad open, to a closely sealed umbilicus. Our new variety differs from all the other known forms of this group of shells, by the combination of its very depressed spire, basal lamellar deposit, and its large umbilicus. Its nearest ally is variety Blandi, from which it is separated by the basal deposit and larger umbilicus.

I take much pleasure in dedicating this form to my young friend, Mr. Geo. H. Clapp, of Pittsburg, Pa., an intelligent student and enthusiastic collector of American land shells.

\section{NOTES ON SLUGS.}

BY T. D. A. COCKEPELL.

My esteemed friend, Mr. Pilsbry, in conjunction with Mr. Vanatta, has favored us with the first part of a "Revision of North 
American Slugs," which is, in all respects, a most valuable and timely production.

As might be supposed, the authors find it necessary to criticise their predecessors in the study-just as, no doubt, their successors will criticise them. But whatever criticism may be offered, it will always be recognized that they put our slugs on a sounder basis than before, supposing that they finish the work so well begun.

Nevertheless, if they are not careful, they are liable to be troubled by the the shades of the departed; and they have, in fact, woke out of his malacological grave the present writer, who has a few posthumous observations to make herewith.

\section{Ariolimax californicus.}

In Nov., 1889, Mr. H. F. Wickham sent me two examples of this species, which he found at Los Gatos, California. I have before me the drawings I then made of their internal anatomy, which agree with those of Messrs. Pilsbry and Vanatta, except that the epiphallus is less swollen and the retractor penis is not so broad. The epiphallus is clearly shown running to the end of the so-called "flagellum" of the penis; so that this point in the anatomy, which our authors seem to think they were the first to observe, was known to me long ago. Of course they could not be supposed to know anything about an unpublished observation, but had they carefully examined the literature, they would have read Simroth's statement: "Herr Cockerell fand, nach brieflicher Mittheilung, dass ein echtes Flagellum nicht vorhanden ist, sondern dass das vas deferens sich bis su dessen blinden Ende verfolgen lässt." (Malak. Bl., N. F., XI, p. 114). They might also have observed fig. H, pl. V, of W. G. Binney's 3d Suppt., which, though rather rough, is practically correct. Binney himself says the vas deferens "enters the penis at the end of the flagellum below the bulb," (Man. Amer. Land Shells, p. 100), which cannot be considered far wrong. Simroth's figure in Mal. Bl. is, however, unquestionably wrong as to this matter, supposing that he had real californicus before him.

Our authors assume that californicus f. maculatus is really columbianus, on the wholly insufficient grounds that they have never seen spotted californicus. Yet they may be correct, as I never had a spotted californicus I could dissect. My notes on the British Museum specimens are as follows:-

"Ariolimax californicus, from W. G. Binney. Big spot on mantle. 45 mim. long. 
"A riolimax columbiams, from IV. G. Binney, $45 \mathrm{~mm}$. long.

"Really, there is no exterual difference between these shugs!-at least, nothing specific. Californicus is more keeled, and has a narrower sole (sole lat. of cal. 11, of columb. $13 \mathrm{~mm}$.). Sole of columb. is unicolor grayish ochre, that of calif. has lateral tracts grayer ; both are transversely wrinkled. Reticulations on body appear to me to be the same. In color both are ochreous, columb. has black mottling on body (v. maculutus Ckll.) ; calif. has similar black marbling on body, but mantle, instead of being unicolor, has a large black spot, diam. $6 \mathrm{~mm}$., over place of shell (v. maculatus, nov.). This spot on mantle is in fig. of columb. mac. in Binney, Pl. vi, f. A." (Ckll. MSS.).

\section{Ariolimax costricensis.}

Here again our authors must be convicted of hasty judgment. They complain that there is nothing in the description to identify the slug, except the locality ; but they overlook the peculiar olivaceous color. British Museum slugs are not permitted to be dissected, and I gave the best account of the creature I could under the circumstances. It is to californicus much what Parmacella var. olivacea is to $P$. maculata, or Anadenus schlagintweiti to A. altivagus. Whether it is a good species or only a color variety cannot at present be determined, but at least it will be easily recognizable.

\section{Piophysaon.}

In their introductory remarks, our authors allude to the difficulty of identifying West Coast slugs. I believe this difficulty is by no means a serious one, if one is familiar with the literature, and will exclude certain forms which are probably not distinct. The following table may help to separate the recognized species of Prophysaon :-

(1.) Epiphallus stout, sausage-shaped. A pale dorsal stripe.

a. Ochreous species, . . . . . . P. pacificum (incl. flavum).

b. Grayish species, . . . . P. andersoni (incl. hemphilli).

(2). Epiphallus banana-shaped, but tapering at the end. No pale dorsal stripe, . . P. ccernleum (Epiphallus rather slender, flattish, tapering, somewhat curved. Shell $2 \mathrm{~mm}$. long, narrow, white, shiny).

(3). Epiphallus slender, gradually tapering to a point. Body with a blackish dorsal band. 
a. Jaw ribbed, . . . . . . . . P. fasciatum.

b. Jaw only striate, . . P. humile. (Until more material of humile is seen, it cann ot be made sure that the jaw-character is a specific one.)

My present opinion is that Phenacarion must bo merged in Prophysaon s. str.

In order to further elucidate some of the forms of Prophysaon, I give below some of my notes, made years ago, but not published at the time.

Prophysaon hemphilli IV.G. Binney (as Phenacarion).

This nust not be confounded with $P$. hemphilli B. and B., which I consider specifically identical with andersoni. I know little more about it than may be gathered from Mr. Binney's account. Mr. Binney sent me one from near the mouth of the Chehalis River, and I noted at the time: looks like type foliolatus in alcohol. Sole pale yellowish white. Edge of foot dark, with darker transverse lines. Body bluish-gray, tapering; mantle more brownish.

\section{Prophysaon foliolatum (Arion foliolatus GId.).}

Comparing this with $P$. hemphilli B. \& B., I noted:- Sole white, oblique transverse grooves visible. Transverse dark streaks on edge of sole more strongly marked, alternating strong and weak Body exactly the same color (in alcohol) as hemphilli B.\& B. Pale dorsal line very slightly indicated. Reticulations practically as in hemphilli, but foliations more distinct. Mantle not so dark and brownish-tinged; bands represented by subcoalesced black marks; black spots scattered about. As I wrote in An. Mag. N. Hist., 1890, "it is most difficult to separate P. foliolatum and Proph. hemphilli (i. e. andersoni) specifically." An alcoholic example of hemphilli differed from foliolatum as under-

\section{Prophysaon hemphilli B. \& B.}

Sole slightly yellowish, only wrinkled transversely. Marks on edge of sole quite similar, but not so well marked. Body purplish mouse-color, i. e., gray with a lilac tinge. Mantle dark, with indistinct "smoke colored band." Body tapering. No mucus pore. A pale dorsal line is barely indicated just behind mantle to half length of back. Slug $42 \mathrm{~mm}$. long. 


\section{Prophysaon andersoni (Cooper).}

An alcoholic from Olympia was described thus:-Twenty four $\mathrm{mm}$. long. Sole yellowish-white. Oblique grooves as in foliolatus. Markings on edge of sole as in hemphilli B.\& B., but not so dark. Body same color as hemphilli, but paler at sides; in fact, white above sole at sides. Reticulations as in hemphilli, showing out lilac-gray on the whitish sides. Pale (rather brownish) dorsal line. No indication of any keel. Body much less tapering than in hemphilli. No mucus pore. Mantle smaller and more rounded at ends than in hemphilli, decidedly brownish, its edges pale. There are indistinct subdorsal bands on mantle. Ovotestis imbedded in liver; in fasciatum it is visible without moving liver.

A living $P$. andersoni from Haywards, California, sent by Dr. Cooper, agreed with the above, but differed in its mantle, which was not brown but grayish, heavily marbled with dark gray dorsally, so as to appear almost uniform blackish, and at sides with dark gray or blackish marbling showing out plain on the pale ground. The surface of the mantle is beautifully beaded-granular. 'The pale dorsal line is brownish tinged, thus differing from the rest of the body.

The epiphallus of P. andersoni v. suffusa, from Chehalis, Wash., is very stout, shorter than that of typical andersoni.

\section{Prophysaon humile.}

A Cour d'Alene example, compared with fasciatum, differs thus:Sole gray instead of yellowish. Transverse wrinkles not oblique. Grooves on edge not dark. Reticulation practically the same. Dorsal band on body much reduced. Ground color grayish.

\section{Prophysaon fasciatum.}

Specimens in alcohol were sometimes tinged with scarlet, but I could not be sure whether this was natural or due to some accidental staining.

In conclusion, I hope it will not be supposed that all the characters above given are believed by the writer to be specific. The purpose is, simply to point out differences between the specimens which have been differently named, without deciding how far those differences are specific. In my Check-List of Slugs, and elsewhere, I have indicated my opinion about the species as such.

Mesilla, New Mexico, Sept. 15, 1896. 
ISAAC LEA DEPARTMENT.

[Conducted in the interest of the Isaac Lea Conchological Chapter of the Agassiz Association by its General Secretary, Mrs. M. Burton Williamson.]

For the benefit of our new members I will say that while the Popular Science Nens is the official organ of the Agassiz Association, The Nautilus is the official organ of our Conchological Chapter.

Please bear in mind the annual reports and dues are to be sent in next month. This department is made up from the reports of our members. Let us make this year's volume of 'Transactions the best we have ever had.

The volume when last heard from had just been forwarded by Mr. Hilles Smith to Mr. James H. Lemon, Toronto, Ontario. 'The book has "gone the rounds" rather slowly this year.

COLLECTING DURING THE SUMMER OF '96.

[Extract from the report of Mr. H. Howe. From the Transactions of the Isaac Lea Chapter for I896].

During the summer months I collected around San Pedro and Long Beech. A very pretty and rather rare shell is the Acteon punctocelatus Cpr., commonly called the "barrel shell." It may be found alive during June, July and August, at the roots of the eel-grass where it comes to breed. 'The eggs are almost microscopic and are laid in coiled masses about one inch in length, which is twice the size of the entire Mollusk shell and all. The Actoon (also called Rictaxis) lives in deep water and can only be collected during the breeding season.

In August I made a trip to Anaheim Landing in company with a friend, also a collector. As the low tide occured at four o'clock in the morning (and we live about ten miles away) we had to start at two o'clock in the morning. On arriving at our collecting ground we set to work and soon had excavated several fine Glycimeris generose and Schizotherus Nuttalli. These are about the hardest shells to collect that I know of, for they live from two to three feet down in the mud. In the soft clay we dug out some fine Pholas pacifica and Zirphaea crispata, Bulla nebulosa and Pecten cequisulcatus, were very large and plentiful. At this place I found my first live Nussa perpinguis. When hunting for the burrows of 
the Glycimeris, unless an expert, one is apt at the end of his search, to be very much disgusted at finding instead of the desired mollusks, nothing but a "sea cucumber."

At San Pedro I secured a dozen or more living specimens of Chrysodomus Kellettii, brought in from deep water by a fisherman, and, collected on the mud-flats a few Trophon Belcheri and a large Mactra Hemphillii.

In the pholas bed at San Pedro I found some large specimens of Adula stylina and Lithoplagus plumula, three young Parapholas Californica and a few specimens of Nettastomella Darwinii, a little borer about three-fourths of an inch long and gaping widely at the posterior end.

After a heavy tide at Long Beach one may collect occasional specimens of Periploma planiuscula Sby., Clidiophora punctata and odd valves of Raeta undulate and Yoldia Cooperi.

While on a camping trip this summer to Maliban Ranch, a rocky strip of sea coast about twenty miles north of Santa Monica, I collected my first specimens of Lasea rubra. It is a tiny bivalve about the size of a pin-head, and the smallest Pelecypod on this coast. I found them on the byssus of Mytilus Californicus. On the same rocks with, and feeding on the Mytilus I found a fine series of Purpura saxicola the largest and most beautiful I have seen. In color they varied from white and orange to jet black, some striped, some plain, others smooth, and still often slightly roughened. I think this is about the only place in Los Angeles County where Purpuras are to be found. (Two or three collectors have found Purpuras at Portuguese Bend, in Los Angeles County. Purpura saxicola and Purpura lima var. emarginata, are synonymous terms used for one of our Californica purpuras. The shell figured in "West Coast Shells" as $P$. lima refers to another shell.-M. B. W.).

\section{NOTES AND NEWS.}

In $L^{\prime}$ Echange for June, 1897, p. 46, Mr. Locard establishes a new genus Assiminopsis for the new A. abysorum, from the Atlantic south of Portugal in 1,205 metres depth. It is probably Rissoid.

M. Jules Mabille's "Observations sur le genre Bulla" in Bull. Soc. Philomathique de Paris, 1895-96 (published in 1897), is prac- 
tically a monograph of the group, although there are numerous omissions. B. ampulla is split into several species formerly (and justly) regarded as varieties. B. vernicosa Gould is described as new under the name "B. secunda." $B$. adamsi Mke., which has already had several synonyms, figures as "B. subaustralis sp. nov." B. dubiosa, habitat unknown, and $B$. delorti, Japan, are also described as new. The first is certainly well named. In all 23 species are mentioned, this number including several not entitled to that rank. In the monograph published in Manual of Conchology, 1894 , there are 32 , not counting "bad" species.

In his "Contributions a la Connaissance des Mollusques Terrestres et d'Eau Douce de Kaméroun," Mr. Adolf d'Ailly has made a substantial addition to the rather meagre literature of west African land shells. The shells described were collected by three Swedish naturalists, Mr. P. Duzén and Drs. Y. Sjöstedt and J. R. Jungner* The Cameroon fauna is rich in species of Ennea, 17 being enumerated, 8 of them new. The Zonitoid genera Helicarion, Zonitarion, Thapsia and Trochozonites are represented by numerous species with many new forms. In the Achatinide a new genus, Ganomidos, is proposed for Achatina Shuttlevorthi Pfr. and A. Barriana Sowb. The genus Petitia Jousseaume (of tautologic fame) is recognized for Achatina pulchella Martens, of which Petitia Petitia Jouss. and Ach. Smithi Sowb. are reckoned synonyms. Pseudachatina, Perideris and Limicolaria are well represented. M. d'Ailly has independently arrived at the conclusion that the sculpture of the embryonic shell is frequently a character of high value in the Pulnonate snails. Five well-drawn lithographic plates illustrate the new species described.

Valionia parvula and Pupa Holzingeri.-In the October Naurilus just received to-day I notice that Vallonia parvula Sterki, is not given as occurring east of Illinois. In the summer of 1891 I discovered this species on Put-in Bay Island, Lake Erie. The specimens were submitted to Dr. Sterki, and determined by him. Associated with it was Pupa Holzingeri Sterki, which is also a Mississippi Valley form. The occurrence of these two species so far east may be of interest to you.-Briant WALKER.

${ }^{1}$ In Bihang till K. Svenska Vet.-Akad. Iandl. Bd. 22. 
Polygyra plicata Say. Kentucky, Tennessee and the adjacent parts of Georgia and Alabama. Helix hazardi Bld. is synonymous. The name plicata was not preoccupied in Polygyra, to which genus Say originally referred this species.

Polygyra dorfeuilliaxa Lea. Washington to Cooke Counties, Texas, through Indian Territory, Ark., La. to the Coosa River, Ala., north to Arkansas City, Kansas, Benton County, Mo., and Kentucky opposite Cincinnati.

Polygyra dorfeuildiana sampsoni Wetherby. Texas, Indian Terr., Mo., Ark.

Polygyra fastigiata Say. Henry Co., Ky. to Montgomery and Franklin Counties, Tenn. Helix fastigans Lucy Say in Bld., is a synonym.

Polygyra Jacksoni (Bld.). Indian Territory, Ark., and Mo. north to Canden Co.

Polygrea Jacksoni deltoidea Simpson. Fort Gibson, Indian Territory.

Polygyra troostiana Lea. Tennessee, Kentucky. ***** * *

Polygyra oppilata (Moric). Cedar Keys (Bimey). A southern Mexican and Yucatain species, the occurrence of which in Florida requires confirmation.

Polygyra mooreand (W. G. Bimey). Central and southern Texas.

Polygyra mooreana tholus (W.G. B.). Washington County, Texas.

Polygyra bicruris (Pfr.). Brownsville and mouth of Rio Grande River, Texas. A Mexican species.

Polygyra vextrosula (Pfr.). A species of northwestern Mexico, reported from Texas by Binney.

Polygyra ventrosula hindsi (Pfr.). Texas, according to Binney.

Polygyra materiontana Pils. 'Texas; also Sierra Madre, Mexico.

Polygyra texasiana (Moric.). Indian Territory and throughout Texas.

Polygya trionontoides (Bld.). Barry Co., Mo., Indian Territory, southwestern Louisiana, south to Corpus Christi, Texas.

Polygyra latispira Pils. Western Texas.

Polygyra ariadre (Pfr.). Texas, on the Rio Grande, according to Biuney. 
Polygya hippocrepis (Pfr.). Near New Braunfels, Comal Co., Texas.

Polygyra levettei (Bld.). New Mexico, Santa Fé Canyon, near Santa Fé; Arizona, near Tucson; Fort Huachuca, Huachuca Mts.

Polygya levetter thomsoniana Ancey (var. orobona Anc. is probably not distinct).

Polygyra chiricahuana Dall. Arizona near Tucson, Fly Park, Chiricahıa Mts., Cochise Co., at 10,000 ft. alt.; New Mexico, Jemez Mts. near Bland, and at Jemez Sulphur Spring, 8-10,000 ft. above the sea.

Polygrra Asmuni Dall. Bland, New Mexico.

Polygyra pseudononta Dall. White Oaks, New Mexico.

Polygyra rhyssa Dall. White Mountains of New Mexico.

Polygyra uearesir Dall. Huachuca Mts., Arizona, and Hachita Grande Mt., Grant Co., New Mexico, at 8,000 to 9,400 ft. altitude. Also Filmore Canyon, Organ Mits.

\section{Section Triodopsis Rafinesque.}

Polygira tridentata (Say). Canada to Michigan, south to northern Alabama.

Polygyra tridentata juxtidexs Pils. Southern New York to North Carolina and West Virginia.

Polygyra tridfintata edentilabris Pils. Cumberland Mts.

Polygyra tridentata conflanata Pils. Burnside, Ky.

Polygyra fraudulenta Pils. (Helix fallux of authors, not Say). Ontario, Canada, to Michigan and Illinois, south to Georgia.

Polycira fallax (Say). (Helix introferens Bld.). Eastern Pennsylvania and New Jersey from Philadelphia southward to Fanning Co., Ga.; Holston Valley, Tenn.; IV. Va.

Polygyra fallax obsoleta Pils. Newbern, N. C.

Polygyra hopetonensis (Shuttl.). Newbern, N. C. to Georgia Sea Is. and Mayport, Fla., west to Cedar Keys, Fla.

Polygyra vannostrandi (Bld.). Aiken, S. C.; Augusta, Ga.; Jacksonville, Fla.

Polygyra vultuosa (Gld.). Eastern Texas and Indian Terr., north to Pettis Co., Mo.

Polygira, vultuosa inenrietr.e (Mazyck). Angelina, Lee and Robertson Counties, Texas.

Polygyka vultuosa copei IVeth. Hardin Co., eastern Texas, Calcasieu Parish, La.

Polygyra vultuosa cragini (Call). Neosha and Bourbon Counties, Kansas; Eureka Springs, Ark.; Wood Co., Texas. 


\section{The Nautilus.}

V01. XI.

DECEMBER, 1897.

No. 8.

NEW WEST AMERICAN SHELLS.

BY W. H. DALL.

Sigaretus 0ldroydii Dall, n. sp.

Shell large, thin, naticoid, with a short spire and 3-4 inflated whorls; color pale brown, livid on the spire, fading to waxen on the base; surface sculptured with extremely fine wavy spiral striæ; aperture ample, oblique, the outer lip thin, a little patulous, the -borly covered with a thin callus, the pillar lip obliquely cut away, wide near the junction with the body, the basal part of the margin receding; umbilicus large, pervious, its walls covered with a thin, silky, brown wrinkled epidermis. Alt. 35 , diam. $37 \mathrm{~mm}$.

A single specimen in deep water off Catalina Id., Cala., collected by Mr. and Mrs. T. S. Oldroyd.

This species is easily distinguished from any other recorded, by its very thin shell, naticoid form and wide pervious umbilicus.

Pecten Palmeri Lall, n. sp.

Shell thin, orlicular, compressed, equilateral, white to yellowishbrown, with concentric or zig-zag narrow bands or flecks of dark rose color; 15 strong ribs rounded in the young, mesially keeled and longitudinally threaded in the adult, separated by narrower channelled interspaces, each with a mesial threal; all crossed by lamellose, concentric, ratlıer sparsely distributed elevated lines; submargins and ears closely radially threaded with imbricated threads. Both valves similarly sculptured; alt. 47.5, lat. 53, diameter about $20 \mathrm{inm}$. 
A number of valves collected near the head of the Gulf of Cala. by Dr. E. Palmer some years ago.

Pecten Randolphi Dall, n. sp.

Shell small, thin, glassy, unsculptured, except by minute "camptonectes" striation which covers both valves, and more or less obscure concentric undulations which are most distinct on the right valve near the umbo, and in some specimens altogether absent; hinge straight and short, anterior ears distinct, posterior ears not defined by any fold or sinus, outline suborbicular, valves compressed, especially the right one; right anterior ear with six small imbricated radii above, below a wide, transversely striated fasciole derived from a well marked byssal sinus; ctenolium with four or five functional spines. Alt. $27 \cdot 5$, lat. 26 , diam. $5 \mathrm{~mm}$.

Off Destruction Island, State of Washington, in 516 fathoms, bottom temperature, $35^{\circ}$ Fahr., U.S. Fish Commission.

This species was obtained at a number of stations, from Bering Sea to West Mexico, in 225 to 1005 fathoms. It is named in honor of Mr. P. B. Randolph, of Seattle, who has done excellent work on the Puget Sound fauna.

Pecten Davidsoni Dall, n. sp.

Shell small, suborbicular, compressed, waxen white, the left valve with 21 rounded ribs, surmounted by (when not worn off) continuous rows of minute subglobular scales, the interspaces wider, flat and perfectly smooth, ear's very small, the anterior with five or six imbricated radii; sculpture obsolete near the umbones; right valve sculptured with faint concentric impressed lines over the whole surface, and distally with numerous minute, obsolete, fine, scaly riblets; posterior ear transversely striated, very small, anterior one with four or five scaly radii, a well marked sinus leaving an imbricated fasciole and no ctenolium. Interior polished, the left valve fluted internally in harmony with the external ribs. Alt. 14, lat. 14, diam. $3.5 \mathrm{~mm}$.

On the Davidson Bank, Alaska, in 280 fathoms, green mud, and north of Unalaslık, in Bering Sea, in 351 fathoms, sand; U.S. Fish Commission.

This little shell resembles somewhat $P$. (Propeamusium) alaskensis Dall, externally, but wants the radiating lire internally, is smaller, and lias faint radiating sculpture on the right valve, which is wanting in P.alaskersis. 
NOTE ON TWO SPECIES OF HELICINA.

BY C. F. ANCEY.

1. Helicina Rabei Pils., recently described in the NautiLus from specimens collected by Dr. Rabe, must be the sante as the previously described $H$. rufocallosa Anc., based on the examples long ago distributed by Dr. J. D. E. Schmeltz, of the Museum Godeffroy, under the erroneous name of H. Fischeriana Montr. (which may be identical with "H. Picheriana" of Paetel's Catalogue). The species is from Peleliu, Pelew Islands, and the color is very variable. 'The type specimen is grayish with a red basal callosity, but I have, since I published $H$. rufocallos $\alpha$, procured other specimens having different shades of coloring.

2. Helicina Funcli Pfeiffer, originally described from New Granada (Funck), is also found at Greytown, Nicaragua. It has also been detected on Monkey Hill, near Colon, Isthmus of Panama, by Mr. Aillaud. The size of the two specimens collected in the latter spot is different, one of them being considerably smaller and tinged with pink-red on the last whorl.

\section{OXYCHONA UNMASKED.}

BY H. A. PILSBRY.

Those who have interested themselves in South American land shells will recall the group Oxychona of Mörch, containing a few acutely keeled, trochus-shaped Brazilian species, the best known of which is Helix bifasciata Burrow.

In Costa Rica and southern and eastern Mexico there are some similar Helices which had been placed in Geotrochus, Corasia, etc., but which the present writer in $1889^{2}$ transferred to Oxychona. This disposition also commended itself to von Martens, who in $1893,{ }^{2}$ adopts the same view. In my " Guide to the Study of Helices," 1894, no doubt was expressed regarding the alliance of the

1 The true Fischeriana is a larger shell, allied to mifocallosa (= Rabei) and is probably confined to the islands near eastern New Guinea.

${ }^{2}$ Man. Conch. (2), v, p. 128.

- Biol. Centr. Americana, Moll., p. 152. 
Brazilian and Mexican species, and by the kinduess of Professor Gwatkin, of Cambridge, England, who supplied a mounted preparation, I was enabled to figure the jaw and teeth of Helix bifasciata, the type of Oxychona, and up to this time, the only species of the group to be dissected. At that time I called attention to the resemblance in dentition between Oxychona, Papuina, Polymita and other arboreal Helices, ending with an allusion to the teeth of Otostomus (now known as Drymcens amrisleporis). Recently whilé studying the aurisleporis group of Bulimi, I was again struck with the extreme resemblance of their radulie to that of Oxychona. Now; since my former examination of Oxychona, the study of Bulimulid groups has been revolutionized by the discovery of extremely characteristic generic and subgeneric characters in the sculpture of the nepionic shell, as the part formed within the egg is called; so that I at once examined the apex of the Orychona. The lens revealed in H. bifasciata and the other Brazilian species, the minutely "grated" senlpture of Drymceus! This combination of the very characteristic and peculiar nepionic sculpture of Drymaus ${ }^{4}$ with the equally characteristic dentition, conclusively show that Oxychona is a Drymceus masquerading as a Helix. The Central American and Mexican species referred to Oxychona have smooth apices, very different fronı the Brazilian group. There can be little doubt that these are true Helicide; and as they must now be cut adrift from Oxychona, I propose to reinstate for their reception the group name Leptarionta Crosse \& Fischer, based upon Helix bicincta Pfr. This will stand as a genus, and may still be left in my group Belogona euadenia (dart bearers with true glands), next to Lysinoe, until more is known of the soft parts. At least one of the species, L. trigonostoma, is known to have a serrate keel on the tail like Lysinoe.

Figures of the apices of Oxychona and its Bulimulid allies may be found in the current volume of the Manual of Conchology. The evidence supplied by Semper, Hedley and myself that true Helices often appear disguised as Bulimi, now finds its counterpart in the Bulimulide, in such Helicoid species as Bulimulus eremothauma Pils., and that worst cheat of all, Drymous (Oxychona) bifasciatns Burrow.

${ }^{4}$ Drymius includes not only the Aurisleporis group and the flaring lipped Bulimuli like serperastus, but also "Bulimulus" dormani and multilineatus among Floridian species, either of which, if unworn, will show the apical sculpture alluded to under a sufficiently strong lens. See NaUtiLus, IX p. 114. 
ISAAC LEA DEPARTMENT.

[Conducted in the interest of the Isaac Lea Conchological Chapter of the Agassiz Association by its General Secretary, Mrs. M. Burton Williamson.]

A number of good reports have been promised. The volume of Transactions has been forwarded by Mrs. Mary P. Olney to Mrs. Drake, who will forward it to Mrs. King at Napa, Cala. By that time all our members will have received it.

In the November Nautilus Mr. Herbert Lowe's name appeared as "Howe" in the article on "Collecting During the Summer of '96."

The following nominations have been made for the officers of the Chapter for 1898: for President, Prof. Josiah Keep; for General Secretary, Dr. Wm. S. Strode.

Dr. William Healey Dall has named a new shell collected in Alaskan waters Crenella Leunu, in homor of Dr. Isaac Lea, for whom our Chapter was named. The shell, a little bivalve, is described in a Bulletin issued by the Natural History Society of British Columbia, entitied "Notice of Some New or Interesting Species of Shells from British Columbia and the Adjacent Region," by William Healey Dall, Hon. Curator Dept. of Mollusks, U. S. National Museum. The Bulletin contains 18 pages, 2 plates, with 38 figures, and an index to all species mentioned in the text. Of the 30 species figured in this pamphlet, 27 are Dr. Dall's species, 23 are new species and 4 have been described by him but not figured in The Nautilus. Leda taphria Dall, known on the West Coast as L. celata Hinds (non Conrad) is figured.-The October Nautilus for 1896, contains a note on this species.-The genus Malletia is for " the first time recorded from the northwest coast of America."

MORNING TIDES.

[From the report of Mrs. M. L. Beck. From the Transactions of the Isaac Cliapter for 18961 .

One bright day in June I was told we were to go collecting the next day at San Pedro, and as the tide would be low at half past three in the morning, we would have to go to the beach the evening before and stay all night at the cabin on the island. * * $\mathrm{We}$ ate supper, and while two of us got things ready for the night, the 
rest went out on the breakwater to admire the scene. The high tide by moonlight was exquisitely beautiful.

At three o'clock, after having breakfasted, we started out to collect while the moon was still shining brightly on the water. The tide was so low it seemed to me we could have walked over to San Pedro. Mrs. O. and I lingered back of the other collectors, and soon she picked up a Ranella californica IIds., a fine specimen which now has a corner in my cabinet. How I did wish I could fiud one. I poked around with my trowel and suddenly I struck a lump; picking it up, it proved to be a perfect specimen of Pleurotoma carpenteriana Gabb, four and a quarter inclres long. As I was afterward told, the only live one found in the bay. After returning to the cabin we put it in water, and when disturbed it exuded a purple fluid.

We walked to Dead Man's Island and found a number of Actceon punctoccelatus Cpr. in the pools, Marginella Jewettii Cpr., Plasianella compta Gld. clinging to the sea grass on the rocks; plenty of Fissurella volcano, Chlorostoma anreotinctum and Littorina planaxis all along the breakwater. On our way back to the cabin we collected Haminea virescens Sby., Bulla nebulosa Gld., Conus californicus Hds. and Nassa tegula Rve. We also brought home a good many Chione, from which we made delicious soup.

In July we went to Alamitos Bay, five miles from Long Beach; it was another fine low tide. 'This time seven of us went in a wagon at four o'clock in the morning. We found Crucibulum spinosum Sby. on oyster shells, Ceritlidia californica and Melampus olivaceus crawling up the grass stalks near the edge of the water, Edalia subdiaphana, Angulus variegatus, Liocardium substriatum and Donax flexuosus living as it seemed in harmony together, also Amiantis callosa Conr., Tapes staminea Conr., Olivella batica Cpr., and many other shells.

\section{NOTES AND NEWS.}

Molluscan Fauna of Freshivater Iakes in Central Cenebes.-Herrn P. and F. Sarasin direct attention to the remarkable molluses which live in the large and deep inland lakes of Celebes. The forms they were able to capture point to the existence of a fauna perlaps as interesting as that of the Lake of Baikal. 
The authors begin with the new Gasteropod Miratesta celebensis, for the reception of which it seems necessary to establish not only a new genus, but a new family (Miratestidæ). The structure, which is briefly described, shows a combination of characters distinctive of various families. The animal is nearest the fresh water Pulmonates, especially the Limneidæe, as is suggested by the Planorbis-like structure of the radula, the nervous system without chiastoneury, the liermaphroditism, and the absence of an operculum. But any very close affinity is impossible, as is shown by the large gills, the very peculiar pouched feelers, and the structure of the shell. Dis. tant relations may, perhaps, be found in the so-called Thalassophile (Amphibola and Siphonaria). In any case, the family is phylogenetically old, near the base of the freshwater Pulmonates.

Bulletin 142 U. S. Geol. Survey, 1896, contains a valuahle paper upon the geology and paleontology of northwestern Louisiana by T. Wayland Vaughan. A number of new mollusks from Lower Claiborne and Jackson stages of the Eocene are described and figured.

Mr. Charles Schuchert has given a very useful "Synopsis of American Fussil Brachiopoda, including Bibliography and Synonymy" in Bull. No. 87, U. S. Geol. Survey, 1897. The geological distribution, terminology, biological development and classification are discussed, and a valuable chapter contributed by Prof. Charles E. Beecher treats of the morphology of the brachia, a subject which in Beecher's hands has assumed great importance as an index of phylogeny and rank.

Mr. Félix Bernard has given a very thorough account of the anatomy of Chlamydoconcha Orcutti Dall, in Annales Sciences Naturelles (zool.), iv, 1896, pp. 221-252, with 2 plates.

\section{A NEW PLICATE UNIO.}

BX BERLIN H. WRIGHT.

Unio Walkeri sp. nov.

Shell solid, ovate, inflated at the umbos, rough, plicate-nodulose on posterior slope and indistinctly so anterior to the umbonal ridge; gradually fading out near the centre of the disk. Umbonal ridge uniformly rounded below and sharply angulate above. Epidermis nearly black; transmitted light showing a light-colored texture. Very faintly marked anterior to the umbonal angle with broad, widely separated, interrupted rays. Posterior margin bluntly rounded or somewhat disposed to biangulation, uniformly rounded before, dorsum arcuate, base nearly straight or emarginate, cavity uniform, moderate and scarcely extending under the dorsal plate. Teeth solid, single in the right and double in the left valve. Anterior cicatrices barely distinct. Thinner behind, showing the plica- 
tions through. Nacre livid or bright pink. Width 2 in. length 1 in. diam. $\frac{5}{8}$ in.

Habitat: Suwannee River, Madison Co., Florida.

Remarks: A large series of this peculiar shell shows considerable variation in strength of, and area covered by the plications, sharpness of the umbonal ridge and color of nacre. It cannot, however, be mistaken for any other species. Its natural place is between Unio subtentus Say and Unio penicillutus Lea. We name it in honor of our esteemed conchologist Mr. Bryant Walker of Detroit, Mich.

POLYGYRA FERRISSI n. sp.

BY H. A. PILSBRY.

Shell resembling Polygyra dentifera Binn. in size and general form. Imperforate, thin, glossy, last two whorls of a very bright chestnut color, becoming light green on the earlier whorls. Spire very low, convex. Whorls $4 \frac{2}{3}$, all rather convex, the first minutely rugose, granulate, following whorls of the spire slowly widening arcuately striate and sparsely granulate, the granules oblong, generally upon the striæ; last whorls rapidly widening, a trifte constricted behind the peristome, very little descending in front, sculptured with fine, rather low strixe of growth and very fine, subobsolete close spiral impressed lines; base very little inpressed at the center. Sutures well impressed throughout. Aperture oblique, wide-erescentic; peristome white, shading through pink to a broad purple band at the margin, very broad and flatly reflexed, appressed over and closing the umbilicus; parietal wall with a transparent film between the lips, and bearing a small oblique tooth nearer to the termination of the outer than to that of the basal lip.

Alt. 13, greatest diam. 21.5 , least $18 \mathrm{~mm}$.

Alt. 11, greatest diam. 20, least $16.5 \mathrm{~mm}$.

Klingman's Dome and Mirey Ridge, Great Smoky Mountains (between Tenn. and N. C.).

Mr. Jas. H. Ferris found this very beautiful Helix during his summer journey in the Great Smoky range this year, with the banded form of Polygyra Andrewse, a very dark, unicolored form of the same, $P$. Clarkii of extraordinary size, and other interesting snails.

P. Ferrissi is intermediate between several very distinct Helices. It has the convex green and granulate inner whorls of $P$. subpalliata Pils., the fragile substance and flat, wide lip of $P$. dentifera Binn., and the sculpture of the last whorl somewhat like $P$. appressa perigrapta Pils.

The combination of these characters, together with the deep, rich reddish chestnut color of the body-whorl, emphatically negative a reference of the specimens to any of these species. The half-grown shell, $14 \mathrm{~mm}$. diam., has an umbilicus $1 \mathrm{~mm}$. wide and is very obsoletely angular at the periphery. 
96. Polygira rugeli (Shuttl.). Wythe Co., Va., south to Columbus, Ga., and west to Clinton, Ark.

97. Polygyra inflecta (Say). Pennsylvania west of the Allegheny Mts., west to Illinois, south to Sea Islands of Georgia, Alabama, Mississippi and Indian Territory.

98. Polygyra euentata (Sampson). Boston Mts., Washington and Crawford Counties, Arkansas (Triodopsis edentula IV. G. Binney is the same).

99. Polygrra devia (Gld.). Vancouver Is. and Puget Sound region south to $46^{\circ} \mathrm{N}$. Lat.

99a. Polygyra devia hemphilli (IV. G. B.). Kingston and Old Mission, Idaho; Spokane, Wash. (synonyms are Helix binominata 'Tryon, $H$. mullani var. olneyae Pilsbry).

99b. Polygyra devia mullani (Bld. \& Coop.). Near Coeur d'Alêne Mission, Coeur d'Alêne Mts., Idaho; west side of Bitter Root Mts., IVash.

99c. Polygira devia ilarfordiana (W. G. B.). Salmon River, Idaho (H. salmonensis Tryon and H. commutanda Ancey are synonyms).

99d. Polygyra devia Clappi (Hemph.). Salmon River, Idaho.

99e. Polygra devia blandi (Hemph.). Salmon River, and Post Falls, Idaho.

99f. Polygyra devia oregonensis (Hemph.). Eastern Oregon.

100. Polygyra sanburin (W. G. B.). Kingston and Old Mission, Idaho.

101. Polygyra columbiana (Lea). Sitka to Santa Cruz, Cal. 101a. Polygyra columbiana labiosa (Gld.). Coeur d'Alêne Mts., Idaho; Deer Lodge Valley, Montana.

102. Polygyra armigera (Ancey). San Francisco, Cal., to Vernon, B. C.

103. Polygyra roperi Pilsbry. Redding, Shasta Co., California.

104. Polygyra loricata (Gld.). Eldorado to Fresno Co. west to Sonoma Co.

$$
\text { * * * * }
$$

105. Polygyra profunda (Say). Western New York to Minnesota and Wyandotte Co., Kansas, south to Lee Co., Va., and Vicksburg, Miss. ; not east of the Allegheny Mits. in Pennsylvania and Maryland. 
106. Polygyra sayil (Binn.) Quebec, Ont., northern Maine and Mich., south to Great Smoky Mits., N.C.

106a. Polygira sayil chilitoweensis (Lewis). Mountains of east Tennessee and western North Carolina.

107. Polygyra kiowaensis (Simpson). Kiowa Station, Limestone Gap and near Eufaula, Indian Territory.

107a. Polygyra kiowannsis arkansaensis Pils, near Hot Springs, Ark.

108. Polygy ra townsendina (Iea). Del Norte Co., Cal., to Seattle, Wash.

108a. Polygyra townsendiana ptychophora (Brown). Deer Lodge, Montana, west through northern Idaho to Spokane, Wash., and in northern Oregon west to the Dalles. There is a color form, castanea Hemph.

$$
\text { * } \quad * \quad *
$$

109. Polygyra albola bris (Say). Canada to Kansas, Arkansas and Georgia. The form dentata Walker occurs in Michigan, etc.

109a. Polygyra albolabris alleni Wetherby. Arkansas.

109b. Polygyra albolabris maritima Pils. New Jersey shore. Var. traversensis Leach $\mathrm{ms}$. from Michigan is scarcely distinguishable.

109c. Polygyra albolabris major (Binn.) Northern Alabama and eastern Tennessee to North Carolina and Macon, Ga.

110. Polygyra exoleta (Binn.). Western New York and Pennsylvania to Illinois and Missouri, south to Virginia, Georgia and Alabama.

111. Polygyra multilineata (Say). Western New York to Minnesota and Iowa; Wyandotte, Ks.

112. Polygyra divesta (Gld.). Vernon Co., Miss., to Indian Terr.; Louisiana, Arkansas and Barry, Jasper and Dade Counties, Mo.

113. Polygyra roemeri (Pfr.). Central Texas, Fort Worth to Bexar Co.

114. Polygyra wetherby (Bld.) Whitly and Pulaski Co., Ky., and Roane County, Tenn.

115. Polygyra dentifera (Binn.). Province of Quebec, Canada, southwest to Swaim Co., N.C.

116. Polygyra Ferrissi Pilsbry. Mirey Ridge and Klingman's Dome, Great Smoky Mts. 
117. Polygyra subpalliata Pils. Roan Mt. region to Cranberry, N. C.

118. Polygyra paliatata (Say). Ontario to Michigan, south to Georgia and Luuisiana.

119. Polygyra obstricta (Say). Ohio and Indiana south to northwestern Georgia and Batesville, Ark.

119a. Polygyra obstricta Carolinensis (Lea). South Carolina; northern Alabama, and adjacent parts of Tennessee and Georgia.

119b. Polygyra sargentiana (Johnson \& Pilsbry). Neal Woodville, Alabama. Helix sargenti J. \& P., not Bld., is a synonym.

119c. Polygyra appressa (Say). Western Pennsylvania and Scott Co., Virginia, west through Ohio, Indiana, Illinois and Missouri, south to Arkansas and Kentucky.

119d. Polygyra appressa perigrapta Pils. Tennessee and adjacent parts of bounding States N., E. and S.

$$
\text { * * * }
$$

120. Polygyra elevata (Say). Western New York to Wisconsin, south to northwestern Georgia and Missouri; Wyandotte, Kansas. The form with a brown band has been called $f$. cincta Taylor. Chattanooga and Knoxville, Tennessee.

121. Polygyra clarkir (Lea). Cherokee and Clay Counties, N. C., E. Tennessee, N. W. Georgia.

122. Polygyra pennsylvanica (Green). Western Pennsylvania to Illinois, S. to Monroe Co., Virginia, and Tennessee.

123. Polygyra andrewse (IV. G. Binn.). Roan and Great Smoky Mts., Tenn., Habersham Co. N.-E. Ga., and Bibb Co., Central Ga.

124. Polygyra thyroides (Say). Canada to Minnesota, south to St. Simons I., Ga., and Texas.

124a. Polygyra thyroides pulchella Ckll. Toronto, Canada.

124b. Polygyra thyroides bucculenta (Gld.). Louisiana and Texas. Hardly recognizable as a variety.

125. Polygrra clausa (Say). Western Pennsylvania to Minnesota, south to Wyandotte, Kansas, Jackson Co., Ala., and Sea Islands of Georgia.

126. Polygyra wheatleyi (Bld.). Mountains of western N. C.; Habersham Co., Ga. 
127. Polygyra christy (Bld.). Mountains of Cherokee, Swain and Rutherford Counties, N. C.

128. Polygyra mitchelliana (Lea). Western Pennsylvania, Ohio and Kentucky, Monroe Co., Va., and Cherokee Co., N. C.

129. Polygyra downieana (Bld.). IVhitley Co., Ky.; eastern half of Tennessee.

130. Por.ygrra lawe (Lewis). Hayesville, Clay Co., N. C. ; Monroe Co., Tenn.; Houston, Hall and Habersham Counties, Ga.

130a, Polygira lawe tallulanensis Pils. Tallulah Falls, Georgia.

131. Polygyra mobiliana (Lea). Mississippi to Baldwin, Florida, along the Gulf.

132. Polygyra jejuna (Say). Savannah, Ga., S. to Indian River and No Name Key; west to Pensacula, Florida.

\section{Section Stenotrema Rafinesque.}

133. Polygyra spinosa (Lea). Eastern Tennessee, N. Alabama, and northwest Georgia.

134. Polygylua labrosa (Bld.). Northern Alabama, Arkansas, southern Missouri.

135. Polygya edgariana (Lea). Mountains of 'Tennessee and Alabama.

136. Polygyra EDwardsi (Bld.). Fayette or Greenbrier County, W. Va., Laurel, Whitley and Pulaski Connties, Ky.

137. Polygyra barbigera (Redf.). Habersham and Hall Counties, Ga.; Cherokee Co., N. C., also Alabama.

138. Polygyra stenotrema (Fér.). Henry Co., Ill. to Virginia, south to Georgia, southwest to Indian Territory.

138a. Polygyra stenotrema subglobosa Pils. Woodville, Alabama.

138b. Polygyra stenotrema depilata Pils. Thunderhead Mt. ; near Nashville, Bellevue and Johnson City, Tenn.

139. Polygyra hirsuta (Say). Canada to Minnesota, south to Wyandotte, Kansas, and Jackson Co., Ala. (also reported from near Guaymas, northwestern Mexico).

139a. Polygyra hirsuta altispira Pils. Magnetic City, Roan Mountain, and Black Mountains, N. C.

140. Polygyra maxillata (Gld.). Mountains of Tennessee, Alabama and Georgia (near Columbus).

141. Ponygyra monodon (Rack). Canada to Minnesota, south to North Carolina and San Antonio, Texas.

(To be continued.) 


\section{The Nautilus.}

Vol. XI.

JANUARY, 1898.

No. 9.

SOME NEW EOCENE FOSSILS FROM ALABAMA.

BY T. H. ALDRICH.

Anomia navicelloides n, sl'.

Shell thin, pearly, with lines of growth on the outer surface of the superior valve, very nacreous and shining within, the upper valve having a distinct beak, not marginal. Surface bearing traces of broad radial color bands; interior showing three cicatrices, the larger one with semicircular lines and fine striations crossing them.

Breadth of superior valve $13 \mathrm{~mm}$., width $23 \mathrm{~mm}$.

Locality.-Near Choctaw Comer, Ala., Wood's Bluff horizon. Has very much the appearance of a Navicella, which has suggested the name. Only the upper valve so far discovered.

odontostomia matthewsensis n. sp.

Shell small, medium thickness, smooth, whorl six, spire rather blunt, suture impressed; aperture rather narrow, with one strong fold on the columella, also partly reflected and rather pointed at base.

Length $3 \frac{1}{2} \mathrm{~mm}$., width $1 \mathrm{~mm}$.

Locality.-Matthews Landing, Alabama.

Cancellaria annosa n. sp.

Shell small, spire obtuse, whorls four, shouldered, strongly cancellated, nodular at junction of lines, the revolving line below the suture more strongly nodular than the others; outer lip expanded, nodular within; columella with two folds.

Height $2 \frac{1}{2} \mathrm{~mm}$., breadth $1 \frac{1}{2} \mathrm{~mm}$. 
Locality.-Matthews Landing, Alabama Rv.. Alabama. While the type specimen is a young shell, yet the characters are very distinct from any other species known.

Cancellaria graciloides n. sp.

Shell broadly fusiform, spire elevated, whorls 6-7, rounded, slightly shouldered, cancellated, first three smooth, on the others the revolving lines are numerous, strongly defined; lines of growth smaller and much finer than the revolving lines, suture deeply impressed, outer lip expanded, strongly nodular within, columella with three folds, aperture pointed and canaliculate at base.

Height $12 \mathrm{~mm}$., width $7 \mathrm{~mm}$.

Locality.-Gregg's Landing, Alabama Rv., Alabama.

Cancellaria graciloides var. bella n. var.

Characterized by strong, rounded varices, as many as three on the body whorl. Shell is smaller than the type.

Height $10 \mathrm{~mm}$., width $6 \mathrm{~mm}$.

Locality.--Gregg's Landing, Alabama Rv., Ala.

\section{A PROPOSED CENSUS OF MICHIGAN MOLLUSCA.}

BY BRYANT WALKFR.

At the Anmual Meeting of the Michigan Academy of Science in December, 1895, a suggestion was made that the conchologists of the State should form a "Section of Conchology" for the purpose of united work in that department.

A circular of inquiry elicited such favorable responses, that in the spring of the following year a temporary organization was effected with a membership of fourteen as noticed in the NAutulus for April, 1896. At the present time the membership includes every active collector in the State so far as known. Practical work being the object of the Section, it was decided, as a preliminary step to the complete knowledge of the fumna of the State, to undertake the compilation of all the known localities for every species known, or supposed to belong to it. A form of blank was prepared for distribution upon which the individual reports should be made, and another upon which these reports should be tabulated. A special map of the State has also been printed showing the principal river and lake systems upon which it is proposed to spread these tabulated 
results, and thus form a permanent record, which should show at a glance all that was known of the distribution of every species belonging to the State. These maps it was believed would be of value in studying the various questions which might arise in regard to the present distribution of the fauna and the means by which it lias been brought about. Up to the present time there have been filed twelve reports, which include all the private collections of the State and nearly all the public museums. The collection of the University of Michigan is now heing worked over and arranged by Mr. $\mathrm{H}$. E. Sargent, and the report from the Kent Scientific Institute of Grand Rapids is expected during the coming winter. As soon as these are received, the Section will be in possession of all existing data to be obtained from State sources in regard to the extent and distribution of the molluscan fauna.

These reports aggregate more than 4,500 entries, and include nearly every species that has ever been quoted from Michigan.

It is proposed also that every member of the Section shall annually file a supplemental report containing such additional information as he can supply. In this way it is expected that the records of the Section will be continually kept up to date, and at all times afford the collectors of the State and others interested in the subject, not only a correct statement of what is actually known of the State fauna, but also indicate in what sections of the State field work should be done and what species require further investigation.

The value of this work has already been demonstrated by a series of charts which have recently been completed showing the distribution of the Unionidce. Some of the results deduced from them were quite unexpected, and are believed to be of great value in determining the manner in which geological and geographical factors have influellced the present range of many of the species. This will be made the subject of a special report to the Academy at its Annual Meeting.

It has been suggested that there are undoubtedly in the cabinets of many of the readers of the NAUTILUS interesting material from Michigan, a record of which would be a valuable addition to the data now in the possession of the Section. In all probability a large amount of collecting has been done in the State at one time or another by those who were not residents, and whose collections are not represented in any of the reports thus far received. It is very desirable that every possible source of information should be made 
available for the work in progress, and the members of the Section will be very grateful for any assistance they may receive from their brethren of other States.

In behalf of the Section of Conchology, I would theretore earnestly request that all collectors, who have any Michigan shells in their collections, would furnish a list of the species and localities, which may be filed for permanent record. Blanks will be gladly furnished for that purpose to any one who will address the writer at 18 Moffat Building, Detroit, Michigan.

\section{ON A NEW SPECIES OF VITREA FROM MARYLAND.}

BY WM. H. DALL.

The land shell fauna of the north-eastern U. S. has been so thoroughly searched, and by so many collectors, that we do not expect the addition to it of good and valid new species, unless among the minuter forms like Vallonia. However, as if to prove that hope may spring eternal in the conchological breast, a new species with undoubtedly distinct characteristics has come to hand from Maryland.

Vitrea Raderi n. sp.

Shell depressed, four-whorled, smooth except for faint rather regularly spaced incremental lines above, of a pale waxen whitish color; spire hardly raised above the last whorl, which is much the largest; periphery evenly rounded, suture appressed, base moderately rounded, the umbilical slope of the last whorl somewhat flattish; umbilicus very wide, exhibiting all the volutions; aperture wider than high, the upper margin slightly in advance of the lower lip, the two connected by a thin wash of callus over the body. Alt. $1 \cdot 5$, max. diam. $4 \cdot 0$, min. diam. $3 \cdot 0 \mathrm{~mm}$.

Received from Prof. Howard Shriver, as collected at Cumberland, Md., in the summer of 18.97 ; a single specimen.

The nearest relative of this species is Zonites wheatleyi Bland, which is a larger shell with higher spire, more rounded whorls and a much smaller and more steep sided umbilicus. It may be mentioned that the figure of Vitrea wheatleyi in Binney, Bull. 28, U. S. Nat. Mus., is inaccurate in representing the umbilicus as wider than it really is in that species. The large form of $Z$. wheatleyi referred 
to by Binney (p. 222) as collected by Hemphill at Clingman's Peak, North Carolina, is doubtfully identical with Bland's type, and should take the varietal name of $V$. clingmani, which may eventually prove of specific rank.

The present species is named in honor of Mr. Rader, an interested student of the land shells of Cumberland, at the request of Prof. Shriver. The type is in the National Museum.

\section{A NEW UNDULATE UNIO FROM ALABAMA.}

\section{BY BERIIN H. WRIGHT.}

\section{Unio triumphans sp. nor.}

Shell sub-triangular, with an elevated wing which is connate at its point, coarsely and interruptedly undulate over the entire disk, except on the extreme anterior and superior parts where pustulations and literations replace them. Disk gradually and uniformly flattened out to the margins from the highest point near its centre: the indistinct umbonal ridge dividing the disk area into two nearly equal parts. Substance of the shell moderately thick; thicker before. Epidermis dead black. Greatest diameter in the center of the shell. Dorsal notch very long and deep. Cavity of the beaks deep. Posterior cicatrices confluent; anterior ones distinct. Lateral teeth short and distant from the cardinals which are depressed. Nacre dull white in front and a bright coppery tinge behind, and very iridescent. Width 4 inches, length 5 inches, diameter 2 inches.

Habitat, Coosa River, St. Clair Co., Alabama.

Type in National Museum.

Remarks: For several years we have had old specimens of this sheil and could not place them satisfactorily with any known form. In a recent collection of one thousand shells from this vicinity we found twenty specimens of all ages which at once made its novelty appparent.

The natural place we assign the species is between $U$. boykinianus Lea and $U$. multiplicatus Lea, and it atso possesses characters of $U$. undulatus Barnes. Compared with the first, our shell is more winged and therefore more triangular in outline; the ridges are fewer, not so prominent and more broken, like Unio undulatus 
Barnes, and the umbonal ridge is not as well defined; the laterals are shorter and the shell is more transverse; the undulations cross the umbonal elevation instear of running parallel with it and the beaks are less prominent. Compared with $U$. multiplicatus Lea our shell is subtriangular in outline instead of trapezoidal, always more winged and shorter, and the laterals are also shorter; the posterior slope is more gradual and the umbones are not flattened, and are more depressed than in that species, the highest point being nearly in the centre of the disk where there is quite a prominence; the cardinals are more depressed and the pustulations extend more generally over the anterior portion.

In old specimens the sculpture diminishes almost to smoothness except in the superior parts, the umbonai elevation becomes obsolete and the slrell is more elongated. Twenty specimens of all ages have been compared with specimens of corresponding ages of all the allied species, and comparisons with the type forms in the National Museum have been made through the kindness of Mr. Charles T. Simpson.

MODIOLA PLICATULA LAMARCK-AN EXTINCT LOCALITY.

BY R. E. C. S.

Fifty years ago, more or less, that part of the city of Boston which includes the Public Garden and the grand array of fine avenues and streets that reach out east and west, north and south, and form what is locally known as the Back-Bay Section, was a portion of a larger territory, some six hundred acres, of wet and dry marsh and mud flats, that extended from Charles Street at the foot of "Boston Common," to Roxbury. A considerable portion of this region was inhabited by a peacefully disposed and quiet community. In numbers this community, certainly if counted, would have made a bigger showing than the census of human bipeds that constituted the population of Boston at that time. Though numerous, they were not influential and had no social status among the best people of "Modern Athens."

This may have been owing to the fact that their ancestors did not come over in the Mayflower, or later with Winthrop and Saltonstall. No, they were here, or their forefathers were, long before the advent of the "Pilgrim Fathers;" they had an older claim, prior- 
ity of settlement and occupancy, than any white man. Their title was aboriginal, and they were and had been, from time immemorial, permanent residents "to the manner born." Whether their lack of social position was due to the fact that they did not recognize the merits of "baked beans and brown bread," "cod-fish balls" and "pumpkin pie," etc., as gastronomic delicacies, or were unable to sing "penny royal hymus" through their noses-having no noses to sing through-can only be surmised, as they were not given to gossip or backbiting, but always maintained a discreet and dignified silence. While they were the only permanent residents, they often had transient visitors. Various salt-water birds frequented the region at certain times in the year. Yellow-legs, doe birds, curlew, teal duck and other species were pretty certain to make a short visit whenever a "northeaster" was brewing.

The locality now known as Copley Square, with its impressive buildings, Trinity Chureh, the Art Museum and the new "Old South," was good hunting ground in those days. Most people, including many credulous or unsophisticated Bostonians, honestly regard these church edifices as erected for religious purposes, and think, too, that the "Museum of Fine Arts," of which they are rery proud, is intended to foster and encourage the work of painters and sculptors. No one will deny such persons the right of opinion, even if it does rest upon a halluciuation; on the other hand a fellow may be pardoned who sees in these "places of worship" simply funeral monuments sacred to the memory of the thousands of harmless mollusks, Modiola plicatula, that were buried alive in a so-called Christian city in the nineteenth century, with bo one to say a word in their behalf. And the Art Building! What of that? It may be regarded as commemorative of the fact that the spot whereon it stands was good hunting ground in days long since gone by, and that hereabout my father (of blessed memory) and myself oftentimes successfully pursued ornithology for gastronomic purposes.

In course of time, it is highly probable, suitable tablets will be placed in front of the principal buildings bearing the following inscription :-

"The region hereabout was formerly inhabited by a branch of the great aboriginal family ModroLA. The members of the local tribe, Plicatula, were peaceful in their lives, simple in their habits, never told lies, never talked back to old people, and met. their fate without a murmur.

"Keep their memory green." 


\section{ISAAC LEA DEPARTMENT.}

[Conducted in the interest of the Isaac Lea Conchological Chapter of the Agassiz Association by its General Secretary, Mrs. M. Burton Williamson.]

As the annual election of officers for 1898 is not held until the last Wednesday in December, the results of the election will not be published this month. Next month the newly-elected General Secretary will have charge of this department.

\section{RECORD OF A LOST YEAR.}

[Extract from the report of Mrs. M. T. B. From the Transactions of the Isaac Lea Chapter for 1896$]$.

This year I have found no shells new to my collection, but have learned more about some of the old ones. Conus californicus, which I found at Newport, Cal., last year in the mud bottom of the bay, I find among the rocks, clinging to the sea weeds. These last are bright and shining, while those from the bay have an epidermis. A learned friend, to whom I refer all my difficulties, thinks the epidermis is worn off by the action of the water and rocks. But I found them in a deep cut in the rocks, where the high tide covered and the low tide left them-a very sheltered place. We are not credited with two species on our California coast, yet I find two which differ in color and size-one is brown, mottled with lighter spots, the other is plain, paler in color, and reaches double the size of the spotted one. The operculum of Conus is the merest excuse, just a thread, and not half the length of the aperture.

Under the same rocks I found Leptothyra, with rough, limy surface, but with such exquisite opercorli, shelly white, with a spiral line in brown. And then there were the pretty little Corbula luteola and Carditamera subquadrata, the last place I should have looked for bivalves.

I have become interested somewhat in sea-slugs, and have tried to make water-color drawings of some of them, as I know of no way to preserve them without destroying their color.

Two rare shells have come under my observation during the year, both from Newport, and both were Trophons. Pecten hastatus, which is called a northern species, is occasionally found here also, and, though I have seen but few of the northern shells, those I have seen are not nearly so brilliant as those from Newport Beach. 
141a. Polygyra monodon fraterna (Say). Penngylvania to Texas.

141b. Polygya nonodon aliciæ Pils. Calcasieu Parish, S.IV. Louisiana.

141c. Polyg Yra monodon cincta Lewis. Hayesville, N. C.

142. Polygyra rear (Ward). Ohio and Michigan to Minnesota, south to Nashville, Tennessee, and Neosho Co., Kansas.

143. Polygyra germana (Gld.). Astoria, Oregon, to Tancouver Island.

Genus POLYGYRELLA Binney, 1863.

144. Polygyela polygyelat (Bld. \& Coop.). Coeur d'Alêne Mts., Idaho. A variety montanensis Ancey is described from Deer Lodge Valley, Montana.

145. Polygyrella harfordiana (Coop.). Fresno Co., California, in the "Big Tree" District, 6500 feet above the sea.

Subgenus Ammonitella Cooper, 1869.

146. Polygyrella yatesi (Coop.). Calaveras Co., California, at Murphy's and Cave City.

Subfamily Sagdinæ (vel Teleophallogona). ${ }^{1}$

(ienus THYSANOPHORA strebel \& Pfeffer, 1880.

147. Timsanophora incrustata (Poey). Corpus Christi, Galveston and Hidalgo, Texas. Also Cuba.

148. Thysaxolitora hornil (Gabb). Fort Grant, Arizona; summit of Hachita Grande Mt., Grant Co., New Mexico; also Yaqui River, Mexico.

149. Tirsanophora rortex (Pfr.). Marco, near Cape Sable, and Key West, Florida. Also Bermuda and West Indies.

150. Tirsanophora ingersolli (Bld.). Colorado, at high altitudes: San Juan, Custer and Mesa Counties; Fly Park, Arizona.

150a. Thysanophora ingersolli convexior (Ancey). Logan Canyon, Utah; Weston, eastern Oregon.

151. Thysanophora Plagioptrcha granum (Streb.). Archer, Alachua Co., Evans' plantation, Rogers River, and vicinity of Lake Worth, Florida. Also eastern Mexico and Iucatan, and typical plagioptycha from Porto Rico.

${ }^{1}$ This subfamily should have preceded the Polygyrinx. 
THE NAUTILUS.

152. Thysaxophora dioscoricola CACA (Guppy). Lake Worth to St. Augustine in eastern, and near Hillsborough River in western Florida; Hidalgo, Texas. Also Trinidad, and typical dioscoricola from Jamaica.

Family BULIMULID涩.

Genus BULIMULUS Leach, 1815.

Subgenus Orthotomium Crosse \& Fischer.

153. Bulimulus dealbatus (Say). Southeru North Carolina, west to Kentucky, Central Missouri and Kansas; south to Alabanla and the Rio Grande.

153a. Bulimulus dealbatus ragsdalei Pils. Texas: Cook and Montague Co. on the Red River, and at Comstock, etc., on the Rio Grande.

153b. Bulimulus deamatus mooreanus (Pfr.). Texas; mainly from Fort Worth to De Witt and Uvalde Counties. [This is the shell generally known as "B. schiedeamus" in American collections].

153c. Bulmulus dealbatus schiedeanus (Pfr.). Western Texas; mainly Mexican, Texas specimens being still rare in collections.

154. Bulimulus alternatus maria (Alb.). Texas: two or three tiers of counties north of the Rio Grande, from Corpus Christi to Frio and Valverde Counties. The typical alternatus has not yet been found north of the Rio Grande.

Genus DRYM EUS Albers, 1850.

155. Drymaus serperastrum (Say). A Mexican species, said to occur also north of the Rio Grande in 'Texas.

156. Dryuleus dormani (IV', G. Binn.). St. Johns River Valley and east coast; also West Florida, south to Caloosahatchee River.

156a. Drymaus dormani albida Wright. Eastern Fla.

157. Drymeus marielinus (Poey). S. Florida; Upper Matacumba Key, N. to Micco on the east coast.

158. Drymaus Floridanus (Pfr.). Florida.

159. Drymeus hemphilli (Wright). East Florida, between Mosquito Lagoon and the Atlantic; Lake Helen, Volusia Co. 
Section Mesembrinus Albers.

160. Drym eus yultilineatus (Say). Key West, Bahia Honda Key and Lower Matacumba Key, and north to Marco on the west coast of Florida; also Venezuela.

\section{Genus ORTHALICUS Beck, 1537.}

161. Orthalicus undatus (Brug.). Key West to the neighborhood of Bay Biscayne, Florida; also W'est Indies, Jamaica, etc.

162. Orthalicus melanocheilus floridexsis Pils. Florida, near Cape Sable; Pavilion Key.

Genus LIGUUS Montfort, 1810.

163. Liguus Fasciatus (Müller). Southern Florida; Key West, Lignum Vitæ and Grassy Keys, to Key Biscayne; on the Gulf Coast from Cape Sable to Goodland Point, near Marco. There are numerous color varieties.

\section{Family UROCOPTID君 Pilsbry.}

Genu: UROCOPTIS Beck, 1837 .

Section Cochlodinella Pils. \& Tan., 1898.

164. Urocoptis poeyana (Orb.). Key West and adjacent keys; Miami Country, Florida.

165. Urocoptis JeJura (Gld.). Near mouth of Miami River, Florida.

Genu: MACROCERAMUS Guilding, 1828.

Section Microcerumus Pils. \& Van., 1898.

166. Macroceramus pontificus (Gld.). Key West to Key Biscayne, and northward to Tampa, Florida.

167. Macroceranes Floridanus Pilsbry. Sarasota Bay and Goodland Pt., Florida (= M. Gossei of authors part, not of Pfr.).

168. Macroceramus texanus Pilsbry. New Braunfels, Texas (= M. gossei auct. part, not of Pfr.).

Genus HoLospira Von Martens, 1860.

Section Holospira s. s.

169. Holospira goldfussi (Mke.). Texas, on the Blanco and at New Braunfels, Comal Co. 


\section{Section Haplostemma Dall.}

170. Holospira mearisi Dall. Top of Hachita Grande Mt., Grant Co., New Mexico.

171. Holospira inamiltoni Dall. Rio Grande Mts., Brewster Co., Texas, $3,500 \mathrm{ft}$. elevation.

172. Holospira cockereldi Dall. Débris of Rio Grande River at Mesilla, New Mexico.

\section{Section Eudistemma Dall.}

173. Holospira arizonensis Stearns. Dos Cabezas, Arizona.

Section Distomospira Dall.

174. Holospira Bilamellata Dall. Hachita Grande Mt., New Mexico.

\section{Subgenus Metastoma Strebel \& Pfeffer.}

175. Holospira roemeri (Pfr.). New Braunfels, Comal Co., Texas.

176. Holospira crossei Dall. Top of Hachita Grande Mt., Graut Co., New Mexico.

177. Holospira pasonis Dall. Mule Canyon, El Paso Co, Texas, $4,000 \mathrm{ft}$. alt.

178. Holospira pilsbryi Dall. Arizona or New Mexico, exact locality unknown. State of Puebla, Mexico.

\section{Genus CERION (Bolt.) Morch, 1952.}

179. Cerion incanum (Binn.). Florida Keys and mainland at Cape Florida. (A specimen of the Cuban C. mumiola has been found at Tortugas, but probably it was accidentally imported in some manner. No indigenous land shells are known from the Tortugas.)

\section{Family PUPID床.}

Genu: STROBILOPS Pilsbry, 1892.

(=Strobila Morse, 1864, not of Sars, 1835, Acalepha, nor of Sod., 1837, Lepidoptera, nor Strobilus Anton, 1839, Mollusca).

180. Strobilops labyrinthica (Say). Most of the eastern U. S., southwest to Texas.

180a. Strrobilops labyrinthica strebeli (Pfr.). Jackson Co., Ala.; Northern Flurida; Eastern Mexico. 


\section{The Nautilus.}

VOL. XI.

FEBRUARY, 1898.

No. 10.

UNIO (LAMPSILIS) AMPHICHENUS, N. Sp.

BY LORRAINE S. FRIERSON.

Shell large, oblong oval, thin, slightly inflated, gaping for onehalf its length at the anterior and basal part, and at the upper part of the posterior end, and covered with a shining, black or brownish epidermis which is decidedly wrinkled in places; growth lines strong and irregular; beaks but slightly prominent; hinge line evenly curved; hinge teeth but feebly developed, there being a single, compressed, rather sharp cardinal in the left valve of the young shell which becomes blurred and shows a tendency to split up in the older shells, and two rather short, faint laterals, the inner of which is the stronger ; these being placed at the extreme posterior end of the hinge plate, with one cardinal, and sometimes a faint one above it, and a single, compressed, short lateral in the right valve; laterals ending abruptly at the posterior end, with the inner edges slightly curved upwards; area between the teeth narrow and rounded; muscle scars distinct, and quite deep for so thin a shell; posterior retractor scar completely united with the adductor, dorsal scars to the number of five or six extending in a row from the cavity of the beaks just behind their greatest projection towards the anterior base; pallial line showing a tendency to break up into several lines, and distinct traces of a posterior sinus; nacre clouded, varying from deep violet to bluish and white.

Leigth 106, height 63, diam. $36 \mathrm{~mm}$.

Habitat, Sabine River at Logansport, Louisiana. 
This is one of the most distinct and remarkable Unios in the United States. In its general structure, the hinge characters, the row of dorsal cicatrices, the incipient pallial sinus, and the gaping shell it shows relationship with Unio tenuissimus, and its nacre is something like that of this species, but the female shell is considerably swollen in the post-basal region, and it reminds one a little of a short, compressed, female Unio rectus. The posterior opening, however, is its most remarkable character, commencing about midway up the end of the shell, and extending nearly to the ends of the laterals. This gap ends abruptly above, and less so below; the edges of the shell are reflected outwards, and considerably lamellated, and in old shells the remains of former reflected apertures may be seen. The opening in a fully adult shell is about one-fourth of an inch wide and one and one-fourth inch in length, and is as distinct as that of Schizothorus muttalli of the west coast of the United States, and occupies about the same relative position that it does in this marine bivalve. It may possibly group with Unio tenuissimus, but it is quite likely that it will have to be made the type of a new group, related to that species, to the alatus and tampicoensis groups.

I desire to thank Mr. Chas. T. Simpson for the valuable aid given in the preparation of the above description and remarks.

\section{NOTES ON QUEBEC PUPIDE AND OTHER SHELLS.}

BY A. W. IINHAM, WINNIPEG, MAN.

My Quebec Pupide have just been looked over and separated for me by Dr. V. Sterki, to whom I am under many obligations for this labor of love. As a result my list of species, as far as these small things are concerned, requires some corrections and additions.

The following are the species taken, instead of as recorded on page 101, of the last volume of The Nautilus:-

Pupa armifera Say. As already recorded.

Pupa pentodon Say. As already recorded.

Sphyradium edentulum Drap. Not uncommon; Isle d'Orleans and St. Joseph's de Levis.

Vertigo ovata Say. As already recorded. 


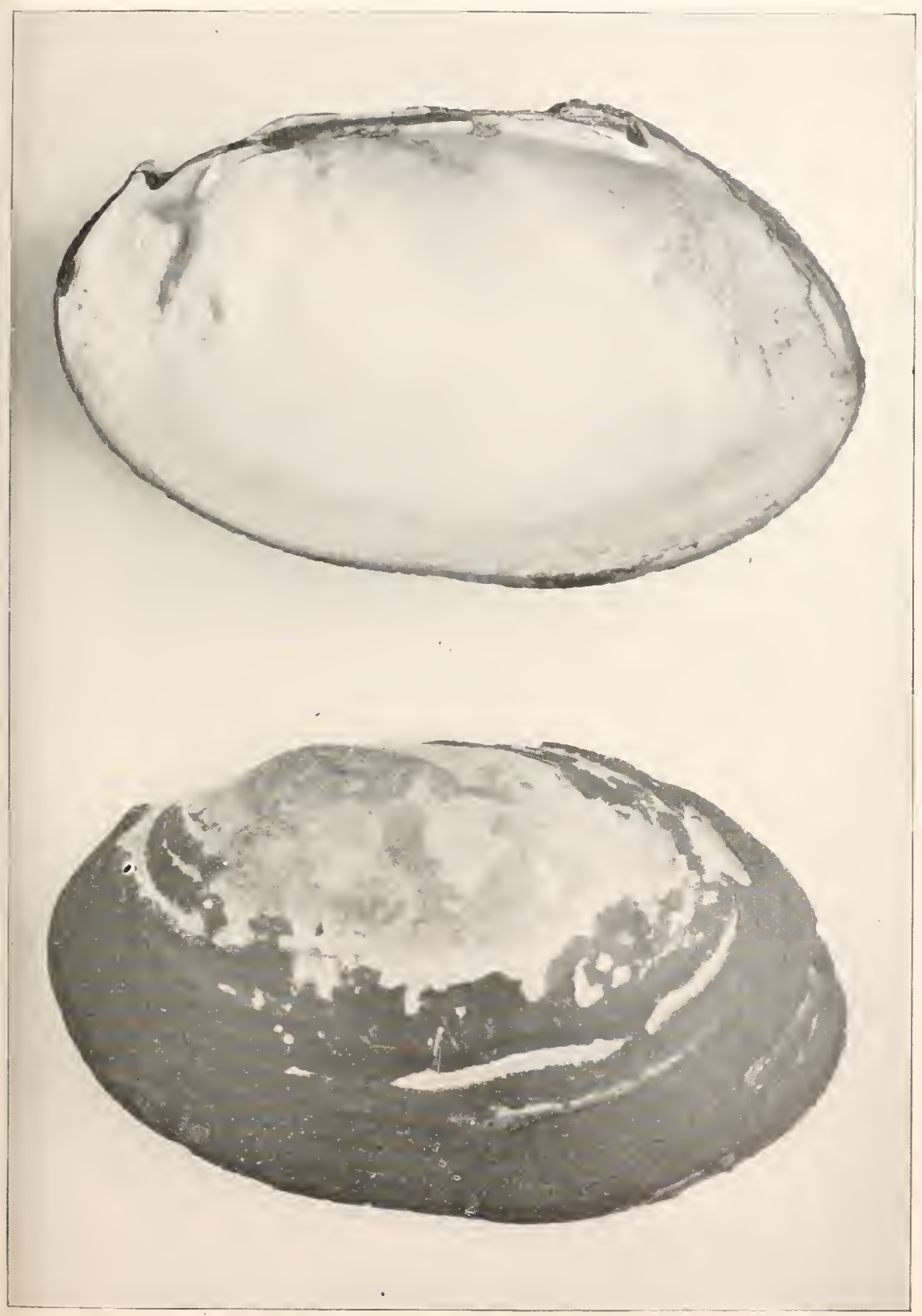

UNIO AMPHICHÆNUS FRIERSON. 


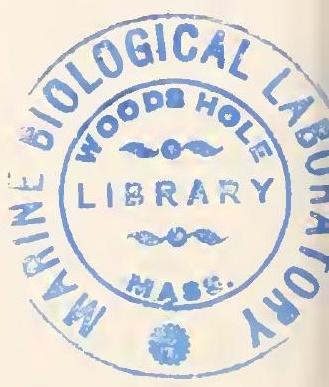


Vertigo gouldii Binn. The most abundant species taken. Common on mossy rocks at St. Joseph's and St. Romauld's (this species was confounded with bollesiana).

Vertigo ventricosa Morse. Nearly as common as gouldii, and taken at St. Joseph's and St. Romauld's, as well as on the Island.

Vertigo curvidens Gould. As already recorded.

Vertigo milium Gould. Very rare.

Vertigo pygmac Drap. Single example.

Vertigo tridentata Wolf. Single example.

A noticeable absentee from the above list is Pupa contracta, which however no doubt occurs in the Province.

Carychium exiguum Say. As already recorded.

Carychium exile Ad. One example.

Polygyra leai Ward. Referring to the valuable catalogue of North American land shells now appearing in Tue Nautuus, I am glad to see that this shell has been recognized as a distinct species, for such I have always considered it. The species extends into Canada. In the spring of 1891, at Brantford, Ontario, in drift along the Grand River, I noticed plenty of dead shells, but never came across any living ones until October. On the 9 th and 10 th of that month, shortly before leaving for Quebec, I got over 200 specimens from a small corner of swampy land-overgrown with reeds and bushesadjoining a sluggish stream. Zonites ligerus was in even greater abundance. Besides these species (rare in Canada) were taken: Selenites concava, Titrina limpida, several small species of Zonites, Pupa contracta, Succinea avara and ovalis, and a very handsome small form of S. obliqua, Pomatiopsis lapidaria, etc. A richer spot could hardly have been found. From a steep bank not far back from the stream, I got a number of pairs of Polygyra monodon, but no $P$. leai, and I did not find the former species with $P$. leai down below. The chief object of this note is to show the Canadian record.

\section{DESCRIPTION OF A NEW UNIO.}

BY BERLIN H. WRIGHT.

U. reclusus sp. nov.

Shell ovate-triangular, smooth, polished above, nearly equilateral, somewhat inflated. Substance of the shell moderate and quite uniform in thickness. Epidermis finely striate, rayless, brownish, with 
two or three distant growth lines. Beaks prominent and surrounded by four or five coarse, sharp, widely separated irregular undulations. Ligament reddish, short, thin and scarcely elevated above the dorsum. Dorsal margin slightly elevated; anterior margin gracefully rounded, base unifurmly and slightly curved; posterior margin pointed. Posterior area abrupt with two slightly raised lines formed of irregular elevations from beak to margin. Umbos gracefully and uniformly rounded; greatest diameter in the centre of the disk. Nacre sky-blue throughout, sometimes darker within the pallial line. Beak cavities slight and abrupt. Cicatrices well impressed, smooth and distinct. Cardinals solid, prominent, double in the left valve and single in the right valve, laterals double in the left valve and disposed to be double or tripartite in the right valve and joined to the posterior cardinal by a distinct elevation of the dorsal plate.

Width $1 \frac{3}{4}$ in., length 1 in., diam. $\frac{5}{8} \mathrm{in}$.

Habitat: Ocklocknee River, Leon County, Florida.

Type in National Museum.

Remarks:--This anomalous little shell was taken with $U$. kleinianus Lea, lienosus Con., kirklandianus IV right and floridensis Lea. It does not seem to group well with any known species, though the the beak sculpture indicates a relationship with $U$. forbesianus Lea. In some respects it reminds one of $U$. macrodon Lea, but it is more inflated, not as solid usually, darker in epidermis, rayless, with deeper beak and shell cavities. The lateral teeth are longer, higher and end more abruptly, besides being double or tripartite in the right valve. The very young show slight traces of broad, distant rays. It certainly groups with $U$. forbesianus Lea, but is easily distillguished from the young of that species by its want of rays, lighter epidermis, rounded base, rounded umbonal angle, flattened umbos and it is smoother on the posterior area.

\section{NEW PISIDIA.}

BY DR. V. STERKI.

Pis. singleyi n. sp.

Mussel small, rather high, somewhat oblique, ventricose, beaks prominent, also in the young, rounded but narrow on top, slightly posterior, vertical section broadly heart-shaped; superior margin moderately curved, rather short, scutellum slightly, scutum well 
marked; anterior part somewhat angular with the end rounded; posterior end rounded or slightly truncate, inferior margin regularly curved; shell thin, translucent, colorless to pale horn; surface very finely, almost regularly striated, somewhat shining; interior surface with fine but well marked, crowded pits, visible from the outside; hinge rather fine, plate narrow, cardinal teeth rather short but high, lamellar, the right one almost straight and longitudinal in its anterior part, thickened in the posterior and curved downward beyond the level of the plate; those of the left valve little curved, the inferior somewhat the larger and projecting downward over the edge of the hinge plate; lateral teeth rather small and thin, pointed in the middle and rather abrupt, in the right valve the anterior much the largest, slightly·projecting inward.

Long. $2 \cdot 5$, alt. $2 \cdot 3$, diam. $1 \cdot 7$ mill. (Texas).

Long. $3 \cdot 3$, alt. $2 \cdot 8$, diam. $2 \cdot 4$ mill. (Mexico).

Habitat: Texas, Mexico.

In shape, color and striation, it has some resemblance with $P$. punctatum, but the latter is much smaller, its surface is microscopically rugulose, dull, and the hinge comparatively stouter.

It was first seen in drift materials from the Guadalonpe River, Comal Co., Texas, collected and kindly sent by Mr. J. A. Singley in 1892 , represented by a fair number of specimens in all stages of growth. Then in drift from the same river, sent by Mr. IVm. A. Marsh, a few young specimens. Another lot from the Guadaloupe River is in the U. S. National Museum (No.134,010, Gurley), and under the same head must be ranged one from Itzlan Creek, Guadaljara, Mexico, (No. 102,215). Of the largest specimen of them the dimensions are given above. The species is named in honor of Mr. J. A. Singley.

\section{Pis. splendidulum n. sp.}

Mussel small, well inflated, rather ovoid in outline, scutum and scutellum rather well marked, the former often prominent; beaks slightly posterior, somewhat prominent, moderately large, rounded; color pale to deep horn, surface polished, with very fine, somewhat irregular striæ; shell thin, transparent; hinge rather fine but well formed, plate narrow; cardinal teeth longitudinal, lamellar, the right one rather long, slightly curved, most so at both ends, more or less thickened at the posterior end, and often with a groove; the two in the valve nearly equal, parallel, little curved, the superior is anterior for about one-third of its length; lateral teeth compara- 
tively strong, all projecting into the interior of the mussel, pointed; ligament rather long.

Long. 2·8, alt. $2 \cdot 4$, diam. $1 \cdot 7$ mill.

Hab. : Maine, Virginia, Michigan.

At Caribou, Aroostook Co., Me., mainly in the Barren Brook, $\mathrm{Mr}$. Ol. O. Nylander collected, and sent me for examination in different lots, more than three thousand specimens. Mr. H. W. Winkley collected some near Saco, Me., and in Mr. J. B. Henderson's collection are a few lots from Old Orchard, Me. Mr. L. H. Streng sent in different lots about 1200 specimens collected nearGrand Rapids, Michigan; and the writer has found it rather common in the Potomac River at Washington, D. C., as well as in different runs and ditches in Virginia near the National Capital.

Our species cannot be mistaken for any other Pisidium. In shape it has some resemblance with $P$. abditum and politum; but its small size, the color and transparency of the shell, the shape of the cardinal teeth, will readily distinguish it. In size, color and transparency of the shell, and the polished surface, it resembles $P$. ventricosum and vesiculare; but both the latter are much more inflated, their beaks are quite posterior and larger. It is, however, rather variable in size and coloration, and the striation of the surface.

(To be concluded).

ELWOOD PLEAS.

It is with sincere regret that we record the death of our old friend and correspondent, Mr. Elwood Pleas, of Dunreith, Henry Co., Indiana, which occurred on December 31, 1897. He was born May 4,1831 , and the greater portion of his life was spent in Henry County. For a number of years he was Editor of "The Newcastle Courier" and the old files of this and other papers bear ample evidence of his earnest ability as an editor. His most interesting articles were those pertaining to his favorite study, Natural History. Mr. Pleas was well known to many readers of The NautiLus, his principal contribution being "Shells of Henry Co., Indiana," (Vol. VII, page 65). In this article he recorded 123 species and varieties of land and fresh water shells found by him within a radius of five miles from his home. 
In Tile Nautilus (Vol. V, page 2), Mr. Wm. A. Marsh described two new Unios collected by him, of one of which, U. Pleasii Mr. Marsh says: "I name this shell after my friend, Mr. Elwood Pleas, of Indiana, who collected this species with many other rare shells in the interior of Arkansas." .

Mr. Pleas also collected extensively through Alabama and western Florida. Being interested in geology he availed himself of the opportunity while in Alabama of securing a large collection of Eocene fossils. Mineralogy, botany and entomology also received a share of his attention, and in his death nature has lost a sincere lover, and science an earnest supporter.-C. W. J.

\section{PUBLICATIONS RECEIVED.}

Cambrian Brachiopoda: Genera Iphidea and Forkia, with Descriptions of New Species of each, and of the Genus Acrothele, by Charles D. Walcott, (Proc. U. S. Nat. Mus., XIX, 1897). Iphidea is a genus of small brachiopods belonging to the Neotremata of Beecher, possibly with characters that nearly place it in the Protremata. The species, of which 14 are known, range from the lowest known Lower Cambrian horizon to the upper portion of the Middle Cambrian. Five new species are described. Forkia is a new genus of inarticulate brachiopods based upon a new species, $Y$. Wanneri, from the Lower Cambrian near York, Penna. Two new forms of Acrothele are also described.

Die Gehauseschnechen des Galberges und Krahnberges вег Gotha, von L. Schmidt, (Gratis-Beiblatt zu den "Gothaer Neuesten Nachrichten," Oct. 1, 1897). A list of 38 species of land snails making substantial additions to the Thüringian mollusk fama, the literature of which has been scant. The slugs have been omitted. Among the rarer species Azeca menkeana may be mentioned. There 24 Helices, including the Zonitida, all of them widely distributed species.

A Study of the Family Pectinide, with a revision of the genera and subgenera, by A. E. Verrill, (Trans. Conn. Acad., X, 1897). The most elaborate study yet made upon the system of this family is the subject of Professor Verrill's paper. The earlier fossil groups are not fully considered. In the Cretaceous nearly all existing generic and sectional groups had appeared, and probably none has 
been evolved since the Eocene. All of the larger forms have very numerous marginal tentacles on the mantle, corresponding somewhat to the external sculpture of the shell in position, and there is also a second inner row of "guard tentacles" on a raised inner pallial fold. The marginal tentacles are accompanied by a series of well formed pallial eyes, very lustrous when living, arid having a crystalline lens. These are also arranged according to the ribs of the shell. In some of the deep sea forms there are but few eyes, and in some cases they are not pigmented. Pectens, as is well known, are good swimmers, although the very inequivalve typical forms are rather sedentary. This probably enables them to escape the attacks of crabs, fishes, etc., as well as boring gastropods, for it is certainly true that bored Pectens are rarely seen.

The nomenclature is thoroughly sifted, and the genera and subgenera characterized, 27 being recognized, of which 8 are new. The subdivision seems rather minute to one accustomed to the old order of things, but has doubtless been well considered. Of the genera, Pecten restricted, scarcely occurs on our coasts. AursIUm is represented by a couple of deep sea forms, but the Oriental species is a well known shell. The subgenus Propeamusium contains small species such as Dall's alaskensis. Chramys, type islandicus, is well represented, C. irradians, dislocatus, etc., belonging here to the subgenus Equipecten. Liswopecten is a new subgenus proposed for C. hyalinus Poli, and Leptopecten anotler for C. monotimeris of California. Placopecten is proposed for P. clintonius Say, also as a subgenus of Chlamys. LrRopecten contains L. nodosus, subnodosus, etc. Pectinella is a new genus for P. sigsbei Dall of the West Indies in deep water. Crclopectex is a new genus for $P$. pustulosus Ver. and many other small species, mostly of deep water. Hyalopecten, n. gen., type $P$. undatus Ver., contains snall forms possibly related to the fossil genus Syncyclonema. Paranusium, type $P$. Dalli Smith, is another new genus.

Several new forms are described, with useful notes on others, among which we may mention with approval the rejection of Gmelin's misleading name magellanicus for the well known New England species. Verrill calls it Chlamys (Placopecten) clintonius Say. A very useful analytical key to the genera is given, and six well drawn plates illustrate important structural features and unfigured species. 
181. Strobilops virgo (Pils.). Canada to Northern Alabama and west to Minnesota and Kansas.

182. Strobilops affinis Pils. New York, Ohio, etc.

183. Strobilops hubbardi (Brown). Calhoun Co., Texas; Savannah, Ga.; Eastern and Northern Florida. Also Jamaica.

\section{Genus LEUCOCHEILA Martens.}

184. Leucocheila fallax (Say). Prov. Ontario, Canada, to Florida, and west to Minnesota, Texas and A rizona.

185. Leucocheila modica (Gld.). St. Simon's Island, Ga. to Florida; west to Cedar Keys and Ala.

\section{Genu: BIFIDARIA Sterki, 1891. \\ Section Albinula Sterki.}

186. Bifidaria armifera Say. Ontario and Quebec, Canada, and nearly the whole U.S. east of the Rocky Mts.

187. Bifidaria contracta Say. Ontario, Canada, and the whole U. S. east of the Rocky Mts. ; eastern Mexico.

188. Bifidari fiolzingeri Sterki. St. Cloucl, Minn., Iowa, S. to Wichita, Kansas and Joliet, Will Co., Ill.

188a. Bifidaria holzingeri fordrana Sterki. Wichita, Kansas.

\section{Section Bifuluria s. str.}

189. Bifidaria hordeacea Gabb. Arizona, New Mexico.

190. Bifidaria procera Gld. Minnesota to New Mexico, and eastward.

191. Bifidaria hordeachlea Pils. Comal and Lee Counties, Texas; New Mexico.

192. Bifidaria rupicola Say. Kansas and New York southward to Texas and Key West, Florida.

193. Bifidaria servilis Gld. Florida; Cuba.

(An undescribed form of this group has been called $P$. riograndensis Sterki. Hidalgo, Texas).

194. Bifidaria corticaria (Say). Ontario and Maine to Minnesota, south to South Carolina and Mississippi.

195. Brfidaria fiebes Ancey. New Mexico, Arizona, Nevada and Utah; type locality White Pine, Nevada. This is P. arizonensis W. G. B., not Gabb, and P. gubbi Dall. A form saxicola Ckll. has

${ }^{1}$ Not Pupa saxicola Lowe nor P. saxicola Moq.-Tand. 
been described from Round Mountain near Silver Cliff, Colorado.

195a. Bifidaria hebes mexicanorum Ckll. Mesilla, New Mexico.

\section{Section Vertigopsis 'Ckll.' Sterki.}

196. Bifidaria Pilsbryana Sterki. New Mexico, Arizona.

197. Bifidaria cincinnatiensis Judge. Cincinnati, Ohio.

198. Bifidaria curvidens Gld. Mass. to Mimn.; Ontario and Quebec.

198a. Bifidaria curvidexs gracilis Sterki. Rhode Island, Ohio, Tennessee.

198b. Bifidaria curvidens floridana Dall. Archer, Alachua Co., Florida.

199. Bifidaria Pentodon (Say). Ontario and Quebec, Canada, to Minnesota, south to Ga. and Texas; Lincoln Co., Nevada; Laggan, B. C. A form curta Sterki, occurs in Ohio.

Genus PUPA Draparnaud.

Subgenus Pupilla Leach, (=typical Pupa.)

200. Pupa muscorum (L.). Prov, Quebec, Canada, New England, and the Northern tier of States from Maine to Montana; Colorado, Utah and Nevada. Also Europe. Pupa sublubrica Anc. is considered a synonym by Binney.

201. Pupa blandi (Morse). New Mexico, Utah, Colorado and western S. and N. Dakota. (Referred to P. muscorum var. bigranata Rossm. by von Martens; cf. also P. signata Mouss.). A form obtusa Ckll. is recorded from Custer Co., Colo.

202. Pupa syngenes Pils. New Mexico; Arizona; Montana.

203. Pupa sterkina Pils. San Diego Co., Cal.; Lower California.

Subgenus Nearctula Sterki.

204. Pupa Califonica (Rowell). San Francisco, etc., California.

204a. Pupa Californica elongata Sterki. San Clemente Island.

204b. Pupa Califorica catalinaria Sterki. San Clemente and Santa Catalina Is.

204c. Pupa californica diegonnsis Sterki. San Diego, Cal.

204d. Pupa californica trinotata Sterki. Monterey, Cal. 
204e. Pupa califoricica crclops Sterki. Placer Co., Cal.

205. Pupa rowelli (Newc.). Middle portion of California, Oakland, Monterey, etc.

206. Pupa conpulenta (Morse). Vancouver Id. ; Washoe Co., Nevada; North Park, Colorado.

207. Pupa castanea Sterki. Lake Co., California.

208. Pupa decora (Gld.). Berkshire Hills, W. Mass. to Great Slave Lake. Rare and local.

208a. Pupa decora borealis (Norel.). Bering Island.

209. Pupa concinnula Ckll. Colorado at high elevations. ( $V$. ingersolli Ancey, unpublished, with varieties haydeni and perhaps accedens Anc., are identical. Perhaps P. montanella Ckll. undescribed, belongs here).

210. Pupa Coloradoexsis Ckll. Colorado, "mid-alpine."

211. Pupa hoppri Möll. Greenland; (? Anticosti Island; Laggan, near summit of Rocky Mts.).

212. Pupa columbiana Sterki. Washington. Undescribed. An undescribed var. utahensis is mentioned by Dr. Sterki.

Subgenus Sterkia Pilsbry, 1898.

213. Pupa calamitosa Pils. San Diego Co., Cal., and southward.

214. Pupa hemphilli Sterki. San Diego Co., Cal., and southward.

215. Pupa Clementixa Sterki. San Clemente Island, Cal.

Genus VERTIG0 Draparnaud.

Subgenus Angustula Sterki.

216. Vertigo milium Gld. Hamilton, Ont., Quebec, and Maine to Minnesota, south to Florida and Texas.

Subgenus Vertigo Drap.

Section Haplopupa Pilsbry, 189 s.

217. Vertigo dalliana (Sterki). Lake Co., California.

Section Bothriopupa Pilsbry, 1898.

218. Vertigo variolosa (Gld). Southern extremity of Florida. Section Vertigo s. str.

219. Vertigo binneyana Sterki. Manitoba to Seattle, Wash., south to New Mexico. 
220. Vertigo Pygmaa Drap. Quebec, New England and N. Y., south to Va., west to Columbus, Ohio. ( $=V$. callosa Sterki, not of Reuss, Palæontographica, II, p. 30, 1849).

221. Tertigo rugosula Sterki. South Carolina, Gulf coast to Texas.

221a. Vertigo rugoscla oralis Sterki (n. n. for ovulum Sterki preoc.).

222. Vertigo ovata Say. Eastern North America, Ont. and Quebec to Florida; Arizona, New Mexico.

223. Vertigo morser Sterki. Kent Co., Michigan ; Northwestern Olino.

224. Vertigo ventricosa (Morse). Quebec and Maine to Ohio.

224a. Vertigo ventricosa elatior Sterki. New Philadelphia, Ohio; East Saginaw, Mich., Clearwater, Minn.

225. Vertigo gouldi Bimn. Ontario, Quebec and Maine to Montana, south to N. J. and Md.

225. Vertigo approximans Sterki. Illinois.

226. Vertigo bollesiana (Morse). Maine to Iudiana, south to Virginia and Tenn.; mainly in the N. E.

226a. Vertigo bollesiana arthuri Martens. Little Missouri, Daknta.

227. Vertigo tridentata Wolf. Quebec and Maine to Minnesota, south to Illinois and Ohio.

228. Vertigo Parvula Sterki. Summit and Lake Counties, Ohio.

229. Vertigo oscariana Sterki. Florida to Texas; Tenn.

\section{Family ACHATINID洢.}

Genus OPEAS Albers, 1350.

230. Opeas micra (Orb.). Fort Dallas, Florida; Charleston, S. C. West Indies and South America. Stenogyra octonoides is a synonym.

231. Opeas subula (Pfr.). Mobile, Ala. West Indies. (Introduced in some greenhouses North).

[Opeas goodalli (Mill.) and all undetermined Opeas have been found in Plipp's conservatory, Pittsburgh (Clapp); and the latter occurs also in Washington, D. C. (Lehnert). Subulina octona lives in Horticultural Hall, Philadelphia. Until naturalized out of doors, these can hardly be regarded as belonging to our fauna, any more than the animals of zoological gardens.] 


\section{The Nautilus.}

\section{MOLLUSCA CONTEMPORANEOUS WITH THE MASTODON.}

BY BRYANT WALKER.

In The Nautilus for March, 1891, (Vol. VI, p. 131) there is given a list of half a dozen species of fresh-water shells which were found associated with the remains of a mastodon discovered in Randolph County, Indiana. Through the courtesy of Mr. WV. Hilles Smith of Niles, Michigan, I have recently had an opportunity of examining a quantity of material taken from the muck beneath the remains of a mastodon found near that city.

As the list of species is a considerable one it is of interest not only because of the circumstances, under which they were found, but also as a basis for comparison with similar finds from other localities.

As has been stated by others in reference to the mollusca formed fossil in the loess there is here, in most instances, little, if any, variation from the usual form of the species as they are found living at the present time.

The Planorbis companulatus Say and bicarinatus Say are both larger than the average size of the species as usually found. In the latter species there is a decided tendency towards a whorl narrow in proportion to its lieight, with a strong carina on both sides, resulting in a long narrow aperture in mature examples.

One of the most abundant species in the collection was Valuata tricarinata Say, which afforded some unusual forms. As is well known, this species is extremely variable in its sculpture, ranging though the bicarinate and unicarinate forms to that which is ecarinate. In this, however, all the specimens are strongly tricarinate and the variation is in the other direction and in the form of additional carinc. This, in one instance, appears as a fourth carina on the body whorl about half way between the snperior and peripheral carina in the normal shell. In another specinen, a fourth carina is sud- 
denly developed upon the shoulder of the last whorl parallel with superior carina and at about one-third of the distance between it and the suture. The interval between the two being a groove, rather than a continuation of the flat surface of the shoulder. In a somewhat similar specinen there is no distinct carina developed, but simply a sharp edge, where the flattened surface of the shoulder is cut by the groove which encircles it just inside the superior carina. In two other examples, the suture of the last half of the body whorl is decidedly channelled, increasingly so as it approaches the aperture, with an indistinct elevation hardiy sufficient to be termed a carina, bordering its outer edge.

Although these variations were found in only half a dozen specimens out of a considerable number, it is nevertheless worthy of notice, that in each instance the growth of the shell had been entirely normal until about the begiming of the last whorl. Then suddenly and apparently after a period of $r \in$ st, such as hibernation, with a renewal of growth the change of sculpture begins. This would naturally seem to be the result of some change in the environment. But, whatever was its source, it was not sufficient, evidently, to affect the whole colony. However, as some of the examples are not fully grown, it may be possibly attributed to the same cause, which very shortly exterminated them all. Unfortunately, what that was, is purely a matter of conjecture.

The complete list of the species found is as follows:

\section{Zonites radiatulus Ald.}

Strobilops labyrinthica Say.

Succinea ovalis Gld.

Carychium exiguum Say.

Linınæa stagnalis $\mathrm{L}$.

Limnea desidosa Say.

Limnea humilis Say.

Physa ancillaria Say.

Physa heterostropha Say.

Physa integra Hald.

Planorbis deflectus Say.

Planorbis parvus Say.

Planorbis bicarinatus Say.

Planorbis trivolvis Say.

Planorbis campanulatus Say.

Ancylus rivularis Say. Valvata tricarinata Say. Amnicola limosa Say.
Anmicola lustrica Pils.

Campeloma in tegra Say.

Campeloma obesa Lewis.

Campeloma subsolidum Anth.

Pleurocera elevatum Say.

Goniobasis livescens Mlke.

Unio ventricosus Bar.

Unio spatulatus Lea.

Unio novi-eboraci Lea.

Unio pressus Lea.

Margaritina rugosa Bar.

Margaritina deltoidea Lea.

Anorlonta subcylindracea Lea.

Anodonta Footiana Lea.

Sphærium simile Say.

Sphærium striatinum Lam.

Pisidium compressum Prime.

Pisidium sp. 


\section{HAWAIIAN CYPREID压.}

BY D. D. BALDWIN, IAIKU, MAUI, H. I.

In the following list of species reported from these Islands, those not known to me personally as Hawaiian are marked with an asterisk :

Cypræa annæ Roberts.* Cyprea annulus Linn. Cyprea arabica Linn. Cyprea argus Linn. Cyprea carneola Linn. Cyprea caput-auguis Phil. Cyprea caput-serpentis Linn. Cyprea childreni Gray. Cyprea cicercula Linn. Cyprrea erosa Linn. Cyprea errones Linn. Cypræa fimbriata Gmel. Cyprea helvola Linn. Cypræa isahella Linn. Cyprea intermedia Gray. Cyprea limacina Lam.* Cyprea lynx Linn. Cyprea madagascariensis Gmel. Cyprea mauritiana Linn. Cypræa moneta Linn. Cyprea microdon Gray.
Cyprea nucleus Linn. Cypræa polita Roberts. Cyprea poraria Linn. Cyprea reticulata Mart. Cyprea spadix Migh.* Cyprea scurra Chem. Cyprea semiplota Migh.* Cyyrea staphylea Linn.* Cyprea sulcidentata Gray.

Cyprea talpa Linn. Cyprea tessellata Sow. Cyprea tigris Linn. Cyprea unifasciata Migh.* Cyprea ventriculus Lam. Cyprea vitellus Linn. Trivia exigua Gray.* Trivia grando Gask. Trivia globulus Linn.* Triria insecta Migh. Trivia oryza Lam.* Trivia sphærula Migh.*

\section{NEW VARIETIES OF UNIONID曆.}

BY BERLIN H. WRHGHT.

U. gibbosus Barnes, var. armathwaitensis nov.

The chief distinguishing characters of this variety are: Broader behind, lateral teeth shorter, darker epidermis, beak cavity more pronounced and angular, longer, posterior cavity greater, nacre usually a brighter purple and it is never as large or as massive as the typical form.

Habitat.-A branch of the South Fork of the Cumberland River at Amathwaite, Fentress Co., Tenn. Type in National Museum.

Remaiks.-Mr. E. F. Hassler collected a quantity of these shells 
along with Margaritana ravenelliana Lea and they seemed to differ from $U$. gibbosus Bar. sufficiently to warrant making a variety of them, in which opinion Mr. Simpson of the National Museum concurred. Its place is between U. subgibbosus Lea and U.gibbosus Barnes and while it occasionally has the white nacre of the former species it is always larger but less massive, wider and has a darker epidermis.

It is also related to $U$. stonensis Lea and closely resembles that species except in epidermis and nacre. Only three specimens out of fifty had a pure white nacre, and those would be taken for stonensis but for the darker epidermis.

Margaritana marginata Say, var. truncata nov.

Shell abruptly truncated behind, and more produced in front, causing it to be nearly equilateral. More inflated and usually larger than the typical form.

Remarls.-This well masked variety was noted by Mr. Say and specimens were by him labelled in this name, but no description was ever published, so far as known. It occnrs in eastern as well as western waters and into Virginia and Tennessee.

\section{DESCRIPTIONS OF NEW PISIDIA.}

BY DR. Y. STERKI.

Pis. splendidulum Sterki.

Additional localities are: Upper Red Hook, N. Y., and New Philadelphia, Ohio.

Pis. abyssorum Stimpson, n. sp.

Mussel small, moderately inflated, somewhat elongate and oblique (most specimens somewhat rhombic), superior and inferior margins moderately curved; scutellum slightly, scutum rather well marked; posterior end rounded or slightly truncated above obliquely in postero-anterior direction, merging into the inferior margin with one continuous curve; anterior end a rounded angle situated rather inferiorly; beaks slightly posterior, rather low, comparatively broad; color whitislı to pale horn; surface polished, witlı fine, irregular strix; shell very thin, translucent; hinge very fine, plate very narrow; cardinal teeth short, lamellar, thin, longitudinal, scarcely curved, the superior of the left valve little anterior, quite small or abortive; lateral teeth very thin, not high, the outer oncs of the right valve scarcely perceptible or absent; ligament small. 
Long. 2·4, alt. 2.0, diam. $1 \cdot 4$ mill., (long. 2-3 mill.); young, as contained in parent, 0.8 mill. long.

Habitat: Region of the Great Lakes, in deep water.-Lake Michigan: Racine, Wis., dredged (Mr. Geo. T. Marstou); different places on the Michigan side, partly from a depth of $2+$ meters; Pine Lake, Mich., dredged; Green Lake, Wis., dredged ; from stomachs of White Fish, Lake Michigan, all sent by Mr. Bryant Walker, in 1894 , and partly since. They were believed be a new form, but publication was deferred.

In March, 1895, Mr. Geo. T. Marston sent me two lots from dredgings, writing: "No.,A. 208, Pis. abyssorum Stimpson, were from Dr. P. R. Hoy, Racine, Wis. He wrote me that they were first found in the stomachs of White Fish taken in Lake Michigan, near Racine, Wis., in 1870 , by a party of gentlemen inchuding $\mathrm{W} \mathrm{m}$. Stimpson and himself. The party were investigating the food of White Fish, then unknown. I quote from Hoy's letter: 'In 1870 we dragged in Lake Michigan- $\mathrm{Wm}$. Stimpson assisted-we got several of the Pisidium and three species of Crustaceans, all of which were new. Stimpson described the several new species-the names were published-I do not recollect where published-but the description was written out with the greatest care and were to be published in the Proc. of the Chicago Acad. Sc, of which Stimpson was secretary at the time. All were burnt at the time of the great fire.'" Mr. Marston subsequently had correspondence with several conchologists, but the matter remained unsettled. The two lots contained different forms of small Pisidia mixed up; but the most numerous and most conspicuous specimens represented the form now described under Stimpson's name. There is no absolute certainty that this is the same Pisidium the author had described, but it is the nearest in probability, and so to-day by the efforts of MIr. Marston, we can do justice to the deceased scientist. For the above description the writer is wholly responsible. The name (only) Pis. abyssorum has been published by Smith in his "Sketch of the Invertebrate Fauna of Lake Superior," according to a kind communication of Mr. Bryant Walker.

The form comes nearest Pis. splendidulum, in size and shape; but it is less inflated, the beaks are less prominent, the color is much paler (whitish), the shell thinner, and the hinge much finer and, as mentioned, partly defective.

Pis. pauperculum var. Nylanderi $n$.

Different from the type in the following points; it is comparatively 
higher (as high as long, or nearly so), quite oblique; the beaks are very large; upper margin and hinge very strongly curved; color pale greenish horn; surface highly polished, with distinct, irregular lines of growth.

Known from Maine and New Jersey. It has been collected in Partridge Lake, in the thoroughfare between Partridge and Long Lakes, in Long Lake, Square Lake, all in Maine, with the dredge, in various depths down to 25 feet, by Mr. Olof O. Nylander. Also dredged in White Pond, N. J., hy Messrs. Pilsbry and Rhoads, together with rather typical specimens of pauperculum and intermediate forms. The upper margin and hinge are as strongly curved as in Pis equilaterale $\operatorname{Pr}$. and some forms of $P$. compressum Pr. The beaks are so large as to make out almost the whole upper part of the mussel.

This Pisidium has been named after Mr. Ol. O. Nylander, who has so assiduously collected both recent and fossil mollusea of northern Maine.

New Philadelphia, Ohio., Jan., 1898.

\section{PUBLICATIONS RECEIVED.}

Catalogue of the Hatfield collectiox of Shellas from THE Loyatis Islaxds, by James Cosmo Melvill and Robert Standen. Originally published in the Journal of Conchology, this paper has been reprinted as one of the Manchester Museum Handbooks. The Loyalty Islands belong to the New Caledonian group, and like that island are remarkably prolific in mollusk life. A bout 600 species, of which a score are new, are catalogued by Messrs. Melvill and Standen. Some idea of the wealth of the fauna may be obtained from the fact that there are 42 species of Conus, 53 mitras, 46 Cyprea and Trivia (among them C. pxanthema L.' Rashleighana Melv., sulcidentata Gray, aurora (aurantium), clandestina v. Artuffeli Jouss., poraria var. albinella (new), Trivia childreni, etc.). Other interesting species are Turbo molnccensis and the Pleurotom$i d a$, of which a large number of small species, including numerous new ones, occurred. Two exce it platesillustrate new forms. The work is very creditable to Mr. an. 'Trs. Hatfield, who collected the shells, as well as to the authors.

Mr. G. B. Sowerby announces the issue of a supplement to his "Marine Shells of South Africa."

\footnotetext{
${ }^{1}$ Probably not indigenous.
} 
Subgenus Melaniella Pfr., 1859.

232. Opeas gracihlima (Pfr.). Key West, and near Miami River, Florida. Cuba, etc.

\section{Genus RUMINA Risso, 1826.}

233. Rumina decollata (Linir.). Charleston, S. C. Introduced from southern Europe.

Genus CECILIOIDES (Fér.) Hermannsen, 1846.

234. Cecilioides acicula (Müll.). Florida (Bartlett, many years ago); Princeton, N. J. (A. D. Brown). Introrluced from Europe.

\section{Genus COCHLicopa (Fér.) Risso, 1826.}

235. Cochlicopa lubrica (Müll.). Camada to D. C. and Alabama, west to Oregon. Also Palæarctic. Commonly known in America as "Férussacia subcylindrica L."

235a. Cochlicopa lubrica morseana (Doherty). Hamilton Co., Ohio; Kenton Co., Ky.; Roan Mt., N. C.

(Superfamily AGNATHA Mörch.)

Family GLANDINID床.

Genus GLANDINA Schum.

233. Glandina truncata (Brug.). Georgia Sea Islands to Florida, west to Louisiana and Mississippi. Forms macer Dall; parallela IV. G. Binn., Florida. Form bullata Gld., Lonisiana and Mississippi. Var. ovata Dall, Florida, is the same.

234. Glandina texasiana (Pfr.). Brownsville, Texas. Probably a mere form of truncata.

235. Guandina singleyana W. G. B. South central and southern Texas. ( $G$. decussata Desh. is a Guatemalan species).

236. Glandina ranuxemensis Lea. Texas?; Mexico. A doubtful nember of our fauna.

\section{Family TESTACELLID无.}

237. Testacella haliotibea I)rap. Roxborough, Philadelphia, Pa. Introduced from Europe.

\section{Family CIRC̣T, IRIID压 Pilsbry. \\ Genus CIRCINARIa (Beck, 1837) Pilsbry.}

(Macrocyclis auct. not Beck; Selenites Fischer not Hope; Hap. lotrema Anc.). 
238. Circinaria hemphilli (W. G. Binn.). Olympia, Wallawalla and Freeport, Wash.; also Oregon.

239. Circinaria concava (Say). Ontario and Quebec, Canada, west to Minnesota, south to Kansas, Mississippi and Georgia.

240. Circinaria vaxcourerensis (Lea). Bolinas Bay, Cal, to Sitka, Alaska.

240a. Circinaria vancourerexsis occidentalis (Hemph.). Sonoma to Santa Cruz Co., Cal. ; Kalama, Wash.

S. concavus var. tenuis Hemplr., from Napa Co., is practically the same. Mr. Hemphill has described a var. keepi from near Oakland, Cal. I have not seen specimens.

241. Circinaria sportella (Gld.). Klamath and Humboldt Co., Cal., to V'ancouver I.

241a. Circinaria sportella hybrida (Ancey). Portland, Astoria. The Dalles and Douglas Co., Ore.; Olympia, Freeport, and Seattle, Wash.; Vernon, B. C.

(This is M. vancouverensis var. hybrida Anc., 1888, and S.vanconcerensis var. hybridus Hemph., 1890).

24 . Circinaria royana (Newc.). Shasta Co., Cal. to Puget Sound.

242a. Circinaria voyana simplicilabris Ancey. California. 243. Circinaria duranti (Newc.). Santa Barbara Is. and coast range of southern California.

243a. Circinaria duranti Calata (Mazyck). San Diego, Cal. to San Tomas River, Lower California. (C'alatura W. G. B., Terr. Moll. V, 3d Suppll.).

243b. Circinaria duranti Catalinengis (Hemph.). Santa Catalina Island.

24t. Circinaria trangfuga (Hemph.). Sam Diego, Cal. to Todos Santos Bay, Lower California.

\section{(Superfamily A ULACOPODA Pilsbry.)}

Family ZONITID必.

Subfamily Zonitinæ Pilsbry.

Genu: OMPHALINA liafinesque.

245. Omphalina kopnodes (IV. G. Biun.). West Virginia to Ga. and Alabama.

246. Onphalina fuliginosa (Griff.). Ontario, west to sontlem Michigan, Indiana and Arkansas, south to Volusia Co., Fla. 
$246 a$. Omphalina fuliginosa polita Pilsbry. Mountain region of Eastern Tennessee and western North Carolina. Great Snokies; Monroe Co., Tenn.

247. Ompitalina friabilis (IV. G. B.). Southern Illinois to Washington Co., Texas; northern Kentucky ; Franklin Co., Tenn. 248. Onphalina levigata (Pfr.). North Carolina to St. John's Valley, Fla., west to Arkansas and western Lonisiana.

249. Ompinalina rugeli (IV. G. B.). North Carolina, Roan Mit. to Cranberry.

250. Ompitalina subplana (Binm.). Mts. between Tennessee and North Carolina.

251. Omphalina inoritata (Say). Ottawa and Hull, Canada, to Georgia and Ohio.

252. Omphalind axdrewse Pilsbry. Great Smoky Mits., between Tennessee and North Carolina; Macon Co., Ga.

25:a. Omphalina andrewse montraga Pilsbry. Thunderhead MIt.

\section{Genus VITRINIZONITES W. G. Binney.}

253. Vitrinizonites latissimus (Lewis). Mountains between Tennessee and North Carolina.

Genus VITRINA brap., 1801.

254. Yitrina limpida Gla. Canada and New England, west to Manitoba, south to Pittsburgh, Pa.

255. Vitrina pfeifferi Newc. California to B. C. ; New Mexico, Utah, Colorado.

256. Vitrina angelic.e Beck. Godharn, Greenland.

257. Vitrina exilis Morel. Unalaska; Bering Id. A Kamchatkan species.

\section{Genus VITREA Fitzinger.}

258. Vitrea cellaria (Müll). Seaports of Atlantic and Pacific coasts, Quebec, Portland, Me., Phila., Charleston, S. C., oceasional in greenhouses inland, Allegheny City, Pa., Detroit, Mich., etc.

259. Vitrea draparnaldi (Beck.). Greenhouses, etc., Seattle, Wash., Oakland, Cal.

260. Vitrea hamionis (Ström). North Carolina to Colorado, northward throughout the northern states and British Arnerica; also Paliarctic. (Hyalina pellucida Lehnert, H. viridula Mke., $H$. radiatula Ald., $H$. electrina Gild. are synonyms). 
261. Vitrea wheatleyi (Bland). Knoxville, Tenn., northern Alabama. (Indiana and Michigan, Sterki).

261a. Vitrea wheathey clingmaxi Dall. Clingman's Dome, Great Smoky MIts, N. C.

262. Vitrea raderi Dall. Cumberland, Md.

263. Vitrea petrophila (Bld.). Knoxville, Tenn.; Habersham Co., Ga.; Clarkesville, N. C.; Great Smoky Mts.

264. Vitrea binneyana (Morse). Quehec and Maine to northeru Mich.; also reported from Vancouver Id.

265. Vitrea johnsoni Dall. Seattle, Washington.

266. Vitrea whitseyi (Newc.). Near Lake Tahoe, Cal.

267. Vitrea diegoessis (Hempl.). Near Julian City, Cuyamaca Mts., San Diego Co., California.

Section Striatura Morse, 1864.

268. Vitrea ferrea (Morse). Quebec, Ontario and Maine to Northern Mich., south to Ohio and North Carolina.

Section Glyphyalina Martens, 1892.

270. Vitrea indentata (Say). Dakota to New Mexico, Lower California and states of Jalisco and Morelos, Mexico, east to the Atlantic, Ontario to Florida.

271. Vitrea sculptilis (Bld.). Mountain region near the Temnessee and North Carolima boundary.

272. Vitrea Carolinensis (Ck1l.). Mountain region along the North Carolina and Tennessee boundary; Mouroe Co., Tenn.

273. Vitrea subrupicola (Dall). Clinton's Cave, Utah.

273a. Vitrea subrupicola spelata (Dall). Cave City, Calaveras Co., Cal.

\section{Section Paravitrea Pilsbry, 1898.}

274. Vitrea capsella (Gld.). Virginia and Kentucky to Alabama.

275. Vitrea smpsoni (Pils.). Limestone Gap, Indian 'Terr.; Mablevale, Ark.

276. Vitrea Placentula (Shuttl.). Great Smoky Mts., etc., Eastern Tenmessee; Lexington, Va.; Hot Springs, Ark.

277. Vitrea lawf (IV. G. B.). Eastern Tennessee.

Genus CONULUS Fitzinger, 1833.

(Not Conulus Klein, pre Linnæan, nor of Raf., 1815, a nude name). 
278. Conulus fulvus (Müll.). All the States; British America, Palæarctic.

278a. Conulus fulyus dentatus Sterki. Jackson Co., Ala.; Cincinnati, Ohio.

279. Conulus sterki Dall. New Philadelphia and Summit Co., Ohio ; Mt. Lebanon, La. ; Jackson Co., Ala.

280. Conulus chersineluus (Dall). Calaveras Co., Cal. ; Fresno $\mathrm{Co}$.

Genu: GUPPYA Mörch, 1\$67.

281. Guppra guxdlachi (Pfr.). Florida; Hidalgo, Texas; also West Indies and Central America.

\section{Subfamily Ariophantinæ Pilsbry.}

Genus ZONITOIDES Lehmann, 1862.

282. Zoxitoides vitidus (Müll.). British America and Northern States from New England to Washington; Pa.; Ohio; Ala. Also Europe.

283. Zonitoides arboreus (Say). All the States; British America north to Great Slave Lake.

284. Zonitoides dallianus (Simp.). Manatee Co. and Little Sarasota Bay, W. Florida.

\section{Section Pseudohyalina Morse, 1864.}

285. Zonitordes Limatulus (Ward). New York, Ohio, Michigan, Indiana, local and rather rare. (San Mateo, Cal., Bimney).

286. Zonitordes iateumbilicatus (Pils.). Near Woodville, Jackson Co., Ala.

287. Zonitoines patuloides (Pilsbry). Thunderhead, Great Smoky Mits.

288. Zonitoines shimekil (Pils.). Loess of Iowa (Extinet).

289. Zonitomes selenitoides (Pils.). Mariposa Big 'Trees, Cal.

290. Zonitoides minusculus (Binn.). Ontario to Florida, west to Mont., Arizona and New Mexico.

290a. Zonitoides minusculus alachuants (Dall). Alachua Co., Fla.

291. Zonitordes leviusculus (Sterki). Comal Co. and Hidalgo, Texas; Henry Co., Ind.; N.-IV. Ohio; New Mexico.

292. Zonitoides singleyanus (Pils.). Comal Co., Central Texas; IToodville, Ala. 
293. Zonitordes exiguus (Stimps.). Quebec and Ontario, New England, N. Y., Mich.

294. Zonitoides Milium (Morse). Ontario to Florida, west to Indiana.

294a. Zonitoines milium PUgetensis (Dall). Seattle, Wash.; Ballena, San Diego Co., Cal.

fienus GASTRODONTA Albers, 1850.

295. Gastrodonta intertexta (Bimn.). Ontario to Florida, west to soutluwestern Louisiana and Indiana. A carinated form occurs.

296. Gastrodonta acerra (Lewis). Roan Mt., North Carolina, to Montgomery, Ala.; Indian Terr.

297. Gastrodonta demissa (Bimn.). Western Pa. to Georgia west to Arkansas and eastern Texas.

297 a. Gistrolonta demissa brittsir (Pils.). Hot Springs, Ark. 298. Gastrononta cerinoidea (Antli.). Virginia to northern Florida.

299. Gastrodonta Ligera (Say). Ontario to Michigan, Indian Terr. and Louisiana, south to Virginia and Tennessee.

300. Gastrodonta colliselia Pils. Lookout Mt., Roane, Knox, Monroe and Washington counties, Tennessee; Lexington, Va.

300a. Gastrodonta collisella percallosa Pils. Near Clattanooga and Nashville, Tenn.

301. Gastrodonta gulaisis (Say). Mountain region of eastern Tennessee, western North Carolina, northern Alabama and Georgia.

301a. Gastrononta gularis cuspidata (Lewis). Monroe Co., etc., eastern Tennessee; Roan Mt.

302. Gastrodonta suppressi (Say). Ontario and Michigan to Maryland.

303. Gastrononta macilenta, (Shuttl.). MIountains near the 'Tennessee and North Carolina boundary.

304. Gastrodonta lasmodon (Plillips). Eastern Tennessee, western North Carolina and northern Alabama.

305. Gistrodonta elliotti (Redf.). Same distribution.

306. Gastrodonta interna (Say). Ohio to northern Florida, chiefly in Tennessee; West Virginia; northern Alabama.

Sulygenus Taxeodonta Pilsbry, 1898.

307. (Gastrodonta significans (Bld.). Fort Gibson, Indian Terr.; Union Co., Tenn. 


\section{The Nautilus.}

Vol.. XI.

APRIL, 1898.

No. 12.

\section{DESCRIPTIONS OF NEW AMERICAN LAND SHELLS.}

BY HENRY A. PILSBRY.

Punctum clappi n. sp.

Shell minute, openly umbilicated, yellowish-brown, with depressed, nearly level spire, and cylindroid whorls. Whorls $3 \frac{1}{2}$, the earlier $1 \frac{1}{2}$ smoothish, finely pitted, the last 1 or $1 \frac{1}{\frac{1}{1}}$ whorls sculptured with elevated lamine runuing with the increment-lines, 30 to over 40 on the last whorl, the intervals closely striated and showing fine spiral striation; suture impressed, descending. in front; umbilicus deep and open, its width contained between $3 \frac{1}{3}$ and $3 \frac{1}{2}$ times in greatest diameter of shell. Aperture short oval, higher than wide, somewhat oblique, but little excised by the previous whorl.

Alt. $1 \cdot 1-1 \cdot 2$, greatest diam. $2 \mathrm{~nm}$.

Seattle (Randolph) and Tacoma (Hemphill), Washington ; Salem, Oregon (Hemphill).

My attention was called to this form some years ago, but its determination at this time is due to Mr. George H. Clapp, who insisting that the shells were neither Punctum conspectum nor Pyramidula astericus, induced me to review the group.

$P$. (Planogyra) asteriscus is even flatter above; the umbilicus is wider, one-third the diameter, and more open; the cuticular lamellæe are more widely spaced and fewer, 19-25 on the last whorl, and the aperture is relatively smaller.

Punctum conspectum, which also occurs at Seattle, has a much more elevated spire, decidedly narrower umbilicus, less than onefourth the diameter of the shell, and the aperture is different in shape, wider than high. 
On some specimens of $P$. clappi the elevated lamella are in part subobsolete.

Dentition not yet examined, so that the species may turn out to be a Planogyra rather than a Punctum.

Punctum californicum n. sp.

Similar to $P$. conspectum in the small, deep umbilicus and color. Spire somewhat more elevated; whorls fully 4, closely revolving, the last decidedly narrower than in conspectum (viewed from above). Surface lusterless, with fine, even, hair-like striation, and in places showing faint traces of spiral striæ. Umbilicus narrow and deep, its width contained $4 \frac{1}{3}$ times in greatest diameter of the shell. Aperture wider than high, shaped much as in $P$. conspectum.

Alt. $1 \cdot 14$, greatest diam. $185 \mathrm{~mm}$.

Fish Camp, Fresno Co., California.

Gastrodonta (Taxeodonta) lamellidens n. sp.

Shell similar to G. multidentata, but larger, with an additional whorl, and instead of radial rows of teeth having partition-like radial barriers, generally three in the young, one, not far within, in the adult shell. Alt. $1 \cdot 6$, diam. $3.7 \mathrm{~mm}$.

Thunderhead, Great Smoky Mts.

This is one of Mr. J. H. Ferriss' finds. It was only obtained in small numbers, but probably is abundant, overlooked on account of the small size. I have not heard of $G$. multidentata being found so far south as this.

Gastrodonta collisella percallosa n. var.

Shell similar to $G$. collisella or a small ligera with globose base; having an extremely heavy callus within the outer and basal walls of the aperture, extending about one-third whorl inward; no lamella. Whorls $7 \frac{1}{3}$. Size of G. collisella.

Mr. Geo. H. Clapp, of Pittsburgh, Pa., when in Philadelphia lately, called my attention to this form. Upon examining the collection of the Academy, two trays of it were found, one set collected by A. G. Wetherby (who also supplied Mr. Clapp's specimens), on the Tennessee river, 3 niles above Chat tanooga, Hamilton Co., the other by G. A. Lathrop, at Nashville, Tenn. In correspondence with Mr. Wetherby some years ago, we mutually agreed that the shells were a small, heavily calloused variety of $G$. ligera; but upon reconsideration I am disposed to rank them rather with $G$. collisella. 


\section{A NEW SUBGENUS OF CORALLIOPHAGA.}

BY W. H. DALL.

Oryctomya n. subg.

Shell with the form of Coralliophaga, the surface with radiating very fine lines of minute granulations as in Euchoris; hinge with one slender, transverse, more or less trifid cardinal in each valve, that in the left valve larger, and a slender almost linear tooth on the anterior lower surface of the nymph in each valve; an obscure projection on the cardinal nargin in front of the cardinal in the left valve; no lateral teeth; pallial sinus slıort, angular, the adductor scars large and strong, the inner margins of the valves plain. Type C. (O.) claibornensis Dall.

This subgenus differs from Coralliophaga in its surface and dentition, and has the pallial sinus more distinct and angular. It las the boring habit, the valves are therefore often irregular, the younger ones are thinner, more regular, and with the adductor scars less evident. Coralliophaga prima Harris (Bull. Pal. IX, p. 60, pl. 13, figs. 4, 5, 1897), from the Lignitic, may be congeneric, but I lave seen no specimens, and the dentition is different according to the description.

c. (Oryctomya) claibornensis Dall.

Shell elongate oval with low beaks, quite anterior, moderately inflated, somewhat mesially impressed; surface with incremental lines which in senile specimens sometimes become lamellose near the posterior end; radial sculpture of rows of small globular grautes easily worn off and almost microscopic; ends rounded, the posterior broader; hinge teeth delicate, somewhat pedunculate and slender in the adult; pallial sinus not extending in front of the posterior adductor scar; pallial line in senile specimens radially striated.

Lon. 36, alt. 19, dian. $14 \mathrm{~mm}$.

Claiborne sands, at Claiborne, Ala., Burns.

This species is readily recognized by its peculiar surface. It will be illustrated in a publication now in press.

\section{NOTES AND NEWS.}

How Can He Crean'em?-A collector asks "How can I get the livers out of my shells? Is there an acid that will eat liver and 
let the shell alone; or, is there some absorbent that will contract when cool or in the process of drying that will bring it out? I have put my snails in boiling water, guessing at the cooking necessary for the different varieties, but often I cannot extract the whole animal, leaving a portion to discolor the spire."

For cleaning the exterior of water shells I find fine table salt about the correct thing. Rub it on with a piece of cloth or the hand. It has grit enough to remove lime, algæ and iron stains without being firm enough to scratch the epidermis. Often a weak solution of muriatic acid assists in removing iron stains and lime, and brightens the colors. Rinse thoroughly, and when dry rub over lightly with raw linseed oil.-JAs. H. Ferriss.

Notes on some Pupide.-The perusal of the account of the Pupidæe in the new Catalogue suggests the following comments. Pupa montanella (p. 119) is not concinnula, but is a weak form of pentodon, found in Custer Co., Colorado. The name has never been sanctioned by a description, and should be dropped. $P$. pentodon, it may be remarked, was originally the type of Vertigopsis, as I had it in my MS.; but in Nautruds, January, 1893, Dr. Sterki takes curvidens as the type, and this must now hold good. Ancey's unpublished descriptions of his two forms of $P$. ingersolli are as follows:

"Var. (?) haydeni Anc. Testa precedenti [ingersolli] statura formaque simillima, sed dentibus palatalibus 3 parallelis et æqualibus, elongatis, nec. 2, discrepans. Cunningham Gulch (Ingersoll)." "Var. accedens, Anc., Testa typo similis, sed tuberculo parietali distincto prope dentem armata." (May, 1890). Pupa sublubrica is hardly muscorum; a figure communicated by Mr. Ancey shows, besides a strong parietal tooth, one on the outer wall, and also an obtuse one on the columella. The figure appears to me to represent a form of blandi. In May, 1890, Mr. Ancey (in litt.) states that hebes was near to muscorum, and criticised Binney for putting it under arizonensis; thus it appears probable that gabbi may stand. At that time (1890) a new name was proposed in MS. by Ancey for arizonensis, IV. G. B., but it was not published. It may be as well to remark here that the name Holospirc romeri var. minor, published (Nautilus, VI, 6) by Dr. Sterki, without description, belongs to IV. G. Binney's var. 3 , Man. Amer. Land Shells, p. 422.-C'T. D. A. Cock kreli. 


\section{RECENT PUBLICATIONS.}

Appendix to Marine Shells of South Africa, by G. B. Sowerby (30 pp., $3 \mathrm{pl}$.). The total number of species is brought up to 1051 in this appendix. Among numerous new forms may be mentioned $F u l g u r$ africanum, a form resembling young $F$. carica; two fine Ancillas, a Basterotic and several new forms of Scintilla as as of special interest. The rare Voluta festiva Lam. is also recorded.

Armature of Helicoid Land Shells. Mr. G. K. Gude still continues his series of articles under this head in Science-Gossip. The extensive genus Plectopylis still furnishes species for description and illustration. In this group, as in many other genera of land suails, the most important characters for distinguishing species, and for their grouping, are to be seen only by cutting the shell to expose the peculiar system of internal barriers and teeth. In some species of Plectopylis these are wonderfully complex, forming truly a "crooked gateway." It must be said that in these papers Mr. Gude supplies a large amount of information not elsewhere to be found.

The Varfations and Mutations of the Introduced LitTorina, by Hermon C. Bumpus (Zool. Bulletin I, No. 5, p. 247, February, 1898). "The observations recorded in this comnunication were made for the purpose of ascertaining additional facts relative to the variability of 'introduced species.'”

Littorina littorea is selected for study. First collected at Bathurst on the Gulf of St. Lawrence in 1855, the southward migration of the species is traced to New Haven (1880). 10,000 shells were collected from ten American, and 3,000 from three English localities for measurement and weighing, the results being summarized as follows: "We may then conchude that the periwinkle, subjected to a new environment, and presumably emancipated from many of the restraining influences of natural selection, has become in any and all American localities :

"I and II, more variable in its stature. III, more variable in its course of growth. IV, more variable in weight. V, more variable in bulk. VI, more variable in limitations and boundaries of the color patterns.

" While presenting these extremes of variation, the American type of Littorina littorea, when compared with the European type, is more elongated, lighter in weight, more bulky, and the color markings are less pronounced." 
308. Gastrodonta andrewser (IV. G. B.). Mountains of North Carolina along the 'lemnessee boundary.

309. Gastromonta uultidentata (Binn.). Quebec and Ont. to Michigan, south to New York and Ohio.

310. Gastrodonta lamellidens Pils. Clingman's Dome, Great Smoky Mis.

Genus PRISTIL JMA Ancey, 18si.

311. Pristiloma lansingi (Bld.). Astoria, Oregon to Vancouver Island.

312. Pristilona stearisi (Bld.). Oregon, Washington, British Culumbia, Pt. Barrow, Alaska. (Hyalina aretica Lehnert, Science Record, June, 1884, is a synonym.).

\section{Family LIMACID屁.}

Genus LIMAX L.

313. Limax maxmus L. Seaports and principal cities of east and west coasts. New Braunfels, Texas.

314. Limax flaves L. Seaports and principal cities of the Atlantic seaboard, Boston to Charleston, S. C. (L. variegatus Drap. is the same).

Genus AGRIOLIMAX Möreh, 1 s6s.

315. Agriolmix agrestis (L.). Seaports of east and west coasts, often spreading well inland. There are many named colorforms.

316. Agriolinax Campestris (Binn.). Entire U.S. Varieties occiclentalis Coop., montanus and castaneus Ing., ingersolli IV. G. B., hyperboreus West, and a number of color-forms have been described.

317. Agriolmax hemphilli (W. G. 33.). Julian City, Cal.; San Tomas, Lower Cal. A color-variety pictus Ckll. is described.

\section{Genus AMALIA Moq., 1855.}

318. Amalia hewstoni (Coop.). Seattle, Wash. to San Diego Co., Cal. May be identical with the European A. gagates.

\section{Family ARIONID床.}

Subfamily Arioninæ Pilsbry.

Genus ARION Fér.

319. A lion hortensis Fér. Boston and New Bedford, Mass.; Poughkeepsie, N. Y.; Seattle, Washington. Introduced from Europe. 
Genus PROPHYSAON W. G. Binney.

320. Prophishon andersoni (Coop.). Middle California to Vancouver Island.

321. Propirsaon foliolatum (Gld.). Seattle, Olympia, and Puget Sound region, Washington.

322. Prophisa con ceruleum Ckll. Seattle and Olympia, Washington.

323. Propilysan fasciatun Ckll. Old Mission, Idaho: Chehalis and Seattle, Washington.

Genus ANADENULUS Cockerell.

324. Anadenulus cockereldi (Hemph.). Cuyamanca Mits., San Diego Co., Cal.

\section{Subfamily Ariolimacinæ Pilsbry.}

(ienus HESPERARION Simroth.

325. Hesperarion niger (Coop.). Neighborhood of San Francisco Bay.

326. Hesperarion hemphilli (W. G. B.). Niles Station, Alameda Co., California.

Genus APHALLARION Pils. \& Van.

327. A pirallarion isuttoni Pils. \& Van. Oakland to Santa Cruz, Cal. (Ariolimax hecoxi Weth., undescrilied, is said to be the same).

(ienus ARIOLIMAX Mörch.

328. Ariolmax columbianus (Gla.). Middle Cal. to British Columbia. The hlack-blotched form maculatu. Ckll. occurs throughout the same range.

328a. Ariolimax columbinus stramineus Hemph. Santa Cruz Is]and, Cal.

329. Arrolmax californicus Cooper. San Mateo, Santa Clara and Santa Cruz counties, California.

Genu: HEMPHILLIA Binn. \& Bld.

330. Hemphilla glandulosa B. \& B. Puget Sound region to Astoria, Oregon.

331. Hemphilda camelus Pils. \& Van. Old Mission, Idaho. 
THE NAUTILUS.

(ienus BINNEYA Cooper.

332. Binneya notabilis Cooper. Sauta Barbara Island, Cal.; Guadelupe I., Lower Cal.

\section{Family PHILOMYCIDÆ.}

Genus PHILOMycus (Raf.) Fér.

333. Philomycus Carolinensis (Bosc). Canada to Florida, west to Iowa and Texas.

\section{Subgenus Pallifera Morse, 1864.}

334. Philomycus dorsa lis Binn. New England and New York. 335. Philomycus wetherbyi ( W . G. B.). Whitley Co., Ky. 336. Philomycus hemphrla (IV. G. B.). Mt. Mitchell, N. C.; Lula, Hall Co., Ga.

337. Philomycus Pennsy uvanicus Pils. Mountains of southern Pennsylvania.

\section{Family ENDODONTID无 Pilsbry.}

\section{Subfamily Endodontinæ Pils.}

Genus PYRAMIDULA Fitzinger, 1833.

\section{Subgenus Patula Held, 1537.}

338. Pyramidula alternata (Say). Quebec and Ontario to Minnesota, south to Comal Co., Texas.

Forms fergusoni Bld, and carinata auct. are distinguishable.

338a. Pyramidula alternata mordax (Shuttl.). West Virginia, East Tennessee.

339. Pyramidula cumberlandiana (Lea). Marion and Franklin counties, Tenn.; Jackson Co., Ala.; n.-w. Georgia.

340. Pyramidula solitaria (Say). Ohio and central Mississippi Valleys, south to Arkansas; Northern Idaho, Eastern Oregon. The IVestern form has been called var. occidentalis v. Martens, but it has only slight differential characters.

340a. Pyramidula solitaria limitaris Dawson. Waterton Lake, Rocky Mts., British America.

341. Pyramidula strigosa (Gld.). Rocky Mt. region and Great Basin, from State of Sonora, Mexico, north to Wyoming and Washington.

341a. Pyramidula strigosa idahoensis (Newc.). Idaho, between Idaho City and Coeur d'Alène.

341 b. Pyramidula strigosa newcomibi (Hemph.). North of Ogden, Utah. Form wasatchensis Hemph., near Ogden. 
341c. Pyramidula strigosa binneyi (Hemph.). Box Elder Co., Utah. Forms cooperi, multicostata, castanea, albofasciata and buttoni Hemph., same locality. Form gouldi Hemph., banks of Bear River, north of Brigham City, Utah.

341d. Pyranidula strigosa (Gld.) typical. Spokane, Washington. Var. parma Hemphill is a synonym.

341e. Pyramidula strigosa jugalis (Hemph.). Salmon River, Idaho. Form intersum Hemph., same locality.

341f. Prramidula strigosa subcarinata (Hemph.). Rathdrum, Idaho. Includes forms subcarinata, bicolor, lactea and picta Hemph.

341g. Pyramidula strigosa cooperi (IV. G. B.). Colorado, etc. Form globulosa Ckll., Summit Co.. trifasciata Ckll., Mesa Co., confluens Ckll., Custer, Garfield and Mesa Cos., elerata Ckll., Delta Co., major Ckli., Mesa Co., minor Ckll. near Egeria, Routt Co., all Colorado.

341h. Prramidula strigosa iowexsis Pils. Loess at Iowa City, Iowa (extinct).

341i. Pyramidula strigosa concentrata Dall. Summits of the Hachita Grande and Huachuca Mts., New Mexico and Arizona.

341j. Prramidula strigosa haydeni (Gabb). Utah. Form hemphilli Newc., Arizona, Nevada, Idaho, Utah and Colorado; form gabbiana Hemph., Near Salt Lake City ; form brnneri Ancey (oquirrhensis Hemph.), Oquirrh Mts., Utab ; form hybrida Hemph., near Logan, Utah.

\section{Subgentis Gonyodiscus Fitz.}

342. Prranidula perspectiva (Say). Minnesota to Texas, east to the Atlantic, but wanting from the Middle States east of the Alleghenies, and fron New England, Canada.

343. Pyramidula bryanti (Harper). Mitchell Co., N. C.

344. Pyramidua striatella (Anth.). Ontario to Winnepeg, Manitoba, Montana and Vancouver Id., south to New Mexico and Arizona. Kern River region, Cal.

344a. Pyramidula striatella catskilitensis Pils. Tannersville valley, Catskill Mits.

344b. Pyramidula striatella cronkhitei (Newc.). Klamath valley, Oregon. Nevada and California. 
Subgenus Planogyra Morse, 1864.

345. Pyramidula asteriscus (Morse). Quebec, Ont. and Maine (to Vancouver Island?).

\section{Genus HELICODISCUS Morse, 1864.}

346. Heliconiscus lineatus (Say). Ontario and Quebec to Florida, west to Rio Chama and White Oaks, New Mexico.

347. Helicodiscus fimbriatrs Wetherby. Tellico Plains, Tenn. A variety is reported from Indian Territory.

\section{Subfamily Punctinæ ( Tel Polyplacognatha). Genus PUNCTUM Morie.}

348. Punctum Prgmeum (Drap.). Quebec, Manitoba and northern States; Texas; California, Vancouver Id.

349. Punctum randolphi (Dal!). Seattle, Washington.

350. Punctum conspectum (Bld.). Middle California to Vancouver Id. and Sitka.

350a. Punctum conspectum pasanenat Pils. Pasadena, California.

351. Punctum clapp Pilsbry. Seattle and Tacoma, Washington ; Salem, Oregon.

352. Punctum californicum Pilsbry. Fish Camp, Fresno Co. Cal.

(ienus SPHYRADIUM ('harp.

353. Sphyradium edentelum (Drap.). Ontario to Vancouver Id. Vertigo simplex Gld. A longer cylindrical form, alticola Ingersoll, occurs in the Rocky Mts., Colorado, etc., and Mississippi valley Loess.

\section{(Superfamily ELASMOGNATHA.)}

Family SUCCINEID黁.

Genu: SUCCINEA Drap.

\section{(Amphibince)}

(The species of this section are variable and extremely difficult to define from the shells alone, and the soft anatony is as yet practically unknown).

354. Succinea saldeana Pfr. New Orleans and Alexandria, La.; Gloucester, N. J.

355. Succinea effusa "Shutt." Pfr. Florida. 
356. Succinea sillimaxi Bld. Nevada, California.

357. Succinea higginsr Bld. Put-in-Bay, Lake Erie.

358. Succinea retusa Lea. Canada to Montana, southward to Georgia. Includes S. ovalis Gld. not Say, S. forsheyi Lea, S. wilsoni Lea, S. calumetensis Calkins, S. peoriensis Wolf.

358a. Succinea retusa magister Pils. Mississippi valley from Tennessee to Minnesota: Michigan.

358 b. Succinea retusa decampi Tryon. Michigan. 359. Succinea nuttalliana Lea. Washington to California. 360. Succinea haydeni W. G. Binn. Nebraska to Utah. A form minor W. G. B. is recorded fronı Great Slave Lake. 361. Succinea hawkinsi Baird. Lake Osoyoos, B. C.

\section{(Neritostomce.)}

362. Succinea obliqua Say. Canadi to Montana, south to Nebraska, Arkansas and Georgia.

362a. Succinea obliqua totteniana Lea. Canada to Middle States.

\section{(Campestres.)}

363. Succinea Campestris Say. Georgia and Florida. S. inflata Lea is a synonym.

363a. Succinea Campestris unicolor Tryon. New Orleans, La.

364. Succinea luteola Gld. Texas; western Florila to the Keys.

365. Succinea coxcordilis Gld. Lake Concordia, Texas.

366. Succinea grosvenorit Lea. Louisiana, Mississippi and Texas north through Kansas and Nebraska to Great Slave Lake; Colorado, Montana and Utah. Synonyms are S. lineatu Binn. not DeKay, mooresiana Lea, greeri Tryon. Forms elonguta (Kremmling, Colo.) and rufescens Ckll. (Lee Co., Texas) are describer.

\section{(Lucence)}

367. Succixea arara Say. Canada to Georgia, west to Minn., Mont., CTah, Texas, California. Forms alba Ckll, Custer Co., Col. wardiuna Lea, vermetu Sily, compacta Ckll., major Binn. are describerl.

368. Scccrves aurea Leil. New York, Ohio. S. haleana Lea, Aleximaria, La., is probably synonymous.

369. Succinea verrilli Bland. Anticusti Island. 
370. Succinea oregonensis Liea. San Diego to Oregon; Utah ; Idaho.

370a. Succinea oregonensis gabbi Tryon. Utah, Wyoming, eastern Oregon.

371. Succinea rusticana Gld. Oregon, Cal., Nevada.

372. Succinea stretchiana Bld. Nevada, Idaho, Cal.

373. Succinea groenlandica Beck. Greeuland.

$$
\text { (Lautce.) }
$$

374. Succinea Chrysis Westerl. Port Clarence, St. Michaels and Kadiak, Alaska.

374a. Succinea chrysis aurelia Martens. Port Clarence, Alaska.

374b. Suucinea annexa Westerl. Port Clarence, Alaska. These three are probably mere variations of one species. They belong to an Asiatic group of the genus. S. chrysis occurs also on the Siberian side of the strait.

Suborder Teletremata Pilsbry.

\section{Family VAGINULID正.}

Genus VAGINULUS Fér.

375. Vaginulus floridanus Biun. Florida Keys, Charlotte Harbor and Punta Rassa.

Vaginulus

? Lobitos, Cal. (Stearns, as V.olivacea).

[Note.-The family Onchidiida belongs to this suborder, but as its species are not really terrestrial in habit, it is omitted from this list of land snails. The Auriculide, and especially Carychium, and Pomatiopsis lapidaria, might with greater propriety be included; but it has been thought best to omit them.].

Upon the Principles of Nomenclature and their Application to the Genera of Recent Moliusca, by J. Cosmo Melvill; being the Presidential Address delivered before the Conchological Society of Great Britain, September 19, 1896. This address embodies a very readable sketch of the history of nomenclature, from the pre-Linnean authors to the present time, with a list of molluscan gevera about the names of which difference of opiuion exists, observations upon the nomenclature of certain genera, and suggestions for the betterment in the future of the existing condition of the subject. 


\section{THE}

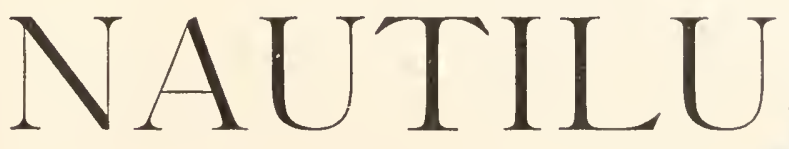

A MONTHLY

DEVOTED TO THE INTERESTS

OF CONCHOLOGISTS.

EDITUR :

H. A. Prlsery, Conservator Conchological Section, Academy of Natural Sciences, Philadelphia.

ASSOCIATE F.DITOR :

C. W. Johnson, Curator of the Wagner Free Institute of Science.

Vol. XI.

MAY, 1897.

No. 1

\section{CONTENTS :} Uvanilla Regina, A New Locality. By Robt. E. C. Stearns. • . 1 On a New Form of Polygyra from New Mexico. By W. H. Dall. . 2 Conchological Notes from Louisiana. By Lorraine S. Frierson. - 3 Contribution to a Knowledge of United States Unionide. By S.

Hart Wright.

List of Mollusks Collected in Malnonado Bay, Uruguay, by Dr.

Wm. H. Rush, U. S. N. By Henry A. Pilsbry. . . . . . 6

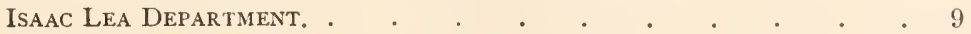

Fresh Water Shells in the Northeast of Maine. By Olof O. Ny-

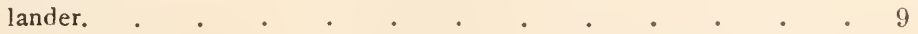

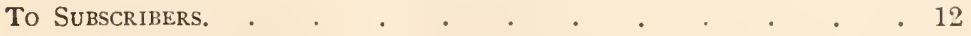

Published by

H. A. PILSBRY, Editor, Academy of Nat. Sciences, Philadelphia.

C. W. JOHNSON, Manager, Wagner Free Institute of Science, Philad'a.

Entered at Philadelphia Post-Office as second-class matter. 


\section{BACK VOLUMES OF THE NAUTILUS.}

Vol. IV. May, 1890 to April, 1891, . \$1.00

Vol. V. May, 1891 to A pril, 1892, . 1.00

Vol. VI. May, 1892 to A pril, 1893, . 1.00

Vol. VII. May, 1893 to A pril, 1894, . 1.00

Vol. ViII. May, 1894 to April, 1895. . 1.00

Vol. IX. May, 1895 to April, 1896. . 1.00

Of Vols. I and II, which were known as the "Conchologist's Exchange," and Vol. III of The Nautilus, we can furnish odd numbers only.

Extras of August and September number, (1895) containing an Index to the Conchologists' Exchange for binding with the latter, will be furnished at 10 cents per copy.

\section{ADV}

Advertisements will be inserted at the rate of $\$ 1.00$ per inch for each insertion in advance. Smaller space in proportion. A discount of 25 per cent. will be made on insertions of six months or longer. In order to have the paper out promptly, "copy" is put in the printer's hands on the 20th of each month.

Address, C. IV. JOHNSON,

WAGNER FREE INSTITUTE,

Philadelphia, Pa.

\section{EXCHANGES,}

The following space is to be given to exchanges. Notices not exceeding three lines, will be free to subscribers as long as our limit of space will allow.

For Exchange:--Planorbis nautileus Lin., P. aroostookensensis Pils. and other land and fresh water shells of Northern Maine. For land, fresh water and marine shells.

Olof O. Nylander, Caribou, Maine.

For Exchange:-Land and fresh water shells of southern Wis. for some from other localities. WANTED :-Unio tuberculatus opals, fine crystals, minerals, fossils or marine curios.

Mrs. E. C. W'iswall, Kenosha, Wis.

For Exchange:-Land, fresh water and marine shells, (many rare species offered) for species not in my collection. List first.

C. F. ANCEY, administrateur-adjoint, Dra-el Mizan, Algeria.

For Exchange:-A large number of minerals, fossils and shells. For named marine and fresh-water shells.

H. B. Derr, 6561 Michigan Ave., Chicago, Ill.

For Exchange:-About 70 species of Unios including many rare southern varieties. IV. S. STrode, M. D., Lewiston, Ill.

WAnted:- Say, Binney, 1858 Ed. Col. pl.-Am. Journ. Conch. Offered :-Lea's Obs. vol. V, Tryon's Strepomatide, Wood's Index Test. Lamarck's great work with hundreds of fine steel plates, 200-300 species shells, uncommonly fine minerals, Webster's unabr. Dict. 1884-almost new-etc., etc., etc. Write for list of other things offered. Dr. R. J. Kirkland, 85 Shelton St., Grand Rapids, Mich. 


\title{
The Natural Science Journal
}

\author{
A Monthly Publication Devoted \\ to the Natural Sciences.
}

Departments in Anthropology, Botany, Conchology, Geographics, Geology, Mineralogy and Ornithology, with other special features.

\section{Subscriptions ONE DOLLAR Per Year.}

\author{
AN EXCELLENT LOW PRICED ADVERTISING \\ MEDIUM.
}

Published by

\section{The Atlantic Scientific Bureau,} 1036 ACUSHNET AVENUE, NEW BEDFORD, MASS.

\section{"THE MUSEUM"}

A new Journal published on the 15 th of each month by Walter F. Webb, Albion, N. Y., Devoted to Natural Science, will contain, from time to time, fine bargains in shells and interesting articles in this line. SEND 10Cts. For Copy and my Catalogue.

\section{R. FRIEDLANDER \& SOHN,}

CARLSTRASSE 11,

BERLIN, N. W., GERMANY.

Reduced in price from $\$ 16.00$ to $\$ 10.00$, postage included.

Dr. C. A. WESTERLUND'S

Fauna der in der palæarktischen Rĕgion lebenden Binnen-Conchylien.

(The Palæarctic fresh water and terrestrial Mollusk Fauna.)

2 volumes (in 7 parts), with 2 supplements, 1886-90, 2,061 pages in Royal Octavo.

The chief modern work on Conchology.

Please apply for our CONCHOLOGICAL CATALOGUE (I06 pages with 3,925 titles), which will be sent free. 


\section{THE MANUAL OF CONCHOLOQY.}

Founded by the late Geo. W. Tryon, Jr., continued under the care of the Conchological Section, Academy of Natural Sciences of Philadelphia, by Henry A. Pilsbry, Conservator.

The Manual of Conchology is a fully illustrated monography of recent mollusks.

Issued in octavo form, in quarterly parts. Each part comprises 64 (or more) pages of letterpress, and is to 20 plates.

Two series are 110 w in progress: the FIRST SERIEs, Marine Univalves, of which sixteen volumes have appeared, finishing the series as planned by its illustrious founder. A supplemental volume to this series will be issued this year, to contain some families not heretofore considered. Of the SFcond SERIEs, Terrestrial Molluscs, Ten Volumes have been published, completing Helix with index. A few copies of Vol. IX of this series, "Guide to the Study of Helices" will be sold separately at the regular subscription price. Separate copies of the Index, suitable for the purposes of a Catalogue or Check list can also be had at \$r.00 each.

The Monography of the Bulimi has been connenced in the tenth volume.

The illustrations of the Manual have received high connuendation, and are fully equal to the best figures of shells published.

Prices :-Plain (uncolored) edition $\$ 3.00$ per part. Colored edition $\$ 5.00$ per part. Fine edition (both colored and India-tinted plates) $\$ \$ .00$ per part.

Structural and Systematic Conchology, by GEO W. TRYoN, Jr.

A Completf Conchological Text Book of 1200 pages, 140 plates and over 3500 figures of Genera, Anatomy, etc. Three volumes bound in one. Cloth. Price $\$ 6.00$.

For further information or descriptive circular, with sample plates of Mauual, address :

S. RAYMOND ROBERTS, Treasurer, P. 0. Address, GLEN RIDGE, NEW JERSEY, U. S. A.

\section{"The Al American Naturalist."}

MANAGING EDITORS:

Prof. E. D. COPE, Philadelphia, Pa., and Dr. F. C. KENYON, Washington, D. C.

\section{ASSOCIATE EDITORS:}

DR. C. E. BESSEY, of The University of Nebraska, Lincoln, Neb.

DR. H. C. MERCER, of The University of Pennsylvania.

Prof. C. M. WEED, College of N. H., Hanover, N. H.

Prof. W. S. BAYLEY, of Colby University, Waterville, Me.

Prom. E. A. ANDREWS, of Johns Hopkins University, Baltimore, Md.

Prof, A. C. GILL, Cornell University, Ithaca, N. Y.

Prof. H. C. WARREN, Princeton University, Princeton, N. J.

ERWIN F. SMITH, Department of Agriculture, Washington, D. C. SAMPLE COPY, 15 CEN'TS.

\section{THE EDWARDS \& DOCKER CO.,}
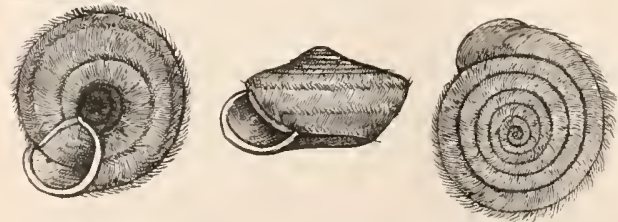

\section{HUGH FULTON,}

DEALER IN

\section{Recent Shells.}

About 10,000 species in stock. The finest stock of land-shells of any dealer. Only carefully authenticated and first-class specimens sent out. 


\section{THE}

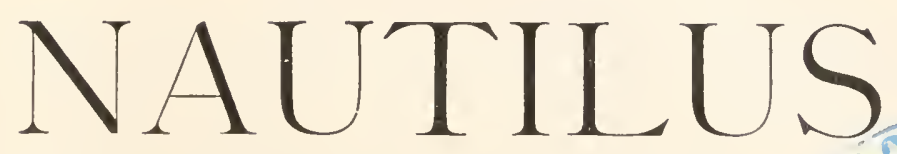

A MONTHLY

DEVOTED TO THE INTERESTS

OF CONCHOLOGISTS.

EDITUR :

H. A. Pilsbrv, Conservator Conchological Section, Academy of Natural Sciences, Philadelphia.

ASSOCIATE E.DITUR :

C. W. Johnson, Curator of the Wagner Free Institute of Science.

$\begin{array}{lll}\text { Vol. XI. JUNE, } 1897 . & \text { No. } 2\end{array}$

\section{CONTENTS :}

Heuriva Dysovi. By Charles T". Simpson. "20 "

Description of a New Species of Actaeon from the Quarternary

Bluffs of Spanish Bight, San Diego, California. By Robert E.

C. Stearns. . . . . . . . . 14

Notes on Agriolimax. By T. D. A. Cockerell. . . . . . 15

Description of Three New Eulote (Helices) from Central Asia.

By C. F. Ancey. . . . . . . . . . . 16

Notes on the Classification of the Unios. By Chas. T. Simpson. . 18

IsAac LeA DepartMent. . . . . . . . . . . 23

Published by

H. A. PILSBRY, Editor, Academy of Nat. Sciences, Philadelphia.

C. W. JOHNSON, Manager, Wagner Free Institute of Science, Philad'a.

Entered at Philadelphia Post-Office as second-class matter. 


\section{BACK VOLUMES OF THE NAUTILUS.}

Vol. IV. May, 1890 to April, 1891, . $\$ 1.00$

Vol. V. May, 1891 to A pril, 1892, . 1.00

Vol. VI. May, 1892 to A pril, 1893, . 1.00

Vol. VII. May, 1893 to April, J894, . 1.00

Vol. VIII. May, 1894 to April, 18yis. . 1.00

Vol. IX. May, 1895 to April, 1896. . 1.00

Vol. X. May, 1896 to April, 1897. . 1.00

Of Yols. I and II, which were known as the "Conchologist's Exchange," and Vol. III of The Nautilus, we can furnish odd numbers only.

Extras of August and September number, (1895) containing an Index to the Conchologists' Exchange for binding with the latter, will be furnished at 10 cents per copy.

\section{ADVRRTSREG RATHS。}

Advertisements will be inserted at the rate of $\$ 1.00$ per inch for each insertion in advance. Smaller space in proportion. A discount of 25 per cent. will be made on insertions of six months or longer. In order to have the paper out promptly, "copy" is put in the printer's hands on the 20th of each month.

Address, C. W. JOHNSON, WAGNER FreE INSTITUTE,

Philadelphia, Pa.

\section{EXCHANGES,}

The following space is to be given to exchanges. Notices not exceeding three lines, will be free to subscribers as long as our limit of space will allow.

For Exchange :--Planorbis nautileus Lin., P. aroostookensensis Pils. and other land and fresh water shells of Northern Maine. For land, fresh water and marine shells.

Olof O. Nylander, Caribou, Maine.

For Exchange:-Land and fresh water shells of southern Wis. for some from other localities. WA NTED :-Unio tuberculatus opals, fine crystals, minerals, fossils or marine curios.

Mrs. E. C. Wiswall, Kenosha, Wis.

For Excirange:-Land, fresh water and marine shells, (nany rare species offered) for species not in my collection. List first.

C. F. ANCEY, administrateur-adjoint, Dra-el Mizan, Algeria.

For Excilaxge:-A large number of minerals, fossils and shells. For named marine and fresh-water shells.

H. B. Derr, 6561 Michigan Ave., Chicago, Ill.

For Exchange:-About 70 species of Unios including many rare southern varieties. W. S. Strode, M. D., Lewiston, Ill.

Wanted:-Say, Binney, 1858 Ed. Col. pl--Am. Journ. Conch. Offered :-Lea's Obs. vol. V, Tryon's Strepomatide, Wood's Index Test. Lamarck's great work with hundreds of fine steel plates, 200-300 species shells, uncommonly fine minerals, Webster's unabr. Dict. 1884-almost new-etc., etc., etc. Write for list of other things offered.

Dr. R. J. KirkLand, 85 Shelton St., 


\title{
The Natural Science Journal
}

\author{
A Monthly Publication Devoted \\ to the Natural Sciences.
}

Departments in Anthropology, Botany, Concliology, Microscopy, Geology, Mineralogy, Ornithology, Oology, Physiology, and Hygiene, also an Exchange and Want column, with other Special Features.

\section{Subscriptions ONE DOLLAR Per Year.} AN EXCELLENT LOW PRICED ADVERTISING MEDIUM.

Published by

\section{The Atlantic Scientific Bureau,} 1036 ACUSHNET AVENUE, New Bedford, Mass.

\section{Bargains in Land and Marine Shells.}

Rare and Choice Specimens offered at the lowest prices. Satisfaction guaranteed or money refunded. Every specimen correctly classified. Send list of desiderata.

JA YES A. HARKINS, Atlantic City, N. J.

Shells, Marine Curios, \&c. $\begin{gathered}\text { I ann now ready to sup- } \\ \text { ply first-class stock at }\end{gathered}$ low prices and should you wish anything from this section, let ne hear from you. All inquiries will have a prompt reply.

J. H. HOLMES, DUNEDIN, FLA.

\section{R. FRIEDLANDER \& SOHN,}

\author{
CARLSTRASSE 11 ,
}

BERLIN, N. W., GERMANY.

Reduced in price from $\$ 16.00$ to $\$ 10.00$, postage included.

\section{Dr. C. A. WESTERLUND'S}

Fauna der in der palæarktischen Rĕgion lebenden Binnen-Conchylien.

(The Palearctic fresh water and terrestrial Mollusk Fauna.)

2 volumes (in 7 parts), with 2 supplements, 1886-90, 2,061 pages in Royal Octavo.

The chief modern work: on Conchology.

Please apply for our CONCHOLOGICAL CATALOGUE (106 pages with 3,925 titles), which will be sent free. 


\title{
THE MANUAL OF CONCHOLOQY.
}

Founded by the late Geo. W. 'Tryon, Jr., continued under the care of the Conchological Section, Academy of Natural Sciences of Philadelphia, by Henry A. Pilsbry, Conservator.

The Manual of Conchology is a fully illustrated monography of recent mollusks.

Issued in octavo form, in quarterly parts. Each part comprises 64 (or more) pages of letterpress, and $\mathrm{I}_{5}$ to 20 plates.

Two series are now in progress: the FIRst SERIES, Marine Univalves, of which sixteen volumes have appeared, finishing the series as planned by its illustrious founder. A supplemental volume to this series will be issued this year, to contain some families not heretofore considered. Of the SFcond SERIEs, Terrestrial Molluscs, Ten Volumes have been published, completing Helix with index. A few copies of Vol. IX of this series, "Guide to the Study of Helices" will be sold separately at the regular subscription price. Separate copies of the Index, suitable for the purposes of a Catalogue or Check list can also be had at $\$$ r.o each.

The Monography of the Bulimi has been commenced in the tenth volume.

The illustrations of the Manual have received high commendation, and are fully equal to the best figures of shells publislied.

Prices :-Plain (uncolored) edition $\$ 3.00$ per part. Colored edition $\$ 5.00$ per part. Fine edition (both colored and India-tinted plates) $\$ 8.00$ per part.

Structural and Systematic Conchology, by GEO W. TRYON, Jr.

A Complete Conchological Text Book of 200 pages, 440 plates and over 3500 figures of Genera, Anatomy, etc. Three volumes bound in one. Cloth. Price $\$ 6.00$.

For further information or descriptive circular, with sample plates of Manual, addiess :

\section{S. RAYMOND ROBER'IS, 'Treasurer, P. 0. Address, GLEN RIDGE, NEW JERSEY, U. S. A.}

\section{"The American Naturalist."}

MANAGING EDITORS:

Prof. E. D. COPE, Philadelphia, Pa., and Dr. F. C. KENYON, Washington, D. C.

\section{ASSOCIATE EDITORS:}

DR. C. E. BESSEY, of The University of Nebraska, Lincoln, Neb.

DR. H. C. MERCER, of The University of Pennsylvania.

Prof. C M. WEED, College of N. H., Hanover, N. H.

Prof. W S. BAYLEY, of Colby University, Waterville, Me.

Ppor. E. A. ANDREWS, of Johns Hopkins University, Baltimore, Md.

Prof. A. C. GILL, Cornell University, Ithaca, N. Y.

Prof. H. C. IVARREN, Princeton University, Princeton, N. J.

ERWIN F. SMITH, Department of Agriculture, Washington, D. C.

SAMPLE COPY, 15 CENTS.

\section{THE EDWARDS \& DOCKER CO.,}
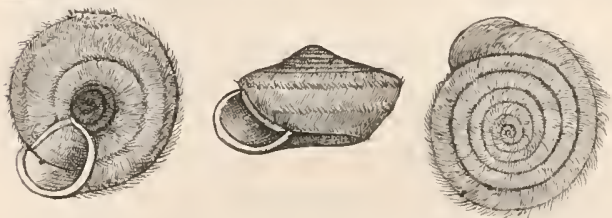

\section{HUGH FULTON,}

\author{
DEALER IN
}

\section{Recent Shells.}

About 10,000 species in stock. The finest stock of land-shells of any dealer. Only carefully authenticated and first-class specimens sent out.

Exchanges Made. Collections Purchased.

216 Kings Road, London, England. 


\section{THE}

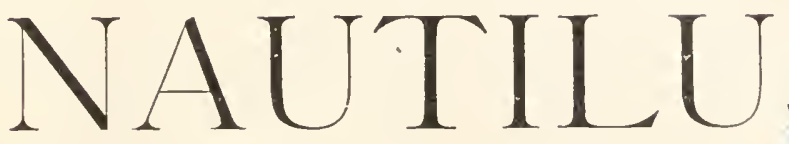

A MONTHLY

DEVOTED TO THE INTERESTS

OF CONCHOLOGISTS.

EDITUR :

H. A. Pilsbry, Conservator Conchological Section, Academy of Naturaı Sciences, Philadelphia.

ASSOCIATE FDITOR :

C. W. Johnson, Curator of the Wagner Free Institute of Science.

Vol. XI.

JULY, 1897.

No. 3

\section{CONTENTS :}

PAGE.

Synopsis of the Pinnide of the United States and West Indies.

By Wm. H. Dall. . . . . . . . . . . . 25 On Two So-Called “Bulimi" from the New Heerides. By C. F.

Ancey. . . . . . . . . . . . . . 26 A New Cancellaria from the Alabama Eocene. By T. H. Aldrich. 27 On a Collection of Mollusks from Grand Tower, Illinois. By

Frank C. Baker. . . . . . . . . . . 28 IsaAc Lea Department. . . . . . . . . . 30

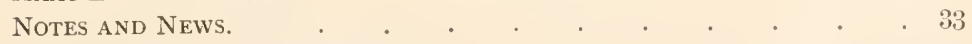
Recent Publications Received. . . . . . . . . . 34

Published by

H. A. PILSBRY, Editor, Academy of Nat. Sciences, Philadelphia.

C. W. JOHNSON, Manager, Wagner Free Institute of Science, Philad'a. Entered at Philadelphia Post-Office as second-class matter. 


\section{BACK VOLUMES OF THE NAUTILUS. \\ Vol. IV. May, 1890 to April, 1891, . $\$ 1.00$ \\ Vol. V. May, 1891 to A pril, 1892, . 1.00 \\ Vol. VI. May, 1892 to A pril, 1893 , . 1.00 \\ Vol. VII. May, 1893 to April, 1894, . 1.00 \\ Vol. VIII. May, 1894 to April, 1895. . 1.00 \\ Vol. IX. May, 1895 to April, 1896. . 1.00 \\ Vol. X. Nay, 1896 to April, 1897. . 1.00}

Of Vols. I and II, which were known as the "Conchologist's Exchange," and Tol. III of 'The Nautruus, we ean furnish odd numbers only.

Extras of August and September number, (1895) containing an Index to the Conchologists' Exchange for binding with the latter, will be furnished at 10 cents per copy.

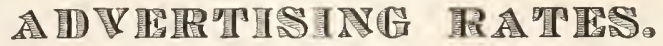

Advertisements will be inserted at the rate of $\$ 1.00$ per inch for each insertion in advance. Smaller space in proportion. A discount of 25 per cent. will be made on insertions of six months or longer. In order to have the paper out promptly, "copy" is put in the printer's hands on the 20th of each month.

Address, C. W. JOHNSON, WAGNER FREE INSTITUTE,

Philadelphia, Pa.

\section{EXCHANGES,}

The following space is to be given to exchanges. Notices not exceeding three lines, will be free to subscribers as long as our limit of space will allow.

For Exchange:--Planorbis nautileus Lin., P. aroostookensensis Pils. and other land and fresh water shells of Northern Maine. For land, fresh water and marine shells.

Olof O. Nylander, Caribou, Maine.

For Exchange:-Land and fresh water shells of southern Wis. for some from other localities. IT AXTED :- Unio tuberculatus opals, fine crystals, minerals, fossils or marine curios.

Mrs. E. C. Wiswall, Kenosha, Wis.

For Exchange:-Land, fresh water and marine shells, (many rare species offered) for species not in my collection. List first.

C. F. Ancer, administrateur-adjoint, Dra-el Mizan, Algeria.

For Exchange:-About 70 species of Unios including many rare southern varieties. IV. S. STrode, M. D., Lewiston, Ill.

WANTED:-North American Linnceidee in sets from various localities. OfFered :-Marine shells from Florida and land and fresh water shells from Chicago. Frank C. BAKER,

Academy of Sciences, Lincoln Park, Chicago, Ill.

Wanted:-No. 7, Vol. III, of The Nautilus. Offrered :Other Conchological papers.

M. M. Schepuans, Rhoon near Rotterdam, Netherland. 


\title{
The Natural Science Journal
}

\author{
A Monthly Publication Devoted \\ to the Natural Sciences.
}

Departments in Anthropology, Botany, Conchology, Microscopy, Geology, Mineralogy, Ornithology, Oology, Physiology, and Hygiene, also an Excliange and Want column, with other Special Features.

\section{Subscriptions ONE DOLLAR Per Year.}

AN EXCELLENT LOW PRICED ADVERTISING MEDIUM.

Published by

\section{The Atlantic Scientific Bureau,} 1036 ACUSHNET AVENUE, New Bedford, Mass.

\section{Bargains in Land and Marine Shells.}

Rare and Choice Specimens offered at the lowest prices. Satisfaction guaranteed or money refunded. Every specimen correctly classified. Seud list of desiderata.

JAMES A. HARKINS, Atlantic City, N. J.

Shells, Marine Curios, \&c. I am now ready to suplow prices and should you wish anything from this first-class stock at from you. All inquiries will have a prompt reply.

J. H. HOLMES, DUNEDIN, FLA.

\section{R. FRIEDLANDER \& SOHN, \\ CARLSTRASSE 11, \\ BERLIN, N. W., GERMANY.}

Reduced in price from $\$ 16.00$ to $\$ 10.00$, postage included.

Dr. C. A. WESTERLUND'S

Fauna der in der palæarktischen Rĕgion lebenden Bimnen-Conchylien.

(The Palæarctic fresh water and terrestrial Mollusk Fauna.)

2 volumes (in 7 parts), with 2 supplements, $1886-90,2,061$ pages in Royal Octavo.

The chief modern work on Conchology.

Please apply for our CONCHOLOGICAL CATALOGUE (I06 pages with 3,925 titles), which will be sent free. 


\section{THE MANUAL OF CONCHOLOQY.}

Founded by the late Geo. W. Tryon, Jr;, continued under tlie care of the Conchological Section, Academy of Natural Sciences of Philadelphia, by Henry A. Pilsbry, Conservator.

The Manual of Conchology is a fully illustrated monography of recent mollusks.

Issued in octavo form, in quarterly parts. Each part comprises 64 (or more), pages of letterpress, and I $_{5}$ to 20 plates.

Two series are now in progress: the FIRST SERIES, Marine Univalves, of which sixteen volumes have appeared, finishing the series as planned by its illustrious founder. A supplemental volume to this series will be issued this year, to contain some families not heretofore considered. Of the SFcond SERIEs, Terrestria Molluscs, Ten Volumes have been published, completing Helix with index. A few copies of Vol. IX of this series, "Guide to the Study of Helices" will be sold separately at the regular subscription price. Separate copies of the Index, suitable for the purposes of a Catalogue or Check list can also be had at $\$ \mathrm{r} .00 \mathrm{each}$.

The Monography of the Bulimi has been commenced in the tenth volume.

The illustrations of the Manual have received high commendation, and are fully equal to the best figures of shells published.

Prices :-Plain (uncolored) edition $\$ 3.00$ per part. Colored edition $\$ 5.00$ per part. Fine edition (both colored and India-tinted plates) $\$ 8.00$ per part.

Structural and Systematic Conchology, by GEO W. TRYoN, Jr.

A Complete Conchological Text Book of 1200 pages, $x_{40}$ plates and over 3500 figures of Genera, Anatomy, etc. Three volumes bound in one Cloth. Price $\$ 6.00$.

For further information or descriptive circular, with sample plates of Manual, address :

S. RAYMOND ROBER'TS, Treasurer, P. 0. Address, GLEN RIDGE, NEW JERSEY, U. S. A.

\section{"The Al American Naturalist."

MANAGING EDITORS:

Prof. E. D. COPE, Philadelphia, Pa., and Dr. F. C. KENYON, Washington, D. C.

\section{ASSOCIATE EDITORS:}

Dr. C. E. BESSEY, of The University of Nebraska, Lincoln, Neb.

Dr. H. C. MERCER, of The University of Pennsylvania.

Prof. C M. WEED, College of N. H., Hanover, N. H.

Prof. W S BAYLEY, of Colby University, Waterville, Me.

Pıop. E. A. ANDREWS, of Johns Hopkins University, Baltimore, Md.

Prof. A. C. G1LL, Cornell University, Ithaca, N. Y.

Prof. H. C. IVARREN, Princeton University, Princeton, N. J.

ERIVIN F. SMlTH, Department of Agriculure, Washington, D. C.

SAMPLE COPY, 15 CENTS.

\section{THE EDWARDS \& DOCKER CO.,}

\section{8-5:20 MINAR ST.}

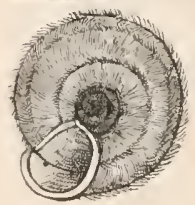

IPIIII,A D EIAI'II IA, U. S. A.
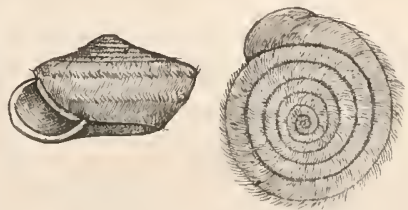

\section{HUGH FULTON,}

DEALER IN

\section{Recent Shells.}

Abont 10,000 species in stock. The finest stock of land-shells of any

- dealer. Unly carefully authenticated and first-class specimens sent out.

Exchanges Made.

Collections Purchased.

216 Kings Road, London, England. 


\section{THE}

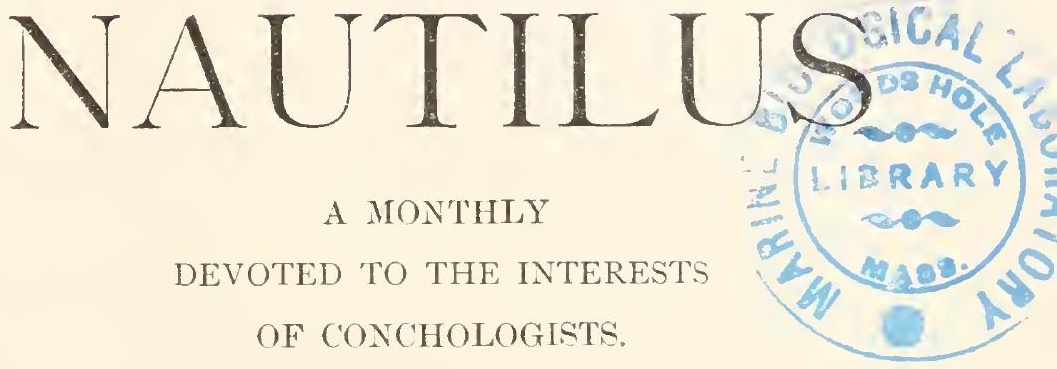

EDITUR:

H. A. Prlsbry, Conservator Conchological Section, Academy of Naturaı Sciences, Philadelphia.

ASSOCIATE F.DITOR :

C. W. Johnson, Curator of the Wagner Free Institute of Science.

Vol. XI. AUGUST, $1897 . \quad$ No. 4

\section{CONTENTS:}

PAGE,

Notes on landshells from the Malay Peninsula. By IV. H. Dall • 37 ON a New Holospira from Texas. By W. H. Dall. . . . . 38 Quarter-D:CKS ANd Jingles. By Robert E. C. Stearns. . . . . . 3s New Unios. By Berlin A. Wright. • . . . . . . . 411 Melania Yokohamensis, N. Sp. By W. D. Hartman. . . . . . 41 IsaAC LeA Department. . . . . . . . . . . 41 Notes and News. . . . . . . . . . . . . . . 43 Recent Publications Received. . . . . . . . . . 4 A Classified Catalogue of American land Shells, with Localities.

By Henry A. Pilsbry. 45

Published by

H. A. PILSBRY, Editor, Academy of Nat. Sciences, Philadelphia.

C. W. JOHNSON, Manager, Wagner Free Institute of Science, Philad'a. Entered at Philadelphia Post-Office as second-class matter. 


\section{BACK VOLUMES OF THE NAUTILUS.}

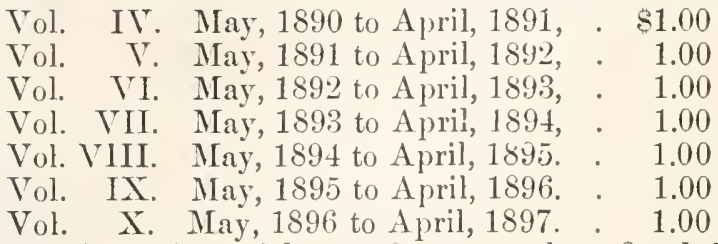

Of Vols. I and II, which were known as the "Conchologist's Exchange," and Tol. III of The Nautilus, we can furnish odd numbers only.

Extras of August and September number, (1895) containing an Index to the Conchologists' Exchange for binding with the latter, will be furnished at 10 cents per copy.

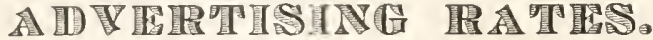

Advertisements will be inserted at the rate of $\$ 1.00$ per inch for each insertion in advance. Smaller space in proportion. A discount of 25 per cent. will be made on insertions of six months or longer. In order to have the paper out promptly, "copy" is put in the printer's hands on the 20th of each month.

Address, C. IV. JOHNSON,

IVAGNer FreE INSTITUTE, Philadelphia, $\mathrm{Pa}$.

\section{EXCHANGES,}

The following space is to be given to exchanges. Notices not exceeding three lines, will be free to subscribers as long as our limit of space will allow.

For Exchaxge :- Planorbis nautileus Lin., P. aroostookensensis Pils. and other land and fresh water shells of Northern Maine. For land, fresh water and marine shells.

Olof O. Nylander, Caribou, Maine.

For Exchange:-Land, fresh water and marine shells, (many rare species offered) for species not in my collection. List first.

C. F. Ancex, administrateur-adjoint, Dra-el Mizan, Algeria.

For Exchange:-About 70 species of Unios including many rare southern varieties. IV. S. STRODE, M. D., Lewiston, IH.

WANTED :-North American Limnceide in sets from various localities. OfFEred :- Marine shells from Florida and land and fresh water shells from Chicago.

Frank C. Baker,

Academy of Sciences, Lincoln Park, Chicago, Ill.

Wanted:-No. 7, Vol. III, of The Nautilus. Offered :Other Conchological papers.

MI. M. Schepmans, Rhoon near Rotterdam, Netherland.

Nautilus pompilius, decorticated, 8 inches in diameter to exchange for one in uatural condition.

T. VAn Hrning, Greenwood Park, Des Moines, Iowa. 


\section{EXCHANGES-Continued.}

Slugs Wanted.- We desire to obtain specimens of Prophysaon from any locality. Also Ariolimax (Hesperarion) niger and Hemphilli. The latter, described from Niles Station, Alameda Co., Cal., we have not yet seen. Also, and especially, Anadenus (Anadenulus) Cockerelii Hemphill, described from Cuyamaca Mts., San Diego Co., Cal. It is important that these forms be made known anatomically, and anyone who can supply any of them, or in fact any slugs, will receive due credit therefor in our publication, and, on application, we will send the first paper of our "Revision of N. A. Slugs." Slugs should be drowned in water and then preserved in alcohol diluted by about one-third its volume of water, or in a $3 \%$ solution of formalin. Alcohol is preferred, especially for small slugs. $-H$. A. Pilsbry, Academy Natural Sciences, Logan Square, Philadelphia, $P a$.

\section{Bargains in Land and Marine Shells.}

Rare and Choice Specimens offered at the lowest prices. Satisfaction guaranteed or money refunded. Every specimen correctly classified. Send list of desiderata.

JAIES A. HARKINS, Atlantic City, N. J.

\section{Shells, Marine Curios, \&c. I amn now ready to sup-} low prices and should you wish anything from this section, let me hear from you. All inquiries will have a prompt reply.

J. H. HOLMES, DUNEDIN, FLA.

\section{R. FRIEDLANDER \& SOHN,}

CARLSTRASSE 11,

BERLIN, N. W., GERMANY.

Reduced in price from $\$ 16.00$ to $\$ 10.00$, postage included.

Dr. C. A. WESTERLUND'S

Fauna der in der palrarktischen Région lebenden Binnen-Conchylien.

(The Palæarctic fresh water and terrestrial Mollusk Fauna.)

2 volumes (in 7 parts), with 2 supplements, 188 6 -90, 2,061 pages in Royal Octavo.

The chief modem uorl on Comehology.

Please apply for our CONCHOLOGICAL CATALOGUE (106 pages with 3,925 titles), which will be sent free. 


\section{THE MANUAL OF CONCHOLOQY.}

Founded by the late Geo. W. Tryon, Jr., continued under the care of the Con. chological Section, Academy of Natural Sciences of Philadelphia, by Henry A. Pilsbry, Collservator.

The Manual of Conchology is a fully illustrated monography of recent mollusks.

Issued in octavo form, in quarterly parts. Fach part comprises 64 (or more) pages of letterpress, and 15 to 20 plates.

Two series are now in progress: the FIRST SERIES, Marine Univalves, of which sixteen volumes have appeared, finishing the series as planned by its illustrious founder. A supplemental volume to this series will be issued this year, to contain some families not heretofore considered. Of the SFCoND SERIEs, Terrestrial Molluscs, Ten Volumes have been published, conpleting Helix with index. A few copies of Vol. IX of this series, "Guide to the Study of Helices" will be sold separately at the regular subscription price. Separate copies of the Index, suitable for the purposes of a Catalogue or Check list can also be had at \$r.oo each.

The Monography of the Bulini has been commenced in the tenth volume.

The illustrations of the Manual have received high commendation, and are fully equal to the best figures of shells published.

Prices:-Plain (uncolored) edition $\$ 3.00$ per part. Colored edition $\$ 5.00$ per part. Fine edition (both colored and India-tinted plates) $\$ \$ .00$ per part.

Structural and Systematic Conchology, by GEO W. TRYON, Jr.

A Completf CoNchological TExt Book of 1200 pages, r 40 plates and over 3500 figures of Genera, Anatomy, etc. Three volumes bound in one. Cloth. Price \$6.00.

For further information or descriptive circular, with sample plates of Manual, address :

\section{S. RAYIIOND ROBER'IS, 'Treasurer,}

P. O. Address, GLEN RIDGE, NEW JERSEY, U. S. A.

\section{6

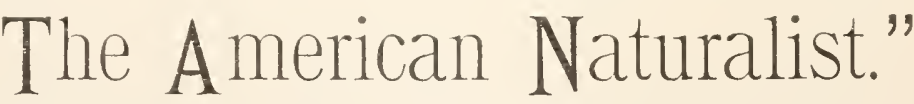

MANAGING EDITORS:

Prof. E. D. COPE, Philadelphia, Pa., and Dr. F. C. KENYON, Washington, D. C.

ASSOCIATE EDITORS:

Dr. C. E. BESSEY, of The University of Nebraska, Lincoln, Neb.

Dr. H. C. MERCER, of The University of Pennsylvania.

Prof. C M. WEED, College of N. H., Hanover, N. H.

Prof. W S BAYLEY, of Colby University, Waterville, Me.

Pyor. E. A. ANDREWS, of Johns Hopkins University, Baltimore, Md.

Prof. A. C. GILL. Cornell University, Ithaca, N. Y.

Prof. H. C. IVARREN, Princeton University, Princeton, N. J.

ERIVIN F. SMITH, Department of Agriculure, Washington, D. C.

SAMPLE COPY, 15 CENTS.

\section{THE EDWARDS \& DOCKER CO.,}

31S-5:20 MIXOIR ST.

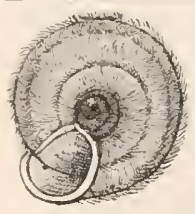

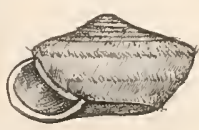

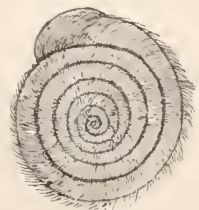

HUGH FULTON,

DEALER IN

\section{Recent Shells.}

About 10,001) species in stock. The finest stock of land-shells of any dealer. Only carefully authenticated and first-class specimens sent out. 


\section{THE}
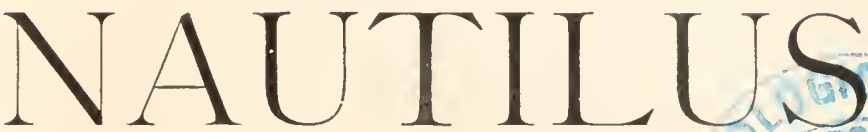

\section{A MONTHLY}

DEVOTED TO THE INTERESTS

OF CONCHOLOGISTS.

\section{EDITUR :}

H. A. Prlsbry, Conservator Conchological Section, Academy of Naturas Sciences, Philadelphia.

\section{ASSOCIATE FDITOR :}

C. W. Johnson, Curator of the Wagner Free Institute of Science.

Vol. XI.

SEPTEMBER, 1897.

No. 5

\section{CONTENTS :}

PAGE.

Bolinas, California; The Conchologists Paradise.

By Williard M. Wood. 49

Note on a Californian Heilix. By Henry A. Pilsbry. . . . 54

New Unios. By Berlin H. Wright. . . . . . . . 55

ISAac Lea Department.

A Classified Catalogue of American land Shells, with localities.

(Continued). By Henry A. Pilsbry. . . . . . . . 59

Published by

H. A. PILSBRY, Editor, Academy of Nat. Sciences, Philadelphia.

C. W. JOHNSON, Manager, Wagner Free Institute of Science, Philad'a.

Entered at Philadelphia Post-Office as second-class matter. 


\section{BACK VOLUMES OF THE NAUTILUS.}

Vol. IV. May, 1890 to April, 1891, . $\$ 1.00$

Vol. V. May, 1891 to A pril, 1842, . 1.00

Vol. VI. May, 1892 to A pril, 1893, . 1.00

Vol. VII. May, 1893 to April, 1894, . 1.00

Vol. VIII. May, 1894 to A pril, 18\% $2 . \quad 1.00$

Vol. IX. May, 1895 to April, 1896. . 1.00

Vol. X. May, 1896 to April, 1897. . 1.00

Of Vols. I and II, which were known as the "Conchologist's Exchange," and Tol. III of Tre Nautilus, we can furnish odd numbers only.

Extras of August and September number, (1895) containing an Index to the Conchologists' Exchange for binding with the latter, will be furnished at 10 cents per copy.

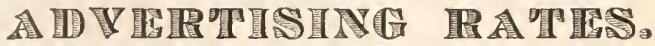

Advertisements will be inserted at the rate of $\$ 1.00$ per inch for each insertion in advance. Smaller space in proportion. A discount of 25 per cent. will be made on insertions of six months or longer. In order to have the paper out promptly, "copy" is put in the printer's hands on the 20th of each month.

Address, C. W. JOHNSON, WAGNER Free INSTITUTE, Philadelphia, $\mathrm{Pa}$.

\section{EXCHANGES,}

The following space is to be given to exchanges. Notices not exceeding three lines, will be free to subscribers as long as our limit of space will allow.

For Excinange:--Planorbis nautileus Lin., P. aroostookensensis Pils. and other land and fresh water shells of Northern Maine. For land, fresh water and marine shells.

Olof O. Nylander, Caribou, Maine.

For Exchange:-Land, fresh water and marine shells, (many rare species offered) for species not in my collection. List first.

C. F. Axcey, administrateur-adjoint, Dra-el Mizan, Algeria.

For Exchange:-About 70 species of Unios including many rare southern varieties. W. S. STRODE, M. D., Lewiston, Ill.

WANTED :-North American Limncide in sets from various localities. OFFERED :-Marine shells from Florida and land and fresh water shells from Chicago. Frank C. BAKER,

Academy of Sciences, Lincoln Park, Chicago, Ill.

Wanted:-No. 7, Vol. III, of The Nautilus. OfFered :Other Conchological papers.

MI. M. ScinepManx, Rhoon near Rotterdam, Netherland.

NaUtilus pompilius, decorticated, 8 inches in diameter to exchange for one in natural condition.

T. Van Hrning, Greenwood Park, Des Moines, Iowa. 


\section{EXCHANGES-Continued.}

Stugs Wranted.- We desire to obtain specimens of Irophigaon from any locality. Also Ariolimax (Hexperurion) niger and Hemphilli. The latter, described from Niles Station, Alameda Co., Cal., we have not yet seen. Also, and especially, Binneya notabilis Cooper. It is important that these forms be made known anatomically, and anyone who can supply any of them, or in fact any slings, will receive due credit therefor in our publication, and, on application, we will send the first paper of our "Revision of $\mathrm{N}$. A. Slugs." Slugs should be drowned in water and then preserved in alcohol diluted by about one-third its volume of water, or in a $3 \%$ solution of formalin. Alcohol is preferred, especially for small slugs.- $H$. A. Pilsbry, Academy Natural Sciences, Logan Square, Philadelphia, $P a$.

\section{Bargains in Land and Marine Shells.}

Rare and Choice Specimens offered at the lowest prices. Satisfaction guaranteed or money refunded. Every specimen correctly classified. Send list of desiderata.

JA ILE A. HARKINS. Atlantic City, N.J.

\section{Shells, Marine Curios, \&c. $\begin{gathered}\text { I am now ready to sup- } \\ \text { ply first-class stock at }\end{gathered}$} low prices and should you wish anything from this section, let me hear from you. All inquiries will have a prompt reply.

J. H. HOLMES, DUNEDIN, FLA.

\section{R. FRIEDLANDER \& SOHN,}

CAFLSTRASSF 11,

BERLIN, N. W., GERMANY.

Reduced in price from $\$ 16.00$ to $\$ 10.00$, postage included.

\section{Dr. C. A. WESTERLUND'S}

Fauna der in der palæarktischen Rĕgion lebendeı Binnen-Conchylien.

(The Palæarctic fresh water and terrestrial Mollusk Fauna.)

2 volumes (in 7 parts), with 2 supplements, 1886-90, 2,061 pages iil Royal Octavo.

The chief modern uorli on Conchology.

Please apply for our CONCHOLOGICAL CATALOGUE (106 pages with 3,925 titles), which will be sent free. 


\section{THE MANUAL OF CONCHOLOQY.}

Founded by the late Geo. W. Tryon, Jr., continued nnder the care of the Conchological Section, Acadeny of Tatural Sciences of Philadelphia, by Henry A. Pilsbry, Conservator.

The Manual of Conchology is a fully illustrated monography of recent mollusks.

Issued in octavo form, in quarterly parts. Fach part comprises 64 (or more) pages of letterpress, and I 5 to 20 plates.

Two series are now in progress: the FIRST SERIEs, Marine Univalves, of which sixteen volumes have appeared, finishing the series as planned by its illustrions founder. A supplemental volume to this series will be issued this year, to contain some families not heretofore considered. Of the SFCOND SERIEs, Terrestrial Molluscs, Ten Volumes have been published, completing Helix with index. A few copies of Vol. IX of this series, "Guide to the Study of Helices" will be sold separately at the regular subscription price. Separate copies of the Index, suitable for the purposes of a Catalogue or Check list can also be had at \$I.00 each.

The Monography of the Bulimi has been commenced in the tenth volume.

The illustrations of the Manual have received high commendation, and are fully equal to the best figures of shells published.

Prices:-Plain (uncolored) edition $\$ 3.00$ per part. Colored edition $\$ 5.00$ per part. Fine edition (both colored and India-tinted plates) $\$ 8.00$ per part.

Structural and Systematic Conchology, by GEO W. TRYON, Jr.

A Completf. Conchological Text Book of 1200 pages, 440 plates and over 3500 figures of Genera, Anatomy, etc. Three volumes bound in one. Cloth. Price $\$ 6.00$.

For further information or descriptive circular, with sample plates of Manual address :

\section{S. RAYUOND ROBER'TS, 'Treasurer,} P. 0. Address, GLEN RIDGE, NEW JERSEY, U. S. A.

\section{"The American Naturalist."}

MANAGING EDITORS:

Prof. E. D. COPE, Philadelphia, Pa, and Dr. F. C. KENYON, Washington, D. C.

\section{ASSOCIATE EDITORS:}

DR. C. E. BESSEY, of The University of Nebraska, Lincoln, Neb.

DR. H. C. MIERCER, of The University of Pennsylvania.

Prof, C M. WEED, College of N. H., Hanover, N. H.

Prof, IV S. BAYLEY of Colby University, Waterville, Me.

Puor. E. A. ANDREWS, of Johns Hopkins University, Baltimore, Md.

Prof. A. C. GILL, Cornell University, Ithaca, N. Y.

Prof. H. C. IVARREN, Princeton University, Princeton, N. J.

ERWIN F. SMITH, Department of Agriculture, Washington, D. C. SAMPLE COPY, 15 CFNTS.

\section{THE EDWARDS \& DOCKER CO.,}
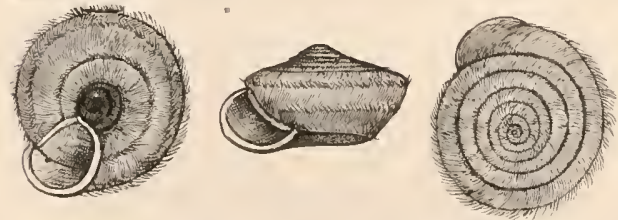

\section{HUGH FULTON,}

\author{
DEALER IN
}

\section{Recent Shells.}

About 10,001 species in stock. The finest stock of land-shells of any dealer. Only carefully authenticated and tirst-class specimens sent out. 


\section{THE}

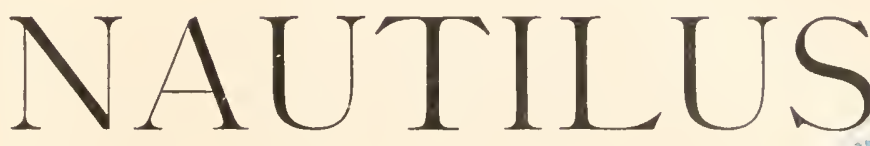

A MONTHLY

DEVOTED TO THE INTERESTS

OF CONCHOLOGISTS.

EDITUR :

H. A. Pilsbry, Conservator Conchological Section, Academy of Naturat Sciences, Philadelphia.

C. W. Johnson, Curator of the Wagner Free Institute of Science.

Vol. XI.

OCTOBER, 1897.

No. 6

\section{CONTENTS :}

New Land Shells from Mexico and New Mexico. By W. H. Dall. . 61 On Two New Species of Amphidromus. By C. F. Ancey. . . . 62 New Species of Tertiary Mollusca from Vancouver Island.

Editorial CORRESPONDENCE.

By John C. Merriam. 64

IsaAc Lea Departhent. . . . . . . . . . 67

General Notes.

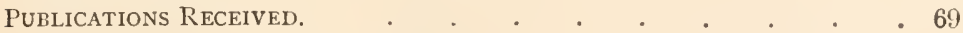

A Classified Catalogue of American land shelis, with localities.

(Continued). By Henry A. Pilsbry. . . . . . . 71

Published by

H. A. PILSBRY, Editor, Academy of Nat. Sciences, Philadelphia.

C. W. JOHNSON, Manager, Wagner Free Institute of Science, Philad'a.

Entered at Philadelphia Post-Office as second-class matter. 


\section{BACK VOLUMES OF THE NAUTILUS.}

Vol. IV. May, 1890 to April, 1891, . \$1.00

Vol. V. May, 1891 to A pril, 1892, . 1.00

Vol. VI. May, 1892 to A pril, 1893, . 1.00

Vol. VII. May, 1893 to April, 1894, . 1.00

Vol. VIII. May, 1894 to April, 1895. . 1.00

Vol. IX. May, 1895 to April, 1896. . 1.00

Vol. X. May, 1896 to April, 1897. . 1.00

Of Vols. I and II, which were known as the "Conchologist's Exchange," and Vol. III of The Nautilus, we can furnish odd numbers only.

Extras of August and September number, (1895) containing an Index to the Conchologists' Exchange for binding with the latter, will be furuished at 10 cents per copy.

\section{ADV W}

Advertisements will be inserted at the rate of $\$ 1.00$ per inch for each insertion in advance. Smaller space in proportion. A discount of 25 per cent. will be made on insertions of six months or longer. In order to have the paper out promptly, "copy" is put in the printer's hands on the 20th of each month.

Address, $\quad$ C. W. JOHNSON, WAGNER FREE INSTITUTE, Philadelphia, $\mathrm{Pa}$.

\section{EXCHANGES,}

The following space is to be given to exchanges. Notices not exceeding three lines, will be free to subscribers as long as our limit of space will allow.

For Exchange:--Planorbis nautileus Lin., P. aroostookensis Pils. and other land and fresh water shells of Northern Maine. For land, fresh water and marine shells.

Olof O. Nylander, Caribou, Maine.

For Exchange:-Land, fresh water and marine shells, (many rare species offered) for species not in my collection. List first.

C. F. Ancey, administrateur-adjoint, Dra-el Mizan, Algeria.

For Exchange:-About 70 species of Unios including many rare southern varieties. IV. S. STrode, M. D., Lewiston, Ill.

W ANTED :-North American Limnceide in sets from various localities. Offered :-Marine shells from Florida and land and fresh water shells from Chicago. Frank C. BAKER,

Academy of Sciences, Lincoln Park, Chicago, Ill.

Wanted:-No. 7, Vol. III, of The Nautilus. Offered :Other Conchological papers.

M. M. Schepilann, Rhoon near Rotterdam, Netherland.

For Exchange:-A few sets (12 to 15 variations) of Purpura lapillus as described in September Nautilus, from Pemaquid, Me. -Nowhere finer. F. C. Browne, Box 50, Framingham, Mass. 


\section{EXCHANGES-Continued.}

Slugs Wanted.- - We desire to obtain specimens of Prophysaon from any locality. Also Ariolimax (Hesperarion) niger and Hemphilli. The latter, described from Niles Station, Alameda Co., Cal., we have not yet seen. Also, and especially, Binneya notabilis Cooper. It is important that these forms be made known anatomically, and anyone who can supply any of them, or in fact any slugs, will receive due credit therefor in our publication, and, on application, we will send the first paper of our "Revision of $N$. A. Slugs." Slugs should be drowned in water and then preserved in alcohol diluted by about one-third its volume of water, or in a $3 \%$ solution of formalin. Alcohol is preferred, especially for small slugs.- $H$. A. Pilsbry, Academy Natural Sciences, Logan Sqnare, Philadelphia, $P a$.

\section{Shells, Marine Curios, \&c. I Im now ready to sup-} low prices and should you wish anything from this section, let me hear from you. All inquiries will have a prompt reply.

J. H. HOLMES, DUNEDIN, FLA.

\section{Books from the Press of The Journal Publishing Co.}

MERIDEN, CONN.

CONNECTICUT HISTORICAL SERIES.

History of Plymouth, Conn.

450 octavo pages, profusely illustrated. A valuable Historical Work. Cloth, $\$ 3.00$ post-paid. 3rd Edition.

History of Kent, Conn.

176 octavo pages, fully illustrated, of great value to geneologists. Cloth, $\$ 3.00$ post-paid.

Souvenir History of Bristol, Conn.

Quarto, 250 fine halftone illustrations. Paper, 50c. post-paid.

Souvenir History of Wallingford, Conn.

Quarto, finely illustrated. Paper, 35c. post-paid. 2nd Edition.

Souvenir History of Meriden, Conn.

Quarto, nearly 300 fine illustrations. Paper, 25c. post-paid. 3rd Edition.

Report of America's Relief Expedition to Asia Minor, by Miss Clara Barton, President American National Red Cross.

143 pages, fully illustrated. Paper, 30c.

THE JOURNAL PUBLISHING CO., 


\section{THE MANUAL OF CONCHOLOQY.}

Founded by the late Geo. W. Tryon, Jr., continued under the care of the Conchological Section, Academy of Natural Sciences of Philadelphia, by Henry A. Pilsbry, Conservator.

The Manual of Conchology is a fully illustrated monography of recent mollusks.

Issued in octavo form, in quarterly parts. Each part comprises 64 (or more) pages of letterpress, and $I_{5}$ to 20 plates.

Two series are $110 \mathrm{w}$ in progress: the FIRST SERIES, Marine Univalves, of which sixteen volumes have appeared, finishing the series as planned by its illustrious founder. A supplemental volume to this series will be issued this year, to contain some families not leretofore considered. Of the SFcond SERIEs, Terrestrial Molluscs, Ten Volumes have been published, completing Helix with index. A few copies of Vol. IX of this series, "Guide to the Study of Helices" will be sold separately at the regular subscription price. Separate copies of the Index, suitable for the purposes of a Catalogue or Check list can also be had at \$1.00 each.

The Monograply of the Bulimi has been conmenced in the tenth volume.

The illustrations of the Manual have received high commendation, and are fully equal to the best figures of shells published.

Prices :-Plain (uncolored) edition $\$ 3.00$ per part. Colored edition $\$ 5.00$ per part. Fine edition (both colored and India-tinted plates) $\$ 8.00$ per part.

Structural and Systematic Conchology, by GEO IV. TRYON, Jr.

A Complete Conchological Text Book of 1200 pages, I 40 plates and over 3500 figures of Genera, Anatomy, etc. Three volumes bound in one. Cloth. Price $\$ 6.00$.

For further information or descriptive circular, with sample plates of Manual address :

S. RAYMOND ROBERTS, Treasurer, P. 0. Address, GLEN RIDGE, NEW JERSEY, U. S. A.

\section{(6) \\ The American Naturalist."}

MANAGING EDITORS:

Prof. E. D. COPE, Philadelphia, Pa,, and Dr. F. C. KENYON, Washington, D. C.

\section{ASSOCIATE EDITORS:}

Dr. C. E. BESSEY, of The University of Nebraska, Lincoln, Neb.

DR. H. C. MERCER, of The University of Pennsylvania.

Prof, C. M. IVEED, College of N. H., Hanover, N. H.

Prof. W S. BAYLEY, of Colby University, Waterville, Me.

Pror. E. A. ANDREWS, of Johns Hopkins University, Baltimore, Md.

Prof. A. C. GILL, Cornell University, Ithaca, N. Y.

Prof. H. C. WARREN, Princeton University, Princeton, N. J.

ERWIN F. SMITH, Department of Agriculture, Washington, D. C. SAMPLE COPY, 15 CENTS.

\section{THE EDWARDS \& DOCKER CO.,}

$518-520$ MINOR S'T.

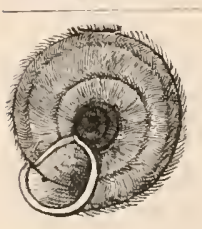

PII I I DEIAIIA, U. S.A.
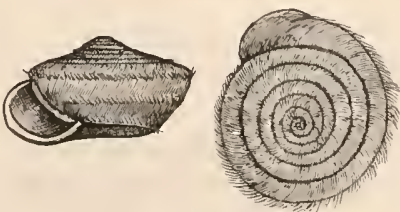

HUGH FULTON,

DEALER IN

Recent Shells.

About 10,000 species in stock. The finest stock of land-shells of any dealer. Only carefully authenticated and first-class specimens sent out. 


\section{THE}
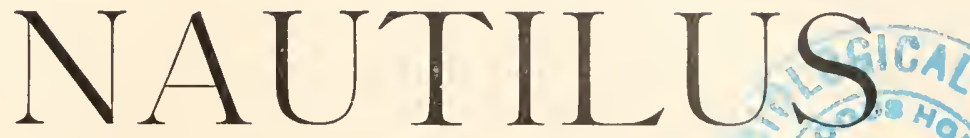

A MONTHLY

DEVOTED TO THE INTERESTS

OF CONCHOLOGISTS.

\section{EDITUR :}

H. A. PILSBRy, Conservator Conchological Section, Academy of Natura Sciences, Philadelphia.

ASSOCIATE FDITOR :

C. W. Johnson, Curator of the Wagner Free Institute of Science.

Vol. XI.

NOVEMBER, 1897.

No. 7

\section{CONTENTS :}

PAGE.

Neiv Species of Mexican Land Shells. By W. H. Dall. • . . 73 Description of a New VARiety of Land Shell from Idaho.

By Henry Hempihill. 74

Notes on Slugs. By T. D. A. Cockerell. . . . . . . 75

IsAac Lea Department. ․ . . . . . . . . 80

Notes And News. . $\quad . \quad$. $\quad . \quad$. . . . . . . . 81

A Classified Catalogue of American land Shells, with i.ocalities.

(Continued). By Henry A. Pilsbry. . . . . . . 83

\section{Published by}

H. A. PILSBRY, Editor, Academy of Nat. Sciences, Philadelphia.

C. W. JOHNSON, Manager, Wagner Free Institute of Science, Philad'a.

Entered at Philadelphia Post-Office as second-class matter. 


\section{BACK VOLUMES OF THE NAUTILUS.}

$\begin{array}{lrlr}\text { Vol. IV. May, } 1890 \text { to April, 1891, } & \$ 1.00 \\ \text { Vol. V. May, } 1891 \text { to April, 1892, } & 1.00 \\ \text { Vol. VI. May, } 1892 \text { to April, 1893, } & 1.00 \\ \text { Vol. VII. May, } 1893 \text { to April, 1894, } & 1.00 \\ \text { Vol. VIII. May, } 1894 \text { to April, 1895. } & 1.00 \\ \text { Vol. IX. May, } 1895 \text { to April, 1896. } & 1.00 \\ \text { Vol. X. May, } 1896 \text { to April, 1897. } & 1.00\end{array}$

Of Vols. I and II, which were known as the "Conchologist's Exchange," and Vol. III of The Nautruus, we can furnish odd numbers only.

Extras of August and September number, (1895) containing an Index to the Conchologists' Exchange for binding with the latter, will be furnished at 10 cents per copy.

\section{ADVERTISING MRTES。}

Advertisements will be inserted at the rate of $\$ 1.00$ per inch for each insertion in advance. Smaller space in proportion. A discount of 25 per cent. will be made on insertions of six months or longer. In order to have the paper out promptly, "copy" is put in the printer's hands on the 20th of each month.

Address, $\quad$ C. W. JOHNSON,

WAGNER FREE Institute,

Philadelphia, Pa.

\section{EXCHANGES,}

The following space is to be given to exchanges. Notices not exceeding three lines, will be free to subscribers as long as our limit of space will allow.

For Exchange:--Planorbis nautilens Lin., P. aroostookensis Pils, and other land and fresh water shells of Northern Maine. Fọr land, fresh water and marine shells.

Olof O. Nílander, Caribou, Maine.

For Exchaxge:-Land, fresh water and marine shells, (many rare species offered) for species not in my collection. List first.

C. F. Ancer, administrateur-adjoint, Dra-el Mizan, Algeria.

For Exchange:-About 70 species of Unios including many rare southern varieties. IV.S. STroDE, M. D., Lewiston, Ill.

W ANTED :-North American Limnceide in sets from various localities. OfFered :-Marine shells from Florida and land and fresh water shells from Chicago. FliANK C. BAKER,

Academy of Sciences, Lincoln Park, Chicago, Ill.

IVanted:-No. 7, Vol. III, of 'The Nautruus. Offered :Other Conchological papers.

M. M. Schermann, Rhoon near Rotterdam, Netherland.

For Exchange:-A few sets (12 to 15 variations) of Purpura lapillus as described in September Nautiuss, from Pemaquid, Me. -Nowhere finer. F. C. Browne, Box 50, Framingham, Mass. 
EXCHANGES-Continued.

Stugs Wanted.-We desire to obtain specimens of Prophysaon from any locality. Also Ariolimax (Hesperarion) niger and Hemphilli. The latter, described from Niles Station, Alameda Co., Cal., we have not yet seen. Also, and especially, Binneya notabilis Cooper. It is important that these forms be made known anatomically, and anyone who can supply any of them, or in fact any slugs, will receive due credit therefor in our publication, and, on application, we will send the first paper of our "Revision of N. A. Slugs." Slugs should be drowned in water and then preserved in alcohol diluted by about one-third its volume of water, or in a $3 \%$ solution of formalin. Alcohol is preferred, especially for small slugs.-H. A. Pilsbry, Academy Natural Sciences, Logan Square, Philadelphir, $P \ell$.

\section{Shells, Marine Curios, \&c. I Im now ready to sup-} low prices and should you wish anything from this section, let me hear from you. All inquiries will have a prompt reply.

J. H. HOLMES, DUNEDIN, FLA.

\section{Books from the Press of The Journal Publishing Co.}

MERIDEN, CONN.

\section{CONNECTICUT HISTORICAL SERIES.}

History of Plymouth, Conn.

450 octavo pages, profusely illustrated. A valuable Historical Work. Cloth, $\$ 3.00$ post-paid. 3rd Edition.

History of Kent, Conn.

176 octavo pages, fully illustrated, of great value to geneologists. Cloth, $\$ 3.00$ post-paid.

Souvenir History of Bristol, Conn.

Quarto, 250 fine halftone illustrations. Paper, 50c. post-paid.

Souvenir History of Wallingford, Conn.

Quarto, finely illustrated. Paper, 35c. post-paid. 2nd Edition.

Souvenir History of Meriden, Conn.

Quarto, nearly 300 fine illustrations. Paper, 25c. post-paid. 3 rd Edition.

Report of America's Relief Expedition to Asia Minor, by Miss Clara Barton, President American National Red Cross.

143 pages, fully illustrated. Paper, $30 \mathrm{c}$.

THE JOURNAL PUBLISHING CO. 


\section{THE MANUAL OF CONCHOLOGY.}

Founded by the late Geo. W. Tryon, Jr., continued under the care of the Conchological Section, Academy of Natural Sciences of Philadelphia, by Henry A. Pilsbry, Conservator.

The Manual of Conchology is a fully illustrated monography of recent mollusks.

Issued in octavo form, in quarterly parts. Each part comprises 64 (or more) pages of letterpress, and I5 to 20 plates.

Two seriesare $110 \mathrm{w}$ in progress: the FIRST SERIEs, Marine Univalves, of which sixteen volumes have appeared, finishing the series as planned by its illustrious founder. A supplenental volume to this series will be issued this year, to contain some families not heretofore considered. Of the SF.cond SERIEs, Terrestrial Molluscs, Ten Volumes have been published, completing Helix with index. A few copies of Vol. IX of this series, "Guide to the Study of Helices" will be sold separately at the regular subscription price. Separate copies of the Index, suitable for the purposes of a Catalogue or Check list can also be had at $\$ 1.00$ each.

The Monography of the Bulimi has been commenced in the tenth volume.

The illustrations of the Manual have received high commendation, and are fully equal to the best figures of shells published.

Prices:- Plain (uncolored) edition $\$ 3.00$ per part. Colored edition $\$ 5.00$ per part. Fine edition (both colored and India-tinted plates) $\$ 8.00$ per part.

Structural and Systematic Conchology, by GEO W. TRyoN, Jr.

A CoMplete Conchological. TEXT Book of 1200 pages, 140 plates and over 3500 figures of Genera, Anatomy, etc. Three volumes bound in one. Cloth. Price $\$ 6.00$.

For further information or descriptive circular, with sample plates of Manual address:

\section{S. RAYMOND ROBERTS, 'Treasurer, P. 0. Address, GLEN RIDGE, NEW JERSEY, U. S. A.}

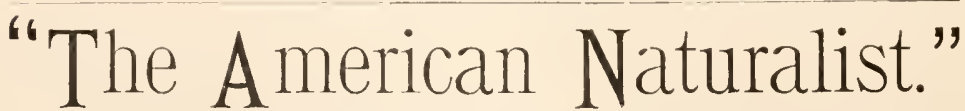

MANAGING EDITORS:

Prof. E. D. COPE, Philadelphia, Pa., and Dr. F. C. KENYON, Washington, D. C.

ASSOCIATE EDITORS:

DR. C. E. BESSEY, of The University of Nebraska, Lincoln, Neb.

DR. H. C. MERCER, of The University of Pennsylvania.

Prof. C. M. WEED, College of N. H., Hanover, N. H.

Prof. W S. BAYLEY, of Colby University, Waterville, Me.

puon. E. A. ANDREWS, of Johns Hopkins University, Baltimore, Md.

Prof, A. C. GILL, Cornell University, Ithaca, N. Y.

Prof. H. C. WARREN, Princeton University, Princeton, N. J.

ERWIN F. SMITH, Department of Agriculture, Washington, D. C.

SAMPLE COPI, 15 CENTS.

\section{THE EDWARDS \& DOCKER CO.,}




\section{THE}
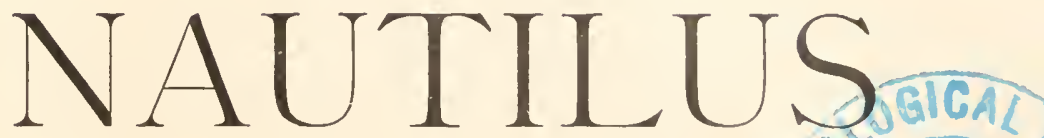

A MONTHLY

DEVOTED 'TO THE INTERESTS

OF CONCHOLOGISTS.

EDITUR :

H. A. Pılsery, Conservator Conchological Section, Academy of Naturaı Sciences, Philadelphia.

C. W. Johnson, Curator of the Wagner Free Institute of Science.

Vol. XI.

DECEMBER, 1897.

No. 8

\section{CONTENTS :}

New IVest American Shells. By W. H. Dall. . . . . . 85

Note on Two Species of Helicina. By C. F. Ancey. . . . . . 87

Oxychona Unmasked. By H. A. Pilsbry. . . . . . . . . 87

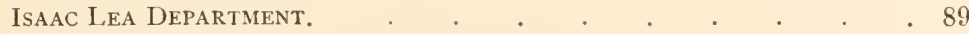

Notes AND News. . $\quad . \quad$. . . . . . . . . . . 90

A New Plicate Unio. By Berlin H. Wright. ․ . . . . . 91

Polygyra Ferrissi n. sp. By H. A. Pilsbry. . . . . . . 92

a Classified Catalogue of American Land Shells, with Localities. .

(Continued). By Henry A. Pilsbry. . . . . . . 93

\section{Published by}

H. A. PILSBRY, Editor, Academy of Nat. Sciences, Philadelphia.

C. IV. JOHNSON, Manager, Wagner Free Institute of Science, Philad'a.

Entered at Philadelphia Post-Office as second-class matter. 


\section{BACK VOLUMES OF THE NAUTILUS.}

Vol. IV. May, 1890 to April, 1891, . \$1.00

Vol. V. May, 1891 to A pril, 1892, . 1.00

Vol. VI. May, 1892 to A pril, 1893, . 1.00

Vol. VII. May, 1893 to April, 1894, . 1.00

Vol. V'III. May, 1894 to A pril, 1895̄. - 1.00

Vol. IX. May, 1895 to April, 1896. . 1.00

Vol. X. May, 1896 to April, 1897. . 1.00

Of Vols. I and II, which were known as the "Conchologist's Exchange," and Vol. III of The Nautilus, we can furnish odd numbers only.

Extras of August and September number, (1895) containing an Index to the Conchologists' Exchange for binding with the latter, will be furnished at 10 cents per copy.

\section{ADVRRTISHNG TRATHS.}

Advertisements will be inserted at the rate of $\$ 1.00$ per inch for each insertion in advance. Smaller space in proportion. A discount of 25 per cent. will be made on insertions of six months or longer. In order to have the paper out promptly, "copy" is put in the printer's hands on the 20th of each month.

Address,

C. W. JOHNSON, IVAGNER FREE INSTITUTE, Philadelphia, Pa.

\section{EXCHANGES,}

The following space is to be given to exchanges. Notices not exceeding three lines, will be free to subscribers as long as our limit of space will allow.

For Exchange:- Helix latiaxis, Lintere, Tayloriana; also large collection of land and marine (many rare). Desiderata new or rare Helices.

Miss Linter,

Arragon Close, Twickenham Middlesex, England.

For Exchange:-Land, fresh water and marine shells, (nany rare species offered) for species not in my collection. List first.

C. F. Ancer, administrateur-adjoint, Dra-el Mizan, Algeria.

For Exchange:-About 70 species of Unios including many rare southern varieties. W. S. STrode, M. D., Lewiston, Ill.

W ANTED :-North A merican Limnaide in sets from various localities. OfFeren :-Marine shells from Florida and land and fresh water shells from Chicago. Frank C. Baker,

Academy of Sciences, Lincoln Park, Chicago, Ill.

Wanted:-No. 7, Vol. III, of The Nautilus. Offered :Other Conchological papers.

MI. M. Schepunans, Rhoon near Rotterdam, Netherland. 
EXCHANGES-Continued.

For Exchange:-A few sets (12 to 15 variations) of Purpura lapillas as described in September Nautruus, from Pemaquid, Me. -Nowhere finer. $\quad$ F. C. Browne, Box 50, Framingham, Mass.

For Exchange:-A complete set of Random Notes on Natural History, for two of any of the following Trivias: sulcata, vitrea grando, maugeri, producta, pelucidula, formosa, napolina, pulla, affinis. John W Alton, 50 Scio St., Rochester, N. Y.

\title{
Shells, Marine Curios, \&c. I am now ready to sup-
} low prices and should you wish anything from this section, let me hear from you. All inquiries will have a prompt reply.

J. H. HOLMES, DUNEDIN, FLA.

\section{Books from the Press of The Journal Publishing Co.}

\author{
MERIDEN, CONN.
}

CONNECTICUT HISTORICAL SERIES.

History of Plymouth, Conn.

450 octavo pages, profusely illustrated. A valuable Histor-

ičal Work. Cloth, $\$ 3.00$ post-paid. 3rd Edition.

History of Kent, Conn.

176 octavo pages, fully illustrated, of great value to geneologists. Cloth, $\$ 3.00$ post-paid.

Souvenir History of Bristol, Conn.

Quarto, 250 fine halftone illustrations. Paper, 50c. post-paid.

Souvenir History of Wallingford, Conn.

Quarto, finely illustraterl. Paper, 35c. post-paid. 2nd Edition.

Souvenir History of Meriden, Conn.

Quarto, nearly 300 fine illustrations. Paper, 25c. post-paid. 3rd Edition.

Report of America's Relief Expedition to Asia Minor,

by $\mathbf{M}$ iss Clara Barton, President American National Red Cross.

143 pages, fully illustrated. Paper, 30c.

\section{THE JOURNAL PUBLISHING CO.,}

MERIDEN, CONN. 


\section{THE MANUAL OF CONCHOLOCY.}

Founded by the late Geo. W. 'Tryon, Jr., continued under the care of the Conchological Section, Academy of Natıral Sciences of Philadelphia, by Henry A. Pilsbry, Conservator.

The Manual of Conchology is a fully illustrated monography of recent mollusks.

Issued in octavo form, in quarterly parts. Each part comprises 64 (or more) pages of letterpress, and I5 to 20 plates.

Two series are now in progress: the FIRST SERIES, Marine Univalves, of which sixteen volumes have appeared, finishing the series as planned by its illustrious founder. A supplemental volume to this series will be issued this year, to contain some families not heretofore considered. Of the SFcond SERIEs, Terrestrial Molluscs, Ten Volumes have been published, completing Helix with index. A few copies of Vol. IX of this series, "Guide to the Study of Helices" will be sold separately at the regular subscription price. Separate copies of the Index, suitable for the purposes of a Catalogue or Check list can also be had at $\$ 1.00$ each.

The Monography of the Bulimi has been commenced in the tenth volume.

The illustrations of the Manual have received high commendation, and are fully equal to the best figures of shells published.

Prices :-Plain (uncolored) edition $\$ 3.00$ per part. Colored edition $\$ 5.00$ per part. Fine edition (both colored and India-tinted plates) $\$ 8.00$ per part.

Structural and Systematic Conchology, by GEO WV. 'TRYON, Jr.

A Completf, Conchological Text Book of 1200 pages, I 40 plates and over 3500 figures of Genera, Anatomy, etc. Three volumes bound in one. Cloth. Price $\$ 6.00$.

For further information or descriptive circular, with sample plates of Manua1 address :

\section{S. RAYMOND ROBER'S, 'Treasurer,} P. O. Address, GLEN RIDGE, NEW JERSEY, U. S. A.

\section{"The American Naturalist."}

MANAGING EDITORS:

Prof. E. D. COPE, Philadelphia, Pa, and Dr. F. C. KENYON, Washington, D. C.

ASSOCIATE EDITORS:

DR. C. E. BESSEY, of The University of Nebraska, Lincoln, Neb.

DR. H. C. MERCER, of The University of Pennsylvania.

Prof, C M. WEED, College of N. H., Hanover, N. H.

Prof. W S. BAYLEY, of Colby University, Waterville, Me.

Pıor. E. A. AN DREWS, of Johns Hopkins University, Baltimore, Md.

Prof. A. C. GILL, Cornell University, Ithaca, N. Y.

Prop. H. C. WARREN, Princeton University, Princeton, N. J.

ERWIN F. SMITH, Department of Agriculture, Washington, D. C. SAMPLE COPY, 15 CENTS.

\section{THE EDWARDS \& DOCKER CO.,}




\section{THE}

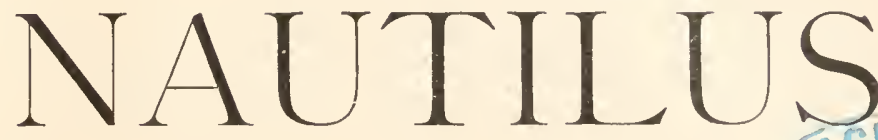

A MONTHLT

DEVO'TED TO THE INTERESTS

OF CONCHOLOGISTS.

EDITUR:

H. A. Pilsmry, Conservator Conchological Section, Academy of Naturat Sciences, Philadelphia.

ASSOCIATE FUITOR:

C. W. JoHnson, Curator of the Wagner Free Institute of Science.

Vol. XI.

JANUARY, 1898.

No. 9

\section{CONTENTS :}

Sume New Eocene Fossils from Alabama. By T. H. Aldrich. . 97

A Proposed Census of Michigan Mollusca. By Bryant Walker. . . 98 On A New Species of Vitrea from Maryland. By Wm. H. Dall. . 100 A Neiv Undulate Unio from Alabama. By Berlin H. Wright. • . 101 Modiola Plicatula lamarck-An Extinct Localty. By R. E. C. S. 102 ISAAC LeA Department. . . . . . . . . . 104

A Classified Catalogue of american land Shells, with Localities.

(Continued). By Henry A. Pilubry. . . . . . . 105

Published by

H. A. PILSBRY, Editor, Academy of Nat. sciences, Philadelphia.

C. W. JOHNSON, Manager, Wagner Free Institute of Science, Philad'a.

Entered at Philadelphia Post-Office as second-class matter. 


\section{BACK VOLUMES OF THE NAUTILUS.}

Vol. IV. May, 1890 to April, 1891, . $\$ 1.00$

Vol. V. May, 1891 to April, 1892, . 1.00

Vol. VI. May, 1892 to April, 1893, . 1.00

Vol. VII. May, 1893 to April, 1894, . 1.00

Vol. VIII. May, 1894 to A pril, 1895. . 1.00

Vol. IX. May, 1895 to April, 1896. . 1.00

Vol. X. May, 1896 to April, 1897. . 1.00

Of Vols. I and II, which were known as the "Conchologist's Exchange," and Vol. III of Trfe Nauticus, we can furnish odd numbers only.

Extras of August and September number, (1895) containing an Index to the Conchologists' Exchange for binding with the latter, will be furnished at 10 cents per copy.

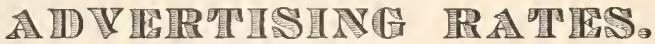

Advertisements will be inserted at the rate of $\$ 1.00$ per inch for each insertion in advance. Smaller space in proportion. A discount of 25 per cent. will be made on insertions of six months or longer. In order to have the paper out promptly, "copy" is put in the printer's hands on the 20th of each month.

Address,

C. IV. JOHNSON, WAGNER Free INSTITUTE, Philadelphia, Pa.

\section{EXCHANGES,}

The following space is to be given to exchanges. Notices not exceeding three lines, will be free to subscribers as long as our limit of space will allow.

For Exchange:- Helix latiaxis, Lintere, Tayloriana; also large collection of land and marine (many rare). Desiderata new or rare Helices. Miss Linter,

Arragon Close, Twickenham Middlesex, England.

For Exchange:-Land, fresh water and marine shells, (many rare species offered) for species not in my collection. List first.

C. F. Axcer, administrateur-adjoint, Dra-el Mizan, Algeria.

For Exchange:-About 70 species of Unios including many rare southern varieties. IV. S. STRode, M. D., Lewiston, Ill.

WANTED :-North American Limnoidoe in sets from various localities. OFFERED :-Marine shells from Florida and land and fresh water shells from Chicago. Frank C. BAKER,

Academy of Sciences, Lincoln Park, Chicago, Ill.

OfFERen:-Land, fresh-water and marine shells, many desirable species. Also a few Conchological books.

A. A. Hinkley, Du Bois, Ill. 
EXCHANGES-Continued.

For Exchange:-A few sets (12 to 15 variations) of Purpura lapillus as described in September Nautilus, from Pemaquid, Me. -Nowhere finer. F. C. Browne, Box 50, Framingham, Mass.

Wanted:-American slugs, British species offered in exchange. W. E. Colling F, Mason College, Birmingham, England.

Shells, Marine Curios, \&c. I am now ready to suplow prices and should you wish anything from this section, let me hear front you. All inquiries will have a prompt reply.

J. H. HOLMES, DUNEDIN, FLA.

\section{Books from the Press of The Journal Publishing Co. \\ MERIDEN, CONN.}

CONNECTICUT HISTORICAL SERIES.

History of Plymouth, Conn.

450 octavo pages, profusely illustrated. A valuable Historical Work. Cloth, \$3.00 post-paid. 3rd Edition.

History of Kent, Conn.

176 octavo pages, fully illustrated, of great value to geneologists. Cloth, \$3.00 post-paid.

Souvenir History of Bristol, Conn.

Quarto, 250 fine halftone illustrations. Paper, 50c. post-paid.

Souvenir History of Wallingford, Conn.

Quarto, finely illustrated. Paper, 35c. post-paid. 2nd Edition.

Souvenir History of Meriden, Conn.

Quarto, nearly 300 fine illustrations. Paper, 25c. post-paid. 3rd Edition.

Report of America's Relief Expedition to Asia Minor, by $\mathrm{M}$ iss Clara Barton, President American National Red Cross.

143 pages, fully illustrated. Paper, 30c.

THE JOURNAL PUBLISHING CO.,

MERIDEN, CONN. 


\section{THE MANUAL OF CONCHOLOQY.}

Founded by the late Geo. W. Tryou, Jr., continued under the care of the Conchological Section, Academy of Natural Sciences of Philadelphia, by Henry A. Pilsbry, Conservator.

The Manual of Conchology is a fully illustrated monography of recent mollusks.

Issued in octavo form, in quarterly parts. Each part comprises 64 (or more) pages of letterpress, and 15 to 20 plates.

Two series are now in progress: the FIRST SERIES, Marine Univalves, of which sixteen volumes have appeared, finishing the series as planned by its illustrious founder. A supplemental volume to this series will be issued this year, to contain some families not heretofore considered. Of the SFCOND SERiEs, Terrestrial Molluscs, Ten Volumes have been published, completing Helix with index. A few copies of Vol. IX of this series, "Guide to the Study of Helices" will be sold separately at the regular subscription price. Separate copies of the Index, suitable for the purposes of a Catalogue or Clieck list can also be had at \$I.00 each.

The Monography of the Bulimi has been commenced in the tenth volume.

The illustrations of the Manual have received high commendation, and are fully equal to the best figures of shells published.

Prices:-Plain (uncolored) edition $\$ 3.00$ per part. Colored edition $\$ 5.00$ per part. Fine edition (botli colored and India-tinted plates) $\$ 8.00$ per part.

Structural and Systematic Conchology, by GEO IV. TRYON, Jr.

A COMPLETF. CONCHOLOGICAL TEXT BOOK of 1200 pages, I 40 plates and over 3500 figures of Genera, Anatomy, etc. Three volumes bound in one Cloth. Price $\$ 6.00$.

For further information or descriptive circular, with sample plates of Manual address :

S. RA YMOND ROBERTS, T'Teasurer, P. 0. Address, GLEN RIDGE, NEW JERSEY, U. S. A.

\section{6

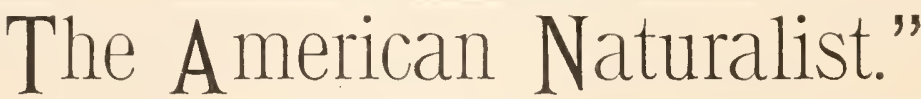

MANAGING EDITORS:

Prof. E. D. COPE, Philadelphia, Pa., and Dr. F. C. KENYON, Washington, D. C.

ASSOCIATE EDITORS:

Dr. C. E. BESSEY, of lhe University of Nebraska, Lincoln, Neb.

Prof. C M. WEED, College of N. H., Hanover, N. H.

Prof. W S BAYLEY, of Colby University, Waterville, Me.

Pيop. E. A. ANDREWS, of Johns Hopkins University, Baltimore, Md.

PROF. A. C. G1LL, Cornell University, Ithaca, N. Y.

Prof. H. C. WARREN, Princeton Universily, Princeton, N. J.

ERWIN F. SMITH, Department of Agriculture, Washington, D. C.

SAMPLE COPY, 15 CENTS.

THE EDWARDS \& DOCKER CO., 5IS-520 VINOH NT.

I'HII,A IDEI,IIIA, U. S. A.

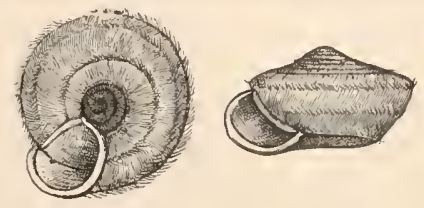

\section{CONCHOLOGY.}

G. B. SOWERBY and HUGH FULTON liave the pleasure of informing their clients that they have joined in partnership nniting their rich and extensive stocks of shells thereby bringing together an assortment unique in its vastness.

Amateurs and Museums eitler forming collections of Mollusca or desiring to add thereto, can by applying to the above, receive selections on approval at moderate prices.

Collections Purchased. Exchanges made for species not in stock. 


\section{THE}
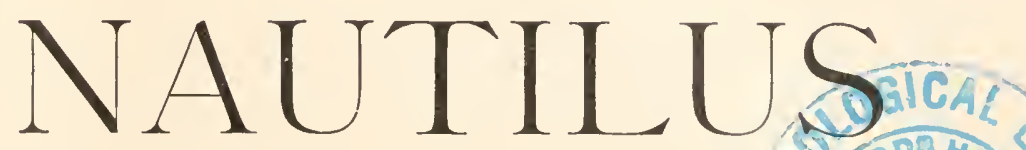

0040

A MONTHLY

DEVOTED TO THE INTERESTS

\section{OF CONCHOLOGISTS.}

\section{EDITUR :}

H. A. Pulsbry, Conservator Conchological Section, Academy of Naturaı Sciences, Philadelphia.

C. W. Johnson, Curator of the Wagner Free Institute of Science.

Vol. XI.

\section{CONTENTS :}

Unio (Lampsilis) Amphich Ænus, N. Sp. By Lorraine S. Frierson. Nutes on Quebec Pupid e and other Shells. By A. W. Hanham. 110 Description of a New Unio. By Berlin H. Wright. . . . . 111 New Pisidia. By Dr. V. Sterki. . . . . . . . . 112 Elwood Pleas. . . . . . . . . . . . . 114

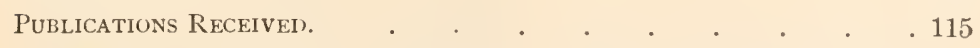
A Classified Catalogue of American land Shells, with Localities.

(Continued). By Henry A. Pilsbry.

\section{Published by}

H. A. PILSBRY, Editor, Academy of Nat. Sciences, Philadelphia.

C. W. JOHNSON, Manager, Wagner Free Institute of Science, Philad'a.

Entered at Philadelphia Post-Office as second-class matter. 


\section{A Fine Collection of Shelis For Sale.}

We have recently secured and have displayed in our establisliment, the Huckins Collection, formerly at Wat is for sale in large or small lots at very reasonable rates. Below we give a synopsis of some of the most important Genera:

Argonauta 3, Nautilus 3. Ianthina I, Murex 30, Trophon 8, Fulgur 3, Pleurotoma 6, Triton 20, Ranella 12, Nassa 27, Eburna 2, Purpura 20, Ricinula I I, Oliva 36, Olivella 5, Ancillaria 5, Fasciolaria 4, Latirus 6, Cymbium 4, Melo 4, Voluta 13, Marginella I5, $^{2}$ Mitra 37, Cylindra 3 , Turricula 6, Columbella 9, Harpa 6, Cassis 20 , Oniscia 5, Malea 3 , Dolium 7, Sycotrpus 3, Natica 3, Neverita 6, Ruma 5, Scalaria 3, Terebra 20. Couus 7o, Solarium 4, Strombus 36, Pterocera 8, Rostellaria I, Aporthais 2, Cypræa 9o, Trivia 13, Pustularia 7, Epona 4, Cerithium 24, Potamides 6, Littorina 15, Tectarius 5, Nerita 19, Neritıua 18, Anpullaria 4, Turbo 10, Astralium 5, Trochts 8, Calliostoma 6, Haliotis Io, Cantharus 9, Fissurella 9, Acmæa 7, Patella 18, Chiton 6, Bulla 9, Glandina 2, Xesta 5, Ryssota 3, Zonites 2r, Patula 7, Helix 125, Cochlostyla 11, Bulimus 1S, Bulimulus 7, Achatina 10, Partula 5, Achatinella 40, Strophia 17, Clausilia 8, Cyclotus 2, Cyclophorus 3, Cyclostonus 9, Helicina 7, Telliua 8, Donax 8, Chione 5, Callista 7, Cryptogramma 4, Tapes 6. Dosinia 3, Sphærium 7, Cardium 20, Tridacna 2, Hippopus I, Lncina 6, Solenya 2, Astarte 3 , Cardita 3, Unio 104, Margaritana 10, Anodonta 7, Avicula 4, Pinna 3, Arca 12, Yoldia 2, Pecten 15, Spondylus 4. and many others not enumerated, in all some 1600 species and about 15000 specimens.

We will send any of the above fine things on approval to reliable parties. The condition of the specimens are very fine, as they have been kept in dust-proof cases. We confidently believe they will please the most exacting collectors, and solicit your patronage, with an aim to please. This collection, with our fornier large stock, will enable us to furnish advanced collectors with many new and interesting things. We have many thousand fine duplicates that we will exchange for desirable Helix. Only the rarer species desired. Specially wish good lots of S. W. U. S. and showy Foreign species, notably West Indies forms.

Soliciting your correspondence,

\section{WEBB'S NATURAL SCIENCE ESTABLISHMENT, Walter F. Webb, Mgr., Albion, N. Y.}

\section{EXCHANGES,}

The following space is to be given to exchanges. Notices not exceeding three lines, will be free to subscribers as long as our limit of space will allow.

For Exchange:-Helix latiaxis, Lintera, Tayloriana; also large collection of land and marine (many rate). Desiderata new or rare Helices. Miss LINTER,

Arragon Close, Twickenham Middlesex, England.

For Exchange:-Land, fresh water and marine shells, (many rare species offered) for species not in my collection. List first.

C. F. Ancer, administrateur-adjoint, Dra-el Mizan, Algeria.

WAnted:-American slugs, British species offered in exchange. W. E. Collingr, Mason College, Birmingham, England.

IVANTED:-North American Limnceide in sets from various localities. OFFErED :-Marine shells from Florida and land and fresh water shells from Chicago. Frank C. BAkER, Academy of Sciences, Lincoln Park, Chicago, Ill.

OfFeren :-Land, fresh-water and marine shells, many desirable species. Also a few Conchological books.

A. A. Hinkley, Du Bois, Ill. 


\section{Ward's Natural Science Establishment,}

\section{8-28 College Ave., Rochester, N. Y.}

\section{A SCIENTIFIC EMPORIUM.}

Furnishes yearly to Collectors, Educational Institutions, and Museums throughout the world, many thousand dollars' worth of

INVERTEBRATES

(Shells, Corals, Sponges, Crustaceans, etc.)

SKINS AND SKELETONS OF VERTEBRATES,

MINERALS, ROCKS, FOSSILS.

ANATOMICAL PREPARATIONS, CASTS, MODELS, RELIEF MAPS,

ARCH样OGICAL AND ETHNOLOGICAL MATERIAL, HUMAN SKELETONS, Etc.

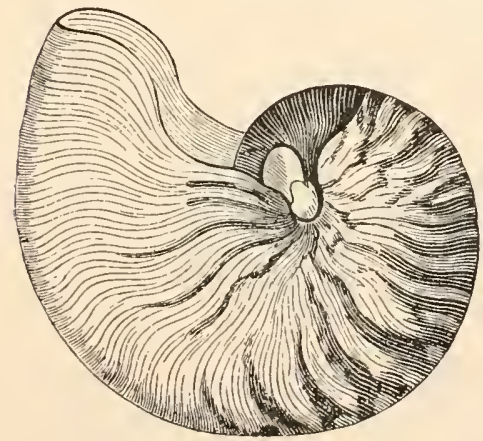

Our Australian Expedition of IS96 has augmented very considerably our extensive stock of shells, and has compelled the issuance of a new and enlarged edition of our illustrated "Catalogue of Mollusca," now in press. Watch this space for notice of its publication.

For information, circulars, etc., write to 


\section{THE MANUAL OF CONCHOLOQY.}

Founded by the late Geo. W. Tryon, Jr., continued under the care of the Conchological Section, Academy of Natural Sciences of Philadelphia, by Henry A. Pilsbry, Conservator.

The Manual of Conchology is a fully illustrated monography of recent mollusks.

Issued in octavo form, in quarterly parts. Each part comprises 64 (or more) pages of letterpress, and is to 20 plates.

Two series are now in progress: the FIRST SERIEs, Marine Univalves, of which seventeen volumes have appeared, finishing the series as planned by its illustrious founder. Of the SFcond SERIEs, Terrestrial Molluscs, Ten Volumes have been published, completing Helix with index. A few copies of Vol. IX of this series, "Guide to the Study of Helices" will be sold separately at the regular subscription. price. Separate copies of the Index, suitable for the purposes of a Catalogue or Check list can also be had at $\$ \mathbf{r}, 00$ each.

The Monography of the Bulimi has been commenced in the tenth and eleventh. volumes.

The illustrations of the Manual have received high commendation, and are fully equal to the best figures of shells published.

Prices:-Plain (1111colored) edition $\$ 3.00$ per part. Colored edition $\$ 5.00$ per part. Fine edition (both colored and India-tinted plates) $\$ 8.00$ per part.

Structural and Systematic Conchology, by GEO W. TRYON, Jr.

A CoMpletf. Coxchological TEXT Book of I200 pages, i 40 plates and over 3500 figures of Genera, Anatomy, etc. Three volumes bound in one Cloth. Price $\$ 6.00$.

For further information or descriptive circular, with sample plates of Manual address :

S. RAYMOND ROBER'TS, 'Treasurer,

P. 0. Address, GLEN RIDGE, NEW JERSEY, U. S. A.

A11 Illustrated CATALOGUE OF JAPANESE MARINE MOLLUSKS, by F. Stearns and H. A. Pilsbry. Cloth $\$ 3.00$, paper \$2.50.

\section{WANTED:}

North American species of Amnicola, Lyogyrus, Bythinella and other fresh water Rissoid genera. Will buy or exchange.

\section{BRYANT WALKER,}

18 MOFFAT BUILDING, DETROIT, MICH.

\section{Shells, Marine Curios, \&c. I am now ready to sup-}

low prices and should you wish anything from ply first-class stock at from you. All inquiries will have a prompt reply.

J. H. HOLMES, DUNEDIN, FLA.
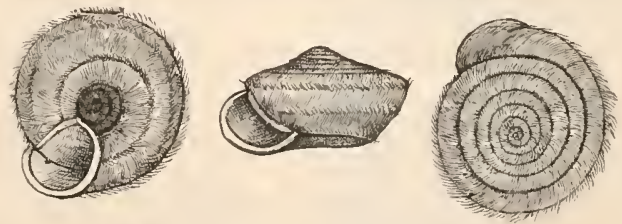

\section{CONCHOLOGY.}

G, B. SOWERBY and HUGH FULTON have the pleasure of informing their clients that they lave joined in partnership uniting their rich and extensive stocks of shells thereby bringing together an assortment unique in its vastness.

Amateurs and Museums either forming collections of Mollusca or desiring to add thereto, can by applying to the above, receive selections on approval at moderate prices.

Collections Purchased. Exchanges made for species not in stock. 


\section{THE}

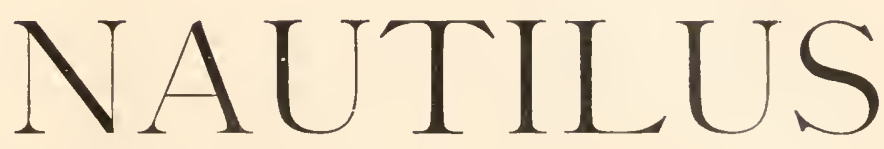

A MON'THLY

DEVOTED TO THE INTERESTS

OF CONCHOLOGISTS.

EDITUR :

H. A. Pilsbry, Conservator Conchological Section, Academy of Natura Sciences, Philadelphia.

ASSOCIATE F.DITOR:

C. W. Johnson, Curator of the Wagner Free Institute of Science.

Vol. XI.

MARCH, 1898.

No. 11

\section{CONTENTS :}

PAGE.

Mollusca Contemporaneous with the Mastodon. By Bryant IValker. 121 Hawailan Cyfraid. By D. D. Baldwin. . . . . . . 123

New Varieties of Unionid A. By Berlin H. Wright. . . . . . 123

Descriptions of New Pisidia. By Dr. V. Sterki. . . . . . 124

Publications Receiveis, . . . . . . . . . . . . 126

A Classified Catalogue of American land Shells, with localities.

(Continued). By Henry A. Pilıtry. . . . . . . 127

Published by

H. A. PILSBRY, Editor, Academy of Nat. Sciences, Philadelphia.

C. WV. JOHNSON, Manager, Wagner Free Institute of Science, Philad'a.

Entered at Philadelphia Post-Office as second-class matter. 


\section{BACK VOLUMES OF THE NAUTILUS.}

Vol. IV. May, 1890 to A pril, 1891, . $\$ 1.00$

Vol. V. May, 1891 to A pril, 1892, - 1.00

Vol. VI. May, 1892 to A pril, 1893, . 1.00

Vol. VII. May, 1893 to April, 1894, . 1.00

Vol. VIII. May, 1894 to April, 1895. . 1.00

Vol. IX. May, 1895 to April, 1896. . 1.00

Vol. X. May, 1896 to April, 1897. 1.00

Of Vols. I and II, which were known as the "Conchologist's $E_{x}$ change," and Tol. III of 'The NAUTruUs, we can furnish odd numbers only.

Extras of August and September number, (1895) containing an Index to the Conchologists' Exchange for binding with the latter, will be furnished at 10 cents per copy.

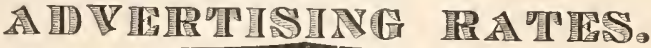

Advertisements will be inserted at the rate of $\$ 1.00$ per inch for each insertion in advance. Smaller space in proportion. A discount of 25 per cent. will be made on insertions of six months or longer. In order to have the paper out promptly, "copy" is put in the printer's hands on the 20th of each month.

\section{Address, C. IV. JOHNSON,} WAGNER FREE INSTITUTE,

Pliladelphia, Pa.

\section{EXCHANGES,}

The following space is to be given to exchanges. Notices not exceeding three lines, will be free to subscribers as long as our limit of space will allow.

For Exchaxge:-Helix latiaxis, Lintere, Tayloriand ; also large collection of land and marine (many rare). Desiderata new or rare Helices. Miss Linter,

Arragon Close, Twickenham Middlesex, England.

For Exchange:-Land, fresh water and marine shells, (many rare species offered) for species not in my collection. List first.

C. F. AnCEY, administrateur-adjoint, Dra-el Mizan, Algeria.

WANTED:-North American Limnaide in sets from various localities. Offered :-Marine shells from Florida and land and fresh water shells from Chicago.

Frank C. BAKER,

Academy of Sciences, Lincoln Park, Chicago, Ill.

OFFERED:-Land, fresh-water and marine shells, many desirable species. Also a few Conchological books.

A. A. Hinkley, D॥ Bois, Ill.

For Exchange:-Austrian shells; also various marine, land and fresh water shells, for species not in my collection. List first.

A. Oberw mmer, Med. III, Haupt St. 97, Vienna, Austria.

OFferen :- Fine sets of Wis. Unios, natural or polished, together with pearls with each, all correctly identified and desirable for scientific collections and nuseums.

Mrs. E. C. Wrswall, 408 Park St., Kenosha, Wis. 


\section{Ward's Natural Science Establishment,}

\section{8-28 College Ave., Rochester, N. Y.}

\section{A SCIENTIFIC EMPORIUM.}

Furnishes yearly to Collectors, Educational Institutions, and Iuseuns throughout the world, many thousand dollars' worth of

INVERTEBRATES

(Shells, Corals, Sponges, Crustaceans, etc.)

SKINS AND SKELETONS OF VERTEBRATES,

MINERALS, ROCKS, FOSSILS.

ANATOMICAL PREPARATIONS, CASTS, MODELS, RELIEF MAPS,

ARCH无OLOGICAL AND ETHNOLOGICAL IMATEIAL, HUMAN SKELETONS, Etc.

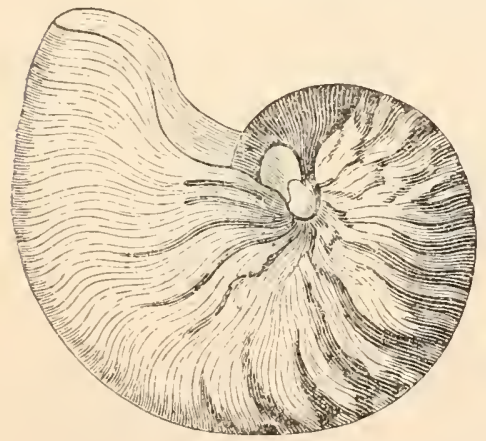

Our Australian Expedition of IS96 lias augmented very considerably our extensive stock of shells, and has compelled the issuance of a new and enlarged edition of our illustrated "Catalogue of Mollusca," now in . press. Watch this space for $110-$ tice of its publication.

For information, circulars, etc., write to

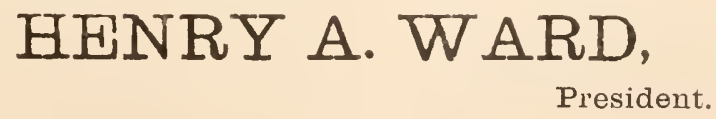




\section{THE MANUAL OF CONCHOLOQY.}

Founded by the late Geo. W. Tryon, Jr., continued under the care of the Conchological Section, Academy of Natural Sciences of Philadelphia, by Henry A. Pilsbry, Conservator.

The Manual of Conchology is a fully illustrated monography of recent mollusks.

Issued in octavo form, in quarterly parts. Fach part comprises 64 (or more) pages of letterpress, and 15 to 20 plates.

Two series a re now in progress: the FIRST SERIES, Marine Univalves, of which seventeen volumes have appeared, finishing the series as planned by its illustrious founder. Of the SF.cond SERIEs, Terrestrial Molluscs, Ten Volumes have been published, completing Helix wth index. A few copies of Vol. IX of this series, "Guide to the Study of Helices" will be sold separately at the regular subscription price. Separate copies of the Index, suitable for the purposes of a Catalogue or Check list can also be had at \$I.0o each.

The Monography of the Bulimi has been commenced in the tenth and eleventh volumes.

The illustrations of the Manual have received high commendation, and are fully equal to the best figures of shells published.

Prices:- Plain (uncolored) edition $\$ 3.00$ per part. Colored editiou $\$ 5.00$ per part. Fine edition (botll colored and India-tinted plates) $\$ 8.00$ per part.

Structural and Systematic Conchology, by GEO W. TRION, Jr.

A COMPLETF. CONCHOLOGICAL TEXT BOOK of I 200 pages, I40 plates and over 3500 figures of Genera, Anatony, etc. Three volumes bound in one Cloth. Price $\$ 6.00$.

For further information or descriptive circular, with sample plates of Manual address

\section{S. RAYMOND ROBERTS, 'Treasurer,} P. 0. Address, GLEN RIDGE, NEW JERSEY, U. S. A. An Illustrated CATALOGUE OF JAPANESE MARINE MOLLUSKS, by $F$. Stearns and H. A. Pilsbry. Cloth $\$ 3.00$, paper $\$ 2.50$.

\section{WANTED:}

North American species of Amnicola, Lyogyrus, Bythinella and other fresh water Rissoid genera. IVill buy or exchange.

\section{BRYANT WALKER,}

18 MOFFAT BUILDING, DETROIT, MICH.

\section{Shells, Marine Curios, \&c. I am now ready to sup-} low prices and should you wish anything from this first-class stock at from you. All inquiries will have a prompt reply.

\section{J. H. HOLMES, DUNEDIN, FLA.}
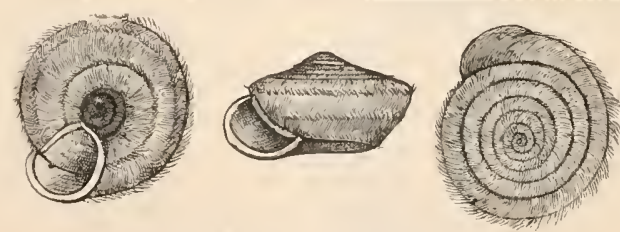

\section{CONCHOLOGY.}

G. B. SOWERBY and HUGH FULTON have the pleasure of informing their clients that they have joined in partnership uniting their rich and extensive stocks of shells thereby bringing together an assortment unique in its vastness.

Amateurs and Museums either forming collections of Mollusca or desiring to add thereto, can by applying to the above, receive selections on approval at moderate prices.

Collections Purchased. Exchanges made for species not in stock. 


\section{THE}

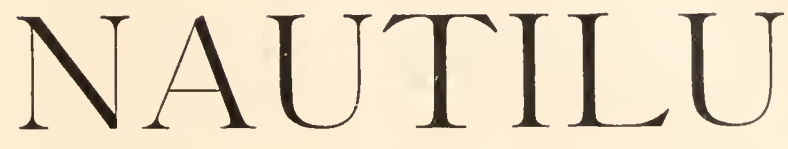

A MONTHLY

DEVO'TED 'TO THE INTERESTS

OF CONCHOLOGISTS.

EDITUR :

H. A. Prlsary, Conservator Conchological Section, Academy of Natura! Sciences, Philadelphia.

ASSOCIATE EDITOR :

C. W. Johnson, Curator of the Wagner Free Institute of Science.

Vol. XI.

APRIL, 1898.

No. 12

\section{CONTENTS:}

PAGE.

Descriptinns of New American Land Shells. By Henry A. Pilsbry. . 133

A New Subgenus of Coral.tophaga. By W. H. Dall. . • . . 135

Notes and News. . . . . . . . . . . . . . . . . 135

Recent Publications. . . . . . . . . . . . . . 137

A Classified Catalogue of American Land Sheils, with Localities.

(Concluded). By Henry A. Pilsbry. . . . . . . 138

\section{Published by}

H. A. PILSBRY, Editor, Academy of Nat. Sciences, Philadelphia.

C. W. JOHNSON, Manager, Wagner Free Institute of Science, Philad'a.

Entered at Philadelphia Post-Office as second-class matter. 


\section{A New Catalogue of North American Land Shells}

A revised reprint of the Catalogue published in The Nauturus

from August, 1897 to April, 1898. Giving the geographic

distribution, most recent synonymy, varieties and

classification of all species known to

inhabit America north of

Mexico.

35 pages, in paper cover.

PRICE 25 CTS.

\section{NAUTILUS ADVERTISING RATES}

Advertisements will be inserted at the rate of $\$ 1.00$ per inch for each insertion in advance. Smaller space in proportion. A discount of 25 per cent. will be made on insertions of six months or longer. In order to have the paper out promptiy, "copy" is put in the printer's hands on the 20th of each month.

\section{Address, C. IV. JOHNSON,}

Wagner Free Institute, Philadelphia, Pa.

\section{LAND AND MARINE SHELLS.}

A special collection from the high mountains ? FIRST CLASS in Java, Lombok and Celebes. $\}$ SPECIMENS ONLY.

PRICES MODEIRA'TE.

PRICE-LIST FREE ON APPLICATION.

H. FRUHSTORFER, Thurm=Strasse 37, Berlin, N. W.

\section{EXCHANGES,}

The following space is to be given to exchanges. Notices not exceeding three lines, will be free to subscribers as long as our limit of space will allow.

For Exchaxge:-Land, fresh water and marine shells, (many rare species offered) for species not in my collection. List first.

C. F. Axcer, administrateur-adjoint, Dra-el Mizan, Algeria.

OFFERED:-Land, fresh-water and marine shells, many desirable species. Also a few Conchological books.
A. A. Hinkley, Du Bois, Ill.

For Exchange:-Austrian shells; also various marine, land and fresh water shells, for species not in my collection. List first.

A. Oberwimer, Med. III, Haupt St. 97, Vienna, Austria.

For Exchange:-Cyprceas for Cyprceas, send list to

Mrs. S. L. Willians, 593 Jackson Boulevard, Chicago, Ill.

OFFERED :-Tertiary and recent land and fresh-water shells of France. TV ANTED :-Tertiary and recent shells of North America. Andre bonnet, 55 Boulevard St., Michel, Paris, France. 


\section{The Chambered Nautilus.}

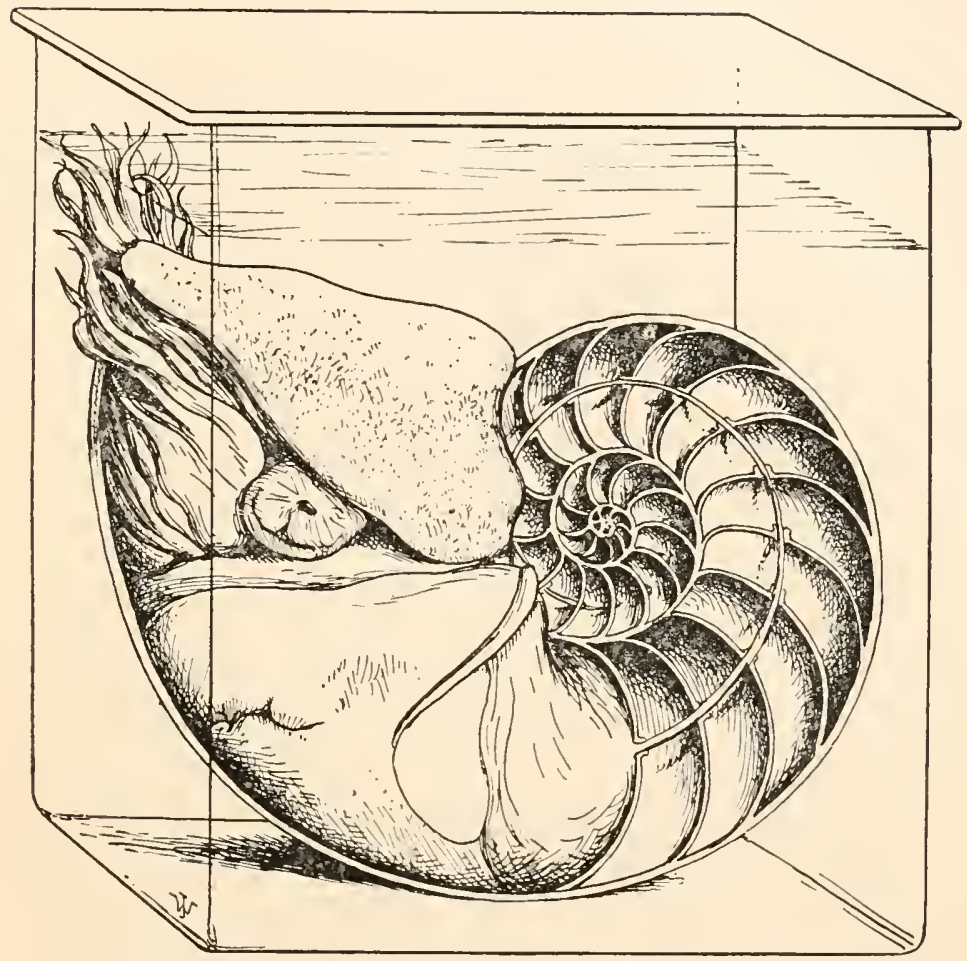

NAUTILUS POMPILIUS, Linn. Western Polynesia.

Specimens in alcohol of this rare animal, with shell bisected,

mounted in glass jar, as shown above, . . . . . \$12.00

Sent moist without jar . . . . . . . . . . . . . 10.00

Non-bisected . . . . . . . . . . . 1000

Non-bisected, without jar . . . . . . . . . 8.00 Small-sized, $\$ 3.00$ less than above.

Write for special circular to

\section{Warr's Matural Science Establishment,}

18 to 8 COLLEGE AVE., ROCHESTER, N. Y.

Watch this page for notice of publication of our new Shell Catalogue. 


\section{THE MANUAL OF CONCHOLOQY.}

Founded by the late Geo. W. Tryon, Jr., continued under the care of the Con. chological Section, Academy of Natural Sciences of Philadelphia, by Henry A. Pilsbry, Conservator.

The Manual of Conchology is a fully illustrated monography of recent mollusks.

Issued in octavo form, in quarterly parts. Each part comprises 64 (or more) pages of letterpress, and 15 to 20 plates.

Two series are 110 in progress: the FIRst SERIEs, Marine Univalves, of which seventeen volumes have appeared, fillishing the series as planned by its illustrious founder. Of the SFCOND SERIEs, Terrestrial Molluscs, Ten Volumes have been published, completing Helix with index. A few copies of Vol. IX of this series, "Guide to the Study of Helices" will be sold separately at the regular subscription price. Separate copies of the Index, suitable for the purposes of a Catalogue or Check list can also be had at $\$ r . \infty$ each.

The Mouography of the Bulimi has been commenced in the tenth and eleventh voluines.

The illustrations of the Manual have received high commendation, and are fully equal to the best figures of shells published.

Prices:-Plain (11110olored) edition $\$ 3.00$ per part. Colored edition $\$ 5.00$ per part. Fine edition (both colored and India-tinted plates) $\$ 8.00$ per part.

Structural and Systematic Conchology, by GEO W. TRYON, Jr.

A COMPLETE CONCHOLOGICAL TEXT BOOK of 1200 pages, 140 plates and over 3500 figures of Genera, Anatomy, etc. Three volumes bound in one Cloth. Price $\$ 6.00$.

For further information or descriptive circular, with sample plates of Manual addiess :

\section{S. RAYHOND ROBER'TS, Treasurer, P. 0. Address, GLEN RIDGE, NEW JERSEY, U. S. A.} A11 Illustrated CATALOGUE OF JAPANESE MARINE MOLLUSKS, by F. Stearns and II. A. Pilsbry. Cloth $\$ 3.00$, paper $\$ 2.5 \circ$.

\section{CHOICE SHELLS.}

Some collectors are satisfied with "any old thing" in order to fill out the varieties in their collection. We furnish choice, showy, bright colored, polished, perfect specimens at reasonable prices. Sea Shells fron all parts of the world. Ask for illustrated list. Correspondence solicited from foreign collectors also.

IOWA SEED CO., DES MOINES. IOWA.

\section{Shells, Marine Curios, \&c. I ann now ready to sup-} low prices and sloould you wish anything from this section, let me hear from you. All inquiries will liave a prompt reply.

\section{J. H. HOLMES, DUNEDIN, FLA.}
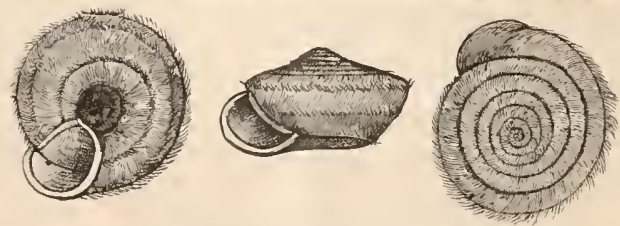

\section{CONCHOLOGY.}

G. B. SOWERBY and HUGH FULTON have the pleasure of informing their clients that they have joined in partnership mniting their rich and extensive stocks of shells thereby bringing together an assortment unique in its vastness.

Amateurs and Museums either forming collections of Mollusca or desiring to add thereto, can by applying to the above, receive selections on approval at moderate prices.

Collections Purchased. Exchanges made for species not in stock.

SOWERBY \& FULTON, 


MBL/WHOI LIBRARY

- int

WH $\mathrm{H}$ ? $\mathrm{KH}$ 
